\title{
THE DOOR BEHIND THE BAMBOO CURTAIN - CHINESE LAW AND POLICY ON REFUGEE STATUS
}

BY

\section{LILI SONG}

\begin{abstract}
A thesis
submitted to the Victoria University of Wellington in fulfilment of the requirements for the degree of Doctor of Philosophy
\end{abstract}

Victoria University of Wellington (2014) 


\begin{abstract}
This thesis systematically considers the law and policy on refugee status in the People's Republic of China. It considers relevant Chinese legal provisions, applicable bilateral and multinational treaties, as well as China's refugee policy and practice. It also presents and analyses first-hand information collected through interviews with refugees and aid workers.

China is an emerging destination of refugees and other displaced foreigners. Although China is a party to the 1951 Convention relating to the Status of Refugees and its 1967 Protocol, Chinese law contains no provisions governing the definition of a refugee or the determination of refugee status. Further, there is a gap between the criteria for asylum in the 1982 Chinese Constitution and the criteria for refugee status in the 1951 Convention.

In practice, although the Chinese government has generally allowed the United Nations High Commissioner for Refugees to process individual applications for refugee status, the Chinese government has practically performed the function of refugee status determination in large-scale influx situations through policy decisions. In these situations, the security, political, and strategic interests of China have often overshadowed China's commitment under the 1951 Convention.

China has been cautious about recognising refugees on its territory. However, the Chinese government has clearly demonstrated a growing interest in addressing the issue of refugee recognition within a more formalised framework.

In conclusion, this thesis recommends that China adopt a legal refugee definition in line with the 1951 Convention relating to the Status of Refugees and develop a predictable and fair national RSD mechanism.
\end{abstract}




\section{Preface}

I believe this thesis is incomplete without mentioning my trip to North Korea seven years ago. In 2007, I applied for my very first passport at the Shanghai Exit-Entry Administration Bureau in order to travel abroad for the first time in my life. The destination was North Korea.

I spent four days in North Korea. On my last day in North Korea, there was a power cut in Pyongyang. It happened just after dinner, when I was still in the restaurant at my hotel. As the hotel had only a few torches for guests, I had to walk to my room on the $10^{\text {th }}$ floor in the dark. I could have used my cell phone to light my way, if foreigners were allowed to travel with cell phones in North Korea. But it was not the case.

As I walked up the stairs, a North Korean man came down from upstairs with a lighter in his hand. We passed each other silently. I had learned quickly in North Korea that initiating a conversation with ordinary North Koreans may cause them trouble later. I continued walking, and then noticed that the man had stopped. He was standing at where we just passed each other, holding his lighter. I realised that he wanted to share the light from his lighter with me for a longer while. I still remember vividly that tiny, steady light in the darkness of Pyongyang.

I left Pyongyang at midnight on a slow train to China. I looked through the darkness outside the window of the train and thought of the North Korean escapees whom I read about in Chinese newspapers. Many of them might have made their way to the Chinese border in the same intimidating darkness in the hope of finding a better world on the other side of the border. Most of them ended up illegally hiding in China or being returned to North Korea, as North Korean escapees have been regarded as illegal economic migrants by China. I could not help comparing them to the Indochinese who fled to my native Guangxi Zhuang Autonomous Region in South China in the late 1970s and the early 1980s. The Indochinese were recognised as refugees and stayed to build a new life in China. The huge difference between their fates made me wonder: who is a refugee in China?

I knew there would be no easy answer to this question, but I was sure that it was a question that I did not want to leave unanswered. This thesis is my humble effort to do something in return for the man who shared the tiny, steady light in the darkness, and for all the ordinary North Koreans I met, who inspired me to never give up hope, love for life, and belief. 


\section{Table of Contents}

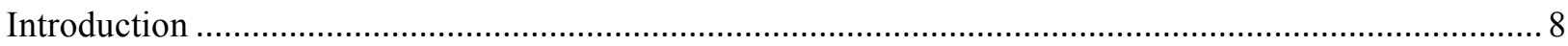

Chapter I Refugees and Other Displaced Foreigners in China …........................................................ 14

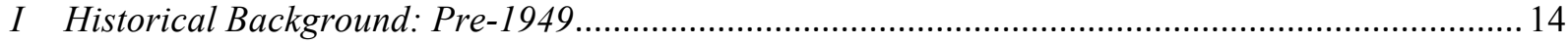

II Refugees and Other Displaced Foreigners in China: 1949-1982 ............................................ 15

III Refugees and Other Displaced Foreigners in China: 1983-2013 ..........................................2 21

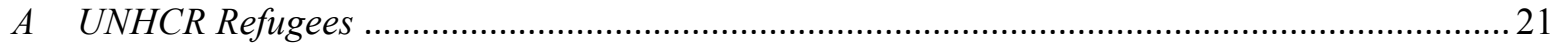

$B \quad$ Refugees and Other Displaced Foreigners Dealt with by the Chinese Government...................24

IV Refugees and Other Displaced Foreigners and Chinese Civil Society .......................................2 28

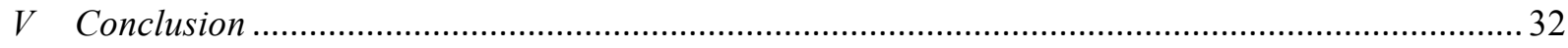

Chapter II The Refugee Concept under International law ................................................................. 34

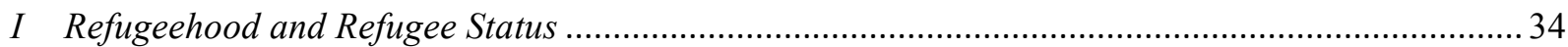

II The Definition of a Refugee under the 1951 Convention relating to the Status of Refugees and its

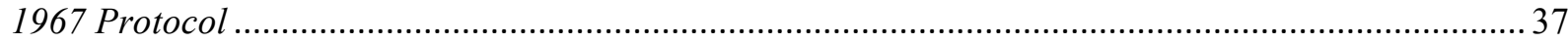

A The 1951 Convention relating to the Status of Refugees and its 1967 Protocol ............................37

1 Status of the 1951 Convention relating to the Status of Refugees and its 1967 Protocol .........37

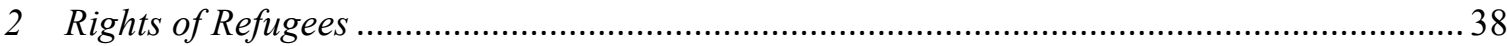

3 Limitations of the 1951 Convention relating to the Status of Refugees and its 1967 Protocol 39

$B \quad$ The Definition of a Refugee under the 1951 Convention relating to the Status of Refugees and

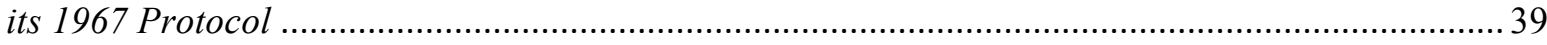

C Interpretation and Application of the Convention Refugee Definition ....................................... 40

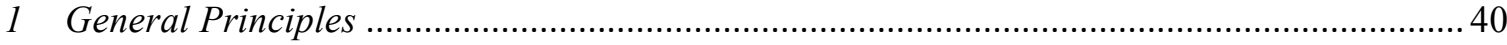

2 Application of the Convention Refugee Definition in Mass Influx Situations .............................42

3 People Fleeing Armed Conflict and the Situation of Displaced Ethnic Kokangs and Kachins

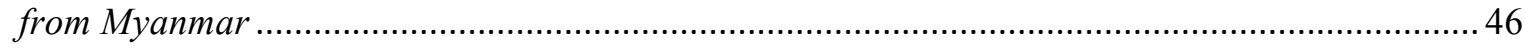

4 Refugee sur Place and the Situation of North Korean Escapees ...............................................49

5 Dual Nationality and the Situation of North Korean Escapees ............................................... 51

D China's Accession to the Convention and Protocol .................................................................56

III Refugees for the Purposes of the United Nations .........................................................................5 57

A United Nations High Commissioner for Refugees ....................................................................5

$B \quad$ Refugees for the Purposes of the United Nations and Expansion of UNHCR Mandates ............58

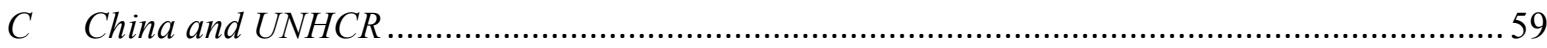

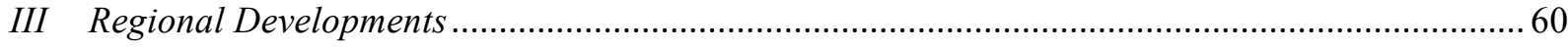

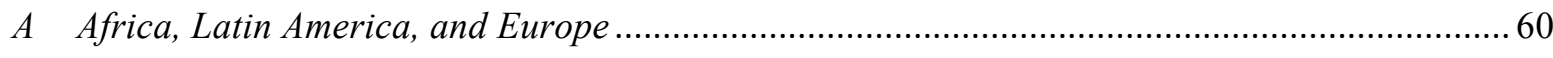

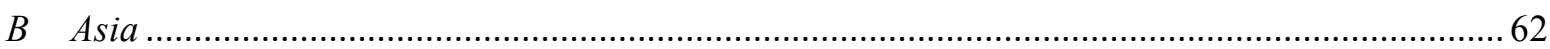


1 The Bangkok Principles by the Asian-African Legal Consultative Organization.

2 The Asia-Pacific Consultations and the Bali Process

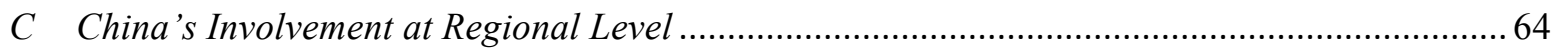

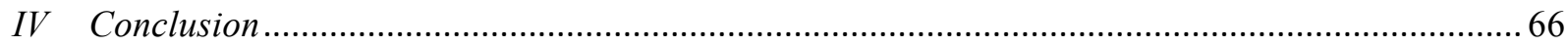

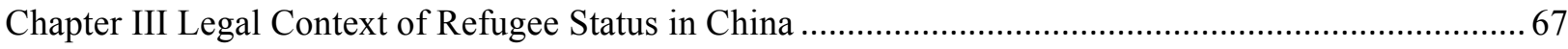

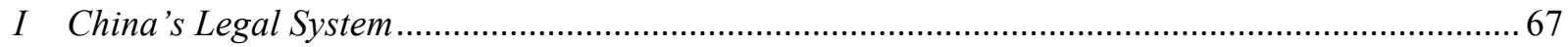

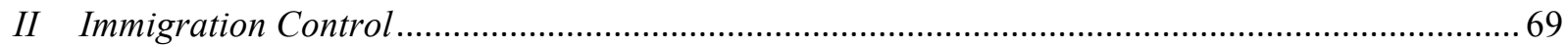

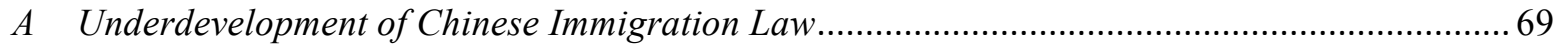

B General Provisions of the 2012 Exit and Entry Administration Law .......................................... 69

C Criminalisation of Unauthorised Departure and Entry under the 1997 Criminal Law.............. 70

III Existing Legal Provisions relating to Refugees and Asylum ..................................................... 71

A Article 32(2) of the 1982 Constitution ………....................................................................... 71

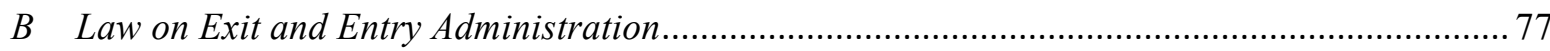

$C \quad$ Emergency Response Plans on Sudden Incidents Involving Foreign Factors ............................ 79

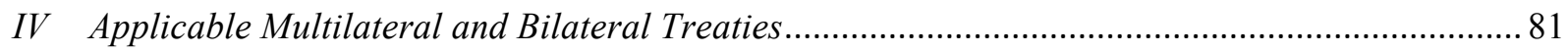

A The Convention and Protocol relating to the Status of Refugees ............................................. 81

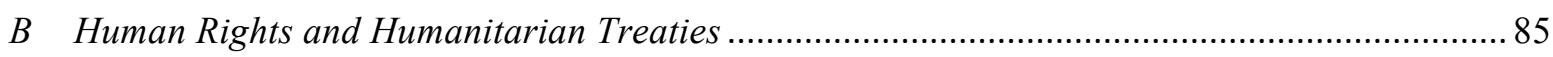

C Protocol on Cooperation in the Work of Maintaining National Security and Social Orders at Border Areas between China and North Korea ............................................................................ 87

D Protocol on Chinese-Myanmar Border Management and Cooperation ..................................... 90

E Protocol on the Repatriation of Lao Refugees between China and Laos .................................. 93

$V \quad$ Refugee Law and Procedures in Macau and Hong Kong ......................................................... 93

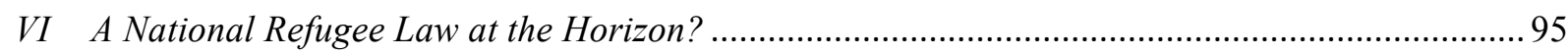

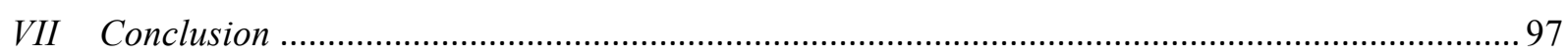

Chapter IV China's Refugee Policy and Practice ................................................................................ 98

I The Beginning of China's Refugee Policy: the Indochinese Refugee Crisis and Its Impact ............ 98

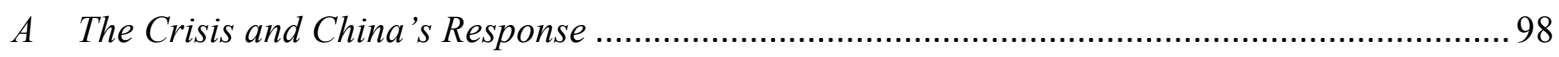

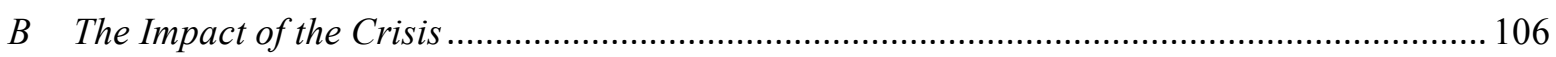

II Developments: From North Korean Influx to Kokang Incident to Kachin Influx ......................... 109

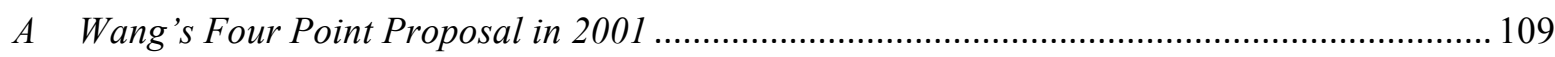

B Controversial Repatriation of the North Korean Escapees ................................................. 110

1 China's Policy on the North Korean Escapees ............................................................... 110

2 Political and Security Consideration Underlying China's Policy on the North Korean

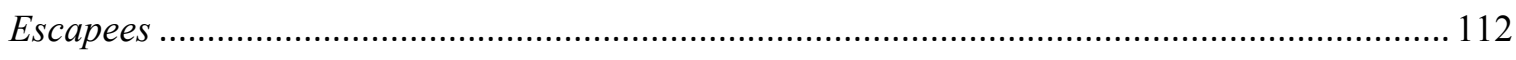

3 The Contrast between the North Korean Escapees and the Indochinese Refugees ............... 113

4 The Importance of Meaningful Protection .......................................................................... 113 
C An Ambiguous Welcome: The Kokang Incident.

1 China's Response to the Kokang Incident.

2 Possible Legal Grounds and Political Motivations.

3 Common Characteristics between the Displaced Kokangs and the Indochinese Refugees ... 116

D Where is China's Refugee Policy Going: the Kachin Influx.....

1 China's Response to the Kachin Influx

2 Similarities and Differences between the Displaced Kokangs and Kachins

III Conclusion.

Chapter V Procedures and Institutional Framework

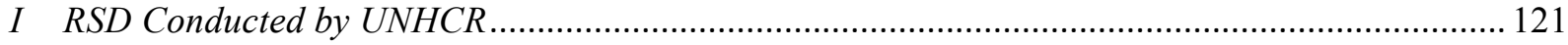

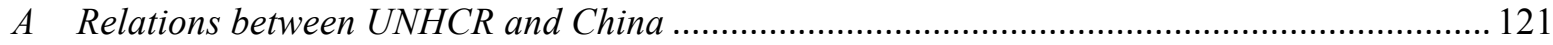

B Refugee Status Determination Conducted by the UNHCR Beijing Office ................................. 124

II Refugee Status Determination Conducted by the Chinese Government ...................................... 125

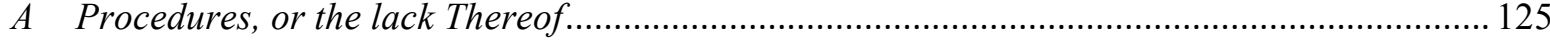

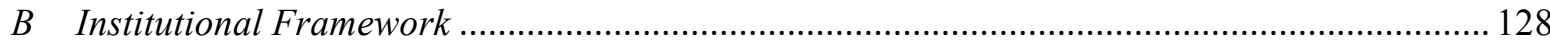

1 Ministry of Civil Affairs and Offices of Reception and Settlement of Indochinese Refugees. 128

2 Ministry of Foreign Affairs.

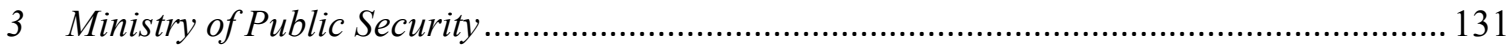

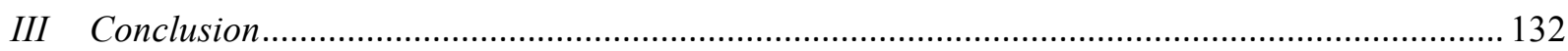

Chapter VI Reality at the Border and Voices from Refugees and Humanitarian Workers...................... 133

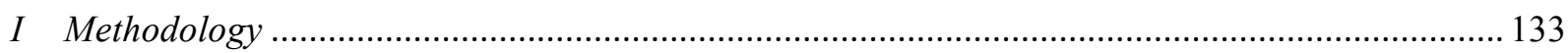

II Reality at the Chinese-Myanmar Border: Nabang/Laiza and Zhangfeng/Mai Ja Yang ............... 137

III Voices from Refugees and Humanitarian Workers................................................................. 140

A Absence of Assessment of Individual Situations ................................................................... 140

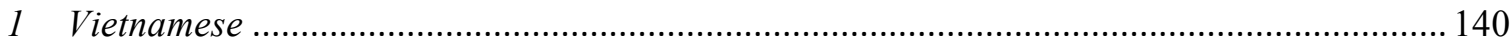

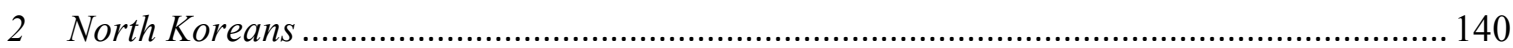

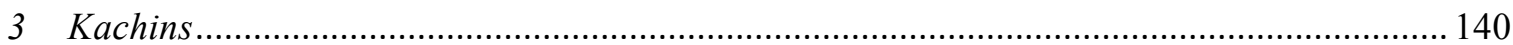

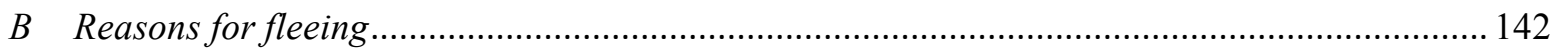

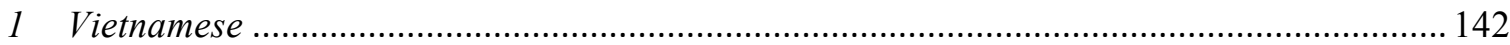

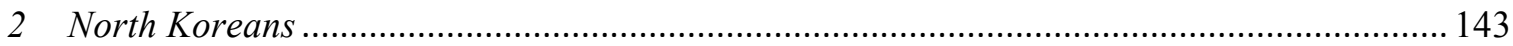

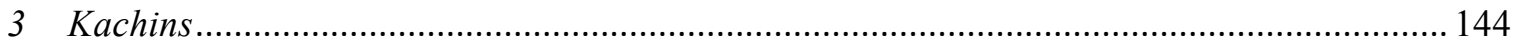

C Unavailability of Refugee Status Determination Services for North Koreans and Kachins ..... 144

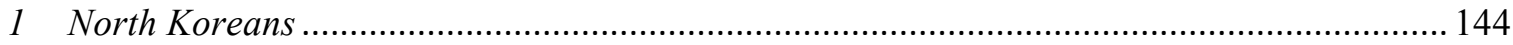

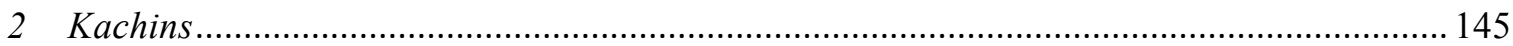

D Legal Basis for China's Treatment of Displaced Kachins .................................................... 147

E Lack of Assistance from Chinese Authorities ..................................................................... 150 


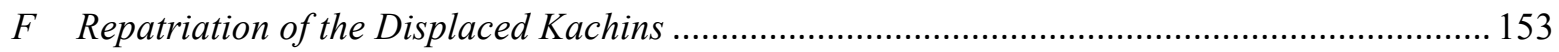

G Blurred Identity of Indochinese Refugees in China ............................................................. 155

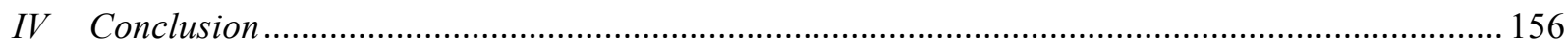

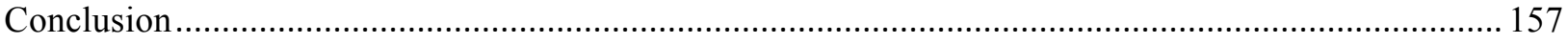

I Chinese Refugee Law and Policy at a Crossroad .................................................................. 157

II Towards a Predictable and Fair National Mechanism.......................................................... 158

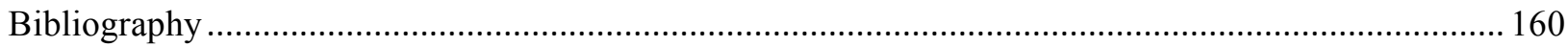




\section{Index of Maps and Charts}

Map 1 Map of China and its Neighbours

Map 2 Administrative Map of China

Map 3 Administrative Map of Myanmar

Chart 1 Timeline of Key Events in China Mentioned in this Thesis 1949-2014

Chart 2 Numbers of UNHCR Refugees and Asylum Seekers in China 2000-2014

Chart 3 Demographic Composition of Populations of Concern to UNHCR in China in $2012 \quad 23$

Chart 4 What do you Think of Refugees? 30

Chart 5 What do you Think of Illegal Border Crossers? 30

Chart 6 Trigger Level of Refugee Numbers in Local Emergency Response Plans 81

Chart 7 Designated Border Towns on Chinese-Myanmar Border under Appendix I of the ChinaMyanmar Bilateral Protocol 
List of Abbreviations

AALCO Asian-African Legal Consultative Organization

APC Inter-Governmental Asia-Pacific Consultations on Refugees, Displaced Persons and Migrants

BEEA Bureau of Exit and Entry Administration in China

BCD Border Control Department in China

ECOSOC United Nations Economic and Social Council

HRW Human Rights Watch

IOM International Organization for Migration

IRO International Refugee Organisation

KIO Kachin Independence Organisation

KIA Kachin Independence Army

MFA Ministry of Foreign Affairs of China

MOF Ministry of Finance of China

MPS Ministry of Public Security of China

MCA Ministry of Civil Affairs of China

OAU Organisation of African Unity

OCAO Overseas Chinese Affair Office of China

OCF Overseas Chinese Farm in China

ORSIR Office for the Reception and Settlement of Indochinese Refugees in China

PSB Public Security Bureau in China

SCIO State Council Infornation of Office in China

RSD Refugee Status Determination

UN United Nations

UNCEDW United Nations Committee on the Elimination of Discrimination against Women

UNHCR United Nations High Commissioner for Refugees 


\title{
Introduction
}

\author{
One refugee without hope is too many. \\ - United Nations High Commissioner for Refugees ${ }^{1}$
}

The rise of China as an emerging world power in the past few decades has led to significant changes to the landscape of migration in the country. Founded in 1949 with a communist government, the People's Republic of China has not been a popular destination for foreign visitors until very recently. In 1980, only 740,000 foreigners entered China; the figure was 27 million in 2011, more than 36 times the 1980 figure. ${ }^{2}$ Alongside the rising tide of regular and legal immigrants to China have come undocumented and irregular immigrants. In 2011, more than 20,000 foreigners were found illegally entering, staying or working in China. ${ }^{3}$

A significant proportion of the irregular immigrants entering China are refugees, asylum seekers, and other displaced foreigners. Traditionally, China is a source rather than destination of refugees, however, China has witnessed a rapid growth in the number of persons seeking refuge on its territory in the past 20 years. There have been several large scale inflows of displaced foreigners from neighbouring countries into China in the past two decades. Since the mid-1990s, large numbers of North Koreans have continued to cross into China illegally. In 2009, more than 30,000 displaced ethnic Kokangs from Myanmar flooded into China's Yunnan Province on the Chinese-Myanmar border. In 2011 and 2012, more than 7,000 displaced ethnic Kachins from Myanmar escaped to China's Yunnan Province. In addition, the number of individual asylum seekers and refugees, who came from as close as neighbouring Pakistan and as far as Mali in West Africa, has also been on the rise in recent years.

China borders several of the most politically and economically problematic nations in the world (see Map 1). China has land borders with 14 countries. According to the Fund for Peace's Failed States Index 2013, five of China's neighbouring countries, namely Afghanistan, North Korea, Pakistan, Myanmar, and Nepal, fall within the "Alert" category, which means these countries have the highest vulnerability to collapse or conflicts among the 177 countries assessed in the index. ${ }^{4}$ China's future exposure to refugee issues should not be underestimated.

\footnotetext{
${ }^{1}$ This was United Nations High Commissioner for Refugees (UNHCR)'s main message to the public in 2012 which marked the $60^{\text {th }}$ year of the 1952 Convention relating to the Status of Refugees (the Convention).

2 "xinshiji yilai waiguoren rujing renshu meinian dizeng 10\% [Number of Foreigners Entering China Increases 10 Per Cent Each Year Since Year 2000]" (25 April 2012) Xinhua <http://news.xinhuanet.com/legal/201204/25/c_111842921.htm> (accessed 20 February 2014).

3 "shewai jiazheng, waiguoren feifa jiuye duofa [Foreigners Frequently Found Illegally Working as Housemaids]" (26 April 2012) Xinhua <http://www.npc.gov.cn/huiyi/cwh/1126/2012-04/26/content_1719376.htm> (accessed 28 April 2014).

${ }^{4}$ The 2013 Fund for Peace Failed States Index ranks 177 countries in terms of their volnerability to collapse or conflict. Countries in the "Alert" category have the highest vulnerability. The 2013 Fund for Peace Failed States Index is available at Fund for Peace <http://ffp.statesindex.org/rankings-2013-sortable > (accessed 10 March 2014).
} 


\section{Map 1 Map of China and its Neighbours}

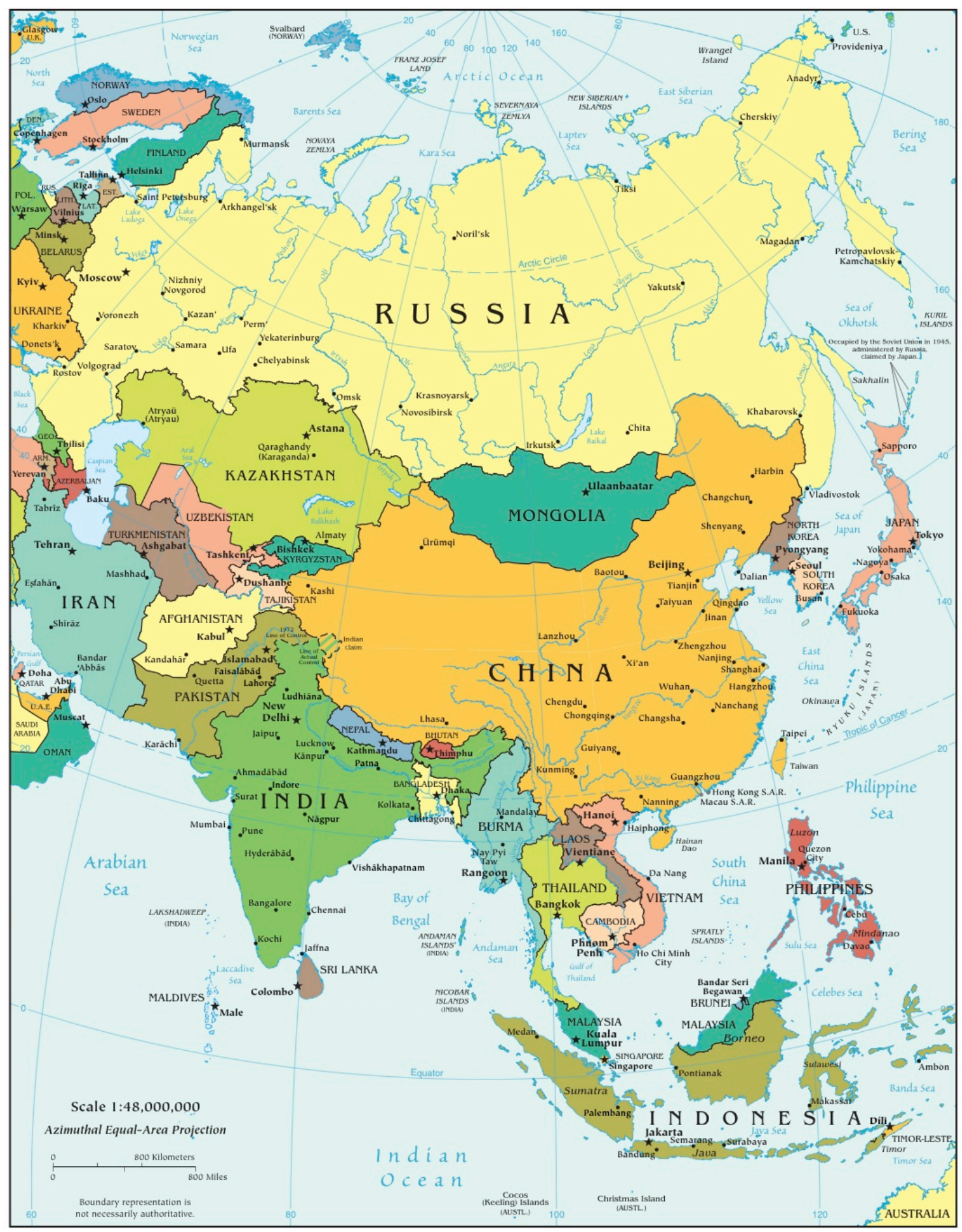

Source: the United States Central Intelligence Agency, available at Perry-Castañeda Library Map Collection, the University of Texas at Austin <http://www.lib.utexas.edu/maps/middle_east_and_asia/asia_pol_2012.pdf $>$ (accessed 16 April 2014). 
China's refugee problem is tangled with some of the most politically and strategically sensitive issues in the Asia-Pacific region. For example, China is the most used and most accessible route for North Koreans escaping their country, a dictatorship and a long term ally of China. The exodus of North Koreans is believed to have the potential to lead to the collapse of North Korea, exposing China directly to the United States forces stationed in South Korea. Cross-border displacement from Myanmar to China is deeply intertwined with Myanmar's longstanding ethnic problem, for which no easy solution is in sight. The Chinese-Myanmar border area is one of the world's largest opium and heroin producing regions, where firearms have long been part of local life. Both sides of the Chinese-Myanmar border are predominantly inhabited by ethnic minority groups.

As China's economic strength and political influence continue to grow, how China defines a refugee will not only affect the life and hope of many displaced persons who are forced to flee their home, but also significantly impact the security and stability of the Asia-Pacific region.

For years, few people have bothered asking the question of who is a refugee in China. On the one hand, China's refugee law and policy have largely escaped international attention, despite the fact that China was one of the first Asian States to accede to the 1952 Convention relating to the Status of Refugees (the Convention) and its 1967 Protocol (the Protocol) (collectively the Convention and Protocol) and has been hosting approximately 300,000 Indochinese refugees since 1978. ${ }^{5}$ It was not until China's repatriation of North Korean escapees stirred up controversy in the international community that interest in China's refugee law and policy began to emerge in the late 1990 s.

On the other hand, interest in refugee issues is just awakening within China. Unlike immigration countries like Australia, Canada, and New Zealand, where migration is an essential experience of their nationals and where refugee issues are well-debated important political and social issues, the refugee issue has not been a priority on the political agenda or at the centre of public attention in China. Except for the Indochinese refugees, the number of refugees and asylum seekers received by China had remained very low until the mid-1990s. Additionally, the Chinese government has treated refugees as a highly sensitive issue. There have been few publications or discussions about refugees or the refugee protection system in China. Systematic research on refugee law and policy did not exist in China until very recently. For example, the first book on international refugee law written in Chinese was published only in $2009 .^{6}$

The pressing issue of North Korean escapees and the frequent large-scale influxes of displaced ethnic minorities from Myanmar in the past few years have brought the Chinese government and Chinese scholars to look at refugee issues. Additionally, thanks to the media coverage of the high profile case of Edward Snowden, the United States whistleblower who fled to China's Hong Kong Special Administrative Region in June 2013 and who was rumoured to have

\footnotetext{
${ }^{5}$ China is the second largest host country for Indochinese refugees.

${ }^{6}$ Liang Shuying's book International Refugee Law, which was published in 2009, was referred to "the first of its kind in China" by Veerapong Vongvarotai, then UNHCR Regional Representative for China \& Mongolia, in his foreword for the book.
} 
approached Beijing for asylum, ${ }^{7}$ refugee issues have started to come to the attention of the Chinese society.

However, China's definition of a refugee has remained behind the "bamboo curtain". Although China acceded to the Convention and Protocol in 1982, it has not enacted any national law to incorporate the provisions of the Convention and Protocol. China does not have a refugee law, and domestic Chinese law contains no provisions governing refugee definition or refugee status determination (RSD). China's policy and practice in interpretation and application of the refugee definition provided under the Convention and Protocol have never been closely scrutinised or systematically considered.

Against this background, this thesis examines China's definition of a refugee and the existing refugee status determination procedures in China and makes recommendations on China's future refugee definition. This thesis contains six chapters in addition to Introduction and Conclusion.

Chapter I provides the historical and social background of China's law and policy on refugee status. First, this chapter pieces together China's experience with refugees and other displaced foreigners from the early 1900 s to the early $21^{\text {st }}$ century, demonstrating that the Communist government of China had dealt with very few asylum cases before the mid-1990s and that China has been increasingly challenged by refugee issues in recent years. Second, it analyses the relations between Chinese society and refugees, highlighting that Chinese society in general has little information about or interaction with refugees.

Chapter II explains the concept of a refugee in the international refugee protection regime. This chapter focuses on the refugee definition under the Convention and Protocol (Convention Refugee Definition) and the impact of the practice of the United Nations High Commissioner for Refugees (UNHCR) and regional arrangements on the refugee concept under international law. This chapter also looks at China's involvement in the international refugee protection regime.

Chapter III discusses the Chinese laws applicable to refugee status as well as the implementation of relevant multilateral and bilateral treaties in China. First, this chapter compares relevant Chinese legal provisions with the Convention Refugee Definition. Second, it considers China's implementation of the Convention and Protocol. Third, it explores the role of certain bilateral treaties in China's refugee policy.

Chapter IV undertakes an analysis of China's policy on refugee status since 1949, focusing on China's differing treatment of the Indochinese refugees, the North Korean escapees, and the displaced ethnic minorities from Myanmar. This chapter argues that China's treatment of displaced foreigners, varying from granting refugee status to providing humanitarian assistance without granting refugee status to denial of refugee status and forced repatriation, has mainly depended on its political and strategic interests.

Chapter V looks at the existing RSD procedures in China and the institutions involved in the procedures. First, it introduces the role of UNHCR in China and the RSD services provided by

\footnotetext{
"Edward Snowden 'Broadens Asylum Requests' - Wikileaks" (2 July 2013) BBC $<$ http://www.bbc.com/news/world-europe-23139980> (accessed 28 April 2014).
} 
UNHCR. Second, it examines the Chinese government's decision-making procedures regarding the status of certain groups of displaced foreigners, to whom UNHCR generally has not had access. This chapter points out that China has not established a national mechanism or guideline for fair assessment of the status of displaced foreigners.

Chapter VI is based on my field work in China, Myanmar, and South Korea from 21 March to 30 April 2013. First, this chapter describes my border-crossing experience at two border towns in Yunnan Province, China, which illustrates the immigration control measures implemented by Chinese authorities on the Chinese-Myanmar border, providing a background for understanding the mode of cross-border movement of the displaced minorities from Myanmar. Second, this chapter presents the accounts of refugees and humanitarian workers working with refugees in terms of the interaction between refugees and Chinese authorities.

In conclusion, this thesis recommends that China adopt a legal refugee definition which meets the minimum standard of the Convention and Protocol and develop a predictable and fair national mechanism for RSD.

For the purposes of this thesis, unless otherwise expressed or implied by the context, China refers to the People's Republic of China mainland, excluding the Hong Kong Special Administrative Region (Hong Kong), Macau Special Administrative Region (Macau), and Taiwan.

Many of the Chinese legal and policy documents mentioned in this thesis do not have an official English translation. Unless otherwise stated or indicated by the context, all translation is mine. 
Chart 1 Timeline of Key Events in China Mentioned in this Thesis 1949-2014

1971: representation of the state of China at the United Nations transferred to the People's Republic of China from Republic of China.

1980: UNHCR established an office in Beijing.

Mid-1990s: 1) the number of individual asylum seekers dealt with by UNHCR started to increase; 2) large numbers of North Korean escapees began to arrive in China.

2011: ethnic Kachins from Myanmar fled to China.

2013: the Exit-Entry Law entered into force.
1949: the People's Republic of China was founded.

1978: 1) Indochinese refugee influx started in April; 2) China began to reform and open up.

1982: 1) China acceded to the 1951 Convention relating to the Status of Refugees and its 1967 Protocol; 2) the 1982 Constitution was promulgated.

2009: ethnic Kokangs from Myanmar fled to China.

2012: 1) China repatriated about 5,000 displaced Kachins; 2) the Exit-Entry Law was promulgated. 


\section{Chapter I Refugees and Other Displaced Foreigners in China}

Those who are not of our kind must have a different mind.

- Chinese proverb

\section{Historical Background: Pre-1949}

Displaced aliens are not an unheard-of phenomenon in contemporary Chinese history. During the First World War, more than 300,000 ethnic Kazakhs, Uzbeks, Kyrgyzs, and Russians fled from Tsarist Russia to Xinjiang in Northwest China to escape military service or oppression of dissenters by the government. ${ }^{8}$ Following the Russian Revolution of 1917 , tens of thousands of Russian exiles made their way to China, living mainly in Manchuria and Xinjiang. By mid-1924, about 60,000 Russian exiles were in China. ${ }^{9}$ Throughout the 1920s and in the early 1930s, escapees from Russia continued to arrive in China for both political and economic reasons. ${ }^{10}$ From 1933 to 1941, about 30,000 Jews escaping Nazi persecution and the Holocaust in Europe found refuge in Shanghai. ${ }^{11}$

In a sense, China was generous with these displaced aliens. The Russians and the Jews entered China with little difficulty and were well settled into the local community. For example, in the late 1930s, when many countries refused Jewish immigration in the wake of the global economic depression, Shanghai was the only major city in the world which desperate Jewish refugees from Europe could enter without a visa. ${ }^{12}$ In Xinjiang, displaced Russians received national treatment and were even able to assume important civil servant jobs in the local Chinese government. ${ }^{13}$

\footnotetext{
8 "Tacheng de waiguo qiaomin [Foreign Sojourners in Tacheng]" (20 July 2011) Tacheng Municipality $<$ http://www.xjtcsh.gov.cn/tcgk/rwsl/201107/t4028a8ab3145442001314701c94f04dd.html> (accessed 28 April 2014); Jianhua Huang and Wenhua Ma "Yang Zhengxin yu eguo nanmin cuanrao Xinjiang shijian [Yang Zhengxin and the Influx of Russian Refugees in Xinjiang]" (1994) 4 Yili shifan xueyuan xuebao [Journal of Yili Teachers' College] 74.

${ }^{9}$ Michael Marrus The Unwanted European Refugees in the Twentieth Century (Oxford University Press, Oxford , $1985)$ at 60.

10 "Foreign Sojourners in Tacheng", above n 8. According to a report by the administrative head of Tacheng, Ruhai $\mathrm{Li}$, on 23 December 1929, poor crop harvest and food shortage this autumn in the Soviet Union had driven many Russians into Tacheng. Li also noticed that there were a significant number of persons who fled to Tacheng for political reasons. Before and after 1930, the agricultural collectivisation movement in the Soviet Union also led to many escapes to China.

${ }^{11}$ The history of Jewish refugees in Shanghai during the 1930s and 1940s has been covered by many books and articles, eg David Kranzler, Japanese, Nazis and Jews, the Jewish Refugee Community of Shanghai 1938-1945, (Yeshiva University Press, New York, 1976); Pamela Rotner Sakamoto Japanese diplomats and Jewish refugees : a World War II dilemma (Praeger, Westport(Conn), 1998); Felix Gruenberger "The Jewish Refugees in Shanghai" (1950) 12 Jewish Social Studies 329; Suzanne Rutland "'Waiting Room Shanghai': Australian Reactions to the Plight of the Jews in Shanghai after the Second World War" (1987) 32 Year book - Leo Baeck Institute 407; Guang Pan "Shanghai: a Haven for Holocaust Victims" United Nations $<$ http://www.un.org/en/holocaustremembrance/docs/paper15.shtml> (accessed 28 April 2014).

12 Pan, above n 11.

13 "Foreign Sojourners in Tacheng", above n 8.
} 
It was not merely out of good will or generosity that China took them in and treated them kindly. After China was forced to open its door to Western powers after the Opium War (1839-1842), it never fully regained the power to control the entry and exit of aliens, especially those from Europe, or to regulate aliens on its soil until the early 1940s. As a consequence of a series of unequal treaties, foreigners enjoyed consular jurisdiction as well as many privileges over Chinese citizens. Displaced foreigners in China, being foreign, thus sometimes had a status superior to Chinese citizens. For example, Felix Gruenberger, who himself was a Jewish refugee in Shanghai, described how in Shanghai refugees were socially ranked lower than other foreigners but higher than Chinese citizens: ${ }^{14}$

Apart from the Japanese occupation forces, there were three social groups in Shanghai. (1) The foreigners. These were the wealthy white Europeans, protected by their consulates, who made up a well-integrated group and who looked down upon anyone who had to do work which was lower than the standard for the white population. (2) The refugees. These consisted first of the Russian refugees and later of the central Europeans. These people were forced by their condition to accept work usually considered unfit for the "whites." (3) The native Chinese. They did the lowest chores and received the lowest wages.

Despite the large numbers of refugees China hosted before 1949, there was no legislation governing the acceptance or management of refugees and very little immigration legislation. The Nationalist government (1911-1949) introduced the first regulations requiring foreigners' passports to be inspected upon entry in $1930 .{ }^{15}$ It was only on 14 November 1944, the eve of the Chinese victory over the Japanese, that legal requirements for aliens to apply for a residence permit to live in and an exit visa to leave China were put into place. ${ }^{16}$ Considering that China was constantly war-torn throughout the 1930s and 1940s, how effectively these regulations were implemented is a question. For instance, during the Anti-Japanese War (1937-1945), Shanghai was occupied by Japanese forces and foreigners did not need a passport or a visa to enter Shanghai.

As such, the Nationalist government did not lay a good foundation for the development of a legal or institutional framework relating to handling refugees or other displaced foreigners in China.

\section{Refugees and Other Displaced Foreigners in China: 1949-1982}

By the time the People's Republic of China was established in October 1949, there were still more than 20,000 refugees in China, including persons of Austrian, Czech, Estonian, Greek, Hungarian, Latvian, Lithuanian, Norwegian, Polish, Romanian, Russian, Spanish, Ukrainian and

\footnotetext{
${ }^{14}$ Gruenberger, above $\mathrm{n} 11$, at 331 .

${ }^{15}$ Guofu Liu Chinese Immigration Law (Ashgate, Farnham (UK), 2011) at 5.

${ }^{16}$ Liu, above n 15, at 5 .
} 
Yugoslav background. ${ }^{17}$ The majority were ethnic Russians who had fled the Soviet Union in the 1920s. ${ }^{18}$ Though the newly-founded People's Republic of China was excluded from the United Nations (UN) at that time, it allowed the International Refugee Organisation (IRO) and later UNHCR to operate in China. Having begun its operation in China in 1947, the IRO operated in China until 1952 when the organisation itself ceased, focusing on finding third country resettlement for refugees in China. ${ }^{19}$ UNHCR took over the IRO's functions in January 1952 and maintained an office of a "special representative" in Shanghai. ${ }^{20}$ When a refugee had an offer of resettlement from a third country, the Chinese government would issue an exit visa to the refugee and the China Travel Service would arrange for the refugee to travel to Shanghai and from there to the China-Hong Kong Border. ${ }^{21}$ Since Beijing did not have diplomatic relations with most of the countries in the world, Hong Kong - then still British Hong Kong - served as a transit point of the refugee's journey to the resettlement destination. UNHCR's office in Shanghai was closed in 1956 and its functions were assumed by the official Chinese People's Relief Association, but the operation of the exit of European refugees continued; by 1969, only around 1,000 European refugees were left in China, of whom 825 had found resettlement in another country and were awaiting exit permits. ${ }^{22}$

The European refugees entered China and integrated into the local community long before the Chinese Communist Party rose to power. Although China gained some experience in cooperating with international agencies during the exit of these refugees which might have been helpful in its repatriation of the Lao and Cambodian refugees in the 1990s, it is unlikely to able to draw upon its experience with the European refugees to deal with refugee influxes.

After 1949, China did not have much experience of receiving refugees or other displaced foreigners until the arrival of Indochinese refugees in 1978. One the one hand, its economic backwardness and Socialist political system may not have looked attractive to outsiders. On the other, China had strictly restricted the entry of aliens in general; there was ubiquitous distrust and hostility towards foreigners, deriving from concerns about spying and China's isolation in international society at that time.

However, China did provide political asylum to a few foreigners from the 1960s to the early 1980s. The most well-known individual who received asylum in China is probably the former King of Cambodia, Norodom Sihanouk. China granted him political asylum when he was deposed and sentenced to death in a coup led by the American-backed General Lon Nol in

\footnotetext{
${ }^{17}$ Between 1952 and 1969, around 20,000 refugees exited China with the help of the United Nations High Commissioner for Refugees (UNHCR); prior to that, the International Refugee Organisation (IRO) resettled about 19,000 to a third country between 1947 and 1952. Glen Peterson "The Uneven Development of the International Refugee Regime in Postwar Asia: Evidence from China, Hong Kong and Indonesia" (2012) 25 Journal of Refugee Studies 326, at 328 and 331.

${ }^{18}$ Peterson, above n 17 , at 329 .

${ }^{19}$ Peterson, above n 17 , at 328 .

${ }^{20}$ Before 1956, China issued exit visas on the condition that the refugee had obtained an entry visa for his or her resettlement country. From spring 1956 onwards, exit visas were issued without precondition. Peterson, above n 17, at 331 .

${ }_{21}^{21}$ Peterson, above $\mathrm{n} 17$, at 330 .

${ }^{22}$ Peterson, above n 17 , at 331 .
} 
$1970 .^{23}$ Norodom Sihanouk lived in China for about 5 years before returning to Cambodia in 1975 .

Kyuichi Tokuda, who was a Japanese Communist Party leader, was granted asylum in China in the early 1950s. Tokuda had participated in the formation of the Japanese Communist Party in the early 1920s and later spent 18 years in prison. ${ }^{24}$ Following his release in 1945, he was elected Secretary General of the Central Committee of the Japan Communist Party and was elected a member of the House of Representatives. ${ }^{25}$ After he was purged from public office in 1950 by the Supreme Commander for the Allied Powers during the Allied Occupation of Japan, he went into exile in China and died in Beijing in $1953 .^{26}$

Asylum was also provided to an Indonesian ambassador to China, Djawoto, in April 1966 in the midst of intensifying diplomatic and political tension between Beijing and Jakarta. ${ }^{27}$ Djawoto later assumed the position of Secretary-General of the Afro-Asian Journalists' Association in Beijing and lived there for more than a decade.

From the late 1960s to the early 1980s, China provided refuge to a team of Malayan Communist Party members in exile, who set up and run the Suara Revolusi Malaya (the Voice of the Malayan Revolution) radio station in China's southern Hunan Province. ${ }^{28}$ From 1961 to 1980, Chen Pin (also known as Pin Cheng), a Malayan Communist Party leader, also lived in exile in China after the Malayan Emergency (1948-1960). ${ }^{29}$

Several Vietnamese "defectors" were granted asylum in the late 1970s and early 1980s when the ideological rift between China and Vietnam was acute. Though the time they came to China coincided with that of the massive influx of Indochinese refugees, they came and received asylum in a different manner. In July 1979, the then Deputy Chairman of the Vietnamese National Assembly and former Vietnamese ambassador to China, Hoang Van Hoan, who had been known for his strong pro-Chinese sentiments, made his way to China after his flight from Hanoi to East Berlin stopped to refuel in Karachi, Pakistan. ${ }^{30}$ It was only a few months after the Sino-Vietnam war; Hoang was well received by China and spent the rest of his life in China. On 2 December 1978 and 16 December 1981, the official newspaper of Communist Party of China,

\footnotetext{
${ }^{23}$ Michael P Colaresi Scare Tactics: The Politics of International Rivalry (Syracuse University Press, Syracuse, 2005), at 197; "qingyi wuxian xihanuke 'liuwang' zhongguo wunian jishi [Infinite Friendship: True Stories of Sihanouk's 5 Years of 'Exile' in China]" China Net (21 July 2010) <http://culture.china.com/zh_cn/history/files/11022841/20100721/16035891_1.html> (accessed 28 April 2014).

24 "waiguoren ruhe dedao zhongguo 'bihu' [How Can Foreigners Receive Asylum in China]" (18 December 2013) Sohu News <http://news.sohu.com/s2013/dianji-1291/> (accessed 11 April 2014).

${ }_{25}$ “Tokuda, Kyuichi” National Diet Library, Japan <http://www.ndl.go.jp/portrait/e/datas/407.html?cat=119> (accessed 11 April 2014).

26 "How Can Foreigners Receive Asylum in China", above n 24; "Tokuda, Kyuichi”, above n 25.

${ }^{27}$ David Mozingo Chinese Policy toward Indonesia, 1949-1967 (Cornell University Press, Ithaca, 1976) at 250.

28 "How Can Foreigners Receive Asylum in China", above n 24; "Malayan People's Army. 10th Regiment Archives" International Institute of Social History <http://www.iisg.nl/archives/en/files/m/ARCH02799.php> (accessed 11 April 2014).

${ }^{29}$ Yinghong Cheng "magong zongshuji Chen Ping de chuanqi rensheng [The Legendary Life of the Former Secretary General of the Malayan Communist Party, Chen Ping]" Phoenix Weekly (online ed, Hong Kong, 16 October 2013).

${ }^{30}$ Sung An Tai "Vietnam: the Defection of Hoang Van Hoan" (1980) 7 Asian Affairs 288 at 288.
} 
the People's Daily, reported that asylum was provided to a Vietnamese cadre and a group of ten Vietnamese including a pilot officer. ${ }^{31}$ The former, according to his interview with the People's Daily, crossed into China because he felt under great pressure from the Vietnamese government after expressing his objection to anti-China policies and anti-ethnic Chinese measures in Vietnam. The latter escaped to China in a military helicopter due to discontent with Vietnam's "cruel ruling and political persecution".

The first refugee crisis China faced was the Indochinese refugee influx, starting from 1978. In April 1978, large numbers of people began to flood into China from Vietnam. The majority of them, in hundreds of thousands, entered China from Vietnam by land and by boat through Guangxi Zhuang Autonomous Region, which is a main gateway between China and Vietnam (see Map 2); tens of thousands crossed into Yunnan Province from Vietnam and Laos. ${ }^{32}$ By the early 1980 s, more than 280,000 people had arrived. ${ }^{33}$ About 98 per cent of them were ethnic Chinese who had been living in Vietnam, Laos and Cambodia. ${ }^{34}$

Upon their arrival, they received assistance from the Chinese government. Shelter, food, clothes, medicine and a daily allowance were provided to them by the local authority. The Office of Reception and Resettlement of Indochinese Refugees was established at the state and provincial level to facilitate and oversee the reception and resettlement process. In the small border town of Dongxing in Guangxi for example, the local authority assigned 240 government workers and hired another 240 external support workers to deal with the reception of the refugees. When the first refugees arrived, public buildings such as government offices, school dormitories, warehouses, canteens and meeting rooms as well as private houses were mobilised to accommodate refugees. As the number of refugees continued to increase, 13,000 square metres of makeshift houses were built in and around Dongxing for the refugees. The government also transformed a hotel into an elderly care centre to receive elderly, unaccompanied or sick refugees. Beds, mosquito nets, blankets, mattresses and other necessities were distributed to refugees. Doctors were sent to provide medical care to the refugees and vaccinations were provided.

\footnotetext{
${ }^{31} \mathrm{Li}$ Zhang "Ta zenyang maoxian laidao zhongguo - fangwen yuenan ganbu ruantingyin [How He Risked to Come to China-Interview with VietnameseOfficer Ruan Tingyin]" Remin Ribao (China, 2 December 1978) at 4; "wo youguan bumen genju zhongguo falü guiding yunxu qiaoqinglu deng shiren zai woguo juliu [Chinese Governing Department Allowed Ten Persons including Qiao Qinglu to Reside in China according to Chinese Legal Provisions]" Remin Ribao (China, 16 October 1981) at 1. Both are available at renmin ribao archive 1946-2003 $<$ www.rmrbw.net>.

${ }^{32}$ Shuying Liang guoji nanmin fa [International Refugee Law] (Intellectual Property Publishing House, Beijing, 2009), at 276.

${ }^{33}$ Liang, above n 32, at 272.

34 Jing Song "Vietnamese refugees well settled in China, await citizenship" (10 May 2007) UNHCR $<$ http://www.unhcr.org/464302994.html > (accessed 28 April 2014).
} 
Map 2 Administrative Map of China

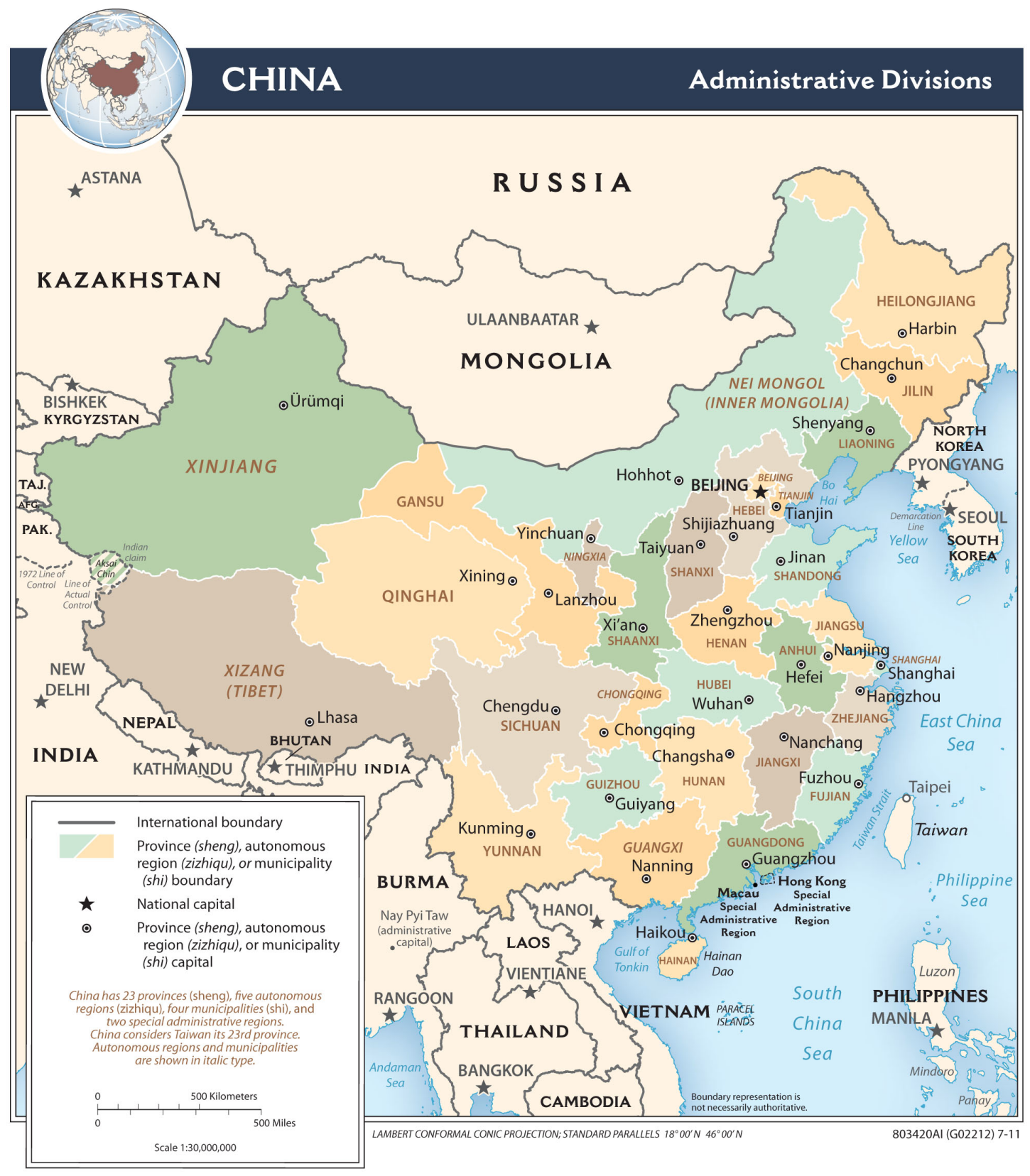

Source: the United States Central Intelligence Agency, available at $<$ https://www.cia.gov/library/publications/ciamaps-publications/map-downloads/china_admin.jpg/image.jpg > (accessed 16 April 2014). 
Later, the refugees were given jobs on Overseas Chinese Farms (OCF) in Guangxi Zhuang Autonomous region (equivalent of province), Guangdong Province, Hainan Province (part of Guangdong Province before mid-1980s), Yunnan Province, and Jiangxi Province in south and southwest China and refugees were transferred from the border area to resettlement places. Guangxi and Guangdong, where many of the refugees or their ancestors were originally from and where a climate similarity to Southeast Asian can be found, together hosted around 200,000 refugees. ${ }^{35}$ A significant proportion of the refugees, with few occupational qualifications, were resettled on existing and newly established OCFs; refugees with a fishing background were provided with suitable facilities to resume their trade in fishing villages; others were absorbed by mines, factories and small township enterprises. ${ }^{36}$

The refugee status of the Indochinese was recognised by the Chinese government at a working meeting on Indochinese refugees (the 1979 Meeting) on 4 August 1979, which was presided by then Chairman of China Li Xiannian and Vice Minister of the State Council Chen Muhua and attended by high ranking officials from provincial governments and Central Government ministries and departments involved in receiving and settling the Indochinese refugees. The meeting required that all Vietnamese, Laos and Cambodians who were expelled by Vietnamese authorities and escaped to China should be referred to as refugees without exception. ${ }^{37}$

In addition to those who came directly from Vietnam and Laos, China also offered resettlement to 2,552 Indochinese refugees from refugee camps in Thailand in $1980 .^{38}$ The majority of them were Lao and Cambodian refugees. Resettlement was also provided to 245 and 17 Indochinese refugees in 1981 and 1982 respectively. ${ }^{39}$

In 1991, China signed a protocol with Laos on the repatriation of Lao refugees. With the coordination of UNHCR, 3,550 refugees voluntarily returned to Laos between 1991 and $1997 .{ }^{40}$ During the same period, more than 30 Cambodian refugees were also repatriated through the coordination of UNHCR and cooperation between the Chinese and Cambodian government. There are currently about 5 families of Cambodian refugees and over 800 Lao refugees remaining in China. ${ }^{41}$ Nowadays, the number of Indochinese refugees living in China has grown to about 300,000 . They are well integrated into the local communities and receive continuous support from the Chinese government and UNHCR. ${ }^{42}$ Their local integration is considered by the former UN High Commissioner for Refugees António Guterres as "one of the most

\footnotetext{
${ }^{35}$ Liang, above n 32, at 280.

${ }^{36}$ Tom Lam "The exodus of hoa refugees from Vietnam and their settlement in Guangxi-China's refugee settlement strategies" (2000) 13 Journal of Refugee Studies 374.

${ }^{37}$ Liang, above n 32, at 274 . It is worth mentioning that China was not a party to the Refugee Convention and Protocol in 1979.

${ }^{38}$ David Feith Stalemate: Refugees in Asia (Asian Bureau Australia, Parkville, 1988), appendix. Cambodia has no land border with China.

${ }^{39}$ Feith, above $\mathrm{n} 38$, appendix.

${ }^{40}$ Liang, above $\mathrm{n} 32$, at 306.

41 UNHCR "UNHCR Regional Representation in China" UNHCR $<$ http://www.unhcr.org.hk/unhcr/en/about_us/China_Office.html > (accessed 28 April 2014).

${ }^{42}$ Lam, above $\mathrm{n} 36$, at 378 .
} 
successful integration programs (of refugees) in the world". ${ }^{43}$ Though they have not been naturalised, ${ }^{44}$ most of them have been registered in the household registration (hukou) system and obtained a Chinese identity card, ${ }^{45}$ which enables them to stay legally in China and enjoy a socio-economic status on a par with Chinese citizens, ${ }^{46}$ for example, they are allowed to work and entitled to social welfare and public education. Some of them have been issued a Chinese passport. $^{47}$

The influx of the Indochinese refugees led to the establishment of a UHNCR mission office in Beijing in 1980 and China's accession to the Convention and Protocol in 1982. Why and how China recognised the Indochinese as refugees and the impact of the Indochinese refugee influx will be further considered in chapter IV.

\section{Refugees and Other Displaced Foreigners in China: 1983-2013}

\section{A UNHCR Refugees}

In the post-Indochinese influx era, the Office of UNHCR in Beijing has taken the lead to conduct RSD in China. China does not substantially involve itself in the RSD process administered by UNHCR. ${ }^{48}$ China acknowledges the refugee status of those who are identified as refugees through the RSD process conducted by UHNCR Beijing Office (UNHCR refugees) and allows them to stay temporarily in China until a durable solution, usually resettlement in a third country, is found by UNHCR for them. ${ }^{49}$ The number of refugees and asylum seekers received by China remained low until the mid-1990s, but has gradually increased since. ${ }^{50}$

Published information about non-Indochinese refugees and asylum seekers prior to 1996 is extremely scarce. Muntarbhorn noted that non-Indochinese asylum seekers were numbered at fewer than 50 in 1990 and that "little is heard of their fate, but generally they have been treated on a case-by-case basis with the knowledge of UNHCR". ${ }^{51}$ An UNHCR "Update on Regional Developments in Asia and Oceania" dated 19 August 1996 indicated that as of 1 January 1996, there were 288,300 refugees in China. Among them only 45 were non-Indochinese refugees, including 28 Somalis, eight Burundians, four Rwandans, three Iranians, one Sri Lankan, and one

\footnotetext{
${ }^{43}$ Song, above n 34.

${ }^{44}$ Song, above $\mathrm{n} 34$.

${ }^{45}$ United States Committee for Refugees and Immigrants (USCRI) "World Refugee Survey" (2009) USCRI $<$ http://www.refugees.org/resources/refugee-warehousing/archived-world-refugee-surveys/2009-wrs-countryupdates/china.html > (accessed 28 April 2014); Liang, above n 2, at 265.

${ }^{46}$ UNHCR, above $\mathrm{n} 41$.

${ }^{47}$ Song, above $\mathrm{n} 34$.

48 Yuanjun Wang "guanyu jianli woguo nanmin baohu falv zhidu de jidian sikao [Several Thoughts on Establishment of Refugee Protection Mechanism in China]" (2005) 12 Public Security Research 46 at 47; UNHCR Regional Representation for China and Mongolia "Fact Sheet" (March 2014) UNHCR $<$ http://www.unhcr.org/5000187d9.html> (accessed 28 April 2014). The RSD mechanism in China will be further considered in chapter $\mathrm{V}$.

${ }^{49}$ UHNCR, above n 41 . Note that art 46 of the Exit-Entry Law, which entered into force on 1 July 2013, allows refugees to reside in China, but whether this article is going to be implemented effectively is to be seen. See Chapter III.

${ }^{50}$ Liang, at 272.

${ }^{51}$ Vitit Muntarbhorn The Status of Refugees in Asia (Clarendon Press, Oxford, 1992) at 66.
} 
Sudanese. The rest were Indo-Chinese refugees. ${ }^{52}$ According to the statistics on the UNHCR website, the number of UNHCR refugees in China was well under 100 in the early 2000s, but has risen significantly in the past 10 years (see Chart 2). The number of asylum seekers and other persons of concern to UNHCR fluctuated in the past decade but is generally much higher than in the early 2000s. As at September 2013, 300,895 Indochinese refugees, 166 UNHCR refugees, and 332 asylum seekers were living in China according to UNHCR. The actual number of refugees and other displaced foreigners in China is estimated to be higher, as UNHCR does not always have access to refugees and asylum seekers in China. ${ }^{53}$

Chart 2 Numbers of UNHCR Refugees and Asylum Seekers in China 2000-2014

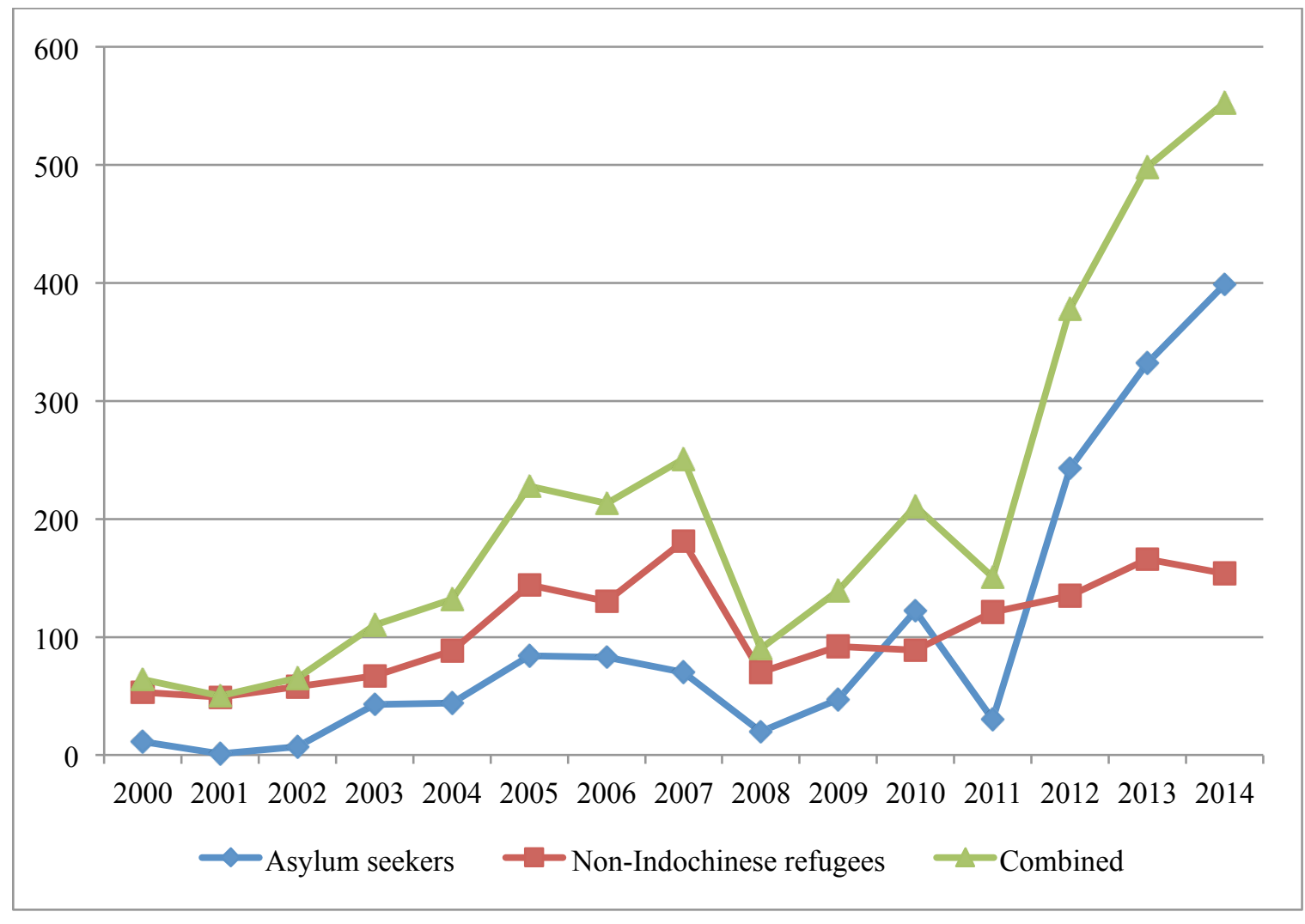

Source: $\quad$ Online $\quad$ Statistical Population $\quad$ Database $<$ http://popstats.unhcr.org/\#_ga=1.62031726.356743116.1347279548> (accessed 27 January 2014); UNHCR Regional Representation for China and Mongolia "Fact Sheet" (March 2014) $<$ http://www.unhcr.org/5000187d9.html> (accessed 20 August 2014).

Note: the 2014 numbers are as in March 2014.

\footnotetext{
${ }^{52}$ UNHCR “Update on Regional Developments in Asia and Oceania”, EC/46/SC/CRP.44 (1986) at [74].

${ }^{53}$ UNHCR's requests to access North Koreans, the ethnic Kokangs and the ethnic Kachins in China were generally denied by the Chinese government. UNHCR "UNHCR Seeks Access to North Koreans Detained in China" (21 January 2003) UNHCR <http://www.unhcr.org/3e2d81b94.html> (accessed 28 April 2014); UNHCR "China: UNHCR Calls for Access to Myanmar Refugees” (4 September 2009) UNHCR $<$ http://www.unhcr.org/4aa108159.html> (accessed 28 April 2014); UNHCR "UNHCR Reaches Kachins Sent back from China" (7 September 2012) UNHCR <http://www.unhcr.org/5049cdba9.html> (accessed 28 April 2014).
} 
Unlike Indochinese refugees who settled in local communities, UNHCR refugees are largely scattered in urban areas of China's major cities (see Chart 3 and Map 2). To date, published information about the situation of UNHCR refugees in China remains relatively sparse.

Chart 3 Demographic Composition of Populations of Concern to UNHCR in China in 2012

\begin{tabular}{|c|c|c|c|c|}
\hline $\begin{array}{c}\text { Series } \\
\text { number }\end{array}$ & Location of residence & Female total & Male total & Overall total \\
\hline 1 & Beijing City & 9 & 29 & 38 \\
\hline 2 & Fujian Province & 13,211 & 14,198 & 27,409 \\
\hline 3 & Gan Su Province & $*$ & $*$ & $*$ \\
\hline 4 & Guangdong Province & 39,928 & 43,708 & 83,636 \\
\hline 5 & Guangxi Autonomous Region & 53,303 & 58,965 & 112,268 \\
\hline 6 & Hainan Province & 14,867 & 16,608 & 31,475 \\
\hline 7 & Ji Lin Province & $*$ & $*$ & $*$ \\
\hline 8 & Jiangxi Province & 824 & 891 & 1,715 \\
\hline 9 & Langfang City & 11 & 22 & 33 \\
\hline 10 & Nanjing City & 5 & 8 & 13 \\
\hline 11 & Shaanxi Province & $*$ & $*$ & $*$ \\
\hline 12 & Shan Dong Province & $*$ & $*$ & $*$ \\
\hline 13 & Shanghai City & & $*$ & $*$ \\
\hline 14 & Tianjin City & & $*$ & $*$ \\
\hline 15 & Wuhan City & 79 & 58 & 137 \\
\hline 16 & Yiwu City & $*$ & $*$ & $*$ \\
\hline 17 & Yunnan Province & 21,821 & 22,669 & 44,490 \\
\hline
\end{tabular}

Source: UNHCR (accessed 27 January 2014).

Note: (1) statistics for Fujian, Guangdong, Guangxi, Hainan, Jiangxi and Yunnan include Indochinese refugees; (2) statistics displayed as asterisks (*) represent figures which are kept confidential by UNHCR to protect the anonymity of persons of concern. Such figures are not included in any totals.

An article in 2004 in a Chinese magazine gave a glimpse into the stories and life of UNHCR refugees in China, and illustrates the treatment they receive from the Chinese government. ${ }^{54}$ It mentioned a refugee from Sri Lanka under the pseudonym of Hamai who was a leader of an

\footnotetext{
${ }^{54}$ Xiao Shao "shenghuo zai zhongguo de waiguo nanmin [Foreign Refugees Living in China]" Baixing [Ordinary People] (China, March 2004) at 50.
} 
anti-terrorism organisation in Sri Lanka. Because Hamai organised influential anti-terrorism photo exhibitions around Sri Lanka, he was repeatedly threatened by terrorists and found himself in seriously dangerous situations several times. Hamai left Sri Lanka and was recognised as a refugee by UNHCR in China. He was living in a big city in China at the time of the article. The article also mentioned a Burundian who came to China as an exchange student in the late 1980s. When he was about to returned to his country after seven years study in China, large-scale ethnic conflicts erupted in Burundi. He was recognised as a "person of concern" by UNHCR and allowed to stay in China by the Chinese government. He rented an apartment in a Beijing suburb and lived with his wife and children. However, he was not allowed to work, though he had a master's degree in industrial design, and had to live on a monthly allowance provided by UNHCR. With the help of UNHCR, he moved to Canada a few years later.

A more recent article in 2013 shows that conditions of UNHCR refugees in China had largely remained the same in the past decade, but positive changes were emerge. This article in Global Time, which is a state-owned newspaper in China, introduces the story of Taonga, a Zimbabwean-artist-turn-refugee. ${ }^{55}$ Fleeing discrimination and threats for being homosexual in his native Zimbabwe, Taonga came to China to join his Chinese boyfriend in 2012 on a tourist visa and later registered as a refugee with UNHCR. Taonga was not allowed to work, open a bank account, or travel without approval. When he wanted to leave Beijing to attend a friend's wedding in Sichuan Province, he was advised that it would be better to stay in Beijing because local authorities in Sichuan might have problems with his refugee identity. The article also mentioned that a teenage refugee from Pakistan, who fled with his family for religious reasons, had received home tuition from volunteers arranged by UNHCR and was enrolled in a Chinese public school as a result of the Chinese government's policy decision in November 2012 to allow refugee children to attend public schools in China.

As illustrated in the above articles, UNHCR refugees, as well as "persons of concern" to UNHCR, are allowed to stay in China temporarily until UNHCR finds resettlement for them in a third country or repatriation to their home country is possible. The Chinese government does not issue travel documents to UNHCR refugees or "persons of concern" to UNHCR, nor does it grant them the right to employment. ${ }^{56}$ They hold identification documents issued by UNHCR and rely on UNHCR for assistance in terms of food, accommodation, health care, and children education. ${ }^{57}$ In November 2012 the Chinese government began to allow children of UNHCR refugees to access public education in primary schools under the same condition as local children. ${ }^{58}$ This is a recent positive development in the treatment of UNHCR refugees in China.

\section{B Refugees and Other Displaced Foreigners Dealt with by the Chinese Government}

Despite the fact that China is not substantially involved in the RSD process administered by UNHCR, it dealt with at least three mass influxes of displaced aliens from neighbouring

\footnotetext{
${ }^{55}$ Meilian Lin "Home away from home" Global Times (online ed, China, 22 December 2013).

${ }^{56}$ UNHCR, above n 41; Liang, above n 32, at 260.

${ }^{57}$ UNHCR, above $\mathrm{n} 41$.

${ }^{58}$ UNHCR Regional Presentation for China and Mongolia, above n 48.
} 
countries in the past 20 years, namely the arrival of North Koreans since the mid-1990s, the socalled "Kokang Incident" in 2009 and the Kachin influx from 2011 to 2012, and it has generally denied UHNCR's access to these displaced foreigners.

In the mid-1990s when a food shortage hit North Korea heavily, large numbers of North Koreans began to risk crossing the shallow Tumen River into northeast China illegally in search of food. The inflow continues nowadays. ${ }^{59}$ As the Chinese government does not release information regarding the total number of North Korean escapees and UNHCR are not allowed to operate in the north-eastern provinces of China, where the majority of the North Korean escapees live, there is little reliable statistical information regarding the number of North Korean refugees in China. The estimated number of undocumented North Korean escapees in China varies from 5,000 to $100,000 .^{60}$ The Chinese government has insisted that North Korean escapees in China are illegal economic migrants, although scholars and human rights groups have argued that many of the North Korean escapees qualify for refugee status. ${ }^{61}$ Generally, North Korean escapees in China have no access to RSD procedures and face the risk of deportation if caught by Chinese authorities.

Though China persists in its position that North Koreans in China are not refugees, China's treatment of North Koreans has not always been consistent. A few local authorities allowed certain types of North Koreans, mainly females who are married to Chinese men and have children, and those who have lived in China for a long period without causing problems, to stay and even issued temporary resident permits or identification cards to them, ${ }^{62}$ though probably without the consent of the central government.

\footnotetext{
${ }^{59}$ For discussion on North Koreans' motivations to leave North Korea, see eg Stephan Haggard and Marcus Noland Witness to Transformation: Refugee Insights into North Korea (Peterson Institute for International Economics, Washington DC, 2011), at 29; Human Rights Watch (HRW) "The Invisible Exodus: North Koreans in the People's Republic of China" (November 2002) HRW <http://www.hrw.org/reports/2002/northkorea/> (accessed 28 April 2014) at 9; Rhoda Margesson, Emma Chanlett-Avery and Andorra Bruno "North Korean Refugees in China and Human Rights Issues: International Response and U.S. Policy Options" (26 September 2007), available at United States Congressional Research Service Report for Congress <https://www.fas.org/sgp/crs/row/RL34189.pdf> (accessed 28 April 2014) at 6.

${ }^{60}$ Haggard and Noland, above n 59, at 2. See also eg United State Congressional-Executive Commission on China "2013 Annual Report" (10 October 2013), at 118, available at United State Congressional-Executive Commission on China <http://www.cecc.gov/publications/annual-reports/2013-annual-report> (accessed 28 April 2014). The report says that international scholars and media estimate the number is currently between 11,000 and 50,000.

${ }^{61}$ For legal analysis on the status of North Korean escapees, see eg Roberta Cohen "Legal Grounds for Protection of North Korean Refugees" (12 September 2010) Brookings $<$ http://www.brookings.edu/research/opinions/2010/09/north-korea-human-rights-cohen> (accessed 28 April 2014); Elim Chan and Andreas Schloenhardt "North Korean Refugees and International Refugee Law" (2007) 19 International Journal of Refugee Law 215; Benjamin Neaderland "Quandary on the Yalu: International Law, Politics, and China's North Korean Refugee Crisis" (2004) 40 Stanford Journal of International Law 143.

${ }^{62}$ Liu, above $\mathrm{n} \mathrm{15}$, at 91; "2012 nian zhongshan daxue moni lianheguo dahui nanmin anzhi yu nanmin quanli baozhang beijing wenjian [2012 Sun Yat-Sun University Moot UN Meeting on Refugee Settlement and Rights Protection Background Document]" (19 April 2012) School of Asian Pacific Study of Sun Yat-Sen University $<$ http://saps.sysu.edu.cn/xsyd/zsdxmnlhg/96477.htm> (accessed 9 March 2013).
} 
Map 3 Administrative Map of Myanmar

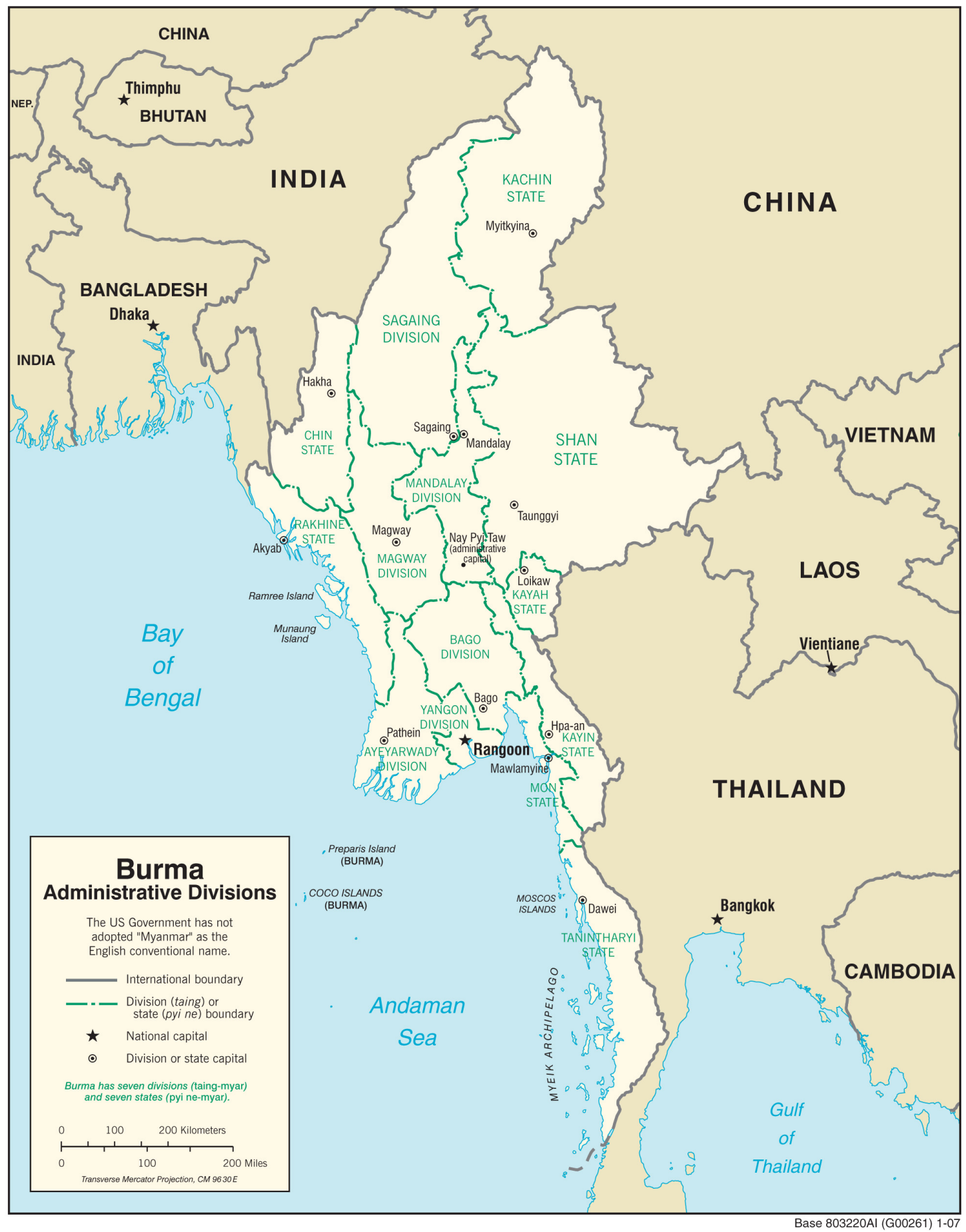

Source: the United States Central Intelligence Agency, available at $<$ https://www.cia.gov/library/publications/ciamaps-publications/map-downloads/burma_admin.jpg/image.jpg> (accessed 16 April 2014).

Note: Myanmar moved the capital of the country to Naypyidaw in 2005. 
Another influx is the arrival of ethnic Kokangs from Myanmar in 2009, which is generally known as the Kokang Incident in Chinese media (see Map 3). On 8 August 2009, tensions between Myanmar's central government troops and the local army of the Kokang Special Region (the Kokang Region) in Shan State suddenly increased. ${ }^{63}$ Panicked Kokangs began to flee to the bordering Nansan town in Yunnan Province, China. In the following weeks, as gunfire broke out and intensified in Kokang Region, about 37,000 civilians flooded into Yunnan Province. ${ }^{64}$ The Chinese government quickly opened seven temporary camps for the displaced Kokangs, setting up more than 1,000 tents and providing RMB 10 million (about USD 1.6 million) worth of food, blankets, drinking water, medicine and daily allowance. ${ }^{65}$ The Minister of Public Security was sent to Yunnan Province to lead the "stability-keeping" (weiwen) work. ${ }^{66}$ The Chinese government never referred to the displaced Kokangs as refugees (nanmin), only as border residents (bianmin), ${ }^{67}$ although many Chinese mainstream media referred to them as refugees. In early September 2009, the displaced Kokangs gradually returned to Myanmar voluntarily as the fighting in Kokang eased, and the camps were removed. ${ }^{68}$

On 9 June 2011, less than two years after the Kokang Incident, armed conflicts between Myanmar government troops and the Kachin Independence Army (KIA) forced about 40,000 ethnic Kachins to flee towards the Myanmar-Chinese border. ${ }^{69}$ Though the situation of the Kachins appears to be similar to that of the Kokangs in August 2009, China seems to have taken a different approach to the Kachins. It was reported in mid-June 2011 that about 1,000 Kachins attempted to enter China, but only about 200 people, mostly elderly people and women with children, were allowed in by the Chinese border security forces. ${ }^{70}$ But a spokesperson for

\footnotetext{
${ }^{63}$ Euro-Burma Office (EBO) "The Kokang Clashes - What Next?" (September 2009) EBO <http://euroburma.eu/doc/EBO_Analysis_No_1_(Kokang).pdf> (accessed 28 April 2014) at 4.

${ }^{64}$ State Council Information Office of the People's Republic of China (SCIO) "Yunnan Sheng zhengfu jiu dangqian zhongmian bianjing jushi juxing xinwen fabuhui [Yunnan Government Holds Press Conference on Situation on $\begin{array}{lllll}\text { China-Myanmar } & \text { Border]" } & \text { (31 } & \text { August } & \text { 2009) }\end{array}$ $<$ http://www.scio.gov.cn/xwfbh/gssxwfbh/xwfbh/yunnan/200908/t398584.htm> (accessed 14 September 2011). According to the SCIO, the number is inclusive of Chinese citizens returning home from Kokang due to the armed conflict.

${ }^{65}$ SCIO, above n 64; "Kokang Capital Falls: 'Not Shoot First' Policy under Fire" (26 August 2009) Shan Herald Agency for News <http://www.shanland.org/index.php?option=com_content\&view=article\&id=2695:kokangcapital-falls-not-shoot-first-policy-under-fire\&catid=86:war\&Itemid=284> (accessed 14 September 2011).

${ }^{66}$ SCIO, above n 64.

${ }^{67}$ People's Republich of China Ministry of Foreign Affairs (MFA) press conference, Beijing, 1 September 2009. Transcripts of all MFA press conferences mentioned in this thesis are available at MFA <www.fmprc.gov.cn>.

${ }^{68}$ Jun Liu "30,000 ming guogan nanmin tashang miandian guitu [30,000 Kokang Refugees on Their Way Home]" (16 September 2009) China Weekly <http://www.chinaweekly.cn/bencandy.php?fid=60\&id=4491> (accessed 14 September 2011); Shan Nan "Beijing chaichu yingdi qianfan guogan nanmin [Beijing Removed Camps and Repatriated Kokang Refugees]" (1 September 2009) Asia News <http://www.asianews.it/newszh/\%E5\%8C\%97\%E4\%BA\%AC\%E6\%8B\%86\%Е9\%99\%A4\%E8\%90\%A5\%Е5\%9C\%B0\%Е9\%81\%A3\%Е8\%BF $\% 94 \% \mathrm{E} 6 \% 9 \mathrm{E} \% 9 \mathrm{C} \% \mathrm{E} 6 \% 95 \% \mathrm{A2} \% \mathrm{E} 9 \% 9 \mathrm{~A} \% \mathrm{BE} \% \mathrm{E} 6 \% \mathrm{~B} 0 \% 91-16205 . \mathrm{html}>$ (accessed 13 September 2011).

69 "Kachin IDPs Reach over 40,000 due to Civil War in Northern Burma" (2 September 2011) Kachin News $<$ http://www.kachinnews.com/news/2040-kachin-idps-reach-over-40000-due-to-civil-war-in-northern-burma.html> (accessed 28 April 2014).

70 Yan Naing Saw "Kachin Conflict Sparks Refugee Situation" (15 June 2011) The Irrawaddy $<$ http://www2.irrawaddy.org/article.php?art_id=21495> (accessed 28 April 2014); "Miandian keqin wuzhuan zan bu pohuai zhongmian youqi guandao deng zhongguo huiying [Burma's Kachin Army Has not Ruined ChinaMyanmar Oil and Gas Pipes, Awaiting China's Response]" (6 June 2011) China News $<$ http://www.chinanews.com/gj/2011/06-16/3115812.shtml> (accessed 28 April 2014).
} 
China's Ministry of Foreign Affairs (MFA) denied that the border was closed, saying that border residents from Myanmar had "come to China to live with their friends and relatives temporarily" and that China provided "necessary assistance in conformity with common practices on the basis of humanitarianism". ${ }^{71}$ In late June and early July 2011, the Chinese authorities told displaced Kachins who were allowed into China earlier that fighting had terminated at their village and persuaded them to return to Myanmar. ${ }^{72}$

Later, the Chinese government's attitude towards the Kachins became more tolerant. Kachins seeking to enter China were generally allowed to enter and stay in Yunnan Province. By June 2012, it was estimated that 7,000 to 10,000 displaced Kachins were staying in China's Yunnan Province. ${ }^{73}$ The majority of them were living in groups at temporary camps, which were selfbuilt by the displaced Kachins or converted from warehouses, while others stayed with relatives, friends or in rented rooms. ${ }^{74}$ China provided little assistance to them, but allowed a few relief groups to access and to assist the Kachins. ${ }^{75}$ In August 2012, however, China began to send back the displaced Kachins who were staying in the camps. In September 2012, UNHCR estimated that about 5,000 Kachins had been sent back to Myanmar. ${ }^{76}$ Those who were staying in private houses were allowed to remain. ${ }^{77}$

\section{Refugees and Other Displaced Foreigners and Chinese Civil Society}

Chinese society in general knows very little about refugees. Most Chinese are not familiar with the notion of a refugee, and would be surprised to know that there are refugees in China. Their ignorance of refugees probably could be attributed primarily to the lack of available information of the subject in Chinese language. Publications and media coverage of refugees in Chinese media are rare; studies on refugees and refugee law are emerging only recently. ${ }^{78}$

In the small volume of Chinese literature on refugees, a significant proportion is related to the Indochinese refugees and was produced in the late 1970s and early 1980s when they first arrived, usually focusing on the situation upon their arrival and denouncing the Vietnamese government. In-depth analysis on their legal status and follow-up research on the social impact of the influx or the refugees' local integration are lacking. As years passed by, they somehow received

\footnotetext{
${ }^{71}$ MFA press conference, Beijing, 16 June 2011.

72 Kaung Ba "Kachin State Refugees Face Uncertain Future" (1 July 2011) The Irrawaddy $<$ http://www2.irrawaddy.org/article.php?art_id=21612> (accessed 28 April 2014); "Aid Groups Say China is Expelling Kachin Refugees" (23 June 2011) VOA <http://blogs.voanews.com/breaking-news/2011/06/23/aidgroups-say-china-is-expelling-kachin-refugees/> (accessed 28 April 2014). The fighting, nonetheless, has been going on and off since the Myanmar government and the KIA have not succeeded in reaching a ceasefire agreement as of March 2014.

${ }^{73}$ HRW "Isolated in Yunnan: Kachin Refugees from Burma in China's Yunnan Province" (June 2012) Human Rights Watch <http:/www.hrw.org/sites/default/files/reports/china0612_forinsertForUpload.pdf $>$ (accessed 28 April 2014) at 36.

${ }_{74}$ Interview conducted by the author (April 2013).

${ }^{75}$ Interview conducted by the author (April 2013). See also HRW, above n 73, at 11.

${ }^{76}$ UNHCR "UNHCR reaches Kachins sent back from China", above n 53.

${ }^{77}$ Interview conducted by the author (April 2013).

${ }^{78}$ Liang Shuying's book International Refugee Law, which was published in 2009, was referred to "the first of its kind in China" by Veerapong Vongvarotai, then UNHCR Regional Representative for China \& Mongolia, in his foreword for the book.
} 
decreasing attention from Chinese society. There have been only occasional reports on the Indochinese refugees in China in the past three decades in main stream Chinese media. By 2009, they had become "a silent community" ${ }^{79}$ In particular, when the Indochinese refugees came, they were largely perceived as overseas Chinese returning to the motherland. ${ }^{80}$ The fact that they were settled on overseas Chinese farms has further caused confusion about their status and blurred their image as refugees.

In recent years, more and more information about refugees in China is becoming available. The Kokang Incident in 2009 was a turning point. The incident was widely covered by mainstream Chinese media and stirred up some discussion on China's refugee policy in newspapers and among netizens. The Kachin influx in 2011 and 2012 further attracted attention of a wider audience to refugee issues. At the meantime, stories of North Korean escapees, which used to be almost a taboo, began to appear in China's mainstream media; there is also a small number of academic articles and theses on North Korean escapees. ${ }^{81}$

In February 2012 the website of China's national television posted an article on accepting refugees and asked readers two questions: (1) "what do you think of refugees?", and (2) "what do you think of illegal border crossers (feifa rujingzhe)?"82 Each question came with three options which readers were invited to choose from. The results are as shown in Charts 4 and 5:

\footnotetext{
${ }^{79}$ Buzhi Ding, Zhen Xu and Jialin Liang "yige yi cunzai 30 nian de chenmo qunti: 30 wan nanmin zai zhongguo [A Silent Community that Have Existed for 30 Years: 300 Thousand Refugees in China]" (2009) Nanfang zhoumo (Southern Weekly) (online ed, Guangzhou, 15 Oct 2009). A possible explanation for their silence may be two fold. On the one hand, possibly due to the warming Sino-Vietnamese relations and China's intention of not embarrassing Vietnam, the Chinese government has been low key about its effort in settling and continuously supporting the Indochinese refugees in China. On the other hand, the Indochinese refugees, who still do not have Chinese nationality, are subject to the Chinese government's permission to live in China; this perhaps makes them cautious about catching social attention deemed undesirable by Chinese authorities.

${ }^{80}$ See Chapter IV and Chapter VI.

${ }^{81} \mathrm{Eg}$ Jianan Ge "chaoxian tuobeizhe jiangshu chutao jingji: dongtian dujiang dao zhongguo [North Korean 'Escapees' Tell Their Fleeing Stories: Crossing Rivers to China in Winter]" (24 January 2014) NetEase $<$ http://news.163.com/14/0124/18/9JCGBCKK0001121M_all.html> (accessed 12 February 2014); "chaoxian tuobeizhe laihua jing dongnanya fuhan xiangxi luxian baoguang [Revealing Detailed Route Used by North Korean Escapees to Go to South Korea from China via Southeast Asia]" (26 December 2013) Sina $<$ http://news.sina.com.cn/c/2013-12-26/015629082245.shtml> (accessed 28 April 2014); Ruobing Chen (ed) "yige 'tuobei' jiating de 10 nian [Ten Years of a 'North Korean Escapee' Family]" (5 January 2012) Tengxun $<$ http://news.qq.com/zt2011/shijie/nkrefugee.htm> (accessed 28 April 2014); Jianyi Piao and Zhipei Li "chaoxian 'tuobeizhe' wenti de guojihua yanbian jiqi yingxiang [The Internationalization of the Issue of North Korean 'Escapees' and Its Influence]" (13 August 2012) China Network for the Asian-Pacific Research $<$ http://iaps.cass.cn/news/523644.htm> (accessed 15 August 2013); Yun Cheng "nanmin diwei guoji gongyue ji chaoxian 'nanmin' wenti zhi yanjiu [The International Convention relating to the Status of Refugees and the Issue of North Korean 'Refugees']” (Master dissertation, Dalian Maritime University, 2007).

${ }^{82}$ Hansen Li (ed) "jiena guoji nanmin: chuyu liyi, yuanyu daoyi [Acceptance of International Refugees: out of Interest, Originated in Humanity]" (27 February 2012) China Network Television $<$ http://news.cntv.cn/special/thinkagain/refugee/index.shtml $>$ (accessed 28 April 2014).
} 
Chart 4 What do you Think of Refugees?

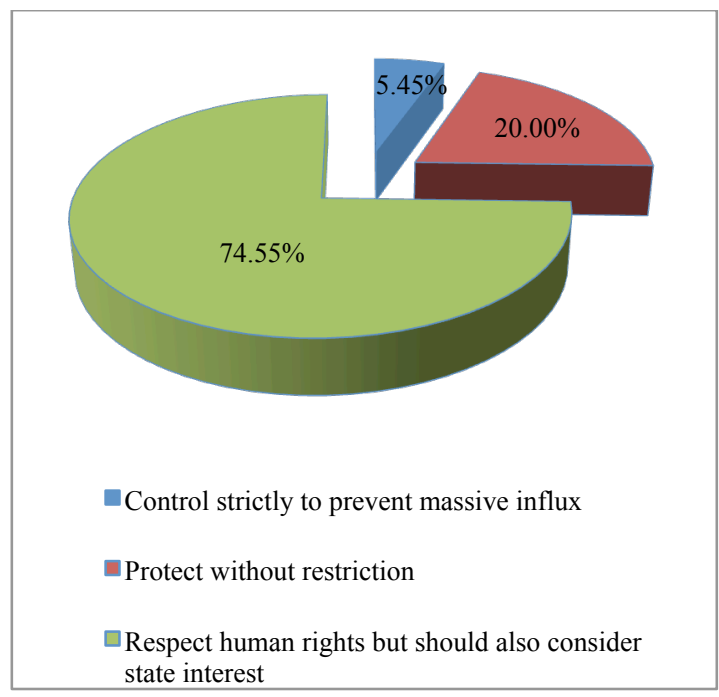

Chart 5 What do you Think of Illegal Border Crossers?

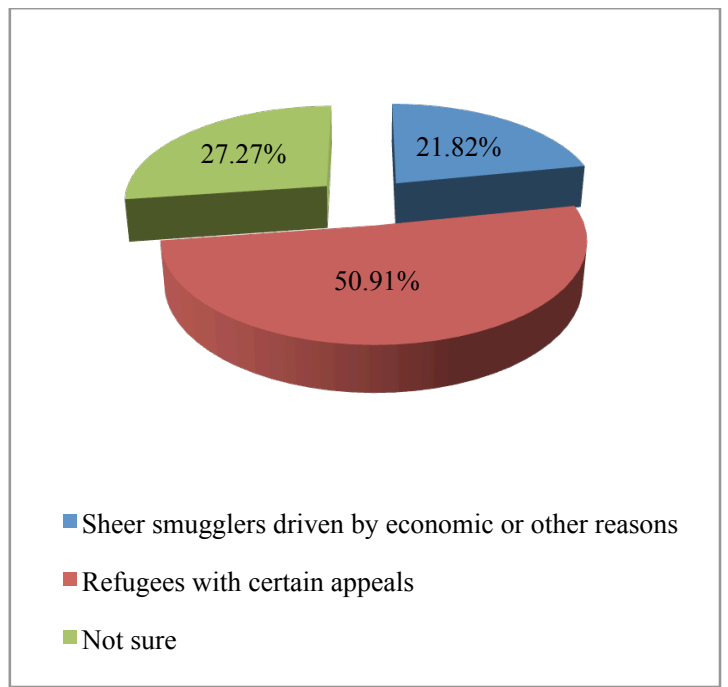

Although the number of participating readers is relatively small, ${ }^{83}$ the results of the survey, which is probably the first of its kind in China, show, to some extent, the sympathy and tolerance of Chinese society for refugees and asylum seekers. Nearly three quarters of the participating readers agreed that refugees' human rights should be protected but China's State interest should also be taken into consideration. In comparison, supporters for strict control of refugee inflows were less than 5.5 per cent of all participants, only about one quarter of those who supported refugee protection without restriction. More than half of the participating readers viewed illegal border crossers as refugees, despite Chinese authorities' strong and persistent position on labelling North Korean escapees as illegal border crossers and illegal economic migrants and denying them refugee status. Those who viewed illegal border crossers as smugglers were 5.45 per cent fewer than those were not sure about their view of illegal border crossers.

The relaxation of control on refugee-related publications reflects China's growing interest in and tolerance of refugees on its soil. However, there has never been any in-depth debate or discussion on refugee issues that involves a wider Chinese audience.

This is mainly because refugees remain a sensitive topic in China. ${ }^{84}$ Where does the sensitivity come from? First, China still remians a source of refugees and asylum seekers. Chinese nationals seeking asylum in Western countries were often used by Western media to criticise China's human rights conditions. In particular, since ethnic Tibetans and Uighurs are among the Chinese nationals seeking asylum in other countries, the Chinese government probably regards refugee issues as linked to the highly sensitive religious and ethnic issues in Tibet and Xinjiang

\footnotetext{
${ }^{83}$ The results are based on 56 votes for each question as of 12 February 2014.

${ }^{84}$ Liu, above n 15, at 91; Lihong Lan and Xiuxia Shi "Reflection on the Latest Progress in Chinese Legislation on International Migration" (2013) 8(3) Frontiers of Law in China 618 at 635.
} 
Autonomous Regions in China. China has reportedly requested other countries to send back Chinese asylum seekers. ${ }^{85}$

It is worth mentioning that Chinese refugees and asylum seekers in third countries are generally not reported or discussed in China. The occasional media coverage of high-profile Chinese asylum seekers overseas probably has only generated negative feelings towards refugees in Chinese society. The story of Lai Changxing is a case in point. Lai was a businessman in Xiamen, Fujian Province in southern China, who was charged with bribery and smuggling by the Chinese government. Lai fled to Canada in 1999 and applied for refugee status there. Though his case was eventually turned down by Canadian authorities and he was extradited to China, ${ }^{86}$ the procedure took more than 10 years, during which Lai was able to enjoy a comfortable life in his luxury home in Vancouver, Canada. Had Lai successfully claimed refugee status in Canada, he would have been able to escape Chinese judicial procedures for his criminal offences in China. This might have given Chinese society the impression that the refugee protection system was helping criminals and betrayers of China like Lai.

Ironically, while China's efforts in locally integrating the Indochinese refugees were largely neglected by the international community, its deportation of North Korean escapees was caught in the spotlight in recent years and attracted international criticism. This probably results in China's negative and defensive attitude towards domestic refugee issues.

Another reason why ordinary Chinese are unfamiliar with refugees is that they lack interaction with refugees. As the Indochinese refugees live in six provinces and autonomous regions in South and Southwest China and UNHCR refugees are not allowed to work or attend Chinese universities or high schools, and need approval to travel, ${ }^{87}$ most Chinese have never met or known any refugee.

Nevertheless, Chinese communities that have contact with refugees and asylum seekers have demonstrated a tradition of hospitality. The Indochinese refugees were generously hosted by local residents upon their arrival at the Chinese border, and later were well accepted by local communities when they were resettled. ${ }^{88}$ Korean Chinese communities in Northeast China were reported to have been sheltering and assisting North Korean escapees in the region despite disapproval from the government. ${ }^{89}$ The displaced Kokangs were well received by residents in China's Yunnan Province; many Chinese citizens not only called for support to the displaced

\footnotetext{
${ }^{85}$ Jamil Anderlini "China presses Thailand to return Uighur refugees" Financial Times (Online ed, 3 April 2014), available at <http://www.ft.com/intl/cms/s/0/35bbf33a-bb1d-11e3-948c-00144feabdc0.html\#axzz3I4pBroPA> (accessed 20 June 2014).

${ }^{86}$ For more information of Lai's case, see for example, "Canada to Deport Chinese Fugitive Lai Changxing" (22 July 2011) BBC <http://www.bbc.co.uk/news/world-us-canada-14245141> (accessed 28 April 2014); "Why Lai Changxing's Appeal to Canadian Court Rejected?" People's Daily (online ed, Beijing, 9 February 2004), available at <http://english.peopledaily.com.cn/200402/09/eng20040209_134341.shtml> (accessed 28 April 2014).

${ }^{87}$ Lin, above $\mathrm{n} 55$.

${ }^{88}$ See eg Liang, above n 32, at 277.

${ }^{89}$ See eg Haggard and Noland, above n 59, at 34; Ju Hui Judy Han "Beyond Safe Haven - A Critique of Christian Custody of North Korean Migrants in China" (2013) 45(4) Critical Asian Studies 533; James D Seymour "China: Background Paper on the Situation of North Koreans in China" (2005) Refworld $<$ http://www.refworld.org/docid/4231d11d4.html $>$ (accessed 28 April 2014) at 15.
} 
Kokangs, but also volunteered at the camps set up for the displaced Kokangs. ${ }^{90}$ During the Kachin influx, Chinese civilians, both ethnic Jingpo and Han, from Yunnan Province and other parts of China, helped the displaced Kachins in many ways, such as providing accommodation, donating clothes and helping in negotiations with Chinese government officials to optimise the displaced Kachins' chance to stay in China. ${ }^{91}$

Because of the high sensitivity of the refugee topic in China and the resulting tight government control, except UNHCR and the Chinese government's Office of Reception and Settlement of Indochinese Refugees (ORSIR), which support the Indochinese refugees, few organisations assisting or advocating for refugees exist in China. A small number of non-governmental organisations (NGO) and religious groups operate quietly or underground, helping the North Korean escapees or the displaced Kachins in China. There are no NGOs or law firms providing legal assistance relating to refugee status application in China. ${ }^{92}$ Consequently, refugees in China have little support and few means to make their voices heard in the Chinese society.

\section{Conclusion}

China is in a transitional position from a source country of refugees and asylum seekers to a country as both the source and the host of refugees and asylum seekers. This transitional position is crucial for understanding China's law and policy on refugee status.

China has had limited experience in handling refugees and asylum seekers. Such experience has occurred mainly around large-scale inflows from neighbouring countries. This characteristic of China's experience with refugees, coupled with the traditional mistrust of foreigners in general, has contributed to China's perception of refugees as a threat to national security and stability.

The growing number of refugees and other displaced foreigners calls for regulated, effective refugee recognition and protection mechanisms in China. Presently, persons with refugee status in China generally fall into two categories: the Indochinese refugees and the UNHCR refugees. The differentiated treatment of these two subsets of refugees in China is not in line with the principle of non-discrimination set forth in art 3 of the Convention. ${ }^{93}$ Displaced foreigners who do not have refugee status in China also fall into two categories: those who have access to the RSD services of the Beijing Office of UNHCR, and those to whom China restricts UNHCR's access. Repatriation of the latter subset of displaced foreigners in China, ie the North Korean

\footnotetext{
${ }^{90}$ See eg Piaobotanggula "guogan, jinye wumian weini qidao [Kokang, Praying for You in This Sleepless Night]" (28 August 2009) Tianya Forum <http://bbs.tianya.cn/post-news-141112-1.shtml> (accessed 14 February 2014); "jiaoda zhiyuanzhe zai Yunnan bianchun anquan duguo guogan zhanshi [Jiaotong University Volunteers Survived Kokang War]" (24 September 2009) Shanghai Jiaotong University $<$ http://topics.sjtu.edu.cn/newsnet/shownews.php?id=22669> (accessed 23 April 2014).

${ }^{91}$ Interviews conducted by the author (April 2013). See Chapter VI for more information.

92 "We have not yet identified any NGO or law firm that is offering refugees legal assistance in China; in fact, we understand that the government does not allow refugee-assisting NGOs to operate." "China Pro Bono Directory" Fahamu Refugee Programme <http://www.refugeelegalaidinformation.org/china-pro-bono-directory $>$ (accessed 17 April 2014).

${ }^{93}$ See ch II.
} 
escapees and the ethnic Kachins, raises the question of full compliance with the obligation of non-refoulement under art 33 of the Convention. ${ }^{94}$

${ }^{94}$ See ch II. 


\section{Chapter II The Refugee Concept under International law}

Everyone has the right to seek and to enjoy in other countries asylum from persecution.

- Article 14(1), Universal Declaration of Human Rights

This chapter introduces the concept of a refugee in international law. Aiming to provide a background for the discussion in the following chapters on China's recognition or nonrecognition of refugee status of displaced foreigners on its territory, it primarily focuses on the Convention and Protocol, to which China is a party, with an emphasis on issues relating to the Chinese context. This chapter also discusses the refugee for purpose of the UN and developments of the refugee definition in regional law, with an emphasis on the Asian region.

\section{Refugeehood and Refugee Status}

The term "refugee" in the sense of international law is primarily defined in the Convention and Protocol, the most widely ratified international legal instruments relating to refugees. It is also defined, for the purposes of the UN, in the Statute of the Office of the United Nations High Commissioner for Refugees (UNHCR Statute), which sets out the mandate of the UN's refugee agency. In addition, several regional arrangements, such as the 1969 Organization of African Unity Convention Governing the Specific Aspects of Refugee Problems in Africa (OAU Convention), the 1984 Cartagena Declaration on Refugees, Colloquium on the International Protection of Refugees in Central America, Mexico and Panama (Cartagena Declaration), and Directive 2011/95/EU of the European Parliament and of the Council on standards for the qualification of third-country nationals or stateless persons as beneficiaries of international protection, for a uniform status for refugees or for persons eligible for subsidiary protection, and for the content of the protection granted (EU Qualification Directive), and the Bangkok Principles concerning the Status and Treatment of Refugees (Bangkok Principles), provide a definition of a refugee at the regional level.

The refugee definition in these instruments is divergent and subject to interpretation when applied domestically by States. Shacknove has insightfully pointed out that "[a] conception of 'refugee' is not, strictly speaking, a definition. There are in fact dozens of definitions in effect within various jurisdictions". ${ }^{95} \mathrm{He}$ has noted that there is, however, something essential and universal about refugeehood: ${ }^{96}$ the bond between the citizen and the State, which constitutes the normal basis of society, has been severed in the case of the refugee. ${ }^{97}$ Similarly, Grahl-Madsen has noted that "[ $t$ ]he concept of 'refugee' has no single, simple meaning"; he has also recognised

\footnotetext{
95 Andrew E Shacknove "Who is a Refugee?" (1985) 95(2) Ethics 274 at 275. Shacknove noted that most States "have their own municipal definitions, the majority of which follow the construction of the UN [Refugee] Convention", at 275.

${ }^{96}$ Shacknove, above n 95, at 275.

${ }^{97}$ At 275 and 278.
} 
that certain characteristics set refugees apart from other persons and that "the crux of the matter is that the relationship between the State and the refugee has turned sour for political reasons". 98

It is generally accepted that refugee law is a system principally concerned with providing a remedy to a fundamental breakdown in the relationship between individuals and their State. ${ }^{99}$ Refugee status affords its beneficiaries surrogate protection in the absence of national protection usually provided by the country of their nationality or, in the case of stateless persons, the country of their habitual residence. ${ }^{100}$

Hathaway and Foster have observed that "[r]efugee law may be the most powerful international human rights mechanism". ${ }^{101}$ On the one hand, a person who is refugee at international law is entitled to claim a wide range of internationally binding rights in more than 100 countries which are parties to relevant international or regional refugee instruments. ${ }^{102}$ On the other, as GoodwinGill and McAdam have noted, the international legal status of refugees necessarily entails legal consequences for States, the most important of which is to respect the principle of nonrefoulement. ${ }^{103}$

According to UNHCR, recognition of refugee status by States is only declaratory: ${ }^{104}$

[a] person is a refugee within the meaning of the 1951 Convention as soon as he fulfils the criteria contained in the definition. This would necessarily occur prior to the time at which his refugee status is formally determined. Recognition of his refugee status does not therefore make him a refugee but declares him to be one. He does not become a refugee because of recognition, but is recognized because he is a refugee.

This position of UNHCR has been generally accepted by scholars. ${ }^{105}$ For example, Hathaway and Foster have noted that "as UNHCR has insisted, refugee status is not a status that is granted

\footnotetext{
${ }^{98}$ Atle Grahl-Madsen "International Refugee Law Today and Tomorrow" (1982) 20 Archiv des Völkerrechts 411, at 418 .

${ }^{99}$ See eg James C Hathaway and Michelle Foster The Law of Refugee Status (2nd ed, Cambridge University Press, Cambridge, 2014), at 288; Nïraj Nathwani Rethinking Refugee Law (Martinus Nijhoff, the Hague, 2003), at 70; Ward v Canada (Attorney General) (1993) 2 SCR 689, at 709; Horvath v Secretary of State for the Home Department [2001] 1 AC 489 (HL), at 495.

${ }^{100}$ UNHCR "Interpreting Article 1 of the 1951 Convention Relating to the Status of Refugees" (2001) UNHCR $<$ http://www.unhcr.org/refworld/docid/3b20a3914.html > (accessed 20 April 2014), at [52].

${ }^{101}$ Hathaway and Foster, above n 99, at 1.

${ }^{102}$ At 1.

${ }^{103}$ Guy S Goodwin-Gill and Jane McAdam The Refugee in International Law (3rd ed, Oxford University Press, Oxford, 2007), at 1.

${ }^{104}$ UNHCR Handbook on Procedures and Criteria for Determining Refugee Status under the 1951 Convention and the 1967 Protocol relating to the Status of Refugees, HCR/IP/4/Eng/REV.1 (reedited January 1992), at [28].

${ }^{105}$ Pirkko Kourula Broadening the Edges: Refugee Definition and International Protection Revisited (Martinus Nijhoff Publishers, The Hague, 1997), at 39. See also works supporting UNHCR's view, eg Grahl-Madsen, above $n$ 98, at 428; Andreas Zimmermann and Claudia Mahlet "Article 1 A, para. 21951 Convention" in Andreas Zimmermann (ed) The 1951 Convention Relating to the Status of Refugees and its 1967 Protocol: A Commentary (Oxford University Press, Oxford, 2011) 281 at 299; Goodwin-Gill and McAdam, above n 103, at 51; Hathaway and Foster, above n 99, at 1.
} 
by states; it is rather simply recognized by them". ${ }^{106}$ An implication of this argument, as put forward by Hathaway and Foster, is that the entitlement to the rights provided relevant refugee instruments - "including not only critical civil rights, but also socio-economic rights and rights that enable pursuit of a solution to refugeehood" - persists until and unless the person concerned is found not to be a refugee. ${ }^{107}$

Kneebone has noted that "in recognition of the 'declaratory' nature of refugee status, some basic rights adhere under the Refugee Convention to all refugees, irrespective of status." 108 She has further noted that these basic rights include the rights against refoulement and discrimination as to race, religion or country of origin, the right against penalisation for unlawful presence in the host country, and the right of free access to courts. ${ }^{109}$

Goodwin-Gill and McAdam, recognising that in principle "determination of refugee status is declaratory, rather than constitutive", ${ }^{110}$ have nonetheless pointed out that in practical termss: ${ }^{111}$

the legal consequences which flow from the formal definition of refugee status are necessarily predicated upon determination by some or other authority that the individual or group in question satisfies the relevant legal criteria.

Grahl-Madsen has also observed, ${ }^{112}$

[i]t follows from the declaratory nature of the act of recognition that refugees are refugees also before they are recognised, but until recognition takes place, they are in a kind of limbo, ... With many people in the "pipelines" for protracted periods of time, we are not only faced with enormous numbers, but it is difficult to tell who are 'de facto refugees' and who are not.

UNHCR also acknowledged that "RSD [refugee status determination] is usually the 'entry door' to international protection and durable solution." "113 Indeed, although a person is a refugee as soon as that person fulfils the criteria contained in the applicable refugee definition, when or

\footnotetext{
${ }^{106}$ Hathaway and Foster, above $\mathrm{n} 99$, at 1.

107 James C Hathaway The Rights of Refugees under International Law (Cambridge University Press, Cambridge, 2005), at 11 .

${ }^{108}$ Susan Kneebone "Introduction: Refugees and Asylum Seekers in the International Context - Rights and Realities" in Susan Kneebone (ed) Refugees, Asylum Seekers and the Rule of Law Comparative Perspectives (Cambridge University Press, Cambridge, 2009) 1, at 7.

${ }^{109}$ Kneebone, above $\mathrm{n}$ 108, at 7: "These include the negative rights against refoulement (Art. 33) and discrimination as to 'race, religion or country of origin' (Art. 3). To this can be added Article 31, the non-penalization provision which applies to refugees 'unlawfully' in the country; that is, those who have entered or attempted to enter the territory without permission.22 Additionally all refugees are entitled to free access to courts of law 'on the territory of all Contracting States' (Art. 16(1))".

${ }^{110}$ Goodwin-Gill and McAdam, above n 103, at 51.

${ }^{111}$ Goodwin-Gill and McAdam, above n 103, at 51, with footnote on the term "legal consequences".

112 Grahl-Madsen, above n 98, at 428.

${ }^{113}$ UNHCR “APC Regional Workshop - Refugee Status Determination (RSD) Discussion Paper: Refugee Status Determination Processes and Procedures in the Region" (10 March 2009), at [28], emphasis added.
} 
whether "he fulfils the criteria contained in the definition" has hardly been self-evident and the claims that a person "fulfils the criteria contained in the definition" necessarily comes from one stakeholder or another, be it the refugee claimant, the State in which the refugee claimant requests asylum, UNHCR, academics, or other States which are not the host country of the refugee claimant.

Furthermore, the question of whether or when a person "fulfils the criteria contained in the definition" has never been an easy one to agree on between and among relevant stakeholders. ${ }^{114}$ Despite the wide acceptance of the Convention and Protocol, the interpretation of the Convention varies from country to country, even within countries. ${ }^{115}$ This reality is most vividly demonstrated by the Zaoui case, where an Algerian asylum seeker, having been denied refugee status in Spain and Belgium (twice), was declared a refugee by the New Zealand Refugee Status Appeal Authority. ${ }^{116}$ North and Chia have also forthrightly pointed out that "a refugee in Canada may not be a refugee in the United States, and vice versa". ${ }^{117}$

Within a certain jurisdiction, as a matter of binding decisions, the host State and/or UNHCR have performed the function of determining whether a person or a group satisfies relevant legal criteria for refugee status.

\section{The Definition of a Refugee under the 1951 Convention relating to the Status of Refugees and its 1967 Protocol}

\section{A The 1951 Convention relating to the Status of Refugees and its 1967 Protocol \\ $1 \quad$ Status of the 1951 Convention relating to the Status of Refugees and its 1967 Protocol}

The 1951 Convention relating to the Status of Refugees and its 1967 Protocol are the cornerstone of the international refugee protection regime and the key international legal documents in defining who is a refugee. Grounded in article 14 of the 1948 Universal Human Rights Declaration, ${ }^{118}$ which recognises a person's right to seek and enjoy asylum from persecution, the Convention was adopted in 1951 and entered into force in 1954. The Convention defines the term "refugee", and sets a minimum standard for the treatment of

\footnotetext{
${ }^{114}$ For general discussions on this topic, see eg Hathaway and Foster, above n 99; Goodwin-Gill and McAdam, above n 103; Grahl-Madsen, above n 98; Shacknove, above n 95; Jean-Yves Carlier et al (eds) Who is a Refugee - A Comparative Case Law Studies (Kluwer Law International, the Hague, 1997); Kourula, above n 105; Jerzy Sztucki "Who is a Refugee? The Convention Definition: Universal or Obsolete?" in Nicholson and Twomey (ed) Refugee Rights and Realities (Cambridge University Press, Cambridge, 1999) 55.

${ }^{115}$ Anthony M North and Joyce Chia "Towards Convergence in the Interpretation of the Refugee Convention: A Proposal for the Establishment of an International Judicial Commission for Refugees" in Jane McAdam (ed) Forced Migration, Human Rights and Security (Hart Publishing, Oxford, 2008) 225, at 225; Mary Crock, Ben Saul and Azadeh Dastyari Future Seekers II (The Federation Press, Annandale (NSW), 2006) at 86. See also part II C of this chapter.

${ }^{116}$ Zaoui NZRSAA Refugee Appeal No 74540, 1 August 2003. France, Switzerland, Belgium, and New Zealand are parties of the 1951 Convention relating to the Status of Refugees (the Convention).

${ }_{117}^{17}$ North and Chia, above $\mathrm{n} 115$, at 225 .

${ }^{118}$ UNHCR "Introductory Note to the Convention and Protocol relating to the Status of Refugees" (2011) UNHCR $<$ www.unhcr.org/3b66c2aa10.pdf $>$ (accessed 16 October 2014), at 1.
} 
refugees. ${ }^{119}$ Initially drafted in the aftermath of the Second World War in response to the mass displacement in Europe, ${ }^{120}$ the Convention originally was limited in scope to persons fleeing events occurring prior to 1 January 1951 and allowed contracting parties to further limit the application of the Convention to persons fleeing events occurring in Europe prior to 1 January 1951 (art 1B(1)). In 1967, the Protocol was adopted to remove these temporal and geographic limitations of the Convention.

As of April 2014, there were 145 State parties to the Convention and 146 State parties to the Protocol. China has been a party to the Convention and Protocol since September 1982. In December 2011, UN member States reaffirmed their recognition of the "enduring value and relevance" of the Convention and Protocol and their importance as the "foundation of the international refugee protection regime". ${ }^{121}$

Rights of Refugees

The Convention lays down a number of fundamental principles of refugee protection, most notably non-refoulement, non-discrimination, and non-penalisation. ${ }^{122}$ The principle of nonrefoulement, found in art 33(1) of the Convention, prohibits State parties from returning refugees in any manner whatsoever to any place where their life or freedom would be threatened. This principle not only requires the State not to deport refugees on its territory, but also requires the State not to push back refugees at its border. The principle of non-refoulement is a nonderogatory obligation of contracting States; ${ }^{123}$ State parties to the Convention are not allowed to make any reservation to it (art 42 of the Convention). The principle of non-discrimination, as set forth in art 3 of the Convention, prohibits States from discrimination between and among refugees on the basis of race, religion, and country of origin when applying the Convention. ${ }^{124}$ According to the principle of non-penalisation under art 31(1) of the Convention, States shall not penalise refugees for illegal entry or stay provided that refugees present themselves without delay to the authorities and show good cause for their illegal entry or stay.

The Convention and Protocol also afford a series of rights for refugees, such as freedom from arbitrary detention, freedom from penalisation for illegal entry, freedom from expulsion, the right to work, the right to public education, the right of free movement, the right to access courts,

\footnotetext{
${ }^{119}$ UNHCR Refugee Protection: A Guide to International Refugee Law (UNHCR and Inter-Parliamentary Union, Geneva, 2001) at 8.

${ }^{120}$ Gil Loescher Beyond Charity: International Cooperation and the Global Refugee Crisis (Oxford University Press, Oxford, 1993) at 57.

${ }^{121}$ Ministerial Communiqué, HCR/MINCOMMS/2011/6 (8 December 2011), at [2], cited from UNHCR The State of the World's Refugees 2012: In Search of Solidarity (Oxford University Press, Oxford, 2012), at 37.

122 UNHCR, above n 118.

${ }^{123}$ UNHCR Excom General Conclusion on International Protection, No. 79 (XLVII) - 1996 (11 October 1996), at (i); UN General Assembly Resolution 51/75 Office of the United Nations High Commissioner for Refugees, A/RES/51/75 (12 February 1997), at [3]; UN General Assembly Resolution 52/132 Human Rights and Mass Exodux, A/RES/52/132 (27 February 1998), Preamble. However, Goodwin-Gill and McAdam have noted that "the (legal) obligation to respect this principle, independent and compelling as it is, may be difficult to isolate from the (political) options which governs the availability of solutions." Goodwin-Gill and McAdam, above n 103, at 1.

${ }^{124}$ Through the development of international human rights law, State parties are also required to apply the Convention without discrimination on the basis of sex, age, disability, sexuality, or other prohibited grounds. UNHCR, above n 118; Hathaway, above n 107, at 248.
} 
and the right of resolution. It is important to understand that the Convention and Protocol only serve as statements of the minimum rights of the refugees; State parties must not provide less protection, but may provide wider protection to refugees or extend their protection to nonrefugees.

3 Limitations of the 1951 Convention relating to the Status of Refugees and its 1967 Protocol

The Convention and Protocol are not without limitations. Most notably, the Convention and Protocol do not impose on State parties a legal obligation to grant asylum. Although there are references to asylum in the Final Act of the Conference of Plenipotentiaries and in the Preamble to the Convention, the Convention does not impose an obligation upon States to grant asylum to refugees. ${ }^{125}$

Secondly, the Convention and Protocol do not establish any particular procedure for RSD or admission of refugees to be followed by States. They therefore leave to States the choice of means as to implementation at the national level. ${ }^{126}$

Thirdly, the Convention and the Protocol do not establish an effective supervision mechanism. UNHCR is given the task to supervise the implementation of the Convention and Protocol. ${ }^{127}$ Nevertheless, unlike treaty supervisory mechanisms formed under the Convention against Torture or the 1989 Convention on the Rights of the Child, UNHCR does not have the function of reviewing State reports or determining individual or inter-State complaints. ${ }^{128}$ Additionally, although according to art 38 of the Convention the International Court of Justice (ICJ) is the relevant forum for settling any dispute between States relating to the interpretation and application of the Convention, this jurisdiction of ICJ has never been invoked. ${ }^{129}$

$B \quad$ The Definition of a Refugee under the 1951 Convention relating to the Status of Refugees and its 1967 Protocol

The Convention provides a general definition of a refugees under art 1A(2) (the Convention Refugee Definition), ${ }^{130}$ which, read together with the Protocol, defines a refugee as any person who:

\footnotetext{
${ }^{125}$ UNHCR, above n 104, at [25]: "the granting of asylum is not dealt with in the 1951 Convention or the 1967 Protocol"; Minister for Immigration and Multicultural Affairs $v$ Khawar [2002] HCA 14, Mc Hugh and Gummow JJ: "the term 'asylum' does not appear in the main body of the text of the [Refugee] Convention; the Convention does not impose an obligation upon contracting states to grant asylum or a right to settle in those states to refugees arriving at their borders".

${ }^{126}$ Goodwin-Gill and McAdam, above n 103, at 54.

${ }^{127}$ Preamble of the Convention.

${ }^{128}$ Guy S Goodwin-Gill "Convention Relating to the Status of Refugees \& Protocol Relating to the Status of Refugees" (2008) UN Audiovisual Library of International Law <http://legal.un.org/avl/ha/prsr/prsr.html $>$ (accessed 28 April 2014).

${ }^{129}$ Katie O'Byrne "Is There a Need for Better Supervision of the Convention?" (2013) 26(3) Journal of Refugee Studies 330 at 333.

${ }^{130}$ Article $1 \mathrm{~A}(1)$ deals with persons considered to be refugees under the provisions of international instruments preceding the Convention.
} 
owing to well-founded fear of being persecuted for reasons of race, religion, nationality, membership of a particular social group or political opinion, is outside the country of his nationality and is unable or, owing to such fear, is unwilling to avail himself of the protection of that country; or who, not having a nationality and being outside the country of his former habitual residence as a result of such events, is unable or, owing to such fear, is unwilling to return to it.

Central to this definition is the "persecution" criterion, ie it is owing to well-founded fear of persecution that a person is unable or unwilling to avail himself or herself of the protection of the country of origin. The focus is the risk of persecution. Persecution does not have to have happened, but there should be a real chance of persecution.

Another characteristic of the Convention Refugee Definition is that the reasons for fear of persecution are limited to five grounds, namely race, religion, nationality, membership of a particular social group and political opinion. To qualify as a refugee, a person must establish that there is a nexus between the fear of persecution and one or more of the enumerated grounds.

A third feature of the Convention Definition is that it requires a refugee to be outside the country of nationality or, in the case of a stateless person, outside the country of habitual residence. This means a person must cross an international border to qualify as a refugee.

In addition to stipulating who is a refugee, the Convention also specifies who is not. Those who do not need or deserve includes persons protected or assisted by other UN organs or agencies (art 1D), persons protected by the State of their residence (art 1E), persons who committed a crime against peace or humanity, a war crime, or a serious non-political crime (art 1F), and persons who has been guilty of acts contrary to the principles and purposes of the UN (art 1F).

\section{Interpretation and Application of the Convention Refugee Definition}

\section{$1 \quad$ General Principles}

The interpretation of the Convention Refugee Definition is a matter of much discussion. Although according to Lord Steyn "there can be only one true interpretation of the treaty" and each State "must search, untrammelled by notions of its national legal culture, for the true autonomous and international meaning of the treaty", ${ }^{131}$ virtually every word of the core phrases of the Convention Refugee Definition has been subject to interpretive dispute. ${ }^{132}$

Not only does interpretation of the Convention Refugee Definition raise many complex issues, but there is no single authoritative entity acting as the final arbiter on issues of interpretation of the Convention. ${ }^{133}$ McAdam has forthrightly pointed out that there is no uniform international practice or single interpretation of the Convention. ${ }^{134}$ As mentioned above, the ICJ is the

\footnotetext{
${ }^{131} R v$ Secretary of State for the Home Department; Ex parte Adan [2001] 2 AC 477 (HL), at 516 (Lord Steyn).

${ }^{132}$ Daniel J Steinbock "The Refugee Definition as Law: Issues of Interpretation" in Frances Nicholson and Patrick Twomey (eds) Refugee Rights and Realities: Evolving International Concepts and Regimes (Cambridge University Press, Cambridge, 1999) 13 at 14.

${ }^{133}$ Hathaway and Foster, above $n$ 99, at 3.

${ }^{134}$ McAdam, above n 138, at 77.
} 
relevant forum for settlement of disputes relating to the interpretation and application of the Convention between State parties, ${ }^{135}$ but this mechanism has never been invoked, ${ }^{136}$ and the prospect of it being used is remote. ${ }^{137}$ UNHCR has a supervisory role in relation to the implementation and application of the Convention, however, it does not have the authority to mandate any particular interpretation of the Convention Refugee Definition. ${ }^{138}$

As Hathaway and Foster have observed, as a matter of binding law, the task of determining the Convention's "true autonomous and international meaning" has fallen principally on domestic decision-makers - officials, specialist tribunals, and courts. ${ }^{139}$ Goodwin-Gill has also pointed out that, in the absence of a formally established treaty supervisory body, "it is the totality of the state parties themselves which are competent to provide authoritative interpretation". ${ }^{140}$

As observed by the International Law Commission, interpretation of treaties is "to some extent an art, not an exact science". ${ }^{141}$ According to the Vienna Convention on the Law of Treaties, a "treaty shall be interpreted in good faith in accordance with the ordinary meaning to be given to the terms of the treaty in their context and in the light of its object and purpose". ${ }^{142}$ Further, the Vienna Convention on the Law of Treaties requires States to take into account subsequent agreement and practice as well as relevant rules in international law when interpreting a treaty. ${ }^{143}$

The Convention has been acknowledged as a "living instrument". ${ }^{144}$ The meaning of the core phrases of the Convention Refugee Definition, as part of a "living instrument", has evolved since the inception of the Convention in 1951, although the Convention Refugee Definition has sometimes been criticised as outdated. ${ }^{145}$ The evolving interpretation of the Convention refugee

\footnotetext{
${ }^{135}$ Article 38 of the Convention: "Any dispute between parties to this Convention relating to its interpretation or application, which cannot be settled by other means, shall be referred to the International Court of Justice at the request of any one of the parties to the dispute".

${ }^{136}$ O'Byrne, above n 129, at 333 .

${ }^{137}$ North and Chia, above $\mathrm{n} 115$, at 240 .

${ }^{138}$ Jane McAdam "Interpretation of the 1951 Convention" in Andreas Zimmermann (ed) The 1951 Convention relating to the Status of Refugees and its 1967 Protocol: A Commentary (Oxford University Press, Oxford, 2011) 75, at 79; Hathaway and Foster, above n 99, at 3.

${ }^{139}$ Hathaway and Foster, above $\mathrm{n} 99$, at 3.

${ }^{140}$ Guy S Goodwin-Gill "The Search for the One, True Meaning...” in Guy Goodwin-Gill and Helen Lambert (eds) The Limits of Transnational Law: Refugee Law, Policy Harmonization and Judicial Dialogue in the European Union (Cambridge University Press, Cambridge, 2010), at 207 in footnote 8.

${ }^{141}$ International Law Commission "Reports of the Commission to the General Assembly" (1964) vol II International Law Commission Yearbook 200 at [5], cited from McAdam, above n 138, at 82, further references cited there.

${ }^{142}$ Art 31(1).

${ }^{143}$ Art 31(3): "3.There shall be taken into account, together with the context: (a) any subsequent agreement between the parties regarding the interpretation of the treaty or the application of its provisions; (b) any subsequent practice in the application of the treaty which establishes the agreement of the parties regarding its interpretation; (c) any relevant rules of international law applicable in the relations between the parties".

${ }^{144}$ Susan Kneebone and Maria O'Sullivan "Article 1 C" in Andreas Zimmermann (ed) The 1951 Convention relating to the Status of Refugees and its 1967 Protocol: A Commentary (Oxford University Press, Oxford, 2011) 481 at 531 , further references cited there.

${ }^{145}$ Guy S Goodwin-Gill "The Refugees Convention: Why not Scrap it?" (2005) Chatham House $<$ https://www.chathamhouse.org/sites/files/chathamhouse/public/Research/International\%20Law/ilp201005.pdf $>$ (accessed 20 June 2013), at 1.
} 
definition has been extensively explored in scholarly writings. ${ }^{146}$ One pertinent example is the notion of "membership of a particular social groups", which has developed significantly through expansive interpretation. ${ }^{147}$ It is also well-known that the interpretation of "persecution" has been influenced by the development of international human rights law and humanitarian law, in particular the Convention against Torture and Other Cruel, Inhuman or Degrading Treatment or Punishment (the Convention against Torture) (adopted 10 December 1984, entered into force 26 June 1987), after the birth of the Convention. ${ }^{148}$

It should be noted that the debate on where the boundaries of the Convention Refugee Definition should lie, which has lasted for decades, continues. While UNHCR has recently observed that, if the 1951 Refugee Convention and its 1967 Protocol were to be properly applied, they would address most international protection needs, ${ }^{149}$ Steinbock has reminded us that while the identified purposes of the Convention clearly serve to protect important human rights, they are not co-extensive with the entire body of international human rights law. ${ }^{150}$

Although this is not the right place for a thorough discussion on the interpretation issues of the Convention Refugee Definition, it may be useful to refer to what has been pointed out by Shacknove: ${ }^{151}$

an overly narrow conception of "refugee" will contribute to the denial of international protection to countless people in desperate circumstances whose claim to assistance is impeccable; conversely, an overly inclusive conception is also morally suspect and will financially exhaust relief programmes and impune the credibility of the refugee's privileged position among host populations, whose support is crucial for the viability of international assistance programmes.

\section{Application of the Convention Refugee Definition in Mass Influx Situations}

The phenomenon of large-scale influx of refugees, commonly known as "mass influx", is a dominant feature of the refugee problem today worldwide. ${ }^{152}$ The term "mass influx" does not appear in the Convention or the Protocol. As noted by Durieux and McAdam, there is no precise

\footnotetext{
${ }^{146}$ See generally Hathaway and Foster, above n 99; UNHCR, above n 104; Goodwin-Gill and McAdam, above n 103; Andreas Zimmermann (ed) The 1951 Convention Relating to the Status of Refugees and its 1967 Protocol: A Commentary (Oxford University Press, Oxford, 2011); Grahl-Madsen, above n 98.

${ }^{147}$ See eg Hathaway and Foster, above n 99, at ch 5.9; Zimmermann and Mahler, above n 105, at pt XI.

${ }^{148}$ See eg Goodwin-Gill and McAdam, above n 103, at ch 3.5; Hathaway and Foster, above n 99, at ch 3.

${ }^{149}$ UNHCR "Safe At Last? Law and practice in selected EU Member States with respect to asylum-seekers fleeing indiscriminate violence" (Geneva, July 2011), available at UNHCR <http://www.refworld.org/cgi$\mathrm{bin} /$ texis/vtx/rwmain?docid=4e2ee0022> (accessed 8 October 2014), at 9.

${ }^{150}$ Steinbock, above $\mathrm{n} 132$, at 35 .

${ }^{151}$ Shacknove, above $\mathrm{n} 95$, at 276.

152 Bonaventure Rutinwa "Prima Pacie Status and Refugee Protection" (2001) UNHCR New Issues in Refugee Research Working Paper No 69, at 1.
} 
legal definition of the concept of mass influx. ${ }^{153}$ According to UNHCR, a mass influx situation may, inter alia, have some or all of the following features: ${ }^{154}$

(i) considerable numbers of people arriving over an international border; (ii) a rapid rate of arrival; (iii) inadequate absorption or response capacity in host States, particular during emergency; (iv) individual asylum procedures, where they exist, which are unable to deal with the assessment of such large numbers.

Rutinwa has noted that although mass influx situations had existed before the present refugee protection regime was formulated in 1950s, they became a global experience and a prominent issue in refugee policy only in the 1980s and the 1990s. ${ }^{155}$ It has since been a challenge for States to devise appropriate mechanisms to respond to mass influx refugee situations. ${ }^{156}$

The Convention Refugee Definition is often considered primarily individualistic. ${ }^{157}$ It is well known that RSD procedures are generally designed for the determination of individual applications. ${ }^{158}$ In mass influx situations, on the one hand, the large numbers of arrivals usually makes individual refugee status determination impracticable, ${ }^{159}$ on the other, the evident and immediate need for emergency assistance and protection demand an urgent response. ${ }^{160}$

As noted by UNHCR, Jackson, and Durieux and McAdam, there is nothing inherent in the provisions of the Convention or Protocol to preclude the application of the Convention Refugee Definition in mass influx situations, ${ }^{161}$ or in group determination of refugee status. ${ }^{162}$ In fact, the

\footnotetext{
${ }^{153}$ Durieux and McAdam, above n 161, at 17. For further discussion on different opinions on what constitutes a mass influx, see Mathew Albert "Governance and Prima Facie Refugee Status Determination: Clarifying the Boundaries of Temporary Protection, Group Determination, and Mass Influx" (2010) 29(1) Refugee Survey Quarterly 61 at 84-87.

${ }^{154}$ UNHCR Excom Conclusion on International Cooperation and Burden and Responsibility Sharing in Mass Influx Situations, No. 100 (LV) - 2004 (8 October 2004).

${ }^{155}$ Rutinwa, above $\mathrm{n} 153$, at 1.

${ }^{156}$ At 1.

${ }^{157}$ Eg Goodwin-Gill and McAdam, above n 103, at 133; Helene Lambert "The Next Frontier: Expanding Protection in Europe for Victims of Armed Conflict and Indiscriminate Violence" (2013) 25(2) International Journal of Refugee Law 207 at 207;

${ }^{158}$ UNHCR, above n 113, at [27].

${ }^{159}$ UNHCR Protection of Refugees in Mass Influx Situations: Overall Protection Framework, EC/GC/01/4 19 (19 February 2001), at [3].

${ }^{160} \mathrm{UNHCR}$, above $\mathrm{n} 159$, at [3].

${ }^{161}$ UNHCR The Scope of International Protection in Mass Influx, EC/1995/SCP/CRP.3 (2 June 1995), at [12]; UNHCR, above n 159, at [17]; Ivor C Jackson The Refugee Concept in Group Situations (Martinus Nijhoff Publishers, The Hague, 1999), at 2; Jean-François Durieux and Jane McAdam "Non-Refoulement through Time: The Case for a Derogation Clause to the Refugee Convention in Mass Influx Emergencies" (2004) 16(4) International Journal of Refugee Law 4 at 9: "there is a common misperception that the Convention does not apply to mass influx situations because its definition of a refugee is 'essentially individualistic'. Yet the Convention itself contains nothing to suggest its inapplicability in cases of mass influx".

${ }^{162}$ Australian Department of Immigration and Multicultural Affairs "Protection of Refugees in Mass Influx Situations: An Australian Contribution to UNHCR's Global Consultations on International Protection" (2001) Australian Government <http://www.immi.gov.au/media/publications/refugee/unhcr/mass_influx.htm> (accessed 18 October 2013), at [6]: "In our view, volume is not necessarily the critical variable when considering group determination and interim protection and should not outweigh other considerations. These tools may be equally
} 
applicability of the refugee definition in group situations was recognised during the drafting of the Convention. ${ }^{163}$ As pointed out by UNHCR: ${ }^{164}$

The stumbling block has been less the Convention itself and more the individualised processes put in place to implement it, coupled with a perception of the Convention as an instrument of integration.

The traditional response to mass influx situations has been to use prima facie determination of refugee status or acceptance on a group basis, ${ }^{165}$ made on the obvious refugee character of the individuals concerned and the subject circumstances leading to the mass displacement, ${ }^{166}$ without going into any formal, individual determinations. ${ }^{167}$ This method is widely used in Africa and Latin America and has also been resorted to by UNHCR in line with its Statute and subsequent General Assembly resolutions. ${ }^{168}$

More recently, principally in Europe but also in Australia and the United States, ${ }^{169}$ States have managed mass influx situations through the device of "temporary protection", which allows them to extend protection to the groups concerned without initially going into individual status determinations, ${ }^{170}$ when, based on certain indicators, the need for international protection is expected to be of a reasonably short duration. ${ }^{171}$ According to UNCHR, the granting of temporary protection "neither pronounces on nor compromises eligibility under the Convention but, in the interim term, ensures that immediate international protection needs are met", ${ }^{172}$ and it has been acknowledged that individual procedures under the Convention can be kept "on hold". 173

appropriate and cost-effective responses to much smaller groups of people than implied when used in conjunction with the term "mass-influx"'. Albert has also argued group determination does not limit to mass influx situations, see Albert, above n 153.

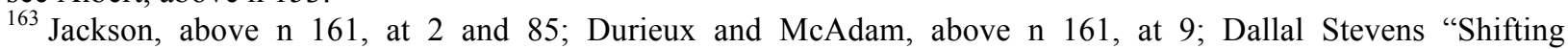
Conceptions of Refugee Identity and Protection: European and Middle Eastern Approaches" in Kneebone, Stevens, and Baldassar (eds) Refugee Protection and the Role of Law: Conflicting Identities (Routledge, Oxon, 2014) 73 at 76.

${ }^{164}$ UNHCR, above n 159, at [17]. See also Jean-François Durieux "The Many Faces of 'Prima Facie': Group-Based Evidence in Refugee Status Determination" (2010) 25(2) Refuge 151 at 153: "a 'highly individualistic' approach [to the Convention Refugee Definition] is misguided and should be questioned as a matter of principle".

${ }^{165}$ UNHCR, above n 159, at [4]; Durieux and McAdam, above n 161, at 11.

${ }^{166}$ Durieux and McAdam, above n 161, at 11.

${ }^{167}$ UNHCR, above n 159 , at [4].

${ }^{168}$ UNHCR, above n 159, at [7].

${ }^{169}$ Sztucki, above n 114, at 65; UNHCR, above n 159, at [4].

${ }^{170}$ UNHCR, above n 159, at [4].

${ }^{171}$ According to UNHCR, "[t]emporary protection is also appropriate for dealing with influxes where the cause of flight is still unclear; where it is objectively apparent that the group largely consists of persons who, under an individualized system, would qualify for complementary protection; or in the context of a harmonized regional approach". UNHCR Ensuring International Protection and Enhancing International Cooperation in Mass Influx Situations: Advance Summary Findings in the Study Commissioned by UNHCR, EC/54/SC/CRP.11 (June 2004), at [6]. But see Australian Department of Immigration and Multicultural Affairs, above n 162; Albert, above n 153.

${ }^{172}$ UNHCR, above n 171, at [6].

${ }^{173}$ UNHCR, above n 159, at [4]. 
As mentioned in chapter I, China's experience with the Indochinese refugees, the North Korean escapees, and the displaced minorities from Myanmar all involve large-scale inflows of displaced persons from neighbouring countries. The situations of all these groups have some of the features of mass influx identified by UNHCR. ${ }^{174}$ Rutinwa has pointed out that prima facie determination was used in Asia during the Indochinese refugee crisis; ${ }^{175}$ refugees fleeing Vietnam were accorded prima facie refugee status until the adoption of the CPA, which requires individual assessment, in 1989. ${ }^{176}$ Indeed, China's recognition of the refugee status of Indochinese refugees appears to be group recognition. ${ }^{177}$ As mentioned in chapter I, there is no evidence that the Indochinese refugees in China were assessed individually before or after China's announcement of its recognition of their refugee status in August 1979. In the situation of the North Korean escapees, while no evidence indicates that individual situations were accessed for the purposes of refugee status determination, China has explicitly denied that they are refugees. ${ }^{178}$ On the contrary, China's response to the displaced Kokangs and the displaced Kachins bears some resemblance to "temporary protection". It hosted the Kokangs without recognising or denying their refugee status; it also hosted the Kachins for more than one year although claiming that they were not refugees. ${ }^{179}$

It is not a secret that many States are remarkably reluctant to recognise displaced persons arriving en masse in their territory as refugees. ${ }^{180}$ UNHCR has acknowledged the "unduly heavy burden" on receiving States in mass influx situations, ${ }^{181}$ and has repeatedly emphasised the need to ensure admission to safety, protection from refoulement, and basic humanitarian treatment

\footnotetext{
${ }^{174}$ They all involve "considerable numbers of people arriving over an international border". The Indochinese refugee influx, the Kokang Incident, and the Kachin influx are also characterised by "a rapid rate of arrival" and "inadequate absorption or response capacity in host States, particular during emergency". In the situation of the North Korean escapees, in the absence of accurate statistics, it is commonly considered as a mass influx situation, although the inflow may have been gradual. In addition, for the purposes of the UNHCR Global Consultation in 2001, mass influx situations referred to both the phase in which States are faced with refugee arrivals on a large scale, and the situation of States "which host a large [refugee] population over many years." UNHCR Global Consultations on International Protection Mechanisms of International Cooperation to Share Responsibilities and Burdens in Mass Influx Situations, EC/GC/01/7 (19 Feburary 2001), at [11].

${ }^{175}$ Rutinwa, above n 153, at 2.

${ }^{176}$ Rutinwa, above $\mathrm{n} 153$, at 2.

${ }^{177}$ Most of the Indochinese refugees received by China arrived between 1978 and 1982. There is no statistics showing new arrivals after 1988. Dayou Xiang "rang shiren liaojie guangxi jiedai anzhi yinzhi nanmin de zhenxiang [Let People around the World Know about the Truth of Guangxi's Receiption and Settlement of Indochinese Refugees]" (2011) 1 Overseas Chinese Journal of Bagui 3 at 3. See also chs I and IV.

${ }^{178}$ See chs I and IV.

${ }^{179}$ See chs I and IV.

${ }^{180}$ For example, Indochinese boat people were referred to as "displaced persons" and "asylum seekers" for many years by the international community as a whole until they were "elevated" to refugee status; despite abundant evidence of ethnically-based persecution of the Bosnians fleeing from Bosnia and Kosovo en masse, European States were reluctant to place the "refugee" label on them. Durieux and McAdam, above n 161, at 7; Sztucki, above n 114, at 65 (with further reference); Khalid Koser and Richard Black "Limits to Harmonization: The 'Temporary Protection' of Refugees in the European Union" (1999) 37 (3) International Migration 521 at 526.

${ }^{181}$ UNHCR Excom Conclusion on Protection of Asylum-Seekers in Situations of Large-Scale Influx, No. 22 (XXXII) - 1981 (21 October 1981), at [IV (1)].
} 
rather than to "provide immediately the full standards of treatment foreseen under the 1951 Convention". 182

Kourula has rightly pointed out that large-scale population movements require striking a balance between the right of States to regulate and manage the admission of aliens to their territories and the adherence to the principles of refugee law. ${ }^{183}$ It remains an issue open for debate, however, as to where the balancing point should be. For example, while the United Nations High Commissioner for Refugees, Ogata, has observed the device of temporary protection as an instrument balancing the protection of the needs of people with the interests of states receiving them, ${ }^{184}$ Lambert and Durieux and McAdam have observed that temporary protection was used in most European States as a way to suspend or by-pass normal asylum procedures. ${ }^{185}$

\section{People Fleeing Armed Conflict and the Situation of Displaced Ethnic Kokangs and Kachins from Myanmar}

To be clear, armed conflict usually causes large-scale cross-border displacement, but not all persons fleeing armed conflict arrive at the country of asylum as part of a large group. Mass influx situations are often caused by armed conflict, but they also occur as a consequence of other events; for example, the mass influx of Indochinese refugees in China and Southeast Asian countries was not a result of armed conflict.

The Convention does not explicitly extend its protection to people fleeing armed conflict. As pointed out by Mr Robinson of Israel during the Conference of Plenipotentiaries in 1951, " $[\mathrm{t}]$ here is no provision ... for refugees fleeing from hostilities unless they were otherwise covered by article 1 of the Convention". ${ }^{186}$

Although there is nothing in the Convention Refugee Definition itself which would exclude its application to persons caught up in armed conflicts, ${ }^{187}$ the circumstance of persons fleeing war continues to challenge the interpretation and application of the Convention Refugee

\footnotetext{
${ }^{182}$ UNHCR, above n 159; UNHCR, above n 161; UNHCR Excom, above n 181; UNHCR, above n 154; UNHCR Excom General Conclusion on International Protection, A/AC.96/839 (11 October 1994).

${ }^{183}$ Kourula, above $\mathrm{n} 105$, at 102.

${ }^{184}$ Sadako Ogata, United Nations High Commissioner for Refugees "Statement at the intergovernmental consultations on asylum, refugee and migration policies in Europe, North America and Australia", Washington DC, May 1997, as cited in Koser and Black, above n 180, at 523.

${ }^{185}$ Lambert, above n 164, at 209: "Hence, a political compromise had to be found; a policy of 'temporary protection' was developed and was implemented in most European states as a way to suspend or by-pass normal asylum procedures"; Durieux and McAdam, above n 161, at 7: "The debate surrounding temporary protection throughout the 1990s was dominated by an urge to avoid 'refugee' terminology, without, however, giving the impression that the application of the Convention was suspended. States were forced to admit that there had to be Convention refugees among the beneficiaries of temporary protection, but they did not want to be bound by legal constraints. The device they used was a temporary suspension of asylum procedures, or at least of asylum decisions, coupled with the discretionary grant of an ad hoc 'interim' status."

${ }^{186}$ Statement of Mr Robinson of Israel, A/CONF.2/SR.22, at 6.

187 UNHCR "Information Note on Article 1 of the 1951 Convention" (1 March 1995) Refworld $<$ http://www.refworld.org/docid/3ae6b32c8.html> (accessed 8 November 2013), at [8]; Goodwin-Gil and McAdam,

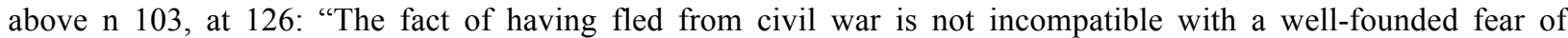
persecution in the sense of the 1951 Convention".
} 
Definition. ${ }^{188}$ For example, the stark variation of refugee recognition rates for Afghan, Somali and Iraqi asylum seekers in different European countries indicates significant divergences in interpretation and application of the Convention Refugee Definition with regard to persons fleeing armed conflicts. ${ }^{189}$ Goodwin-Gill and McAdam have observed that decision-makers too often perceive civil conflicts "as giving rise to the situations of general insecurity that somehow exclude the possibility of persecution" and pointed out that a "closer look of the background of the conflict and the ways in which it is fought will often establish a link to the Convention". 190

The UNHCR Handbook maintains the view that "[p]ersons compelled to leave their country of origin as a result of international or national armed conflicts are not normally considered refugees under the 1951 Convention or 1967 Protocol", emphasising that these persons enjoy protection under international humanitarian law. ${ }^{191}$ However, UNHCR has also noted that: ${ }^{192}$

many of those fleeing today's armed conflicts do come within the refugee definition of the 1951 Convention because these conflicts are rooted in ethnic, religious or political differences which specifically victimize certain groups.

It has been generally accepted by UNHCR, a number of States, and scholars that persons fleeing armed conflict may qualify as refugees under the Convention, although the mere fact of having fled from armed conflict does not per se suffice. ${ }^{193}$ Hathaway and Foster have noted the general acceptance of the principle that, with respect to claims of refugee status by persons fleeing war, "whatever the number of people affected, the relevant issues are the seriousness of the harm that may eventuate, and its causal connection to a protected form of civil or political status". 194

In the seminal Salibian decision, the Canadian Federal Court of Appeal stated: ${ }^{195}$

[a] situation of civil war in a given country is not an obstacle to a claim provided the fear felt is not that felt indiscriminately by all citizens as a consequence of the civil war, but that felt by the

\footnotetext{
${ }^{188}$ Hathaway and Foster, above n 99, at 177; Vanessa Holzer "The 1951 Refugee Convention and the Protection of People Fleeing Armed Conflict and Other Situations of Violence" (September 2012) UNHCR Legal and Protection Policy Series, PPLA/2012/05, <http:/www.refworld.org/docid/50474f062.html> (accessed 8 September 2014).

${ }^{189}$ Holzer, above n 188, at 2; UNHCR, above n 149, at 17.

${ }^{190}$ Goodwin-Gill and McAdam, above n 103, at 126.

${ }^{191}$ UNHCR, above n 104, at [164].

192 UNHCR "Self-Study Module 2: Refugee Status Determination: Identifying who is a refugee" (1 September 2005) UNHCR < http://www.unhcr.org/publ/PUBL/43144dc52.pdf> (accessed 28 April 2014), sec 2.3.4. UNHCR has also expressed the same view in other documents, eg UNHCR Note on International Protection, A/AC.96/850 (1 September 1995), at [11]; UNHCR, above n 100, at [20]-[21].

${ }^{193}$ Holzer, above n 188, at 1 , further reference cited there. However, Holzer also noted discrepancies in State practice: "[i]n some States, it results in a higher standard of proof of persecution for people who have fled armed conflict and other situations of violence, while in others, such situations require a differentiated risk".

${ }^{194}$ Hathaway and Foster, above n 99, at 177.

${ }^{195}$ Vahe Salibian v Canada (Minister for Employment and Immigration) (1990) 3 FC 250, at 258, cited from Hathaway and Foster, above n 99, at 180.
} 
applicant himself, by group with which he is associated, or, even, by all citizens on account of a risk of persecution base on one of the reasons stated in the definition.

Indeed, whereas persons fleeing truly generalised or indiscriminate violence have always had difficulty in establishing a nexus between their fear as a consequence of the armed conflict and any of five grounds provided in the Convention Refugee Definition, ${ }^{196}$ the mere fact of having fled armed conflict does not preclude the finding of a well-founded fear of being persecuted for any of the five Convention grounds. ${ }^{197}$ First, however many people are similarly affected, if a person is at risk of being persecuted for reasons of any of the five Convention grounds, the person should qualify for refugee status under the Convention. ${ }^{198}$ Second, where large groups are seriously affected by a government's policies or by the breakout of uncontrolled communal violence, it appears to be wrong in principle to limit the concept of persecution to measures immediately identifiable as direct and individual. ${ }^{199}$ On the one hand, the Convention Refugee Definition does not require a refugee claimant to show that he or she would be individually targeted. ${ }^{200}$ On the other, as noted by Goodwin-Gill and McAdam, general measures are frequently directed at groups identifiable by reference to the Convention reasons for persecution. $^{201}$

In Würzburg, the German Administrative Court found that Bosnian Muslims fleeing a Serbcontrolled area were not simply victims of generalised war or violence: ${ }^{202}$

[in a context of civil war] persecution is established when the behaviour of the state forces aims at the physical extermination of the ethnic, cultural or religious identity of a part of the population.

The same statement of the German Administrative Court in Würzburg may well apply to the displaced ethnic Kokangs and ethnic Kachins in China, who fled military clashes between the Myanmar government troops and local ethnic military forces. The ethnic dimension of the armed conflict in Kokang Region and Kachin State is clear. Additionally, interviews with displaced Kachins also indicate that there is likely to be a link between the fear and their ethnicity.

\footnotetext{
${ }^{196}$ Eg Hersi v Canada (Minister for Employment and Immigration) (1993) FTR 226; Rizkallah v Canada (Minister for Employment and Immigration) (1992) 156 NR 1.

197 Holzer, above $\mathrm{n} 188$, at 2.

${ }^{198}$ Hathaway and Foster, above n 99, at 176: "if the harm is both sufficiently serious and impacts persons by reason of their civil or political status, then a claim to Convention refugee status is made out, however many people are similarly affected."

${ }^{199}$ Goodwin-Gill and McAdam, above n 103, at 129; Atle Grahl-Madsen The Status of Refugees in International Law (Sijthoff, Leyden, 1966), vol 1, at 213.

${ }^{200}$ Holzer, above n 188 , at 16.

${ }^{201}$ Goodwin-Gill and McAdam, above n 103, at 129.

${ }^{202}$ W 9 K 92.30416 446.11 Ger VG Würzburg [German Administrative Court, Würzburg], 5 March 1994, unofficial translation, emphasis added, cited from Hathaway and Foster, above n 99, at 178.
} 
Whilst in most cases refugees leave their home country because of a fear of being persecuted, ${ }^{203}$ it is well-recognised that the Convention does not require the fear of being persecuted to arise before refugees leave their home country. ${ }^{204}$ The Convention Refugee Definition simply requires that a refugee " $i s$ outside the country of his nationality"; ${ }^{205}$ the present tense ensures that persons in need of protection sur place are protected by the Convention on an equal footing with those who flee after the risk of persecution is apparent. ${ }^{206}$ A person who was not a refugee when he or she left their country, but who becomes a refugee at a later date, is called a refugee sur place. ${ }^{207}$

The classic sur place refugee claim derives from a significant change of circumstances in the country of origin at a time when the claimant is abroad for reasons wholly unrelated to a need for protection. ${ }^{208}$ For example, students, migrant workers, and diplomats who initially intended to go home after their study or work placement abroad may later find they cannot return home because of a Convention reason. Sur place claims deriving from events occurring after the claimant's departure from the country of origin are usually looked upon favourably. ${ }^{209}$

A sur place refugee claim can also arise as a result of the person's activities outside her country of origin. ${ }^{210}$ For example, participation in political activism abroad against the government of the home country, association with recognised refugees, or conversion to another religion intolerable in the home country may lead to such sur place claims. ${ }^{211}$ Sur place claims deriving from the claimant's own activities outside the country of origin are often suspected as manipulated. ${ }^{212}$

As Hathaway and Foster and Zimmermann and Mahlet noted, unauthorised departure from the home country may form the basis of a refugee status claim sur place. ${ }^{213}$ According to Hathaway and Foster, if the sanction for illicit travel abroad is severe enough to effectively undermine the fundamental human right to leave and to return to one's country enshrined in art 12 of the International Covenant on Civil and Political Rights (ICCPR) and the country of origin treats

\footnotetext{
${ }^{203}$ Hathaway and Foster, above n 99, at 75; Zimmermann and Mahlet, above n 105, at 324.

${ }^{204}$ See eg UNHCR, above n 104, at [94]; Hathaway and Foster, above n 99, at 75; $S$ v. Chief Executive of the Department of Labour [2007] NZCA 182.

${ }^{205}$ Article 1 A (2), emphasis added.

${ }^{206}$ Hathaway and Foster, above n 99, at 75.

${ }^{207}$ UNHCR, above n 104, at [94].

${ }^{208}$ Hathaway and Foster, above n 99, at 76; Zimmermann and Mahlet, above n 105, at 325.

${ }^{209}$ Sylvie Da Lomba "The EU Qualification Directive and Refugees Sur Place" in Flora A N J Goudappel and Helena S Raulus (eds) The Future of Asylum in the European Union - Problems, Proposals and Human Rights (T M C Asser Press, The Hague, 2011) 43, at 45; Zimmermann and Mahlet, above n 105, at 329.

${ }^{210}$ Hathaway and Foster, above n 99, at 77; Zimmermann and Mahlet, above n 105, at 325; Lomba, above n 209, at 46.

${ }^{211}$ UNHCR, above n 104, at [96]; Hathaway and Foster, above n 99, at 77; Zimmermann and Mahlet, above n 105, at 330 .

${ }^{212}$ Hathaway and Foster, above n 99, at 78; Lomba, above n 209, at 45; Zimmermann and Mahlet, above n 105, at 331. For example, the EU Directive divides persons in need of international protection sur place into two categories, ie those whose fear of persecution or serious harm is based on events occurring after the their departure from their country of origin (art 5.1) and those whose fear of persecution or serious harm is based on post-departure activities they engaged in (art 5.2); it also stipulates that "without prejudice to the Geneva Convention", Member States may determine that an applicant "shall normally not be granted refugee status, if the risk of persecution is based on circumstances which the applicant has created by his own decision since leaving the country of origin" (art 5.3).

${ }^{213}$ Hathaway and Foster, above n 99, at 77; Zimmermann and Mahlet, above n 105, at 330.
} 
unauthorised departure as an implied political opinion of disloyalty or defiance, the criteria of the refugee definition are met. ${ }^{214}$ This scenario is relevant to the discussion on the status of the North Korean escapees in China under international law.

As mentioned in chapter I, China has generally claimed that North Koreans escapees entering China are economic migrants, not refugees. Since assessment of the individual situations of North Korean escapees in China is impractical under China's current policy, ${ }^{215}$ in the limited existing academic scholarship on the status of the North Korean escapees in China under international law, the majority of the authors have argued that the North Korean escapees who flee to China, regardless of their motivations for departing North Korea, should qualify as refugees sur place on the basis that North Koreans leaving North Korea without authorisation would be regarded as betrayers of the regime and would face severe punishment in North Korea. $^{216}$

In light of Hathaway and Foster's theory above, the key test of whether North Korean escapees qualify as refugees sur place lies in whether the punishment for unauthorised border crossing in North Korea amounts to persecution and whether North Korea treats unauthorised border crossing as implied political opinion of disloyalty. It is well known that North Korea strictly limits international travel of its citizens to such an extent that, according to the UN Human Rights Council, the travel restriction practically amounts to a total travel ban for ordinary North Koreans. ${ }^{217}$ Such restriction on international travel is enforced through "extreme violence and harsh punishment". ${ }^{218}$ It is generally recognised that unauthorised departure from North Korea is now regularly considered by North Korean authorities as treason, ${ }^{219}$ a crime punishable by a minimum of five year "reform through labour" under art 62 of the North Korean Criminal Code, or an offence of "anti-state or anti-people crimes". ${ }^{220}$ Although it has been noted that not all North Korean escapees have been imprisoned or severely punished and the severity of punishments for unauthorised departure has varied considerably over time, ${ }^{221}$ given the large numbers of cases of reported torture of North Korean escapees and the arbitrary nature of the

\footnotetext{
${ }^{214}$ Hathaway and Foster, above $\mathrm{n} 99$, at 77.

${ }^{215}$ Empirical research has been conducted with small numbers of North Korean escapees in China. Empirical evidence shows that North Korean escapees left North Korea for a variety of reasons, including economic, political, religious, and other reasons. Hoggard and Noland, above n 59, at 29, further references cited there.

${ }^{216}$ Eg Chan and Schloenhardt, above n 61, at 228; Cohen, above n 61. For different arguments and opinions, see eg Chan and Schloenhardt, above n 61, at 226-228; Eric Yong-Joogn Lee "National and International Legal Concerns regarding Recent North Korean Escapee" (2001) 13 International Journal of Refugee Law 142; Hazel Smith "North Koreans in China: Sorting Fact from Fiction" in Tsuneo Akaha and Anna Vassilieva (ed) Crossing National Borders: Human Migration Issues in Northeast Asia (United Nations University Press, Tokyo, 2005) 165.

${ }^{217}$ UN Human Rights Council Report of the Detailed Findings of the Commission of Inquiry on Human Rights in the Democratic People's Republic of Korea, A/HRC/25/CRP.1 (2014), at [380].

${ }^{218}$ UN Human Rights Council, above n 217, at [380].

${ }^{219}$ UN Human Rights Council, above n 217, at [383]; Piao and Li, above n 81; HRW, above n 59, at 2.

${ }^{220}$ UN Human Rights Council, above n 217, at [383], [406], [1110].

${ }^{221}$ Andrew Wolman "North Korean Asylum Seekers and Dual Nationality" (2013) 24(4) International Journal of Refugee Law 793, at 793, with further references cited there. Lee has also noted that until mid-1996, most North Koreans illegally crossed into China were detained for a short period of time, Lee, above n 216, at 143, with further references cited there.
} 
punishment (without trial), ${ }^{222}$ it is reasonable to conclude that North Koreans who have left North Korea without authorisation and are unwilling to return to North Korea can claim to have a well-founded fear of persecution for the reason of (real or imputed) political opinion. ${ }^{223}$

An implication of this conclusion is that almost every person of North Korea's 25 million population would be able to claim refugee status sur place in China as long as they manage to leave North Korea unless they are otherwise excluded by the Convention, since North Korea does not even issue passports to its citizens except a small number of elite persons. ${ }^{224} \mathrm{Few}$ countries today would find it attractive to guarantee refugee status to 24 million people from a neighbouring country; China is no exception.

Furthermore, the legal discussion on the legal status of the North Korean escapees under international refugee law also involves the issue of dual nationality, which could render the argument of refugee sur place irrelevant. ${ }^{225}$

\section{$5 \quad$ Dual Nationality and the Situation of North Korean Escapees}

Article 1A(2) of the Convention stipulates that:

[i]n the case of a person who has more than one nationality, the term "the country of his nationality" shall mean each of the countries of which he is a national, and a person shall not be deemed to be lacking the protection of the country of his nationality if, without any valid reason based on wellfounded fear, he has not availed himself of the protection of one of the countries of which he is a national.

It is clear from this provision that a person with dual or multiple nationality would be considered as a refugee only if she is either unable or legitimately unwilling to avail herself of the protection of the government of any of her nationalities. Because of the surrogate nature of the protection afforded by refugee law, it is an underlying assumption of refugee law that, wherever available, national protection takes precedence over international protection for the displaced person concerned. $^{226}$

In examining whether a person has dual or multiple nationality, it is necessary to distinguish between the possession of a nationality in the legal sense and the availability of protection by the

\footnotetext{
${ }^{222}$ See generally UN Human Rights Council, above n 217.

${ }^{223}$ However, Chan and Schloenhardt have rightly noted that it may be necessary to re-examine the case for refugees sur place if reforms in North Korea has led to a reduction in the penalties. Chan and Schloenhardt, above n 61, at 229 in footnote 77, refering to Vitit Muntarbhorn Report of the Special Rapporteur on the Situation of Human Rights in the Democratic People's Republic of Korea", E/CN.4/2005/34 (2005) and UN Human Rights Committee Concluding Observations and Recommendations of the Human Rights Committee: Democratic People's Republic of Korea, CCPR/ CO/72/PRC (2001). Muntarbhorn noted that information received in late 2004 indicates that revision of the DPRK Criminal Code has led to a reduction in the penalties for leaving a country for non-political reasons to a pardon such as, leaving for greater employment opportunities in neighbouring countries (page 38). The UN Human Rights Committee noted of "the reduction of the number of carrying the death penalty from 33 to 5" (para 4).

${ }^{224}$ In 2013 , the estimated population of North Korea was 24.9 million.

225 See further below.

${ }^{226}$ Hathaway and Foster, above n 99, at 56; UNHCR, above n 104, at [106].
} 
country concerned. ${ }^{227}$ A nationality may be deemed ineffective if it does not entail the protection normally granted to nationals. ${ }^{228}$ For example, in Tji, the Australian Federal Court held that if the putative state of citizenship "does not accept that [its nationality] law apply in the way [assumed]", the nationality is ineffective. ${ }^{229}$ The UNHCR Handbook further states that: ${ }^{230}$

As a rule, there should have been a request for, and a refusal of, protection before it can be established that a given nationality is ineffective. If there is no explicit refusal of protection, absence of a reply within reasonable time may be considered a refusal.

Hathaway and Foster have noted that concerns of ineffectiveness would arise where the benefits of nationality, while theoretically available, cannot in practice be accessed by the person concerned, for example, when the person is "unable to travel to or enter the territory where the rights associated with nationality are in principle available". 231

In the case of North Korean escapees, it is commonly understood that under South Korean law, North Koreans are South Korean citizens from birth unless their parents were both non-Koreans (that is either North Korean or South Korean). ${ }^{232}$ According to art 3 of the South Korean Constitution, "[t]he territory of the Republic of Korea shall consist of the Korean peninsula and its adjacent islands". ${ }^{233}$ Under art 2 of the Korean Nationality Act, any person falling in one of the following categories "shall be a national of the Republic of Korea at birth": (1) a person whose father or mother is a national of the Republic of Korea at the time of a person's birth; (2) a person whose father was a national of the Republic of Korea at the time of the father's death, if the person's father died before the person's birth; (3) a person who was born in the Republic of Korea, if both of the person's parents are unknown or have no nationality. ${ }^{234}$

Since North Koreans (except those born to two foreign parents) are South Korean nationals from birth under South Korean law, ${ }^{235}$ the issue at stake is the effectiveness of the South Korean nationality, not the possibility of acquisition of South Korean nationality. It is self-evident that for North Koreans in North Korea, the South Korean nationality is ineffective. The North Koreans whose South Korean nationality is in question here are North Korean escapees who were born to at least one Korean parent.

\footnotetext{
${ }^{227}$ UNHCR, above n 104, at [107].

${ }^{228}$ UNHCR, above n 104, at [107].

${ }^{229}$ Lay Kon Tji v. Minister for Immigration \& Ethnic Affairs [1998] FCA1380, at 696.

${ }^{230}$ UNHCR, above $\mathrm{n} 104$, at [107].

${ }^{231}$ Hathaway and Foster, above n 99, at 57.

${ }^{232}$ Wolman, above n 221, at 798; Lee, above n 216, at 146; KK and ors (Nationality: North Korea) Korea CG [2011] UT 92 (IAC), at [49]; GP and others (South Korean citizenship) North Korea CG [2014] UT 00391 (IAC).

${ }^{233}$ Wolman, above n 221, at 798; Lee, above n 216, at 146; Chan and Schloenhardt, above n 61, at 233.

${ }^{234}$ Wolman, above $\mathrm{n} 221$, at 798 .

${ }^{235}$ North Koreans who were born to two foreign parents are not regarded as South Korean citizens by South Korean Law. They, if not having effective nationality of another country, should qualify for refugee status sur place if they leave North Korea without authorisation regardless of their motivation for leaving.
} 
To examine whether their South Korean nationality, as provided by South Korean law, is effective, the following questions need to be answered. Does South Korea accept that its nationality law applies in the way it is commonly understood? Does South Korea offer protection to North Korean escapees as its citizens? If the answers to these questions are yes, is the protection offered by South Korea available to North Korean escapees?

In the Young Soon Lee case in 1996, the Supreme Court of South Korea confirmed that a plaintiff, a North Korean national with a Chinese Foreign Resident Card, is a South Korean citizen. ${ }^{236}$ Hwang, who is a leading human rights lawyer and the principal drafter of the 2013 South Korean Refugee Act which incorporated the Convention into South Korean law, conformed in his expert report to the United Kingdom Upper Tribunal that South Korea did not consider its Refugee Act applicable to North Koreans, who are considered not as aliens but as citizens of South Korea. ${ }^{237}$ It appears that the common understanding of South Korean nationality law is in harmony with South Korea's interpretation of its own nationality law.

It is well recognised that South Korea usually does endeavour to provide protection to North Korean escapees and to assist them to travel to South Korea. ${ }^{238}$ Lee noted in 2001 that "in practice, South Korea's overseas missions used to accept North Korean escapees and issue passports or necessary travel documents if they seek asylum or temporary refuge there". ${ }^{239}$ In 1997, South Korea passed the Protection of North Korean Residents and Support of Their Settlement Act (the Protection Act), ${ }^{240}$ which is designed to provide protection and support to North Koreans defecting from North Korea (art 1). Article 7 of the Protection Act provides that:

1. Any person who has defected from North Korea and desires to be protected under this Act shall apply for protection to the head of an overseas diplomatic or consular mission ....

2. The head of an overseas diplomatic or consular mission...who receives such an application for protection...shall without delay inform the fact to the Minister of National Unification and the Director of the Agency for National Security Planning.

3. The Director of the Agency for National Security Planning notified pursuant to the provision of Paragraph 2 shall take provisional protective measures or other necessary steps and shall without delay inform the Minister of National Unification of the result.

\footnotetext{
${ }^{236}$ Young Soon Lee SC $96 \mathrm{Nu}$ 1221, 12 November 1996, cited from Vitit Muntarbhorn Report of the Special Rapporteur on the Situation of Human Rights in the Democratic People's Republic of Korea, E/CN.4/2006/35 (23 January 2006), at [61]; Jeewon Min "Surrogate Protection in Canada and Potential Nationality in South Korea: Does a North Korean Asylum-Seeker Have a 'Genuine Link' to South Korea?" (2013) CARFMS $<$ http://carfms.org/sites/default/files/North\%20Korean\%20Refugee\%20Status\%20In\%20Canada\%202013\%20Essa y\%20Contest $\% 20$ CARFMS\%20web.pdf > (accessed 12 February 2014), at 11.

${ }^{237} \mathrm{GP}$, above $\mathrm{n} 232$, at [96].

${ }^{238}$ Eg Muntarbhorn, above $\mathrm{n}$ 236, at [62]; Seymour, above n 89, at 25; HRW, above $\mathrm{n} 59$, at 30; KK, above $\mathrm{n} 232$; $G P$, above n 232.

${ }^{239}$ Lee, above n 216, at 148, referring to A Directory of the ROK Ministry of Foreign Affairs (Seoul, 3 April 1983), emphasis added.

240 Law number 6474, Partial revision on 24 May 2001, available at Reworld $<$ http://www.refworld.org/docid/3ae6b4ef28.html> (accessed 18 October 2014).
} 
The 2005 White Paper on Korean Unification issued by Ministry of Unification also stated that: ${ }^{241}$

In the case of North Korean refugees residing in a third country who file an application for protection, the South Korean Government will provide temporary protection through its consulate in the third country and assist them in entering South Korea. Upon entry into South Korea, the Government will decide on his/her protection based on the results of a joint investigation by relevant government agencies.

However, the Protection Act specifically excludes certain categories of North Korean escapees from its protection under art $9,{ }^{242}$ and North Korean escapees falling within the scope of this article have reportedly been denied the right of entry to South Korea. ${ }^{243}$ As Wolman has noted, if a North Korean asylum seeker is "covered by one of the article 9 exceptions of the Protection Act, the right of entry to South Korea would be questionable at best, and nationality should be presumed ineffective". 244

Additionally, where South Korean foreign missions explicitly refuse, or do not respond within reasonable time, to assist North Korean escapees to entry South Korea, the protection associated with the putative South Korean nationality of the North Koreans concerned can be deemed ineffective. A mid-level official at the South Korean Ministry of Unification admitted that in 1997 the basic policy of accepting all North Koreans who wished to migrate to the South was instituted and communicated to embassies and consulates. ${ }^{245}$ However, he explained that South Korean diplomatic missions had a discretion in considering relations with the host country: ${ }^{246}$

\footnotetext{
${ }^{241}$ Republic of Korea Ministry of Unification "Peace and Prosperity: White Paper on Korean Unification" (2005), cited from Muntarbhorn, above n 236, at [62].

${ }^{242}$ Such people include: "1. International criminal offenders involved in aircraft hijacking, drug trafficking, terrorism or genocide, etc; 2 . Offenders of non-political, serious crimes such as murder, etc; 3 . Suspects of disguised escape; 4. Persons who have for a considerable period earned their living in their respective countries of sojourn; and 5. Such other persons as prescribed by the Presidential Decree as unfit for the designation as persons subject to protection."

${ }^{243} K K$, above $\mathrm{n} 232$, at [55].

${ }^{244}$ Wolman, above $\mathrm{n} 221$, at 811 . South Korea has not be entirely consistent and clear when applying art 9 of the Protection Act. It seems that South Korea has also provided protection to persons falling within the scope of art 9. See $G P$, above n 232, at [43], referring to Dr Pillkyu Hwang's expert evidence. See also KK, above, $\mathrm{n}$ the 232, Tribunal noted that "[a]rticle 9 of the 1997 Act is not a criterion for decision on citizenship: it is a criterion going only to special protection", at [50], and quoted In, a South Korean lawyer, "diplomatic officers are controlling the number of the entry of North Koreans into South Korea, ... because of the increasing number of application for entry into South Korea by North Koreans since 2005 and the shortage of the temporary facility in housing support for them. Therefore, a person who is expected to be refused protection will be refused of even entering into the country. In that sense, in UK and Canada embassies, the consuls might have taken a position that as person refused protection was not a candidate for South Korean citizenship. In strict legal perspective, it is a wrong interpretation which is against the Protection Act, the Nationality Act, and the Constitution", at [55].

${ }^{245} \mathrm{HRW}$, above $\mathrm{n} 59$, at 31 .

${ }^{246} \mathrm{HRW}$, above n 59, at 31 .
} 
If cooperation between the embassy and the host country is smooth, then it is easy. If the country severely opposes our facilitating resettlement in South Korea, then the embassy won't accept them. If the country protests severely, we won't accept them.

This policy is best exemplified by the practice of the South Korean embassy and consulates in China. As mentioned in chapter I, China generally insists in repatriating North Korean escapees to North Korea. After a series of high profile incidents of North Koreans seeking asylum in foreign embassies and consulates in China, the Chinese authorities have tightened security around foreign embassies and consulates, including the South Korean embassy and consulates, to prevent North Korean escapees from entering those premises. ${ }^{247}$ Although the South Korean government has avidly advocated against China's repatriation of North Korean, once threatening to bring the issue to the UN Human Rights Commission, ${ }^{248}$ it is well known that, in practice, South Korean diplomatic officers are reluctant to deal with North Korean escapees seeking assistance at the South Korean embassy or consulates in China. ${ }^{249}$

Since North Korean escapees in China generally do not have access to the protection associated with the South Korean nationality, the South Korean nationality of North Korean escapees in China is ineffective in the current situation and they should qualify for refugee status unless otherwise excluded in accordance with the Convention. However it should be noted that if China no longer restricts North Korean escapees from approaching the South Korean embassy and consulates in China, unless South Korea changes its current nationality law or policy toward North Korean escapees, North Korea escapees in China who do not fall within art 9 of the Protection Act are likely to have access to the protection of South Korea as South Korean nationals. In that case, they should no longer qualify for refugee status. In August 2014, China released 11 North Korean escapees, who were arrested by Chinese police on the Chinese-Lao border in the same month, to South Korea. ${ }^{250}$ It was the first time China allowed North Korean escapees to go to South Korea directly from China. ${ }^{251}$

It should be pointed out that the approach of the Chinese government and the South Korean government demonstrated that, as observed by Deng, ${ }^{252}$ the issue of North Korean escapees is

\footnotetext{
${ }^{247}$ See ch IV.

${ }^{248}$ Daming Li et al "zhonghan yin 'tuobeizhe' gekong duizhi [Tension between China and South Korea due to 'North Korean Escapees']” (23 February 2012) Xinhua <http://news.xinhuanet.com/world/201202/23/c_122744929.htm> (accessed 20 June 2012).

${ }^{249}$ Wolman, above n 221, at 801; Andrei Lankov "North Korean Refugees in Northeast China" (2004) 44 Asian Survey 856 at 863 .

250 Mark Stone "N Korean Defectors Held On Laos Border" (15 August 2014) Sky News $<\mathrm{http}$ //news.sky.com/story/1317909/n-korean-defectors-held-on-laos-border> (accessed 20 August 2014).

${ }^{251}$ North Korean escapees arrested by Chinese authorities are normally repatriated to North Korea. In a few cases, China previously allowed North Korean escapees who successfully sought asylum in foreign embassies to go to South Korea via a third country.

${ }^{252}$ Yiwen Deng "shifang tuobeizhe bingfei Beijing gaibian lichang [Releasing North Korean Escapees Does not Mean Beijing Has Changed its Position" Financial Times Chinese Edition (online ed, 18 August 2014), available at $<$ http://www.ftchinese.com/story/001057773?full=y $>$ (accessed 20 October 2014).
} 
more of a political one than of a legal one. Any attempts of creating a viable solution for the North Korean escapee crisis in China should take this into consideration.

\section{China's Accession to the Convention and Protocol}

When the Convention and Protocol was drafted, the People's Republic of China, which was established in October 1949, was excluded from the UN. The state of China was represented by the Taiwan-based Republic of China until 1971.

China began to consider joining the Refugee Convention and Protocol in 1979 during the Indochinese refugee crisis. On 1 September 1979, then Minister of Foreign Affairs, Mr Hua Huang, agreed to "consider carefully" the invitation to join the Convention and Protocol in his reply to UNHCR. ${ }^{253}$ On 24 September 1982, China acceded to both instruments, being one of the first Asian State parties to these key legal instruments on refugee protection. ${ }^{254}$ It was also one of the first communist countries to accede to the Convention and Protocol. ${ }^{255}$ China remains one of the few East and Southeast Asian State parties to the Convention and Protocol today.

Upon its accession to the Convention and Protocol, China made reservations on the latter half of art 14 of the Convention, which concerns artistic rights and industrial property, art 16 (3) of the Convention, which concerns access to courts, and art 4 of the Protocol, which concerns settlement of disputes. The Convention and Protocol were extended to Macau upon its handover in 1999 from Portugal to China, but not to Hong Kong which was returned by the United Kingdom to China in 1997.

It is worth noting that though the Indochinese refugee crisis undoubtedly played a crucial role in China's accession to the Convention and Protocol, ${ }^{256}$ China's accession was probably also driven by Beijing's desire to obtain international approval. Following China's opening up and a revival of interest in law in the late 1970s, China ratified a series of international human rights instruments as well as a significant number of other international legal instruments in the early 1980s. Of the 27 human rights instruments to which China was a party as of 2012, eight were ratified between 1981 and $1984 .^{257}$ It is perhaps hard to tell what understanding China had of the Convention Refugee Definition and its obligations under the Refugee Convention and Protocol and whether it had a clear idea of its capacity and willingness to commit to the Convention and Protocol after accession. It was, however, most likely that the Chinese leadership at that time did

\footnotetext{
${ }^{253}$ State Council Public Announcement 1982 NO14 Proposal on Reviewing, Discussing the Decision to accede to the Convention relating to the Status of Refugees and the Protocol relating to the Status of Refugee (10 June 1982).

${ }^{254}$ Japan acceded to the Convention and Protocol in 1981 and 1982 respectively. The Philippines acceded to both instruments in 1981. Turkey and Yemen were also parties to the Refugee Convention and Protocol prior to China's accession. UNHCR Bureau for Asia and the Pacific "Regional Update" (March 2014) UNHCR $<$ http://www.unhcr.org/5000139a9.pdf> (accessed 23 April 2014), at 5.

${ }^{255}$ Sztucki, above n 114, at 55 .

${ }^{256} \mathrm{See}$ ch IV.

${ }^{257}$ SCIO "2012 zhongguo renquan shiye de jinzhan [2012 Progress of Human Rights in China]" (14 May 2012) Xinhua <http://news.xinhuanet.com/politics/2013-05/14/c_115758619.htm> (accessed 28 April 2014); China Human Rights Studies Association "zhongguo jiaru le naxie guoji renquan gongyue he yidingshu [Which International Human Rights Treaties and Protocols Has China Ratified]" (27 March 2006) People Web $<$ http://theory.people.com.cn/GB/49150/49152/4239175.html> (accessed 28 April 2014). China has ratified most of the major human right treaties.
} 
not foresee that China, a Third World communist country producing rather than receiving refugees for decades, would become an increasingly popular destination for refugees, in just 20 years' time. The domestic implementation of the Convention and Protocol will be discussed in part III A of chapter III.

\section{Refugees for the Purposes of the United Nations \\ A United Nations High Commissioner for Refugees}

The Office of UNHCR was established in 1950, one year prior to the adoption of the Convention. The historical background of the establishment of UNHCR is that the major western powers, especially the United States, were looking for an international refugee agency that would not present a threat to their sovereignty or add new financial obligations. ${ }^{258}$ Therefore, the office of UNHCR was created as a small temporary organisation with narrow authority and an initial life span of three years. According to the UNHCR Statute, UNHCR acts under the authority of the General Assembly of the UN (para 1) and follows policy directives given by the General Assemble or the Economic and Social Council (para 3).

Its core responsibilities, as stated in the Statute, are to provide legal protection for refugees under the auspices of the UN and to find durable solutions to the refugee problem through voluntary repatriation or assimilation in new national communities (para 1). It is to engage in additional activities as the General Assembly may determine (para 9). The UNHCR Statute also states that the work of UNHCR should be "entirely non-political" (para 2).

Created as a modest institution with little independence and limited functions, UNHCR "has had little power other than moral authority and persuasion" to achieve its mandate. ${ }^{259}$ Through its involvement in refugee matters, UNHCR established itself as an impartial humanitarian organisation with unique expertise and experience on refugee law and forced migration. ${ }^{260}$ States relied on UNHCR for advice, information and assistance, which, in time, improved UNHCR's negotiation power with States. Gradually, UNHCR grew into the world's leading international refugee organisation with considerable independence and moral authority. Headquartered in Geneva, it now has field and regional offices in 126 countries, providing assistance to nearly 34 million people. ${ }^{261}$ In 2003, its mandate was extended by the UN General Assembly "until the refugee problem is solved". ${ }^{262}$

A challenge for UNHCR is that despite the "non-political" nature of its work, it operates in a political environment. Since UNHCR receives only a modest budget from the UN to support its administration work, it has to raise the funds from donor States to finance its operations. This

\footnotetext{
${ }^{258}$ Alexander Betts et al UNHCR: The Politics and Practice of Refugee Protection (3rd ed, Routledge, London, 2012), at 15 .

${ }^{259}$ At 4.

${ }^{260}$ At 20 .

${ }^{261}$ UNHCR The State of the World's Refugees 2012: In Search of Solidarity (Oxford University Press, Oxford, 2012), at 2. Statistics are as of November 2011.

${ }^{262}$ UNHCR "How UNHCR is Run and Structured" UNHCR < http://www.unhcr.org/pages/49c3646c80.html> (accessed 28 April 2014).
} 
funding mechanism renders UNHCR dependent on voluntary donations from States and arguably enables donor States to exercise influence on the work of UNHCR. For example, States can "bookmark" their donations, ie designating their donations to particular groups or regions of their choice rather than making general or unconditional donations. UNHCR has constantly faced the question of "whether and how to adapt its own work and mandate to better serve the interest of States" in its history, ${ }^{263}$ and will continue to face the same question.

\section{B Refugees for the Purposes of the United Nations and Expansion of UNHCR Mandates}

The UNHCR Statute, which was adopted in 1950, defines a refugee in a way that is very similar to the Convention. The Statute first provides that the competence of UNHCR extends to any person who is considered a refugee under a number of earlier arrangements (para 6A(i)) and who, as a result of events occurring before 1 January 1951, is outside her country of origin and is unable or unwilling to avail herself of the protection of that country, owing to well-founded fear of being persecuted for reasons of race, religion, nationality or political opinion or for reasons other than personal convenience (para 6A(ii)). The Statute further includes in UNHCR's competence: ${ }^{264}$

[a]ny other person who is outside the country of his nationality, or if he has no nationality, the country of his former habitual residence, because he has or had well-founded fear of persecution by reason of his race, religion, nationality or political opinion and is unable or, because of such fear, is unwilling to avail himself of the protection of the government of the country of his nationality, or, if he has no nationality, to return to the country of his former habitual residence.

The UNHCR Statute's definition of a refugee is hence without geographic or temporal limitation. Since 1957, UNHCR has been authorised to assist displaced persons who do not fall within the refugee definition provided by the Statute. ${ }^{265}$ As a result of various resolutions of the UN General Assembly and the Economic and Social Council (ECOSOC), ${ }^{266}$ UNHCR is mandated to assist a range of persons "of concern", including not only refugees but also other groups of people in need of protection or assistance. ${ }^{267}$ Gradually, UNHCR's definition of refugee was also broadened. A refugee under UNHCR's mandate is defined as: ${ }^{268}$

\footnotetext{
${ }^{263}$ Betts et al, above n 258, at 5 .

${ }^{264}$ Para 6B.

${ }^{265}$ Goodwin-Gill and McAdam, above n 103, at 24.

${ }^{266}$ See Betts et al, above n 258, ch 2, 3 and 4; Goodwin-Gill and McAdam, above n 103, ch 2.3.2.

${ }^{267}$ Besides refugees, "people of concern" to UNHCR include asylum seekers, stateless persons, returned refugees, internally displaced persons (IDPs) and returned IDPs and any other individuals who do not necessarily fall directly into any of the other groups but to whom UNHCR may extend it protection and/or assistance service. UNHCR, above $\mathrm{n} 261$, at 2 .

${ }^{268}$ UNHCR "Self-Study Module 1: An Introduction to International Protection. Protecting Persons of Concern to UNHCR" (1 August 2005) UNHCR <http://www.unhcr.org/publ/PUBL/3ae6bd5a0.pdf> (accessed 28 April 2014), section 3.1.4.
} 
any person who falls within the refugee definition as contained in Article 1A(2) of the 1951 Convention or who is outside his/her country of origin or habitual residence and is unable to return there because of serious and indiscriminate threats to life, physical integrity or freedom resulting from generalized violence or events seriously disturbing public order.

UNHCR's involvement in national refugee status decision-making processes is grounded in its supervisory role and State parties' commitment to cooperate with UNHCR under the Convention and Protocol. Both the Convention and Protocol provide for cooperation between States and UNHCR, which extends to RSD according to arrangements made in various States. ${ }^{269}$ Participation in national RSD process allows UNHCR to monitor closely matters related to refugee status and of the entry and removal of asylum seekers. ${ }^{270}$ UNHCR also provides regular guidance on issues of interpretation. At the request of States members of the UNHCR Executive Committee, UNHCR issued the Handbook on Procedures and Criteria for Determining Refugee Status (UNHCR RSD Handbook) in 1979, which is relied on by States as an authoritative source of interpretation of the Convention Refugee Definition.

Many State parties have established their own national RSD criteria in accordance with the Convention. Though UN General Assembly resolutions can extend UNHCR's mandate, it is commonly acknowledged that they do not directly impose obligations on States to expand their refugee protection. ${ }^{271}$ The gap between a "mandate refugee" and a "Convention refugee" therefore may raise questions when UNHCR and States have different opinions. ${ }^{272}$

As mentioned above, UNHCR does not have the power to force its opinion on a State, but a State ought to give due consideration in good faith to UNHCR's opinion.

\section{China and UNHCR}

China is a member of UNHCR's governing body, the Executive Committee of the High Commissioner's Programme (Excom). Cooperation between UNHCR and China dates back to the early 1950s when a UNHCR Special Office operated in Shanghai to evacuate the European refugees between 1952 and $1956 .{ }^{273}$ UNHCR returned to China almost a quarter century later in February 1980 when UNHCR established a task office in Beijing to respond to the Indochinese refugee influx. ${ }^{274}$

In a broader sense, interactions between UNHCR and China never really stopped between 1956 and 1980, although they often happened in an indirect way. For example, in 1958, the state of

\footnotetext{
${ }^{269}$ UNHCR, above n 104, Preamble.

${ }^{270}$ Goodwin-Gill and McAdam, above n 103, at 532.

${ }^{271}$ Goodwin-Gill and McAdam, above n 103, at 428.

${ }^{272}$ Goodwin-Gill and McAdam have argued that a number of factors in the existing mechanism "ought in principle to reduce" the likelihood of disagreement. On the one hand, State parties have the obligation under the Convention and Protocol to facilitate UNHCR in exercise of its duty of supervising the application of international conventions for refugee protection; on the other hand, UNHCR's direct or indirect participation in national RSD procedures of State parties enhances the harmonisation of decisions. Problems of different positions are more likely to happen where States decline to conduct RSD. Goodwin-Gill and McAdam, above n 103, at 52.

${ }^{273}$ Peterson, above n 17 , at 331.

${ }^{274}$ UNHCR, above n 41.
} 
China, then represented at the UN by Taiwan, became a member of UNHCR Excom. ${ }^{275}$ It was the first country in the East and Southeast Asian region to become a member of the Excom. When the representation of the state of China at the UN transferred from Taiwan to the People's Republic of China in 1971, UNHCR ExCom terminated the membership of the former in 1972. Prince Sadruddin Aga Khan, then UN High Commissioner for Refugees, noted in February 1972 that the entry of the People's Republic of China to the UN: ${ }^{276}$

is important not only in the political field but also to UNHCR specifically because China is a member of our Executive Committee. ... When the People's Republic became a member, it automatically had the right to avail itself of their seat on our governing body.

The People's Republic of China started to participate in activities at UNHCR Excom in $1979 .{ }^{277}$ In the same year, it requested UNHCR to propose an aid programme at the UN General Assembly Meeting to assist the Indochinese refugees in China. The aid programme was approved by the UN GA and became one of the very first UN aid programmes in China. ${ }^{278}$

In 1980, a UNHCR Task Office was established in Beijing to assist the Indochinese refugees in China. On December 1, 1995, the Task Office was upgraded to a Mission Office, which was further upgraded to a Regional Office in May 1997. Nowadays, the UNHCR Regional Office in Beijing covers China (including Hong Kong and Macau, not including Taiwan) and Mongolia. Additionally, UNHCR maintains a Sub-Office in Hong Kong. ${ }^{279}$ The relations between China and UNHCR will be further discussed in Chapter V.

\section{Regional Developments}

\section{A Africa, Latin America, and Europe}

In the mid-1960s, a number of developing countries voiced their dissatisfaction with the Convention's inadequacy to reflect the reality in the Third World. ${ }^{280}$ While the Protocol may be seen as the response to these situations at the international level, the regional response was the OAU Convention in 1969 in Africa and the Cartagena Declaration in 1984 in Central and Latin America.

\footnotetext{
${ }^{275}$ UNHCR "EXCOM Membership by Admission of Members" UNHCR <http://www.unhcr.org/40112e984.html> (accessed 17 April 2014).

${ }^{276}$ Oral Statement of Prince Sadruddin Aga Khan, United Nations High Commissioner for Refugees, to UNHCR headquarters staff on 1 February 1972 (Geneva, 1 February 1972), available at UNHCR $<\mathrm{http}: / /$ www.unhcr.org/3ae68fb314.html $>$ (accessed 8 August 2012).

${ }^{277}$ Liang, above $\mathrm{n} 32$, at 252.

${ }^{278}$ Prior to 1979 , China refused to accept UN aid. Yongtu Long "Jieshou lianheguo de yuanzhu, jiushi jiehsou yizhong hezuo de jingitn [Accepting UN Assistance is Embracing Cooperation Spirit]" Hexun $<$ http://data.book.hexun.com/chapter-2482-3-6.shtml> (28 April 2014).

279 "China's Relationship with United Nations High Commissioner for Refugees (UNHCR)" (16 April 2004) Chinese Permanent Mission to Geneva <http://www.china-un.ch/eng/rqrd/jblc/t85094.htm> (accessed 12 March 2013).

${ }^{280}$ Betts et al, above n 258, at 30 .
} 
The OAU Convention developed a broader refugee definition which was based on the experience of the wars of liberation and decolonisation in Africa during the late 1950s and early 1960s. ${ }^{281}$ Article I of the OAU Convention incorporates the Convention definition and further provides that:

the term "refugee" shall also apply to every person who, owing to external aggression, occupation, foreign domination or events seriously disturbing public order in either part or the whole of his country of origin or nationality, is compelled to leave his place of habitual residence in order to seek refuge in another place outside his country of origin or nationality.

The Cartagena Declaration was adopted to cope with the mass displacement caused by civil strife in Central and Latin America. ${ }^{282}$ It also introduced a broader definition. Part III of the Cartagena Declaration recommends that a refugee definition:

in addition to containing the elements of the 1951 Refugee Convention and the 1967 Protocol, includes among refugee persons who have fled their country because their lives, safety or freedom have been threatened by generalised violence, foreign aggression, internal conflicts, massive violation of human rights or other circumstances which have seriously disturbed public order.

Although the Cartagena Declaration is not a binding treaty, the wider refugee definition outlined in the Cartagena Declaration has been incorporated into national laws by many countries in the region. $^{283}$

The OAU Convention and Cartagena Declaration were adopted in response to frequent largescale forced migration movements in the Africa and Central and Latin Amercia respectively. As Arboleda has noted, both documents "conform with the tenets of humanitarianism, as well as the dictates of pragmatism". 284

A more recent effort to develop the refugee concept at the regional level is the EU Qualification Directive. Instead of adopting a broader refugee definition, the EU Qualification Directive incorporates the Convention Definition in art 2(d) and provides "subsidiary protection" to any third country nationals or stateless persons under art 2(f): ${ }^{285}$

\footnotetext{
${ }^{281}$ UNHCR, above n 268, sec 1.2.2.1.

282 Zimmermann and Mahler, above n 105, at 318.

283 Tristan Harley "Regional Cooperation and Refugee Protection in Latin America: A 'South-South' Approach" (2014) 26(1) International Journal of Refugee Law 22 at 24.

${ }^{284}$ Eduardo Arboleda "Refugee Definition in Africa and Latin America: The Lessons of Pragmatism" (1991) 3(2) International Journal of Refugee Law 185, at 186.

${ }^{285}$ Serious harm is defined under art 15 of the EU Qualification Directive as (a) death penalty or execution; or (b) torture or inhuman or degrading treatment or punishment of an applicant in the country of origin; or (c) serious and
} 
who does not qualify as a refugee but in respect of whom substantial grounds have been shown for believing that the person concerned, if returned to his or her country of origin, or in the case of a stateless person, to his or her country of former habitual residence, would face a real risk of suffering serious harm as defined in Article 15, and to whom Article 17(1) and (2) does not apply, and is unable, or, owing to such risk, unwilling to avail himself or herself of the protection of that country

Goodwin-Gill and McAdam have noted that the EU Qualification Directive merely distils State practice rather than creates a new protection system, ${ }^{286}$ and have pointed out that, with few exceptions, western countries typically "eschewed the incorporation of additional categories into the Convention refugee concept". ${ }^{287}$

$B$

Asia

Asia hosts a significant portion of the world's refugee population. However, the majority of Asian countries have not acceded to the Convention and Protocol, ${ }^{288}$ showing constant resistance to these instruments. ${ }^{289}$ As pointed out by UNHRC, a lack of understanding of refugee issues generally hinders the promotion of a favourable refugee protection environment in Asia. ${ }^{290}$ Refugee flows are dealt with primarily as issues of State security and political process in Asia. ${ }^{291}$ Kneebone has rightly noted that in Asia "refugees have long been associate with threats to national sovereignty and identity, ... rather than as victims of human rights abuse". ${ }^{292}$ As a result, although the overall Asian region is looking for solutions for large-scale refugee movements in

individual threat to a civilian's life or person by reason of indiscriminate violence in situations of international or internal armed conflict.

${ }^{286}$ Goodwin-Gill and McAdam, above n 103, at 329.

${ }^{287}$ Goodwin-Gill and McAdam, above n 103, at 289.

${ }^{288}$ According to UNHCR, as at March 2014, 20 countries from the Asian Pacific region are parties to the Convention and Protocol. Among these countries, 12 are Asian. Asian State parties to the Convention and/or its 1967 Protocol and their date of accession are: Afghanistan (30 August 2005), Cambodia (15 October 1992), China (24 September 1982), Iran (28 July 1976), Japan (3 October 1982/1 January 1982), Kazakhstan (15 January 1999), Kyrgyzstan (8 October 1996), Korea (3 December 1992), Philippines (22 July 1981), Tajikistan (7 December 1993), Timor-Leste (7 May 2003), and Turkmenstan (2 March 1998). UNHCR, above n 254, at 5.

${ }^{289}$ See generally Sara Davies Legitimising Rejection: International Refugee Law in Southeast Asia (Martinus Nijhoff, Leiden, 2008); Sam Blay "Regional Development: Asia" in Andreas Zimmermann (ed) The 1951 Convention Relating to the Status of Refugees and its 1967 Protocol: A Commentary (Oxford University Press, Oxford, 2011) 145, at 148; Taya Hunt and Nikola Errington "The Search for Protection in Southeast Asia" in Angus Francis and Rowena Maguire (ed) Protection of Refugees and Displaced Persons in the Asia Pacific Region (Ashgate, Farnham(UK), 2013) 53.

${ }^{290}$ UNHCR "2013 Regional Operations Profile - East Asia and the Pacific" UNHCR < http://www.unhcr.org/ pages/49e45b276.html> (accessed 14 July 2013).

${ }^{291}$ Pia Oberei "Regional Initiatives on Refugee Protection in South Asia" (1999) 11(1) International Journal of Refugee Law 193, at 197.

${ }^{292}$ Susan Kneebone "ASEAN and the Conceptualisation of Refugee protection" in Ademola Abass and Francesca Ippolito (ed) Regional Approaches to the Protection of Asylum Seekers: An International Legal Perspective (Ashgate, Farnham(UK), 2014) 295, at 298. 
the region, ${ }^{293}$ no regional arrangement specifically designed to tackle Asia's refugee problems has been achieved.

\section{$1 \quad$ The Bangkok Principles by the Asian-African Legal Consultative Organization}

The Asian-African Legal Consultative Organization (the AALCO) adopted a set of Principles concerning the Status and Treatment of Refugees (the Bangkok Principles) in Bangkok in 1966. The Bangkok principles are the only codified and comprehensive standards of refugee protection in Asia. ${ }^{294}$

The Bangkok Principles were revised in 2001. In the revised text of the Bangkok Principles adopted by the AALCO on 24 June $2001,{ }^{295}$ a refugee is defined in a way similar to the refugee definition in the OAU Convention. According to art 1(1) of the Bangkok Principles, a refugee is:

a person who, owing to persecution or a well-founded fear of persecution for reasons of race, colour, religion, nationality, ethnic origin, gender, political opinion or membership of a particular social group: (a) leaves the State of which he is a national, or the Country of his nationality, or, if he has no nationality, the State or Country of which he is a habitual resident; or, (b) being outside of such a State or Country, is unable or unwilling to return to it or to avail himself of its protection.

Article 1(2) further applies the term "refugee" to:

every person, who, owing to external aggression, occupation, foreign domination or events seriously disturbing public order in either part or the whole of his country of origin or nationality, is compelled to leave his place of habitual residence in order to seek refuge in another place outside his country of origin or nationality.

The Bangkok principles are declaratory and not legally binding. ${ }^{296}$ Although the refugee definition contained in the Bangkok Principles has not had a real impact on national refugee law in Asian countries, ${ }^{297}$ they form guiding principles for State practice and serve as a term of reference and an expression of the Asian-African region's concern for refugees. ${ }^{298}$ For example, the government of Pakistan referred to the refugee definition contained in the Bangkok Principles when explaining its policy towards refugees from Afghanistan in 1981. ${ }^{299}$

\footnotetext{
293 Zimmermann and Mahler, above n 105, at 320.

${ }^{294}$ Oberei, above n 291, at 197.

${ }^{295}$ Final Text of the AALCO's 1966 Bangkok Principles on Status and Treatment of Refugees, as adopted on 24 June 2001 at the AALCO's 40th Session, New Delhi”, available at Refworld $<$ www.refworld.org/docid/3de5f2d52.html > (accessed 6 April 2014).

${ }^{296}$ At Introductory Remarks 2, Notes, Comments and Reservations Made by the Member States of AALCO.

${ }^{297}$ Zimmermann and Mahler, above n 105, at 320; Muntarbhorn, above n 51, at 47.

${ }^{298}$ AALCO Secretariat "The Status and Treatment of Refugees" (2009), AALCO/48/putrajaya/2009/s 3, at [2].

${ }^{299}$ Oberei, above n 291, at 195.
} 
There are two regional inter-governmental processes in the Asia-Pacific region relevant to refugees. One is the Inter-governmental Asia-Pacific Consultations on Refugees, Displaced Persons and Migrants (APC). The other is the Bali Ministerial Conference on People Smuggling, Trafficking in Persons and Related Transnational Crime (Bali Process).

The APC was originally convened in 1996 by the Australian government to provide a forum for Asian-Pacific governments, who seek regional cooperation on matters relating to population movements, including movements of refugees, displaced persons and migrants. With regard to refugee matters, the APC focuses on comprehensive and durable solutions for refugee situations. ${ }^{300}$ The APC has 34 members, including China and Myanmar. ${ }^{301}$ UNHCR and the International Organization for Migration (IOM) are both observers of the APC. The APC is inactive at present; the last APC plenary was held in 2006 in China. ${ }^{302}$

Established in 2002, the Bali Process is a voluntary forum with 45 members, including China, Myanmar, Pakistan, Afghanistan, UNHCR, and IOM. ${ }^{303}$ A core objective of the Bali Process is to assist States to adopt best practices in asylum management, in line with the Refugee Convention. ${ }^{304}$ In March 2011, Bali Process Ministers endorsed a Regional Cooperation Framework to enable interested members to develop practical bilateral or sub-regional arrangements aimed at enhancing responses to irregular migration through consistent processing of asylum claims, durable solutions for refugees and sustainable return of persons ineligible for protection. ${ }^{305}$ A Regional Support Office has been opened in Bangkok in September 2012 to facilitate implementation of the framework. ${ }^{306}$

The APC and the Bali Process are informal and non-binding in character and discussions under these processes are confidential. ${ }^{307}$ However, as Oberio has observed, the very fact that governments feel compelled to participate (or be seen participating) is itself recognition on their part of the value of the processes addressing refugee issues. ${ }^{308}$

C China's Involvement at Regional Level

China joined the AALCO in 1983 and has maintained a friendly and cooperative relation with the AALCO. ${ }^{309}$ Prior to joining the organisation, it was invited to participate in the AALCO's

\footnotetext{
300 “APC's Focus" Asia-Pacific Consultations on Refugees, Displaced Persons and Migrants (APC) $<$ http://www.apcprocess.net/aboutus.htm $>$ (accessed 9 April 2014).

301 “APC" International Organization for Migration (IOM) $<$ https://www.iom.int/cms/en/sites/iom/home/what-wedo/regional-processes-1/rcps-by-region/apc.html> (accessed 9 April 2014).

302 "APC", above n 301.

303 "About the Bali Process" Bali Process <http://www.baliprocess.net/> (accessed 9 April 2014).

304 "About the Bali Process", above n 303.

305 "About the Bali Process", above n 303.

306 "Regional Support Office" Bali Process <http://www.baliprocess.net/regional-support-office> (accessed 23 April 2014).

${ }^{307}$ Joyce Chia and Susan Kenny "The Children of Mae La: Reflections on Regional Refugee Cooperation” (2012) 13 Melbourne Journal of International Law 838, at 854.

${ }^{308}$ Oberei, above n 291, at 201.

309 "yafei falü xieshang zuzhi (AALCO) [Asian-African Legal Consultative Organization (ALLCO)]" (30 March 2006) People Web <http://world.people.com.cn/GB/8212/60991/60995/4254971.html> (accessed 6 April 2014).
} 
$21^{\text {st }}$ annual conference in Jakarta, Indonesia, as an observer and sent a delegation to the conference in 1980; it did the same twice in the following years. ${ }^{310}$ On 14 November 1983 , China became a member of the AALCO. ${ }^{311}$ Since then, China has been actively involved in the AALCO's activities. It hosted the AALCO 29 ${ }^{\text {th }}$ annual conference in Beijing in 1990 and several Chinese nationals have been the Secretary or Deputy Secretary of the AALCO. ${ }^{312}$

China contributed to the revised text of the Bangkok Principles. For example, following the adoption of the revised text of the Bangkok Principles in 2001, the AALCO adopted a resolution (RES/41/3) in 2002 which directed the AALCO Secretary-General to explore the possibility of convening a workshop in cooperation with UNHCR and led to a seminar on strengthening refugee protection during migratory movements in 2003. ${ }^{313}$ At this seminar, "interesting accounts of the refugee situation and preoccupations in several countries, in particular China, Egypt, India, Kenya, Syria and Tanzania", were listened to. ${ }^{314}$

The Chinese government has rarely, if ever, referred to or mentioned the Bangkok Principles domestically. The Bangkok Principles has not had obvious influence on Beijing's national refugee policy. However, China's willingness to participate in the discussion relating to the Bangkok Principles indicates China's recognition of the value of these Principles. As a member of the AALCO, China should give good consideration to the Bangkok Principles when framing its national refugee law and policy.

China has actively participated in the APC and Bali Process. It hosted the 2005 and 2006 APC plenaries. China has also sent delegates to a number of Bali Process Ministerial conferences. Given the informal and confidential nature of the APC and the Bali Process, it is difficult to assess the impact of these processes on China's refugee law and policy.

Besides participating in multilateral processes, China has shown emerging interest in involving refugee matters in bilateral dialogues with key players in the region. In February 2014, China's Vice Foreign Minister, Mr Li Baodong, criticised Australia's treatment of refugees during the $15^{\text {th }}$ bilateral human rights dialogue between China and Australia. ${ }^{315}$ It probably was the first time China initiated conversations on refugee issues with another countries. It may not be coincidence that the Chinese government invited the Melbourne-based International Detention Coalition to present about alternatives immigration detention in May 2013. ${ }^{316}$

\footnotetext{
310 "zhongguo yu yafei falü xieshang zuzhi [China and AALCO]” MFA <www.fmprc.gov.cn/tyfls/bjzl/t84239.html> (accessed 6 April 2014).

311 "AALCO", above n 309.

312 "China and AALCO", above n 310.

313 AALCO "Status and Treatment of Refugees", AALCO/43/BALI/2004/SD/S 3, Annex, at "Summary of Discussions", available at AALCO <http://www.aalco.int/refugees-2004.pdf $>$ (accessed 8 April 2013).

${ }^{314}$ AALCO, above n 313, at "Summary of Discussions".

315 "A Hypocritical, Hollow Critique" The Australian (online ed, 22 February 2014) $<$ http://www.theaustralian.com.au/opinion/editorials/a-hypocritical-hollow-critique/story-e6frg71x1226834198413?nk=435b3b55a6999c3aea51f56645fd3005> (accessed 20 March 2014).

316 International Detention Coalition "Annual Report 2013" (2013) International Detention Coalition $<$ http://idcoalition.org/publications/2013-annual-report/> (accessed 25 April 2014) at 14.
} 


\section{Conclusion}

The Convention and Protocol allow significant freedom for State parties to interpret the Convention Refugee Definition. This mechanism of the Convention and Protocol is a doubleedge sword. On the one hand, it leads to varying treatment of refugees; on the other hand, it gives the continuing relevance to the Convention and Protocol.

Many of the issues relating to the interpretation and application of the Convention Refugee Definition remain open. Like any other State parties to the Convention and Protocol, China is entitled to interpret and apply the Convention Refugee Definition based on its own understanding of these documents and to establish a RSD mechanism tailored to the situation in China. However, China also has the obligation to apply the Convention Refugee Definition in good faith and in line with the purposes of the Convention and Definition.

China has demonstrated a growing interest in engaging in the international refugee protection regime, especially at the regional level. As China increasingly pursues conversations and cooperation with the international community, it is inevitable that China's conception of the Convention Refugee Definition will evolve; on the other hand, China's potential to influence the international refugee protection regime can be realised through frank conversations and constructive cooperation with the international community. 


\section{Chapter III Legal Context of Refugee Status in China}

The traditional mistrust of law, lawyers, and courts among the Chinese, not only in China but elsewhere in Asia, should not be underestimated.

- Vitit Muntarbhorn ${ }^{317}$

\section{China's Legal System}

China does not have a Western-style separation of powers, ${ }^{318}$ where the legislative, executive, and judicial branches stand independently to restrain each other. In China, the legislative power is shared by more than one power organ. ${ }^{319}$ The National People's Congress (NPC) is the highest legislative organ in China. It is vested with the authority to amend the Constitution and to establish and amend basic laws governing criminal offences, civil affairs, the State organs and other matters in China. ${ }^{320}$ The NPC is also empowered to elect the President and the VicePresident of China, decide on the choice of the Premier of the State Council upon nomination by the President of China, and elect the President of the Supreme People's Court. ${ }^{321}$ The People's Congress at local levels are authorised to enact local legislation. The State Council is the Central Government of China. It is empowered to formulate administrative regulations, which are considered as part of the legislation in China. Governments at local levels are authorised to make local regulations.

According to the 2000 Chinese Law on Legislation, Chinese legislation can be divided into three tiers (art 79). ${ }^{322}$ Top tier legislation consists of laws (falü) made by the NPC or its Standing Committee (art 7); second tier legislation consists of administrative regulations (xingzheng fagui) made by the State Council (art 56); third tier legislation includes local regulations (difangxing fagui), ${ }^{323}$ autonomous regulations (zizhi tiaoli), separate regulations (danxing tiaoli), ${ }^{324}$ and rules

\footnotetext{
${ }^{317}$ Muntarbhorn, above $\mathrm{n} 51$, at 61.

${ }^{318}$ Ronald C Keith and Zhiqiu Lin "Judicial Interpretation of China's Supreme People's Court as 'Secondary Law' with Special Reference to Criminal Law" (2009) 23 China Information 223 at 246; "China's Current Legislation Structure" (2003) China Net <http://www.china.org.cn/english/kuaixun/76212.htm> (accessed 12 April 2014).

319 "China's Current Legislation Structure", above n 318.

${ }^{320}$ Article 62(1) and (3), Constitution of the People's Republic of China 1982. English version of the 1982 Constitute is available at the National People's Congress $<$ http://www.npc.gov.cn/englishnpc/Constitution/node_2825.htm> (accessed 1 April 2014).

${ }^{321}$ Article 62(4), (5) and (7).

${ }^{322}$ Official English version of the 2000 Chinese Legislation Law is available at the Chinese Central Government's website, <http://english.gov.cn/laws/2005-08/20/content_29724.htm> (accessed 25 Mar 2014).

${ }^{323}$ The People's Congress or its standing committee at provincial and municipal levels are authorised to make local regulations (art 63).

${ }^{324}$ The People's Congresses of autonomous regions at provincial, prefectural or county level are authorised to formulate autonomous regulations and separate regulations (art 66). There are five autonomous regions at the provincial level, namely Guangxi Zhuang Autonomous Region, Tibet Autonomous Region, Xinjiang Uighur Autonomous Region, Inner Mongolia Autonomous Region, and Ningxia Hui Autonomous Region.
} 
(guizhang). ${ }^{325}$ In this thesis, unless otherwise indicated or implied by the context, the term Chinese law refers to Chinese legislation in general rather than just the laws made by the State Council.

China's legal system is similar to a civil law model. In theory, a decision of a Chinese court will not bind another Chinese court, but in practice, judges of lower courts usually try to follow the interpretations of the laws decided by the Supreme People's Court. ${ }^{326}$ From time to time, the Supreme People's Court issues so-called judicial interpretations, which contain the Supreme People's Court's opinion on legal matters. These judicial explanations are generally considered practically to serve as a source of law, ${ }^{327}$ and hence binding on lower courts.

China is in the transition to rule of law. Prior to China's reform and opening up in 1979, law had often been neglected or abused for decades in China, and the governance of the country had heavily relied on the policy of the Chinese Communist Party, especially during the Cultural Revolution (1966-1976). For example, prior to 1976 China lacked even the most basic laws, such as a comprehensive criminal code or a contract law, ${ }^{328}$ and the Ministry of Justice, which was dismantled in 1959, was re-established only in $1979 .{ }^{329}$ In the past three decades, China has made remarkable progress in building up a body of legislation and legal institutions. However, Peerenboom has rightly noted that there is evidence that the legal system in China remains a type of rule by law rather than a form of rule of law, indicating that in China law remains merely a tool to be used as the government sees fit rather than imposing meaningful restraints on the government and individual members of the ruling elite. ${ }^{330}$ Nowadays, in some cases, law is still ignored by authorities or trumped by party policy.

It should be pointed out that Hong Kong, Macau, and Taiwan each has a different legal system from China mainland. Hong Kong, a British colony until 1997, maintains a common law system. Macau, a Portuguese colony until 1999, has a civil law system which is based on the Portuguese legal system. Hong Kong and Macau enjoy highly autonomous legislative powers and independent judicial powers according to the Basic Law of Hong Kong Special Administration Region (art 2) and the Basic Law of Macau Special Administration Region (art 2) respectively. Taiwan has a civil law system. China claims that Taiwan is a province of China, but has not exercised sovereign power on Taiwan since 1949.

\footnotetext{
${ }^{325}$ Ministries and commissions of the State Council, the People's Bank of China, the State Audit Administration as well as the other organs endowed with administrative functions directly under the State Council are authorised to formulate rules (article 71).

${ }^{326}$ Susanna Fischer "A Brief Introduction to the Legal System of China" (2002) The Catholic University of America $<$ http://faculty.cua.edu/fischer/ComparativeLaw2002/bauer/China-main.htm> (accessed 12 April 2014).

${ }^{327}$ See eg Keith and Lin, above n 318, at 224; Jinrong Wang "On the Judicial Interpretation of China's supreme People's Court" (1995) 3 China L 9, cited from Li Wei "Judicial Interpretation in China" (1997) 5 Willamette Journal of International Law and Dispute Resolution 87 at 87; Shibing Cao "The Legal Status of Decisions and Judicial Interpretations of the Supreme Court of China" (2008) 3(1) Frontiers of Law in China 1 at 2. Both Wang and Cao were working for the Supreme Court of China when they wrote their article.

${ }^{328}$ Randall Peerenboom China's Long March toward Rule of Law (Cambridge University Press, Cambridge, 2002) at 6.

${ }^{329}$ Peerenboom, above n 328, at 7 .

${ }^{330}$ Peerenboom, above n 328, at 8 .
} 
It has been made clear in the Introduction above that this thesis focuses on China mainland only. However, given that relevant law or administrative procedures in Hong Kong and Macau are likely to serve as references when China contemplates its own refugee law because of close political, economic and cultural links and geographic proximity between China and Hong Kong and Macau, relevant Hong Kong and Macau laws and procedures are discussed in this chapter.

\section{Immigration Control \\ A Underdevelopment of Chinese Immigration Law}

Generally speaking, a State's immigration law is of particular relevance to refugee protection in that State. China does not have a codified immigration law. Chinese immigration rules are scattered among a number of laws and regulations. ${ }^{331}$

Traditionally, China has offered few channels for foreigners to migrate to China. Prior to 2004, there were no legal provisions regarding permanent immigration to China and foreigners could not apply for permanent residence. ${ }^{332}$ The Administrative Measures for the Examination and Approval of Foreigners' Permanent Residence in China promulgated in 2004 was the first of its type in China, however, the criteria for permanent residence of foreigners in China set out in the Measures have been described as "harsh" and "strict". ${ }^{333}$ Unsurprisingly, immigration law has not had a prominent position in China's legal system.

\section{B General Provisions of the 2012 Exit and Entry Administration Law}

Prior to 1 July 2013, China regulated the exit and entry of aliens and Chinese citizens respectively in the 1985 Law on Administration of the Entry and Exit of Aliens (the Aliens ExitEntry Law), ${ }^{334}$ and the 1986 Law on Administration of Entry and Exit of Chinese Citizens. These two laws were superseded by the 2012 Exit and Entry Administration Law (the Exit-Entry Law) which entered into force on 1 July 2013.

Both the Alien Entry-Exit Law and the Exit-Entry Law contain articles specifically addressing asylum or the treatment of refugees and asylum seekers, which will be discussed in section III B of this Chapter. The discussion here deals with relevant general immigration control measures provided under the Exit-Entry Law, which are likely to be applicable to refugees in the absence of a sufficient refugee protection mechanism as is the status quo in China.

\footnotetext{
${ }^{331}$ For further reading on Chinese immigration law, see generally Liu, above $\mathrm{n} 15$.

332 They can obtain a long-term residence permit which allows them to legally stay in China for as long as five years.

${ }^{333}$ From 2004 to 2011, it was estimated that only about 2,000 foreigners successfully applied for permanent residence in China. Many people also believe that given China's large population, there is no need to encourage immigration of foreigners. Grace Ng "Red Tape Foils Green Card Dreams in China" (4 April 2012) The Jakarta Globe <http://www.thejakartaglobe.com/archive/red-tape-foils-green-card-dreams-in-china/> (accessed 28 April 2014); "zhuanjia cheng zhongguo weilai chengwei xin yiminguojia kenengxing da [Expert Says it is Highly Possible that China Would Become a New Immigration Country in the Future]" (30 June 2010) Sina $<$ http://news.sina.com.cn/c/sd/2010-06-30/115120579697.shtml> (accessed 28 April 2014).

334 English version of the law is available at Chinese Government website <http://english.gov.cn/200508/21/content_25035.htm> (accessed 1 April 2014).
} 
According to the Exit-Entry Law, foreigners are normally required to apply for a visa at Chinese visa-issuing authorities outside China (art 15). ${ }^{335}$ Chinese border authorities have the right to inspect the passport, visa and other relevant documents of a foreigner entering China and to refuse the entry of certain types of foreigners under art 25 and art 21 of the Exit-Entry Law. ${ }^{336}$ Chinese border authorities are not required to give reasons for denying entry (art 25), and are empowered to "force the return of those who refuse to do so" (art 26). These provisions, in the absence of relevant safeguards, may lead to refoulement prohibited by art 33 of the Convention or return to torture prohibited by art 3 of the Convention against Torture.

Public security bureaus (county level or above) and border authorities are authorised to detain foreigners who are suspected of illegal entry or overstay, for up to 30 days and under certain circumstances, up to 60 days (arts 58,60). Foreigners who illegally enter, stay in, and work in China may be subject to a variety of punishments varying from oral warning to fines, detention and deportation (arts 72, 76, 78, 80, 81).

The Exit-Entry Law, like other Chinese laws, generally does not distinguish refugees and asylum seekers from other migrants. Therefore, in the absence of a national refugee protection mechanism, refugees and asylum seekers entering or staying in China without valid documents are not likely be exempted from these measures. As a result, the provisions of the Exit-Entry Law fall short of providing sufficient protection against penalisation in line with art 31 of the Convention.

\section{Criminalisation of Unauthorised Departure and Entry under the 1997 Criminal Law}

In accordance with art 322 of the 1997 Criminal Law, unauthorised border crossing, including authorised departure and entry of the territory of China, is a crime if the circumstances are considered serious: ${ }^{337}$

Whoever violates the laws and regulations controlling secret crossing of the national boundary (border), and when the circumstances are serious, ${ }^{338}$ shall be sentenced to not more than one year of fixed-term imprisonment and criminal detention or control.

\footnotetext{
${ }^{335}$ There are a few exceptions, which will be discussed in sec III B of this chapter.

${ }^{336}$ Article 25: "Under any of the following circumstances, foreigners shall not be allowed to enter China: (1) Hold no valid exit/entry documents, or refuse or evade border inspection; (2) Are involved in any of the circumstances specified in Subparagraph (1) through (4) of the first paragraph of Article 21 of this Law; (3) May engage in activities not conform to the types of visa after entering China; or (4) Other circumstances in which entry is not allowed in accordance with laws or administrative regulations." Article 21(1)-(4): "Under any of the following circumstances, visas shall not be issued to foreigners: (1) Was deported, or was repatriated upon decision, and the No-Entry-into-China period has not expired; (2) Is suffering from serious mental disorders, infectious tuberculosis or other infectious diseases that may severely jeopardize the public health; (3) May endanger China's national security or interests, or disrupt social and public order, or engage in other illegal or criminal activities; (4) Resort to fraudulent acts in visa application or cannot guarantee expected expenditures during their stay in China".

${ }^{337}$ Official English translation, available at the official website of the Chinese Ministry of Foreign Affairs $<$ http://www.fmprc.gov.cn/ce/cgvienna/eng/dbtyw/jdwt/crimelaw/t209043.htm> (accessed 17 July 2014).

${ }^{338}$ According to the Supreme Court of China Judicial Explanation of Several Issue of Application of Law relating to the Hearing of Criminal Case of Organising or Transporting People Illegally Crossing National Boundary (Border), the following circumstances are considered "serious": (1) commit actions abroad which damage the interest of the China; (2) Illegally cross national boundary (border) for more than three times; (3) persuade or entice other people to illegally cross national boundary (border) together; (4) in the case of persons who receive administrative
} 
Article 322 penalises illegal departure and entry on an equal foot, and, as Muntarbhorn has noted, ${ }^{339}$ penalisation of unauthorised border crossing under Chinese criminal law is applicable to both Chinese nationals and foreigners.

However, $\mathrm{Yu}$ has noted that the interpretation and application of this provision has clearly focused on penalising unauthorised departure instead of unauthorised entry. ${ }^{340}$ He pointed out that from 1949 to the 1980s, illegal entry into China was very rare whereas China faced huge pressure of unauthorised exit of Chinese nationals, the exodus of residents in Guangdong Province to Hong Kong from the 1960 s to the 1980 s being a pertinent example. ${ }^{341}$ Interestingly, he has argued that Chinese nationals, who illegally exit China and apply for asylum in other countries based on fabricated evidence of having been persecuted in China, commit an offence under art $322 .^{342}$

\section{Existing Legal Provisions relating to Refugees and Asylum}

China does not have a separate refugee law or any domestic legal provisions pertaining to refugee definition or RSD. Though it acceded to the Convention and Protocol in 1982, it has not enacted any domestic legislation to codify its obligations under these instruments.

Existing provisions relevant to refugees and asylum are rare and scattered in the Chinese domestic law system. The legal basis for refugee protection in China is commonly considered to be art 32(2) of the 1982 Constitution and art 46 of the 2012 Exit and Entry Administration Law. Emergency Response Plans at national and local levels, though not specifically addressing the case of refugees or asylum seekers, have been followed by Chinese authorities to handle large scale influxes of displaced foreigners.

Before I start to explore the refugee definition in a legal context in China, it might be useful to look at the ordinary meaning of the term in Chinese language. The Chinese term for "refugee" is nanmin, which is the same as the Korean and Japanese term for "refugee", indicating that this term was probably introduced from another language. The term "nanmin" is defined in the authoritative Contemporary Chinese Language Dictionary as persons who are displaced and live in difficulty due to the impact of warfare and natural disasters. ${ }^{343}$

\section{A Article 32(2) of the 1982 Constitution}

The concept of asylum has been included in all constitutional documents of the People's Republic of China. The first constitutional document of the People's Republic of China, the

punishment because of illegal crossing of national boundary (border), repeat illegal crossing in less than a year's time after their punishment; (5) other serious circumstances.

${ }^{339}$ Muntarbhorn, above n 51, at 62.

${ }^{340}$ Zhigang Yu "chengshi guojia de guojihua yu toudufanzui de xingshi zhengce [The Internationalisation of States and Cities and the Criminal Policy regarding Illegal Border Crossing" (2014) 2 Qinghua University Journal 101, at 112.

${ }^{341} \mathrm{Yu}$, above $\mathrm{n} 340$, at 115.

${ }^{342}$ However, he has noted that in practice, such people are not prosecuted and that it would be difficult to obtain evidence. Yu, above $\mathrm{n} 340$, at 115 .

${ }^{343}$ Chinese Academy of Social Science Institute of Linguistics Dictionary Department xiandai hanyu cidian [Contemporary Chinese Language Dictionary] (The Commercial Press, Beijing, 1996) at 367. 
1949 Common Program of the Chinese People's Political Consultative Conference (1949 Common Program), ${ }^{344}$ provided in article 60 that "The People's Republic of China should grant the right of residence to foreigners who are persecuted by the government of their home country because of their participation in peace and democracy movements for the interest of the people and seek asylum in China". Article 99 of the 1954 Constitution stipulates that "The People's Republic of China grants the right of residence to any foreigner who is persecuted because of her support for justice, participation in peace movements or conduct of scientific work", whilst art 29 of the 1975 Constitution and art 59 of the 1978 Constitution both provide that " $[\mathrm{t}]$ he People's Republic of China grants the right of residence to any foreigner who is persecuted because of her support for justice, participation in revolutionary movements or conduct of scientific work".

The Constitution in force, which was promulgated on 4 December 1982 and last amended in 2004, is the first Chinese Constitution to employ the term "bihu [asylum]". Article 32(2) of the 1982 Constitution provides that "The People's Republic of China may grant asylum to foreigners who request it for political reasons." Comparing to provisions of its counterparts in previous Chinese constitutional documents, art 32(2) of the 1982 Constitution is less strongly worded and abstract.

First, the requirement of being persecuted, which was mentioned in corresponding articles in all previous Chinese constitutional documents, is absent in art 32(2) of the 1982 Constitution. Second, contrary to all previous Chinese constitutional documents, which gave relatively specific descriptions of the acts which would entitle the foreigner to asylum, the 1982 Constitution mentioned "political reasons" (zhengzhi yuanyin) as the only ground for a foreigner's request for asylum. Third, while the 1949 Common Program stated that China "should grant" the right of residence to persecuted foreigners and the 1954, 1975 and 1978 Constitutions provided that China "grants" to persecuted foreigners, the 1982 Constitution only stipulated that China "may grant" asylum. In light of how the verb "grant" is used, there seems to be a trend of decreasing commitment of the Chinese government to provide asylum to aliens in its constitutional documents from 1949 to 1982 (the year China acceded to the Convention and Protocol).

Article 32(2) of the 1982 Constitution is the only existing provision that Chinese domestic law contains in relation to the criteria for granting asylum in China. ${ }^{345}$ It has frequently been referred to as the legal ground for China's admission of refugees. ${ }^{346}$ It is clear that there is a gap between art 32(2) of the 1982 Constitution and the refugee definition under the Convention and Protocol.

\footnotetext{
${ }^{344}$ The 1949 Common Program of the Chinese People's Political Consultative Conference served as an interim constitution. After 1949, four Constitutions have been promulgated by the PRC successively on 20 September 1954 , 17 January 975, 5 March 1978 and 4 December 1982.

${ }^{345}$ There was a similar provision in the 1985 Law on Administration of Entry and Exit of Aliens (Alien Entry-Exit Law). The Alien Entry-Exit Law expired on 1 July 2013. See section III B of this chapter.

${ }^{346}$ See eg Liang, above n 32, at 259; Liu, above n 15, at 89; Muntarbhorn, above n 51, at 61; Yuanjun Wang "guanyu jianli woguo nanmin baohu falv zhidu de jidian sikao [Several Thoughts on Establishment of Refugee Protection Mechanism in China]"(2005) 12 Public Security Research 46 at 46; Chengdu Liu "dui gongan churujing guanli bumen jiaqiang nanmin guanli de jidian sikao [Several Thoughts on Improving Refugee Administration by
} 
On the one hand, art 32(2) of the 1982 Constitution mentions nothing of a person's fear of persecution, which is essential to the Convention Refugee Definition. This means a person does not need to be persecuted or at risk of persecution to be eligible for asylum in China. Existing literature provides little clue as to why the requirement of persecution was removed from art 32(2) of the 1982 Constitution. The requirement was included in the asylum article in all previous Chinese constitutional documents.

There is a possibility that this change was induced by China's experience in protecting persons who were not persecuted, but there is no evidence that China had provided asylum to such persons prior to the 1982 Constitution. Another possible explanation is that art 32(2) represents a much weaker commitment to provide asylum than any of its precedents in Chinese constitutional documents and hence the requirement of persecution was removed as a balancing effort. If one looks at art 32(2)'s precedents, one may find that China seemed to adopt a very welcoming attitude towards asylum seekers in its constitutional documents, which of course had something to do with the fact that few people requested for asylum in China at that time. For example, the 1949 Common Program created a constitutional obligation for China to provide asylum, stipulating that China should grant the right of residence to foreigners persecuted for certain reasons. The 1954, 1975 and 1978 Constitutions provided that China grants the right of residence to certain types of persecuted foreigners. In art 32(2) of the 1982 Constitution, granting asylum is clearly nothing more than a right that Chinese authorities can exercise at their discretion. Maybe that made the drafters of the 1982 Constitution feel that the requirement of persecution was not as necessary as before. Coincidentally or not, in a 1989 official reply from China's Ministry of Public Security (MPS) to a provincial ID card office, a refugee was defined in a way very similar to that of the Convention and Protocol, but the requirement of persecution was not mentioned (see sec IV of this chapter). ${ }^{347}$

On the other hand, while the Convention Refugee Definition recognises race, nationality, religion, political opinion and membership of social groups as grounds for a refugee's fear of persecution, art 32(2) of the 1982 Constitution limits the ground for requesting asylum in China to "political reasons". The phrase "political reasons" is not a legal term in China and is not defined in the Chinese legal context. It has only appeared in a very small number of Chinese laws and judicial explanations, ${ }^{348}$ most of which use the term without explanation or examples. Only a few examples of "political reasons" have been given in Chinese legal and judicial documents. According to the 2007 Interim Implementation Rules for Management of Stateowned Assets by Institutes Functioning Abroad (2007 Rules for Asset Management), political

Border Exit and Entry Administration Department of Public Security System]" (2000) 4 Journal of Beijing People's Police College 46 at 46; People's republic of China Combined seventh and eighth periodic reports on the Implementation of the Convention on the Elimination of All Forms of Discrimination against Women, CEDAW/C/CHN/7-8 (17 January 2013), at [224].

${ }^{347}$ MPS Security Management Bureau Reply to Jiangxi Province Resident ID Issuance Office's Enquiry about Whether to Issue ID Card to Refugees Returning to China 1989, GONGSAN[1989]NO350.

${ }^{348}$ According to searches in databases run by Peking University, the Supreme Court of China, and the Ministry of Commerce of China in April 2014. 
reasons included armed conflicts and riots in the host country and bilateral relations between China and the host country. ${ }^{349}$ In a 1985 judicial explanation on a real property dispute case, a person was considered to have not been able to claim her property right due to political reasons because her father in law was supressed during the land reform and her husband was imprisoned in a reform-through-labour jail. ${ }^{350}$

Another useful reference is provisions relating to asylum in previous Chinese constitutional documents, which limited provision of asylum to persons persecuted for reason of "participation in peace and democracy movements for the interest of people", "support for justice, participation in peace movements or conduct of scientific work" or "support for justice, participation in revolutionary movements or conduct of scientific work". There seems to be some degree of consistency in these provisions which means that the Chinese government might have had a consistent view of who are eligible for asylum in China. The drafters of the 1982 Constitution are likely to have considered and consulted these provisions. Therefore, it is possible that reasons for persecution enumerated in these provisions were an inspiration for the term "political reasons" in art 32(2) of the 1982 Constitution. Of course, these provisions should be understood in a historical context. For example, "conduct of scientific work" does not seem obviously political today, but at the height of the Cold War when atomic knowhow and military technologies were rapidly developing and commonly linked to a government's political leverage, conducting relevant scientific work could be highly political.

It may also be useful to look at the meaning of the term "political reasons" in a non-legal context. The term "political reason" is not defined in an authoritative Chinese language dictionary, the Contemporary Chinese Dictionary. Generally, "political reason" can be understood as any reason relating to politics. The term "politics" is defined in the Contemporary Chinese Dictionary as relations between classes, political parties, ethnic groups and states and their interrelations between each other. ${ }^{351}$ Therefore, in the Chinese language context, political reasons may refer to reasons relating to between classes, political parties, ethnic groups and states and their interrelations between each other.

Taken into consideration of the examples of "political reasons" given in the 2007 Rules for Asset Management, art 32(2) may, through interpretation, cover persons who are displaced by

\footnotetext{
${ }^{349}$ Article 26, the People's Republic of China Ministry of Finance (MOF) Interim Implementation Rules for Management of State-owned Assets by Institutes Functioning Abroad CAIXING[2007]NO559. Chinese version of the Rules is available MOF $<$ http://www.mof.gov.cn/zhengwuxinxi/caizhengwengao/caizhengbuwengao2008/caizhengbuwengao20082/200805 /t20080519 29058.html> (accessed 30 March 2014).

${ }^{350}$ The Supreme People's Court of China, Reply regarding the Real Estate Dispute between Fang Yishun, Fang Shengeng and the Central Production Team of Hengfeng Village, Wufeng Region, Qimen County, FAMINZI[85] NO $4, \quad$ available $\quad$ at $<$ http://policy.mofcom.gov.cn/blank/claw!fetch.action?id=g100002673\&industrycode=L07429;S09431\&secondcod $\mathrm{e}=711001 ; 552022>($ accessed 6 April 2014).

${ }^{351}$ Contemporary Chinese Language Dictionary, above n 343, at 1609. The Chinese term for "politics" is zhengzhi. When used in conjunction with another noun, the Chinese term zhengzhi can also mean "political", functioning as an adjective. In art 32(2) of the 1982 Constitution, the term "political reasons" is zhengzhi yuanyin in Chinese, yuanyin meaning reason(s).
} 
armed conflict and riots. In this sense, art 32(2) may provide protection to certain types of persons who are not protected by the Convention and Protocol. As will be discussed in sec $\mathrm{C}$ of this chapter, several emergency response plans made by county level governments in China actually highlight warfare or unrest as a cause of potential refugee influxes into China.

The coverage of art 32(2) of the 1982 Constitution would need to depend on Chinese authorities' interpretation of the article. Since art 32(2) of the 1982 Constitution has, however, never been invoked, at least not publicly, ${ }^{352}$ it is hard to tell how Chinese authorities interpret art 32(2) of the 1982 Constitution in relation to refugee definition. The refugee status of the Indochinese had been recognised by the Chinese government in August 1979; as will be discussed in Chapter IV, there is no evidence that the Chinese government referred to art 59 of the 1978 Constitution, which was in force at that time, as a ground for its recognition of the Indochinese's refugee status. Indeed, the Indochinese who came to China had been persecuted for being ethnic Chinese, and hence hardly fell within the spectrum of art 59 of the 1978 Constitution which protected those persecuted "because of her support for justice, participation in revolutionary movements or conduct of scientific work." A portion of Indochinese refugees arrived in China after 1982. While their forcible departure from Vietnam could be argued as to have been a result of political frictions between Vietnam and China, ${ }^{353}$ as Muntarbhorn pointed out, art 32(2) of the 1982 Constitution generally was not invoked in the large scale influx of Indochinese cases. ${ }^{354}$

After the Indochinese refugees, the Chinese government did not identify any refugees or publicly grant asylum to any person. ${ }^{355}$ There is no published record that Chinese authorities have screened any asylum seeker according to Chinese domestic law. ${ }^{356}$ Whereas its emphasis on the economic motivation of the North Korean escapees as the ground for denying them of refugee status seems to relate to art 32(2) of the 1982 Constitution, the Chinese government has never explicitly referred to art 32(2) of the 1982 Constitution to justify its position to the North Korean escapees. It has always merely stated generally that it has treated the North Korean escapees in China according to relevant international law, national law and the principle of humanitarianism (see chapter IV). It has not mentioned art 32(2) of the 1982 Constitution to justify its decisions on the status of the displaced ethnic minorities from Myanmar or any other displaced foreigners.

\footnotetext{
${ }^{352}$ Since granting asylum is regarded as a highly sensitive issue in China, it is not impossible that Chinese authorities granted asylum but have kept relevant information secret. It is impossible to verify whether article 32(2) was invoked in those unpublished asylum cases.

${ }^{353}$ See generally Paomin Chang Beijing, Hanoi, and the Overseas Chinese (University of California Institute of East Asian Studies, Berkeley, 1982); Michael Godley "A Summer Cruise to Nowhere: China and the Vietnamese Chinese in Perspective" (1980) 4 The Australian Journal of Chinese Affairs 35.

${ }^{354}$ Muntarbhorn, above $\mathrm{n} 51$, at 61.

355 "China has not promulgated laws or regulations relating to refugees and has no published precedents of screening asylum seekers or granting refugee status in accordance with domestic law." Guofu Liu "zhongguo weilai raobuguo nanmin yiti [China Cannot Avoid Refugee Issues in the Future]" (23 February 2012) Xinhua Net $<$ http://news.xinhuanet.com/world/2012-02/23/c_122744895.htm> (accessed 28 April 2014); "waiguoren ruhe dedao zhongguo 'bihu' [How Can Foreigners Receive Asylum in China]" (18 December 2013) Sohu News $<$ http://news.sohu.com/s2013/dianji-1291/> (accessed 11 April 2014).

${ }^{356}$ Liu, above n 355.
} 
By the time the 1982 Constitution was promulgated, China had acceded to the Convention and Protocol more than two months earlier. The majority of the Indochinese refugees had arrived and been settled. ${ }^{357}$ However, art 32(2) does not seem to take into consideration the Convention Refugee Definition or the Indochinese influx. A likely explanation is that asylum issues were not China's priorities in 1982. The country was still recovering from the ten year long chaotic Cultural Revolution (1966-1976) during which law was subordinated to policies. Intellectuals, including many law scholars, were persecuted; and foreigners were commonly viewed as spies and anti-revolutionary. It was also at the beginning of the "reform and open-up" process which begun in December 1978. Asylum and refugee issues were not China's priorities.

Another possible explanation is that the legislators were not ready to introduce those changes. As mentioned in chapter I, China's early experience in granting asylum mainly involved high profile politicians and was closely linked to political and diplomatic rivalry with the foreigner's country of origin. Even the acceptance of the Indochinese refugees was initially used to denounce Vietnam. ${ }^{358}$ Granting asylum might still be viewed as merely a means to serve political and diplomatic purposes by the Chinese legislators in 1982. Actually, as recently as 2000, an author from the Beijing Public Security Bureau's Border Exit and Entry Sector suggested in the Journal of Beijing People's Police College that political asylum may be given to the following types of persons: (1) high level state officials, (2) high officials of the UN, other internal organisations and foreign NGOs, (3) employees of foreign embassies, (4) influential leaders of opposite parties, politicians, well-known figures, (5) science and technology expert, famous scholars, militaries, social activists, (6) persons who have made outstanding contribution to China's scientific research, economic development or cultural exchange, (7) the family and relatives of the above and other foreigners. ${ }^{359}$ Given that the MPS and its local branches are among the major players in handling refugees and asylum seekers, ${ }^{360}$ the extent of media control in China and the sensitivity of the topic, the view of this author may, to a certain extent, represent the attitude of the Chinese government in 2000.

Whereas art 32(2) of the 1982 Constitution may be seen as a legal ground for the Chinese government to provide asylum, it is questionable whether asylum seekers may rely on it for their right to apply for asylum in China. After all, art 32 essentially only provides for the power of Chinese authorities to grant asylum, not the right of aliens to request asylum in China. No mechanisms have been established for the enforcement of an individual's constitutional rights in China. The Chinese Constitution primarily concerns itself with state organisational structure rather than the protection of fundamental rights of individuals. ${ }^{361}$ The right of citizens or organisations to challenge the constitutionality of government actions is not mentioned in the

\footnotetext{
${ }^{357}$ China received about 280,000 Indochinese, about 250,000 of who arrived between April 1978 and June 1979. Liang, above n 32, at 272.

${ }^{358}$ See ch IV.

${ }^{359}$ Liu, above n 346 , at 48 .

${ }^{360}$ The Chinese institutional framework for refugee and asylum matters is to be further discussed in chapter V.

${ }^{361}$ Jianfu Chen "Constitutional Judicialisation and Popular Constitutionalism in China: Are We There Yet?" in Guanghua Yu (ed) The Development of the Chinese Legal System (Routledge, Oxon, 2011) 3 at 4.
} 
Constitution. These factors make it difficult for individuals to exercise their constitutional rights. In addition, refugees and asylum seekers are not citizens of China. Whether they are entitled to constitutional rights under the Chinese Constitution and, if so, how they are going to exercise the constitutional rights remain in question.

\section{B Law on Exit and Entry Administration}

On 1 July 2013, the Exit-Entry Law, ${ }^{362}$ which was promulgated by the Standing Committee of the NPC on 30 June 2012, entered into force, superseding the Law of the People's Republic of China on Control of the Entry and Exit of Aliens (Aliens Entry-Exit and Law), ${ }^{363}$ and the Law on Administration of Exit and Entry of Chinese Citizens. The Alien Entry-Exit Law, which was promulgated on 22 November 1985 by the Standing Committee of NPC and entered into force on 1 February 1986, contained an article allowing asylum seekers to reside in China which stated "Aliens who seek asylum for political reasons shall be permitted to reside in China upon approval by the competent authorities of the Chinese Government." ${ }^{, 364}$ Prior to the Exit-Entry Law, this article, together with art 32(2) of the 1982 Constitution, was often referred to as the legal ground for refugee protection in China. ${ }^{365}$

The Exit-Entry Law is regarded as a combination of the two superseded laws as well as a reflection of the practice in the field. According to art 46 of the Exit-Entry Law, foreigners applying for refugee status may stay temporarily in China with temporary identity certificates issued by public security organs during the RSD process and foreigners recognised as refugees may stay or reside in China refugee identity certificates issued by public security organs. This is the first time China included provisions regarding the treatment of refugees in its domestic law. ${ }^{366}$

Article 46 of the Exit-Entry Law represents a step forward from art 15 of the Alien Entry-Exit Law in two senses. First, it explicitly recognises refugees' right to stay and live legally in China. Before the Exit-Entry Law, refugees' right to remain in China was not clearly stated under Chinese law. Article 32(2) of the 1982 Constitution and art 15 of the Alien Entry-Exit Law may be considered the legal ground for the right to stay of those who requested asylum from the Chinese government for political reasons, but they do not necessarily afford the same protection for those who are recognised as refugees or whose status is under consideration by UNHCR. In particular, UNHCR's definition of a refugee obviously is not limited to persons who request asylum for political reason and covers any person who is at risk of "serious and indiscriminate threats to life, physical integrity or freedom resulting from generalized violence or events

\footnotetext{
${ }^{362}$ English version of the law is available at Bureau of Exit and Entry Administration of the Ministry of Public Security <http://www.mps.gov.cn/n16/n84147/n84196/3837042.html> (accessed 1 April 2014).

${ }^{363}$ English version of the law is available at Chinese Government website <http://english.gov.cn/200508/21/content_25035.htm> (accessed 1 April 2014).

${ }^{364}$ Article 15.

${ }^{365}$ See Combined seventh and eighth periodic reports of China to UNCEDW, above $\mathrm{n}$ 346, at [224]; Liang, above $\mathrm{n}$ 32, at 259; Liu, above $\mathrm{n} 15$, at 89.

${ }^{366}$ UNHCR "Submission by the United Nations High Commissioner for Refugees For the Office of the High Commissioner for Human Rights' Compilation Report - Universal Periodic Review: People's Republic of China" (March 2013), Refworld <http://www.refworld.org/pdfid/5135b0cb2.pdf> (accessed 28 April 2014), at 1.
} 
seriously disturbing public order" ${ }^{367}$ As mentioned in chapter I, the Chinese government does not issue identity documents to UNHCR refugees. The legal status of UNHCR travel documents issued to refugees is unclear in China. ${ }^{368}$ Although in practice China allows UNHCR refugees to stay in China temporarily until a durable solution, usually resettlement, is found by UNHCR for them, ${ }^{369}$ UNHCR refugees' right to stay in China lacked sufficient legal protection under domestic Chinese law. Compared to Indochinese refugees who have been issued Chinese identity documents, ${ }^{370}$ UNHCR refugees are in a precarious situation. For example, in the early 1990s, more than 30 UNHCR refugees were repatriated along with illegal migrants by the Chinese government. ${ }^{371}$ Under art 46 of the Exit-Entry Law, refugees' rights to stay in China are explicitly recognised, which provides a legal ground for all refugees in China to stay or live in the country and lays a foundation for further improvement of the treatment of refugees in China.

Second, art 46 of the Exit-Entry Law identifies the authority in charge of issuing identity certificates to refugees and asylum seekers. Neither art 32(2) of the 1982 Constitution nor art 15 of the Alien Entry-Exit Law specifies which authorities are responsible for dealing with refugee matters. Liu has suggested the need for more detailed rules for enforcing art 15 of the Alien Entry-Exit Law, including the need to specify government organs in charge of refugee matters. ${ }^{372}$ Similarly, Wang pointed out that the lack of clear designation and distribution of responsibilities to authorities to handle refugee matters had hindered refugee protection and management in China. ${ }^{373}$ By stipulating that Chinese public security authorities are responsible for issuing identity certificates to refugees, art 46 of the Exit-Entry Law is the first Chinese legal provision relating to the national constitutional framework for refugee protection in China.

Certainly art 46 is a positive move to improve legal protection for refugees. The Exit-Entry Law, however, is silent on who qualifies as a refugee, which authorities are responsible for handling applications for refugee status or conducting RSD, or what the RSD procedures are. It will be sometime before we can tell whether and how refugees and asylum seekers can exercise their right under art 46. According to UNHCR, which has been advocating for national refugee protection legislation in China, a national asylum regulation should in principle shortly follow as an implementation tool. ${ }^{374}$ Given that art 46 covers only persons who are in the process of RSD and who have been granted refugee status, a prerequisite of exercising the right under this article is to have access to RSD procedures. If a person is not able to lodge an application for refugee

\footnotetext{
${ }^{367}$ UNHCR, above n 268, sec 3.1.4.

${ }^{368}$ Jerry Z Li and Sanzhuan Guo "China" in Dinah Shelton (ed) International Law and Domestic Legal Systems: Incorporation, Transformation, and Persuasion (Oxford University Press, Oxford, 2011)158, at 160; Wang, above n 346, at 47.

${ }^{369}$ UNHCR, above n 41.

${ }^{370}$ The Indochinese refugees were initially accepted as returning overseas Chinese nationals and to certain extent are still viewed as such by the Chinese government. That is the main reason they obtained Chinese identity documents and enjoy many civil rights that non-Indochinese refugees do not have. See Chapter IV.

${ }^{371}$ Liu, "Several Thoughts", above n 359, at 47.

${ }^{372}$ Liu, above n 359 , at 47.

${ }^{373}$ Wang, above n 346, at 47.

${ }^{374}$ UNHCR Regional Presentation for China and Mongolia "Fact Sheet" (September 2013) UNHCR < http://www.unhcr.org/500018e59.pdf> (accessed 28 April 2014).
} 
status, they will by no means be able to exercise the rights under art 46 . The new law is silent on who qualifies as a refugee and the procedures for refugee status application and determination. China has not established a mechanism for RSD and, as mentioned in chapter I, the Chinese authorities do not substantially involve themselves in RSD at present. UNHCR Beijing is the only organisation that currently conducts RSD in China (see chapter V). However, a significant proportion of de facto refugees and asylum seekers do not have access to UNHCR. For example, as mentioned above, China has repeatedly declined UNHCR's request to access the North Korean escapees and the displaced Kokangs and Kachins. The lack of a national RSD mechanism and restricted access to UNHCR hinders de facto refugees and asylum seekers from enjoying the rights under art 46 of the Law on Exit and Entry Administration. As said by a UNHCR refugee in Beijing, "it remains to be seen how China will implement these new provisions and whether refugees will receive the protection they are entitled to". ${ }^{375}$

Additionally, the Exit-Entry Law seems to leave room for the possibility of temporary and humanitarian protection. Normally, all aliens who wish to enter China need to apply for a visa at China's visa authorities overseas unless provided otherwise by the law (art 15). As an exception, art 20 allows foreigners to obtain a visa at certain ports for humanitarian reasons, and art 23 exempts foreigners from a visa under certain circumstances. According to art 20, aliens who need to enter China urgently for humanitarian reasons can apply for a so-called port visa ( $k o u$ 'an qianzheng) at certain Chinese ports. A port visa is valid for single entry and a stay for no longer than 30 days. According to art 23, aliens who enter China temporarily due to force majeure or other urgent reasons do not need a visa. Instead, they should go through the temporary entry formalities with the border defence and checking authorities at the border. ${ }^{376}$ Once admitted, they are allowed to stay in China up to 15 days. The law further provides that, subject to the approval of the border control department of the Public Security Bureau, aliens who need to change a temporary stay to a long-term stay in China for humanitarian reasons can obtain a residence permit (art 31).

These provisions, if constructively interpreted, may well serve as the legal basis for temporary and humanitarian protection for displaced foreigners who do not qualify for refugee status but are in need of international protection.

\section{Emergency Response Plans on Sudden Incidents Involving Foreign Factors}

In the aftermath of the SARS public health crisis in 2003, the Chinese government established a national emergency response system. The system consists of a National Overall Emergency Response Plan, 21 national category emergency response plans, 57 State Council departmental emergency response plans and emergency response plans at provincial, municipal, county, town

\footnotetext{
${ }^{375}$ Olivier Rukundo "China's New Exit-Entry Law” (1 October 2012) Fahamu Refugee Legal Aid Newsletter $<$ http://frlan.tumblr.com/post/32664470835/chinas-new-exit-entry-law> (accessed 19 April 2014).

${ }^{376}$ Border Control authorities can require the alien requesting temporary entry, the person in charge of the transport vehicle carrying the alien requesting entry across the border or the agent representing the transport vehicle in border crossing matters to provide necessary guarantee.
} 
and village levels. ${ }^{377}$ The 2005 National Emergency Response Plan on Sudden Incidents Involving Foreign Factors (National Plan) is one of the national category emergency response plans. In accordance with the National Plan, local plans on sudden incidents involving foreign factors (Local Plans, collectively the Plans) have been made at provincial, municipal, and county levels.

Though the Plans are not specific to the refugee situation, they are commonly regarded as the documents relied on by the Chinese government in response of refugee influxes. ${ }^{378}$ In practice, they have been followed by the Chinese government to deal with displaced minorities from Myanmar. For example, the Yunnan provincial authorities followed these plans to deal with the massive influx of ethnic Kokangs from Myanmar in 2009 in a timely and orderly manner. ${ }^{379}$ In April 2012, the government of Tengchong county Yunnan Province, a town bordering Myanmar's Kachin State, triggered its Local Plan to handle the influx of displaced Kachins. ${ }^{380}$

The full text of the National Plan has not yet been published, though it was launched in 2005, indicating the sensitive nature of the plan. ${ }^{381}$ Only the title of each chapter of the National Plan has been published. According to published chapter titles, the Nation Plan comprises seven chapters, namely General Principles, Organisation and Instructional Structures and Responsibilities, Whistle-blowing Mechanism, Classified Responses, Handling Procedures, Emergency Response Support and Supplementary Provisions.

Many of the Local Plans are available in full text. The structure of these plans and their provisions relating to refugees are generally similar. This indicates that these Local Plans might have been drafted following a certain model, most likely the National Plan. Several county level Local Plans, such as the plans of Yunnan Province's Lancang Country, Lushui County, Mengla County, Nujiang Prefecture and Wenshan Prefection list "large scale refugee influxes due to reasons like zhanshi [warfare] in neighbouring countries" as incidents that will trigger the plan (see Chart 6). ${ }^{382}$ Similarly, Tibet Autonomous Region's Shigatse Prefecture's Overall

\footnotetext{
${ }^{377}$ As of 5 March 2013. Source: the Central People's Government of China <www.gov.cn>.

${ }^{378}$ See eg Drew Thompson "Border Burdens: China's Response to the Myanmar Refugee Crisis" (2009) 5 China Security 11; Duanfang Tao "nanmin: zenyang bangzhu guojia de lingju? [Refugees: How to Help Our Country's Neighbours?]” NetEase <http://news.163.com/special/reviews/refugees.html> (accessed 20 April 2014); Bi Hu “ruhe jie 'nanmin' zhedao ti [How to Solve the Problem of 'Refugees']" Southern Weekly (online ed, Guangzhou, 3 September 2009).

${ }^{379}$ Thompson, above n 378, at 15.

${ }^{380}$ Emergency Response Management Office of the People's Government of Yunnan Province "jiceng yingji guanli shifan danwei Tengchong xian yingji guanli gongzuo shijian [Emergency Response Practice of Tengchong, A Model Basic-Level Unit in Emergency Response]" (26 October 2012) Environment Protection Department of Hunan Province <http://www.hbj.hunan.gov.cn/hjjc/hjyj/content_32894.html > (accessed 2 April 2014).

${ }^{381}$ It is not uncommon for Chinese authorities to not publish legal or policy documents as there is no effective system in China to ensure freedom of information. For example, according to a Chinese immigration law scholar, the majority of Chinese immigration laws, regulations and policies are "internal and not open for public scrutiny" because Chinese authorities usually treat immigration laws, regulations and policies as confidential. Liu, above $\mathrm{n} 15$, at 12 .

${ }^{382}$ Article 1.1.3, Office of Lushui County People's Government Notice on Circulation of Lushui County Emergency Response Plan on Sudden Incidents Involving Foreign Factors (2007) luzhengbanfa[2007]No.114, available at Lushui County Government Information Gateway $<$ http://xxgk.yn.gov.cn/canton_model19/newsview.aspx?id=362418> ; article 1.3(4), Mengla County Emergency
} 
Emergency Response Plan for Sudden Public Incident also lists "large scale refugee influx into border region due to reasons like dongluan [unrest] in neighbouring countries" as incidents which will trigger the plan.

These Local Plan Incidents are classified into four levels: extremely major (level 1), major (level 2), relatively major (level 3) and ordinary (level 4) in these five country-level plans. Level 1 emergencies are the most urgent and serious while level 4 emergencies are of the lowest urgency and severity. Refugee numbers triggering each level of emergency responses differ across counties and are as follows:

Chart 6 Trigger Level of Refugee Numbers in Local Emergency Response Plans

\begin{tabular}{|l|l|l|l|l|}
\hline Places applicable & Level 1 & Level 2 & Level 3 & Level 4 \\
\hline Lushui, Yunnan & Not mentioned & Not mentioned & Not mentioned & $20-50$ \\
\hline Mengla, Yunnan & 300 & $100-300$ & $50-100$ & $20-50$ \\
\hline Nujiang, Yunnan & Not mentioned & Not mentioned & $50-100$ & $20-50$ \\
\hline Wenshan, Yunnan & 300 & $100-300$ & $50-100$ & $20-50$ \\
\hline Shigatse, Tibet & Not mentioned & Not mentioned & Not mentioned & Not mentioned \\
\hline
\end{tabular}

It is worth noting that warfare or unrest in neighbouring countries are the only highlighted causes of refugee influxes in all plans which mention refugee influxes. While these plans are not intended to define a refugee, they seem to suggest that the Chinese government does not rule out the possibility of considering persons displaced by warfare and unrest from neighbouring countries as refugees. Of course, these Local Plans are made by county level governments in remote border provinces and do not necessarily represent the Central Government's view. The Chinese Central Government had clearly claimed that the displaced Kokangs or Kachins, who seem to fit the description of refugees in these Local Plans, were not refugees. ${ }^{383}$

\section{Applicable Multilateral and Bilateral Treaties \\ A The Convention and Protocol relating to the Status of Refugees}

China acceded to the Convention and Protocol in 1982. In theory, by acceding to the Convention and Protocol, China has made a commitment to be bound by the provisions of these instruments;

Response Plan on Sudden Incidents Involving Foreign Factors (2008), available at MengLa County Legal Office $<$ http://xsbnml.xxgk.yn.gov.cn/canton_model3/newsview.aspx?id=1441287>; article 1.1.3 Nujiang Prefecture Emergency Response Plan on Sudden Incidents Involving Foreign Factors (2007) nuzhengbanfa[2007]No.10, available at Nujiang Prefecture Office of Foreign Affairs and Oversea Chinese Affairs $<$ http://xxgk.yn.gov.cn/canton_model19/newsview.aspx?id=139359>; art I1(5), Wenshan Prefecture Emergency Response Plan on Sudden Incidents Involving Foreign Factors (2006) wenzhengbanfa[2006]No.108, available at People's Government of Wenshan Zhuang and Miao Autonomous Prefecture $<$ http://www.ynws.gov.cn/Detail.aspx?ID=13472>; Appendix article IV-3(2), Shigatse Prefecture Emergency Response Plan on Sudden Incidents (2008). All links were accessed on 2 April 2014.

${ }^{383}$ Due to the large size of China, it is not unusual that local level legislation and policy documents do not strictly comply with those at the national level. It has a longstanding problem through China's history. 
it also has the obligation to perform the Convention and Protocol in good faith according to the principle of pacta sunt servanda and the 1969 Vienna Convention on the Law of Treaties, ${ }^{384}$ to which China is a party.

In reality, China has not enacted any national law to implement the Convention and Protocol, except for art 46 of the exit-Entry Law. China's Constitution is silent on the legal status of treaties and their hierarchy in the domestic legal system. There has been no consensus among scholars on the legal status of treaties in China. ${ }^{385}$ According to Judge Xue Hanqin, of the International Court of Justice, strictly speaking, treaties ratified or acceded to by China do not automatically become part of Chinese domestic law and therefore do not automatically become enforceable in China. ${ }^{386}$ Judge Xue further pointed out that, generally speaking, except for those administrative agreements that can be directly executed, ${ }^{387}$ treaties can be applied domestically in China only after the adoption of legislation transforming a treaty into domestic law or authorizing direct application of the treaty. ${ }^{388}$ I agree with Judge Xue. Since China has not enacted any legislation to incorporate the provisions of the Convention and Protocol into Chinese law, the Convention and Protocol do not apply domestically in China. This means that refugees will not be able to bring a case to a Chinese court to enforce the provisions of the Convention and Protocol. In the event that Chinese authorities violate the provisions of the Convention and Protocol, there would be very limited remedies in the Chinese legal system available for refugees for violations of their rights under the Convention, such as of the right of not being returned to any place where their life or freedom would be threatened.

In addition, as mentioned in chapter II, the Convention and Protocol lack a strong monitoring mechanism. The institution charged with the task to supervise the implementation of the Convention and Protocol, UNHCR, unlike treaty supervisory bodies formed under a few human rights treaties, does not have the function of reviewing state reports or determining individual or inter-state complaints. It is "very much within a state party's sovereign discretion as to whether to take steps and, if so, which steps, to protect refugees within its jurisdiction". 389

\footnotetext{
${ }^{384}$ Article 26, "pacta sunt servanda", Vienna Convention on the Law of Treaties (concluded on 23 May 1969, entered into force on 27 January 1980).

${ }^{385}$ For discussions on domestic implementation of treaties in China, see eg Sanzhuan Guo "Implementation of Human Rights Treaties by Chinese Courts: Problems and Prospects" (2009) 8(1) Chinese Journal of International Law 161; Xiaoqing Zhu "guoji tiaoyue zai zhongguo guonei de shiyong yanjiu [Study on Application of International Treaties in China]" (20 June 2001) Bureau of International Cooperation of China Academy of Social Science

$<$ http://bic.cass.cn/info/Arcitle_Show_Study_Show.asp?ID=2257\&Title=\%B9\%FA\%BC\%CA\%CC\%F5\%D4\%BC $\% \mathrm{D} 4 \% \mathrm{DA} \% \mathrm{D} 6 \% \mathrm{D} 0 \% \mathrm{~B} 9 \% \mathrm{FA} \% \mathrm{~B} 9 \% \mathrm{FA} \% \mathrm{C} 4 \% \mathrm{DA} \% \mathrm{~B} 5 \% \mathrm{C} 4 \% \mathrm{CA} \% \mathrm{CA} \% \mathrm{D} 3 \% \mathrm{C} 3 \% \mathrm{D} 1 \% \mathrm{D} 0 \% \mathrm{BE} \% \mathrm{BF} \&$ strNavigat ion $=\% \mathrm{CA} \% \mathrm{D} 7 \% \mathrm{D} 2 \% \mathrm{~B} 3-\% 3 \mathrm{E} \% \mathrm{BF} \% \mathrm{BC} \% \mathrm{~B} 2 \% \mathrm{EC} \% \mathrm{D} 1 \% \mathrm{D} 0 \% \mathrm{BE} \% \mathrm{BF}-\% 3 \mathrm{E} \% \mathrm{CE} \% \mathrm{C} 4 \% \mathrm{BB} \% \mathrm{AF}>$ (accessed 22 September 2011); Yongwei Liu "guoji tiaoyue zai zhongguo shiyong xinlun [New Thoughts on Application of International Treaties in China]" (2007) 2 Faxuejia [Jurists Review] 143.

${ }^{386}$ Hanqin Xue and Qian Jin "International Treaties in the Chinese Domestic Legal System" (2009) 8(2) Chinese Journal of International Law 299, at 300.

${ }^{387}$ This refers to bilateral cooperation agreements and memoranda of understanding between governments, which qualify as international treaties under Chinese law. Xue and Jin, above n 386, at 306.

${ }^{388}$ Xue and Jin, above n 386, at 322 .

${ }^{389}$ Goodwin-Gill and McAdam, above n 103, at 528.
} 
Despite the lack of relevant national legislation, the Chinese government has repeatedly argued that it has duly implemented the Convention and Protocol. For example, it claimed in a 2008 State report on the implementation of the International Convention on the Elimination of All Forms of Racial Discrimination (Convention on Elimination of Racial Discrimination) that "China has been implementing the convention [relating to the Status of Refugees] in real earnest." ${ }^{390}$ In a 2010 report on the implementation of the Covenant on Economic, Social and Cultural Rights, it stated that: ${ }^{391}$

China is a state party to the 1951 Convention relating to the Status of Refugees and the 1967 Protocol relating to the Status of Refugees, ... [It] has provided international protection to refugees within its capacity, guaranteed their legitimate rights and interests to the greatest extent, .... .

As argued in chapter II, China might not have had a good understanding of its obligations under the Convention and Protocol or given a careful thought of its capacity and willingness to commit to these instruments. In fact, it seems that, after China acceded to the Convention, the lack of understanding of the Convention Refugee Definition, as well as of China's rights and obligations under these instruments, remained with Chinese authorities for a long time.

In 1989, seven years after China's accession to the Convention, the Jiangxi Province Resident ID Issuance Office submitted an enquiry to the MPS regarding the Indochinese refugees' eligibility for Chinese ID cards. In the enquiry, the Jiangxi office referred to the Indochinese refugees as "guiguo nanmin [refugees who returned to China]", obviously confusing the concept of refugees and returning huaqiao [overseas Chinese]. ${ }^{392}$ MPS in its reply pointed out that: ${ }^{393}$

Regarding people who reside in China as a "refugee", their nationality should be identified first. Refugees should refer to persons who, due to reasons of race, politics and religion, etc, stay outside of their country of origin, and are unable or unwilling to receive protection from that

\footnotetext{
${ }^{390}$ People's Republic of China 10th to 13th Periodic Reports on the Implementation of the International Convention on the Elimination of All Forms of Racial Discrimination, CERD/C/CHN/13 (24 June 2008), at [142].

${ }^{391}$ People's Republic of China Second Periodic Report on the Implementation of the Covenant on Economic, Social and Cultural Rights, E/C.12/CHN/2 (6 July 2012), [23].

${ }^{392}$ Between the $1950 \mathrm{~s}$ and $1970 \mathrm{~s}$, due to anti-Chinese movements in Indonesia and India, several waves of overseas Chinese nationals returned from those countries on ships sent by the Chinese government to collect them. Most Indochinese refugees are ethnic Chinese and they received treatment on a par with those Chinese nationals returning from Indonesia and India. This is probably the cause of the Jiangxi office's confusion. Glen Peterson argues that some Indonesian Chinese returning in 1960 might have gained Indonesian nationality and would seem to have fitted UNHCR's refugee definition quite closely. However, apart from the complex problems surrounding their nationality status, China seems to have regarded those for who it sent ships in the 1960s as Chinese nationals. See Peterson, above n 17; Lin Wen "xinzhongguo shouci daguimo cheqiao shimo [New China's First Large-scale Evacuation of Overseas Chinese]” (2012) 5 Wenshi Chunqiu [Literature and History] 17.

${ }^{393}$ MPS Security Management Bureau Reply to Jiangxi Province Resident ID Card Issuance Office's Enquiry about Whether to Issue ID Card to Refugees Returning to China 1989, GONGSAN[1989]NO350.
} 
country, including stateless persons who, due to such reasons, are unable to stay in their country of habitual residence, and unable or unwilling to return to that country.

The refugee defined in the reply looks similar to the Convention Refugee Definition. However, the requirement of well-founded fear for persecution, which is central to the Convention Refugee Definition, is not mentioned in the MPS reply. This seems to show the influence of art 32(2) of the 1982 Constitution, but it is difficult to tell whether the MPS merely neglected the requirement of persecution or intentionally omitted it. In addition, the reply did not mention membership of a particular social group, which is a ground for fear of persecution in the Convention Refugee Definition, and used the term "politics (zhengzhi)" rather than "political opinion (zhengzhi jianjie)", which is the phrase used in art $1 \mathrm{~A}(2)$ of the official Chinese version of the Convention. Though there are no sources to verify the reasons for such omission and changes, poor understanding of the Convention Refugee Definition is a possible explanation.

In 1992, the MPS issued a notice to provincial public security authorities on handling aliens illegally entering or staying in China (the 1992 Notice). ${ }^{394}$ The 1992 Notice mentioned that the number of Pakistanis, Iranians and Afghans illegally staying in China was increasing year by year and the most of these people, "using the excuse of escaping wars, applied for refugee status with UNHCR's office in China, and after registered with UNHCR, lived on charity provided by UNHCR." The notice required local level public security authorities to repatriate every and all aliens illegally entering or staying in China "regardless of whether they have registered with UNHCR", emphasising that "UNHCR shall not intervene in China's sovereign matters". According to Liu, in 1992, China repatriated 172 aliens illegally entering or staying in China, among whom were more than 30 UNHCR refugees. The 1992 Notice is obviously not in line with the Convention and Protocol and China clearly violated art 33 of the Convention by repatriating UNHCR refugees.

As mentioned in chapter I, since the mid-1990s, China has dealt with at least three massive inflows of displaced foreigners, namely the North Korean escapees, the displace Kokangs and the displaced Kachins. Generally, China has denied them refugee status and declined UNHCR's requests to access them. ${ }^{395}$ China's repatriation of the North Korean escapees and the displaced Kachins has been criticised by human rights groups as violations of the Convention and Protocol. There is no doubt that China, if it is to implement the Convention and Protocol in real earnest as it claimed, must make sure that it will not repeat the mistake of repatriating refugees as it did in 1992. However, due to the limitations of the Convention and Protocol, it is practically difficult for any third party to intervene in China's decisions on the treatment of refugees and other displace foreigners within its territory.

\footnotetext{
${ }^{394}$ MPS Notice on Taking Legal Actions Against Illegal Entry and Illegal Stay of Aliens (9 April 1992) GONGTONGZI[1992]NO39.

${ }^{395}$ China's treatment of these three groups will be further considered in ch IV.
} 
China is a party to most of the major international human rights treaties, including the Convention against Torture, Convention on Elimination of Racial Discrimination (adopted 21 December 1965, entered into force on 4 January 1969), Covenant on Economic, Social and Cultural Rights (opened for signature 19 December 1966, entered into force 3 January 1976), Geneva Convention (IV) Relative to the Protection of Civilian Persons in Time of War (opened for signature 12 August 1949, entered into force on 21 October 1950), Convention on the Rights of the Child (adopted 20 November 1989, entered into force 2 September 1990) and Convention on the Elimination of All Forms of Discrimination Against Women (adopted on 18 December 1979, entered into force on 3 September 1981).

Treaty supervisory bodies established under a number of these human rights treaties have raised refugee protection issues with China. ${ }^{396}$ For example, in its 2005 Concluding Observations, the Committee on the Rights of the Child urged China to amend relevant laws to allow children who were born to Indochinese refugees in China to obtain Chinese citizenship and to ensure that no unaccompanied children, including those from North Korea, are returned to a place where there are substantial grounds for believing that the children face a real risk of irreparable harm. ${ }^{397}$ The Committee again expressed concerns about the North Korean and Kachin children in China in its 2013 Concluding Observation: ${ }^{398}$

(a) Children entering mainland China from the Democratic People's Republic of Korea are still categorically considered as economic migrants and returned to the Democratic People's Republic of Korea without consideration of whether there are risks of irreparable harm to the children upon return;

(b) Children whose mothers are from the Democratic People's Republic of Korea lack legal identity and access to basic rights, particularly education, as they are not registered under the hukou system out of fear that their mothers would be identified and forcibly returned to the Democratic People's Republic of Korea;

\footnotetext{
${ }^{396}$ See eg Concluding Observations of the Committee on the Elimination of Racial Discrimination: China, A/56/18 (9 August 2001) at [246]; Concluding Observations of the Committee on the Elimination of Racial Discrimination: CHINA (including Hong Kong and Macau Special Administrative Regions), CERD/C/CHN/CO/10-13 (15 September 2009) at [9; 16]; Concluding Observations of the Committee against Torture: CHINA, $\mathrm{CAT} / \mathrm{C} / \mathrm{CHN} / \mathrm{CO} / 4$ (21 November 2008) at 8 and 11; Concluding Comments of the Committee on the Elimination of Discrimination against Women China, CEDAW/C/CHN/CO/6 (25 August 2006) at [33-34; 43-44].

${ }^{397}$ Committee on the Rights of the Child Concluding Observations: China (including Hong Kong and Macau Special Administrative Regions) $\mathrm{CRC} / \mathrm{C} / \mathrm{CHN} / \mathrm{CO} / 2$ (24 November 2005) at [82], available at United Nations Human Rights $<\mathrm{http} / /$ tbinternet.ohchr.org/_layouts/treatybodyexternal/Download.aspx?symbolno=CRC $\% 2 \mathrm{fC} \% 2 \mathrm{fCHN} \% 2 \mathrm{fCO} \% 2 \mathrm{f}$ 2\&Lang=en $>$ (accessed 27 April 2014).

${ }^{398}$ Committee on the Rights of the Child Concluding Observations on the Combined 3rd and 4th Periodic Reports of China, adopted by the Committee at its sixty-fourth session (16 September-4 October 2013), CRC/C/CHN/CO/3$4 \quad(29$ October 2013) at [81], available at United Nations Human Rights $<\mathrm{http}: / /$ tbinternet.ohchr.org/layouts/treatybodyexternal/Download.aspx?symbolno=CRC\%2fC $\% 2 \mathrm{fCHN} \% 2 \mathrm{fCO} \% 2 \mathrm{f}$ 3-4\&Lang $=$ en $>$ (accessed $2 \overline{7}$ April 2014).
} 
(c) The State party failed to recognize the Kachin asylum seekers, including children, as refugees despite their circumstances and forcibly returned them to Myanmar in August 2012;

(d) There is an absence of special reception procedures or facilities for unaccompanied and separated refugee and asylum-seeking children and that they lack access to health care, special care and protection.

The Committee on the Rights of the Child recommended China to respect the non-refoulement principle, cease arrest and repatriation of North Koreans, especially North Korean children, provide temporary protection to Kachin refugee children and their family, and allow UNHCR to access them. ${ }^{399}$

The Committee against Torture noted that many North Koreans in China were referred as "illegal immigrants" or "snakeheads" and had been forcibly returned "without any examination of the merits of each individual case". The Committee commented that, when determining the applicability of art 3 of the Convention against Torture, China: ${ }^{400}$

should establish an adequate screening process for status determination in order to determine whether persons subject to return may face a substantial risk of torture, particularly in view of the fact that it is reportedly a criminal offence to depart unofficially from the DPRK, and should provide UNHCR with access to the border region and persons of concern.

The Committee on the Elimination of Racial Discrimination also expressed its concerns about the treatment of North Korean asylum seekers in China and recommended China adopt appropriate national legislation to ensure protection for refugees and asylum seekers: ${ }^{401}$

the Committee reiterates its concern (A/56/18, para. 246) that asylum-seekers from the Democratic People's Republic of Korea continue to be systematically refused asylum and forcibly returned. (art. 5(b)).

The Committee recommends that the State party adopt legislation relating to refugee status as soon as possible. Bearing in mind its general recommendation No. 30, the Committee calls upon the State party to take all necessary legal and policy measures to ensure that all asylum-seekers have the merits of their individual cases considered by an independent and impartial authority.

In response to the comments of these human rights treaty bodies, China has politely but resolutely insisted that North Korean escapees in China are not refugees, and emphasised that China has provided refugee protection to the Indochinese refugees and has been working on

\footnotetext{
${ }^{399} \mathrm{CRC} / \mathrm{C} / \mathrm{CHN} / \mathrm{CO} / 3-4$, above n 398, at [83].

${ }^{400} \mathrm{CAT} / \mathrm{C} / \mathrm{CHN} / \mathrm{CO} / 4$, above n 396, at 11 .

${ }^{401} \mathrm{CERD} / \mathrm{C} / \mathrm{CHN} / \mathrm{CO} / 10-13$, above n 396, at [16].
} 
national refugee legislation. For example, it stated in a State report on the implementation of the Convention of the Rights of the Child that: ${ }^{402}$

The "children from the Democratic People's Republic of Korea", referred to in the Committee's concluding remarks, have illegally entered China's borders for economic reasons, and are not refugees. The Chinese Government has always dealt properly with cases concerning illegal entrants from the DPRK, in accordance with domestic law, international law and a humanitarian spirit, and giving full consideration to the actual circumstances of the persons involved.

It also stated in a State report on the implementation of the Implementation of the Convention on the Elimination of All Forms of Discrimination against Women that: ${ }^{403}$

Illegal immigrants from North Korea who come to China for economic reasons are not refugees. China has been handling individual cases in this regard in accordance with its domestic law, international law and in the spirit of humanitarianism, fully taking into account the actual situation of the persons involved. The dignity and rights of North Koreans who enter China by illegal means and for economic reasons are respected and they are treated in the spirit of humanitarianism, by providing them with necessities of life.

Generally, in these reports China simply claimed that the North Koreans illegally entered China for economic reasons and that they have been treated in accordance with relevant international law, national law and humanitarianism. It has not elaborated on the legal grounds for its decision on the status of the North Korean escapee nor has it indicated whether it investigated individual situations to determine their status.

C Protocol on Cooperation in the Work of Maintaining National Security and Social Orders at Border Areas between China and North Korea

The Chinese government has reportedly relied on China-North Korean bilateral treaties to justify its repatriation of North Koreans. ${ }^{404}$ A number of articles on North Korean escapees mentioned bilateral agreements between China and North Korea, which require China to repatriate North Korean. However, there are several versions of the name and the time of conclusion of the agreements. For example, Brookings-Bern Project on Internal Displacement in 2010 mentioned a Mutual Cooperation Protocol for the Work of Maintaining National Security and Social Order in the Border Areas signed in 1986 between China and North Korea, and that art 4 of this

\footnotetext{
${ }^{402}$ People's Republic of China 3rd and 4rth Combined Report on the Implementation of the Convention on the Rights of the Child, CRC/C/CHN/3-4 (6 June 2012), at [187].

${ }^{403} \mathrm{CEDAW} / \mathrm{C} / \mathrm{CHN} / 7-8$, above $\mathrm{n} 346$, at [225].

${ }^{404}$ Margesson, Chanlett-Avery and Bruno, above n 59, at 11; Seymour, above n 89, at 4; HRW, above n 59 , at 29.
} 
protocol "allows for deportations by providing cooperation between China and North Korea in 'preventing the illegal border crossing of residents'., 405

A Human Rights Watch (HRW) report entitled "The Invisible Exodus: North Koreans in the People's Republic of China" and published in November 2002 mentioned "a secret agreement ... on the repatriation of illegal migrants and criminals" between China and North Korea signed in the early 1960s and "a protocol on security in the border area" concluded in August 1986, under which China claimed to be obliged to repatriate North Koreans to North Korea. ${ }^{406}$ The HRW report said that contents of neither the secret agreement nor the 1986 protocol had not been published.

Seymour in his UNHCR-commissioned article "China: Background Paper on the Situation of North Koreans in China" in 2005 said that in "the context of China's famine of the early 1960s, the two countries in 1961 drew up a still-secret treaty" which created obligations for China to return North Koreans who have entered China illegally. ${ }^{407} \mathrm{He}$ further mentioned "an alleged 1986 protocol between the two countries' security ministries", which is entitled Mutual Cooperation Protocol for the Work of Maintaining National Security and Social Order in the Border Areas and provides that both sides were to "co-operate on the on the work of preventing the illegal border crossing of residents" and that any criminal should "necessarily be handed over to the other side". Seymour noted that the text of the 1986 protocol, which was obtained in December 2002 by Rescue the North Korean People Urgent Action Network (a Japanese NGO) and published on a Japanese website in English, could not be authenticated but "does not seem implausible". ${ }^{408}$ According to the published English translation, art 4 of this protocol stipulates: ${ }^{409}$

(1) Both sides shall mutually cooperate on the work of preventing the illegal border crossing of residents.

In the case of crossing the border without possession of a legal certificate or without passing through screening agencies or the passage places stated on the possessed certificate, [the individual] shall be treated as an illegal border crosser ... .

(2) Regarding individuals who illegally cross the border, depending on the situation a name-list or relevant materials should be turned over to the other side .... .

A report prepared by the United States Congressional Research Service dated 26 September 2007 also mentioned "a bilateral 1986 repatriation agreement" between China and North Korea, which gives China the obligation "to return all border crossers". ${ }^{410}$ Jendrzejczyk said in an

\footnotetext{
${ }^{405}$ Brookings-Bern Project on Internal Displacement, above $\mathrm{n} 61$, in note 10.

${ }^{406} \mathrm{HRW}$, above $\mathrm{n} 59$, at 11 and 29.

${ }^{407}$ Seymour, above $\mathrm{n} 89$, at 4 and 13 .

${ }^{408}$ Seymour, above n 89 , at 13 .

${ }^{409}$ Chan and Schloenhardt, above n 61, at 224.

${ }^{410}$ Margesson, Chanlett-Avery and Bruno, above n 59, at 11.
} 
article published in November 2002 that Chinese authorities repatriated North Koreans "under the terms of a secret 1986 agreement between Beijing and Pyongyang." 411 Cutler mentioned a treaty between China and North Korea which permitted North Koreans to legally enter China temporarily. ${ }^{412}$ According to Cutler, the agreement became effective in late 2001 but the text of the agreement was unavailable.

Among the Chinese-North Korean bilateral treaties I found in major Chinese legal databases, there is a "The Ministry of Public Security of the People's Republic China and The Ministry of National Security of the Democratic People's Republic of Korea Protocol on Cooperation in the Work of Maintaining National Security and Social Orders at Border Areas" signed on 8 July 1998. ${ }^{413}$ The bilateral protocol entered into force on 28 August in the same year. Article 4 of this protocol provides for the cooperation in prevention of illegal border crossing as follows:

The two Parties cooperate with each other in the work of preventing illegal exit and entry.

(1) Persons, who do not have valid documents or do not exit or enter through the designated passage and inspection authorities in accordance with the documents they are holding, are regarded as illegal border crossers.

However, persons (including people suffering from mental disorder) from one Party of this Protocol, who enter the territory of the other party of this protocol for reasons of different kinds of disasters and force majeure, are not be regarded as illegal border crossers.

Persons holding border area exit-entry pass (for Chinese, it is "PRC Chinese-North Korea border area exit-entry pass" type B, for North Koreans, it is "DPRK border area residents border crossing pass"), who enter the non-border area upon approval by public security authorities and exit-entry control authorities, are not regarded as illegal border crossers.

(2) Regarding illegal border crossers, depending on the situation, a name-list and relevant materials should be handed over to the other Party. However, regarding any person who commits a criminal offence after crossing the border, one Party may handle the person according to its law and inform the other Party of the situation.

This protocol resembles the agreement on border area affairs that mentioned in several articles except that it was concluded in 1998 instead of 1986. According to art 4(2) this protocol, depending on the situation, China is required to hand over the name list of illegal border crossers and relevant materials to North Korea, however, the protocol does not explicitly require China to repatriate illegal border crossers. Instead, China is required to hand over criminal suspects who enter China after committing criminal offences in North Korea (art 5(1)).

\footnotetext{
${ }^{411}$ Michael Jendrzejczyk "A Refugee Travesty: From Eating Rats in North Korea to Sex Abuse in China" The New York Times (online ed, New York, 19 November 2002).

${ }^{412}$ Cara Cutler "China's Provision of Temporary Visas to North Koreans - Reconsidering the Protection of migrants in the 21st Century" (2006) Stanford Journal on East Asia Affairs, winter 2006, 63 at 67.

413 The Chinese version of the bilateral protocol is available at Global Law $<$ http://policy.mofcom.gov.cn/PDFView?id=TYCX000076\&libcode=gjty $>$ (accessed 6 April 2014). The original text of the protocol is in Chinese and Korean.
} 
It is worth noting that art 4(1) of the protocol stipulates that persons crossing the border without valid documents for reason of disasters and force majeure are not considered illegal border crossers. The 1999 USCRI World Refugee Survey has noted that China had "generally tolerat[ed] the presence of thousands of North Korean "illegal immigrants" for years prior to $1999 .{ }^{414}$ As mentioned above, the crisis of North Korean escapees in China is generally believed to have started in the mid-1990s due to famine in North Korea. This means that many of the early arrivals were tolerated by Chinese authorities, despite the 1992 Notice which emphasised repatriation of illegal immigrants, including North Koreans, in the early 1990s. In light of this, it is not impossible that the Chinese government considered the famine in North Korea as a kind of disaster, and hence tolerated their stay in China. ${ }^{415}$ In the late 1990 s, the famine in North Korea was no longer as severe as in the mid-1990s; more importantly, the North Korean escapees in China began to attract international attention. These factors probably prompted China's crackdown on North Korean escapees in 1999.

Additionally, art 3(3) allows residents of the Chinese-North Korean border area to cross the border without a passport or visa. Border residents are eligible for a special border area exitentry pass, which would enable them to visit their relatives living in border areas in the other country and is valid for one month. However, the protocol stipulates that applications to visit relatives across the border should be strictly assessed; approval will be granted to those who have immediate relatives on the other side of the border; those visiting non-immediate relatives are required to provide an invitation letter (art 3(3)).

The Chinese government, however, has never identified the title or time of conclusion of the bilateral treaty or treaties. Nor has it mentioned a treaty allowing temporary entry by North Koreans. When asked to verify the existence a bilateral repatriation treaty between China and North Korea at MFA press conferences on 7 January 2003 and 23 January 2007, MFA spokesmen essentially ignored the question, neither confirming nor denying. ${ }^{416}$

It should be emphasised that even if China does have obligations to repatriate North Korean illegal border crossers under any bilateral agreement with North Korea, those obligations by no means override China's obligations under the 1951 Refugee Convention and the Protocol.

\section{Protocol on Chinese-Myanmar Border Management and Cooperation}

China and Myanmar concluded a Protocol on Chinese-Myanmar Border Management and Cooperation on 25 March 1997. The Protocol entered into force on 29 September 1997. Similar

\footnotetext{
414 "In January 1999, after years of generally tolerating the presence of thousands of North Korean 'illegal immigrants', China began expelling large numbers of North Koreans." USCRI "U.S. Committee for Refugees World Refugee Survey 1999 - China, (including Hong Kong and Tibet)" (1999) USCRI $<$ http://www.refworld.org/docid/3ae6a8a61f.html > (accessed 27 April 2014).

${ }^{415}$ In the 1960s, many Chinese escaped to North Korea when famine hit China, and China requested North Korea to repatriate them. This perhaps contributes to China's repatriation of the North Korean escapees in China.

${ }^{416}$ MFA Press Conference, Beijing, 7 January 2003, 23 January 2007.
} 
to the Chinese-North Korean bilateral protocol, the Chinese-Myanmar bilateral protocol contains an article on turning over illegal border crossers: ${ }^{417}$

regarding persons who cross the border illegally and persons who violate the public order at the border, both parties should investigate and take appropriate measures, and hand them over to their country of nationality. One party must provide the other party the name, photo, and detailed address of such persons before handing over. After the other party verifies and agrees, the handover time and place may be negotiated and decided; relevant evidence shall also be handed to the other party.

The Chinese-Myanmar allows border residents from one party to enter designated border areas of the other party with a border exit-entry pass (churujing tongxingzheng), exempting them from a normal visa (art 20(2)). ${ }^{418}$ The bilateral protocol defines border residents as "permanent residents in the border area of one party" (art 1) and border areas as "Chinese county (city) or Myanmar township listed in appendix I of the protocol" (art 1). The designated border areas are as in Chart 7.

Compared to the arrangement for border passes under the Chinese-North Korean bilateral protocol, the arrangement under the Chinese-Myanmar protocol not only allows border residents to apply for a border pass regardless of whether they have relatives in the other country, but also encourages border residents to get involved in many activities in addition to visiting relatives (art 20(1)). This suggests that Chinese authorities are more comfortable with people movements between China and Myanmar than those between China and North Korea.

As mentioned in chapter I, Chinese authorities referred to the displaced Kokangs and displaced Kachins as border residents and refused to recognise them as refugees. In the Kokang Incident, the majority of the displaced Kokangs came from Laukkai (number 11 in Chart 7), the capital of Kokang Region. Most of them were likely to have a border pass which enablesd them to cross into China. During the Kachin influx, many of the displaced Kachins fled to China's Yingjiang County (number 7 in Chart 7) and Longchuan County (number 8 in Chart 7), which are open to border residents from Myanmar. As will be discussed in chapter VI, a proportion of the displaced Kachins were from highland villages and did not hold a border pass; that probably explained why not all displaced Kachins were let in by Chinese border authorities initially. In light of the above, it is highly likely that the Chinese-Myanmar bilateral protocol is the legal ground for China's tolerance of the entry and stay of the displaced Kokangs and Kachins.

\footnotetext{
${ }^{417}$ Article 22(2).

${ }^{418}$ Normally, Myanmar nationals need a visa to enter China. Myanmar nationals holding a border pass, which functions as a travel document for border residents, do not need a Chinese visa or a formal Myanmar passport to enter China, but will need to have their border pass stamped by the Chinese authorities. Interview conducted by the author (12 April 2013).
} 
Chart 7 Designated Border Towns on Chinese-Myanmar Border under Appendix I of the Chinese-Myanmar Bilateral Protocol

\begin{tabular}{|c|c|c|}
\hline & China & Myanmar \\
\hline 1 & Chayu & Nagmung \\
\hline 2 & Gongshan & Khawbude \\
\hline 3 & Fugong & Sawlaw \\
\hline 4 & Lushui & Chipwi \\
\hline 5 & Tengchong & Waingmaw \\
\hline 6 & Longling & Momauk \\
\hline 7 & Yingjiang & Mansi \\
\hline 8 & Longchuan & Namhkam \\
\hline 9 & Wanding & Muse \\
\hline 10 & Ruili & Konkyan \\
\hline 11 & Luxi & Laukkai \\
\hline 12 & Zhenkang & Kunlong \\
\hline 13 & Gengma & Hopang \\
\hline 14 & Cangyuan & Mongmao \\
\hline 15 & Lancang & Pangwaum \\
\hline 16 & Ximeng & Mampan \\
\hline 17 & Menglian & Pangyang \\
\hline 18 & Menghai & Mongyang \\
\hline 19 & Jinghong & Kengtung \\
\hline 20 & Mengla & Mongyaung \\
\hline
\end{tabular}

The Chinese-Myanmar bilateral protocol does not state how long a border pass holder can stay after crossing the border. It should be mentioned that the arrangement of border passes for residents in border areas is a practice established between China and Myanmar long before the 1997 bilateral protocol between China and Myanmar. The Yunnan provincial government issued the Yunnan Province Administrative Rules for Entry-Exit of Foreign Border Residents in Chinese-Myanmar Border Areas (Yunnan Entry-Exit Rules) in 1990, which allows border residents from Myanmar to stay in border areas in Yunnan for up to two years, subject to the approval of the border exit-entry administration department of local public security authorities at county or city level. ${ }^{419}$ China and Myanmar also hold frequent meetings to update and discuss the implementation of this agreement. ${ }^{420}$

\footnotetext{
${ }^{419}$ Border residents staying in Yunnan for employment, study, business or medical treatment can apply for temporary residence permit at the border exit-entry department of the local public security authorities at county or
} 


\section{E Protocol on the Repatriation of Lao Refugees between China and Laos}

During the Indochinese refugee influx in the late 1970s and early 1980s, Lao refugees escaped to China. In addition, China offered resettlement to about 2,500 Lao refugees from refugee camps in Thailand. ${ }^{421}$ At the end of 1990, the Lao government informed the Chinese government of its desire for the repatriation of the Lao refugees in China. ${ }^{422}$ By that time, the Chinese-Lao relations and situations in Laos had improved. Persecution of ethnic Chinese no longer existed in Laos. About 3,700 Lao refugees in China also expressed their willingness to return to Laos. ${ }^{423}$

On 10 April 1991, China signed a bilateral agreement on the repatriation of the Lao refugees with the Lao government. According to this agreement, China agrees to repatriate Lao refugees who are willing to return to Laos; Laos agrees to receive these refugees and be responsible for settling them. ${ }^{424}$ In July 1991, China, Laos and UNHCR signed a memorandum on the same matter. The memorandum further specifies the respective responsibilities of the Chinese and the Lao governments and states that UNHCR will provide technical support and will sponsor part of the repatriation. The text of neither the bilateral agreement nor the memorandum has been published.

The task of repatriating Lao refugees was carried out by the provincial government of Yunnan province, which hosted the largest number of Lao refugees in China. The Yunnan provincial government set up a team headed by a deputy governor of the province to oversee the repatriation. ${ }^{425}$ By October 1994, 2,919 refugees had been repatriated, 46 percent more than the originally planned 2,000, and the Chinese government spent more than two million Chinese Yuan on the project. ${ }^{426}$ By 1997, about 3,550 Lao refugees had returned to Laos. ${ }^{427}$

\section{Refugee Law and Procedures in Macau and Hong Kong}

As stated above, Macau and Hong Kong have autonomous legislative and executive system and independent judicial power. Given the close political, economic and cultural links between Hong Kong and Macau and China, refugee law and practice in Hong Kong and Macau may be taken into consideration by Chinese authorities when establishing China's refugee law. China has extended the application of the Convention and Protocol to Macau, but has not extended the application of these instruments to Hong Kong.

city level (art 15). Valid period of temporary residence permits is between three months to one year, and can be extended twice, six months per each extension (art 18).

420 “ $<$ zhongmian bainjing guanli hezuo xieding $>$ di shierlun sijuji huiwu zaimian juxing $\left[\right.$ The $12^{\text {th }}$ Department and Bureau Level Meeting on the Implementation of the China-Myanmar Protocol on Border Management and Cooperation Held in Myanmar]" $\quad(25 \quad$ February $\quad 2014)$ MFA $<$ http://www.fmprc.gov.cn/mfa_chn/wjb_602314/zzjg_602420/t1131797.shtml> (accessed 7 April 2014).

${ }^{421}$ Feith, above $\mathrm{n} 38$.

${ }^{422}$ Liang, above n 32, at 303.

${ }^{423}$ UNHCR, above $\mathrm{n} 41$.

${ }^{424}$ Liang, above $n$ 32, at 303.

${ }^{425}$ Defu Li (Deputy Director of Yunnan Civil Affair Department) "kaizhan qianfan nanmin gongzuo de chubu tihui [Preliminary Reflection on Works of Repatriating Refugees]" (1994) 10 zhongguo minzheng (Chinese Civil Affairs) 26 at 27.

${ }^{426} \mathrm{Li}$, above $\mathrm{n} 425$, at 26.

${ }^{427}$ Liang, above n 32, at 306. 
Macau adopted Law No.1/2004, establishing a Legal Framework on the Recognition and Loss of Refugee Status. Under art 3, the Legal Framework defines a refugee as a person who qualifies as a refugee according to the Convention and Protocol and a person who falls under the competence of the Office of UNHCR according to art 6 and art 7 of the UNHCR Statute. ${ }^{428}$ A commission was set up by the Legal Framework to conduct RSD (arts $5 \& 6$ ).

Macau's refugee definition is practically as generous as UNHCR's definition of a refugee. Despite Macau's generous refugee definition, the number of applications for refugee status and refugee recognition rate has been low in Macau. As of mid-2013, there were no refugees and only 6 asylum seekers residing in Macau. ${ }^{429}$ From 2002 to early September 2011, only 15 requests for refugee status were submitted, of which 10 were denied and one was cancelled. ${ }^{430}$ Macau is a case that illustrates the point that adoption of a refugee definition, even if a generous one, does not necessarily attract more asylum seekers.

Hong Kong, which is about three times the size of Macau, had 94 refugees and 1,332 asylum seekers as at mid-2013. ${ }^{431}$ Although, the Convention and Protocol have not been extended to Hong Kong, UNHCR maintains a Sub-Office in Hong Kong. Prior to 3 March 2014, a parallel screening mechanism existed in Hong Kong. On the one hand, the UNHCR Sub-Office in Hong Kong was allowed to process individual application for refugee status; on the other hand, Hong Kong authorities considered non-refoulement claims based on art 3 of the Convention against Torture. ${ }^{432}$ On 3 March 2014, the Government of Hong Kong commenced operation of a unified screening mechanism to determine claims for non-refoulement protection on applicable grounds including risk of "persecution with reference to the non-refoulement principle under art 33 of the Convention"; ${ }^{433}$ at the same time, UNHCR ceased to process asylum claims. ${ }^{434}$

Time will tell how Hong Kong authorities define the risk of persecution under the unified screening mechanism. It is worth mentioning that Hong Kong authorities have stressed their firm policy of not determining the refugee status of, or granting asylum to, anyone. ${ }^{435}$ If a person's non-refoulement claim on grounds of persecution risk is substantiated under the unified

\footnotetext{
428 Official Chinese and Portuguese version of the Legal Framework is available at $<$ http://images.io.gov.mo/bo/i/2004/08/lei-1-2004.pdf> (accessed 7 April 2014).

429 "Macau (Special Administrative Region of China) Statistical Snapshot" (2014) UNHCR $<$ www.unhcr.org/pages/49e488436.html> (accessed 7 April 2014).

430 "No Refugee Status Ever Granted" (29 September 2014) Macau Daily Times $<$ http://www.macaudailytimes.com.mo/macau/30055-no-refugee-status-ever-granted.html> (accessed 7 April 2014).

431 UNHCR "Hong Kong (Special Administrative Region of China) Statistical Snapshot" (2014) $<\mathrm{http}: / /$ www.unhcr.org/cgi-bin/texis/vtx/page?page=49e488026\#> (accessed 7 April 2014).

${ }^{432}$ Kelley Loper "Human Rights, Non-Refoulement and the Protection of Refugees in Hong Kong" (2010) 22(3) International Journal of Refugee Law 404 at 412.

${ }^{433}$ Hong Kong Government "Commencement of Unified Screening Mechanism for Claims for Non-Refoulement Protection" (7 February 2014), available at Hong Kong Government Information Web $<$ http://www.info.gov.hk/gia/general/201402/07/P201402070307.htm> (accessed 16 April 2014).

434 UNHCR "Unified Screening Mechanism" (26 March 2014) UNHCR $<$ http://www.unhcr.org.hk/unhcr/en/news_and_updates/news_list/news_details.html?id=1115> (accessed 16 April 2014).

${ }^{435}$ Government of Hong Kong, above n 433.
} 
screening mechanism, the person would be referred to UNHCR for recognition of refugee status. $^{436}$

\section{A National Refugee Law at the Horizon?}

The absence of any legal framework dealing with refugee matters may be attributed to several factors. First, except for the Indochinese refugees, China had little experience of receiving refugees or asylum seekers before the mid-1990s. Motivation to develop relevant legal framework was probably lacking.

Second, like many former Soviet Bloc countries, China makes little legal distinction between refugees, tourists, and immigrants. Former Soviet Bloc nations had typically resisted the concept of refugees throughout the Cold War; it was common practice among these countries not to classify refugees as a category of population movement. ${ }^{437}$

Third, having strictly restricted the entry of and the residence in China of all aliens, China had few provisions encouraging or favouring inflows of foreigners in general, let alone provisions pertaining to refugees. China's restrictive immigration policy was initially motivated by the Chinese Communist Party's anti-foreigner policies. According to the 1948 Instruction of the Central Committee of Chinese Communist Party on the Policy Regarding the Treatment of Aliens in China: ${ }^{438}$

The Chinese government and army will have a friendly policy towards aliens in China. However, more watchfulness and measures are needed to prevent certain aliens from spying on, destroying and interfering with Chinese internal affairs.

Hostility towards Communist China by many countries further consolidated China's restrictive immigration policy. The Regulations on the Administration of Entry, Exit, Transit, Residence and Travel of Aliens in China (1964) which codified previously practised control policies on aliens, provided in art 8 that: ${ }^{439}$

Aliens must enter into, exit from and transit in China by means of appointed exit ports, transportation vehicles and routes. Aliens entering into China shall go only to the destination noted in the visa. Aliens must directly enter into, exit from and transit in China and must not stop off unless permitted.

\footnotetext{
${ }^{436}$ Government of Hong Kong, above n 433.

${ }^{437}$ Maria Redei “Hungary” in Solon Ardittis (ed) The Politics of East-West Migration (St Martin's Press, New York, 1994) 89.

${ }^{438}$ Liu, above $n 15$, at 5 .

${ }^{439}$ At 7.
} 
China's reluctance to grant legal status to asylum seekers could also be understood in light of the general resistance to international refugee law by Asian countries. As mentioned above in chapter II, the majority of Asian countries are not parties to the Convention and Protocol; of those that have acceded to the Convention and/or the Protocol, most have not enacted domestic legislation to implement these instruments; there have been no regional refugee arrangements specifically tailored for Asia. As noted by UNHCR, a lack of understanding of refugee issues generally hinders the promotion of a favourable refugee protection environment in East Asia. ${ }^{440}$ This is probably true of China. Thirty years after China's accession to the Convention and Protocol, the term "refugee" still sounds unfamiliar and remote to most Chinese people. For the government, the refugee issue remains a sensitive one.

Since the 1990s, the Chinese government (specifically the MFA, the MPS and the Ministry of Civil Affairs (MCA)) have been working on drafting a national refugee law with assistance of UNHCR. ${ }^{441}$ Several symposiums were held jointly by the Chinese government and UNHCR between 2004 and 2007 to discuss issues such as state sovereignty and refugee protection, refugee status determination mechanism and procedure, treatment of refugees, cooperation between the Chinese government and the UNHCR and relevant experience of other AsianPacific countries. In a symposium in September 2012 jointly organised by UNHCR and the MFA, an international refugee law expert from New Zealand was invited to present the national refugee legislation of New Zealand as a case study. ${ }^{442}$

According to UNHCR, a draft refugee regulation with inputs from all relevant ministries was submitted to the State Council for deliberation in 2008 , but the draft was not adopted. ${ }^{443}$ In a report submitted to the United Nations Committee on the Elimination of Discrimination against Women (UNCEDW) in early 2012, China stated that Rules for Identification and Administration of Refugees, which provide for refugee definition, authorities in charge of refugee affairs, refugee status determination, temporary settlement and repatriation of refugees and loss and removal of refugee status, had been drafted. ${ }^{444}$ It also claimed to be making efforts to finalise the legislation work as soon as possible, but no time line was provided. ${ }^{445}$

If China started work on drafting national refugee legislation in the 1990s, about 20 years have been spent on the draft, yet China still has few legal provisions relating to refugees, let alone a refugee law. Why is the progress slow? Liu, a Chinese immigration law expert, has pointed out three reasons for the delay of China's refugee law. First, China has not developed a culturally diverse and tolerant society. Second, there are political considerations involving neighbouring

\footnotetext{
${ }^{440}$ UNHCR, above n 290.

${ }^{441} \mathrm{CEDAW} / \mathrm{C} / \mathrm{CHN} / 7-8$, above $\mathrm{n} 346$, at [225].

${ }^{442}$ UNHCR Regional Representation for China and Mongolia, above $\mathrm{n} 48$, at 2.

${ }^{443}$ UNHCR, above $\mathrm{n} 366$, at 2.

${ }^{444} \mathrm{CEDAW} / \mathrm{C} / \mathrm{CHN} / 7-8$, above n 346, at [225],

${ }^{445} \mathrm{CEDAW} / \mathrm{C} / \mathrm{CHN} / 7-8$, above n 346, at [225].
} 
countries. Third, there are concerns of attracting more refugees. ${ }^{446}$ These factors make China reluctant to promptly enact national refugee legislation or establish a national RSD mechanism.

\section{Conclusion}

The Chinese constitutions since 1949 have a consistent history of recognising the basic human right to seek asylum. Article 32 of the 1982 Constitution and art 46 of the Exit-Entry Law are the legal basis for China's recognition of refugees and their protection at the national law level.

However, Chinese law in general contains very few provisions which distinguish refugees from other migrants, and there is a gap between the criteria for asylum contained in art 32 of the 1982 Chinese Constitution and the criteria for refugee status contained in the Convention Refugee Definition. As the provisions of the Convention and Protocol have not been incorporated into Chinese law, the Chinese legal system cannot provide effective implementation of the provisions of the Convention and Protocol. As a consequence, China has relied mainly on bilateral agreements to handle repatriation as well as admission of refugees and other displaced foreigners who arrived as part of large-scale inflows.

China has clearly demonstrated a growing interest in handling RSD in a more formalised framework. Once the national refugee regulation being drafted is passed, it will have profound and positive impact on refugee status determination and refugee protection in China.

${ }^{446}$ Liu, above n 355. 


\section{Chapter IV China's Refugee Policy and Practice}

Governments have the power, whatever their legal obligations, to turn a blind eye to violations of the rights of refugees.

- Gil Loescher ${ }^{447}$

In the absence of a legal refugee definition in domestic Chinese law, it may be useful to look at China's refugee policy and practice. Officially the Chinese government has published few, if any, policy documents regarding refugee definition, RSD or the treatment of refugees or other displaced foreigners in China. Information about China's refugee policy can be found mainly in Chinese delegates' statements at UN meetings, records of MFA press conferences, China's State reports to international organisations, high ranking Chinese officials' speeches at international conferences, and articles written by government officials in academic journals. China's refugee policy is also reflected in China's practice in dealing with refugees and other displaced foreigners. In particular, its differing treatment of the Indochinese refugees, the North Korean escapees, the displaced Kachins, and the displaced Kokangs illustrates how China defines a refugee. In turn, China's experience with these groups also feeds the development of its refugee policy in time. This chapter focuses on exploring why China treated them this or that way.

\section{The Beginning of China's Refugee Policy: the Indochinese Refugee Crisis and Its Impact}

\section{A The Crisis and China's Response}

China probably began to pay attention to refugee issues and the international refugee protection regime after the influx of Indochinese refugees in 1978. Prior to that time, the Chinese government probably knew very little about the international refugee protection regime. An article in a periodical with links to the MCA revealed China's ignorance of the international refugee protection regime upon the arrival of the Indochinese refugees: ${ }^{448}$

China was caught completely unprepared by the Indochinese refugees, everything had to be learned from scratch, what is a refugee, why establish refugee camps, what obligations do we have, what rights do we enjoy, how to apply for international assistance, refugee affairs officials gathered relevant information little by little ....

\footnotetext{
${ }^{447}$ Loescher, above n 120 , at 138 .

448 Jing Zhang "Zhongguo weishenme bushe nanminying [Why China Did Not Establish Refugee Camps]" Zhongguo shehui daokan [China Society] (China, May 2002) at 58, emphasis added.
} 
On 4 August 1979, a working meeting on reception and resettlement of Indochinese refugees (the 1979 Meeting) was convened in Beijing; it was presided by then Chairman of China, Li Xiannian, and Vice Minister of the State Council, Chen Muhua, and attended by officials from Ministries and government departments involved in receiving and resettling the Indochinese refugees. ${ }^{449}$ The 1979 Meeting laid down four principles for the Indochinese refugee reception and settlement: (1) from the standpoint of political implication and humanity, the reception and resettlement work should be handled with care and responsibility; (2) political education for the refugees should be strengthened; (3) the refugees' living conditions should be improved gradually; and (4) publicity and reporting of relevant reception and resettlement work should be enhanced. ${ }^{450}$ Under principle 4, the 1979 Meeting required that all Vietnamese, Laos and Cambodian who were expelled by Vietnamese authorities and escaped to China should be referred to as refugees without exception.

The first principle laid down by the 1979 Meeting suggests that China had both political and humanitarian reasons for accepting and settling the Indochinese refugees. That China intended to educate them politically and to improve their living conditions gradually demonstrates its intention to assimilate the refugees and host them on a long-term basis, if not permanently.

Most importantly, the 1979 Meeting officially announced China's recognition of the Indochinese as refugees in China. This recognition was, and has remained a policy decision. Chinese authorities have never published any official document regarding the recognition of the refugee status of the Indochinese in China. No individual screening of the Indochinese was conducted before or after the 1979 Meeting. ${ }^{451}$

It is notable that the recognition of the Indochinese as refugees came under the last principle laid down by the 1979 Meeting, which emphasised enhancing publicity and reporting of relevant reception and settlement work. This probably suggests that recognition of the Indochinese as refugees was not considered as very important compared to other matters relating to the Indochinese. It is also notable that the favourable treatment of the Indochinese refugees started long before the 1979 Meeting. As mentioned in chapter I, the Indochinese had been generously assisted since April 1978 when the exodus from Vietnam into China first started, and the settlement process had begun shortly after April 1978. By June 1979, about 235,000 Indochinese refugees had arrived; hundreds of thousands of them had been transferred from the border area to settle on OCFs by the time of the 1979 meeting. ${ }^{452}$

In hindsight, China was exceptionally generous with the Indochinese. First, China was among the very few Asian countries to allow local settlement of the Indochinese refugees. ${ }^{453}$ Second,

\footnotetext{
${ }^{449}$ Liang, above n 32, at 273.

${ }^{450}$ Liang, above $\mathrm{n} 32$, at 274.

${ }^{451}$ Muntarbhorn, above n 51, at 60.

${ }^{452}$ UN General Assembly Meeting on Refugees and Displaced Persons in South-East Asia, convened by the Secretary-General of the United Nations at Geneva, on 20 and 21 July 1979, and subsequent developments: Report of the Secretary-General, A/34/627 (1979).

${ }^{453} \mathrm{~W}$ Courtland Robinson Terms of Refuge: the Indochinese Exodus \& the International Response (Zed Books, London, 1998), at 282.
} 
the Indochinese refugees remain the only group that the Chinese government has officially recognised as refugees since its establishment in 1949. As mentioned in chapter I, China has not identified any person or group as refugees after the Indochinese refugees. ${ }^{454}$ Additionally, China was not a party to the Convention until 1982 and the country was still poor at that time. Nevertheless, it provided timely protection and local settlement to the Indochinese refugees.

An important and well recognised reason for China's receptivity to the Indochinese refugees is that the majority of the refugees were ethnic Chinese. ${ }^{455}$ Ethnic, linguistic and cultural links between incoming refugees and the native population are known as strong causes for the receptivity of the receiving country to incoming refugees, particularly in the Third World. ${ }^{456}$ Because of geographic proximity, racial affinities between the Chinese and the Vietnamese, and the pervasive influence of Chinese culture in Vietnam, many of the Chinese in Vietnam were born in China and maintained close ties with China. ${ }^{457}$ Most refugees speak one or more Chinese languages, such as Cantonese, Mandarin Chinese, and Hakka. ${ }^{458}$ Their living habits, moral outlook and religious practices were similar to that of the native Chinese. Many had relatives in China. These ethnic, linguistic and cultural links between the Indochinese refugees in China and the native Chinese no doubt contributed significantly to China's willingness to accept and settle the Indochinese refugees.

However, the legal grounds for China's acceptance of the Indochinese refugees have rarely been examined. As mentioned above, art 32(2) of the 1982 Constitution and art 15 of the 1985 Alien Entry-Exit Law have been frequently referred to as the legal ground for China's protection of refugees. We shall bear in mind that most of the Indochinese arrived and settled before the 1982 Constitution and the 1985 Alien Entry-Exit Law existed. On the one hand, China was not a party to the Convention and Protocol, and the Chinese government had little knowledge of the international law and practice of refugee protection when the majority of the Indochinese refugees were accepted. On the other hand, the Indochinese refugees in China were generally persecuted for being ethnic Chinese, ${ }^{459}$ and hence hardly fit into art 29 of the 1975 Constitution or art 59 of the 1978 Constitution, both of which provided that "The People's Republic of China grants the right of residence to any foreigner who is persecuted because of her support for justice, participation in revolutionary movements or conduct of scientific work." On what legal ground did China accept and settle the Indochinese?

\footnotetext{
${ }^{454}$ China generally allows UNHCR Beijing Office to process individual applications for refugee status, but has not been substantially involved in RSD procedures administrated by UNHCR. It acknowledges the status of UNHCR refugees. See Sec III.A of chs I and V.

${ }^{455}$ Ninety eight per cent of the Indochinese refugees who fled to China between 1979 and 1982 were ethnic Chinese. Song, above $\mathrm{n}$ 34. Recognition of ethnic link as China's main motivation for taking the Indochinese, eg Muntarbhorn, above n 51, at 65; Lam, above n 36, at 386.

${ }^{456}$ Loescher, above $\mathrm{n} 120$, at 25 .

${ }^{457}$ Chang, above $\mathrm{n} 353$, at 2.

${ }^{458}$ Xiaorong Han "Exiled to the Ancestral Land: the Resettlement, Stratification and Assimilation of the Refugees from Vietnam in China" (2013) 10 International Journal of Asian Studies 25 at 27.

${ }^{459}$ Liang, above n 32, at 270.
} 
To answer this question, it may be useful to look at China's initial response to the exodus of refugees from Vietnam. This has rarely been examined in the small volume of the existing literature that looks at the Indochinese refugees in China after the early $1980 \mathrm{~s} .{ }^{460}$

As mentioned in Chapter I, the majority of the Indochinese refugees in China were ethnic Chinese fleeing from Vietnam. The exodus of the ethnic Chinese from Vietnam, as perceived by Godley, was related to the nationality question. ${ }^{461}$ The same probably can be said of China's readiness to accept and settle the refugees from Vietnam. When the exodus from Vietnam to China began to gain momentum in April 1978, China promptly charged Vietnam with persecuting Chinese nationals. It contended that the crisis all started with the forced naturalization Vietnam had imposed upon the Chinese and that in doing so Vietnam had departed from the principle of voluntary naturalization jointly agreed upon by the two countries in 1955 to reduce dual nationality. ${ }^{462}$ Vietnam, nevertheless, claimed that there were no "persecuted Chinese" or "Chinese nationals", only "Hoa people" or "Vietnamese of Chinese origin", and counter-charged China with manipulating the Hoa people to flee. ${ }^{463}$ In the months to come, China and Vietnam argued whether the displaced ethnic Chinese were victimised Chinese nationals as China claimed or Hoa people of Vietnamese citizenship as Vietnam claimed, exchanging charges and counter charges.

The problem of dual nationality of and competing claims over the ethnic Chinese in Southeast Asia had been a long-standing phenomenon. Since the late $19^{\text {th }}$ century, the Chinese communities abroad have been seen as a valuable source of financial and political support by the Chinese government. Accompanying the Chinese government's financial and political interest in the Chinese abroad was the pursuing of jus sanguinis by the Chinese government and the resulting issue of dual nationality. Both the Qing Imperial government and the Nationalist government of China had passed laws to claim jurisdiction over overseas Chinese and prohibited naturalisation without government consent; this was contrary to the doctrine of jus soli adopted by a number of Southeast Asian countries. ${ }^{464}$ Following the post-war decolonisation of Southeast Asia and the communist victory in China in 1949, nationalism rose alongside with fear for communist pervasion in Southeast Asia, and the large number of Chinese dual nationals in the

\footnotetext{
${ }^{460}$ Refugees who came from Vietnam counted for more than 98 per cent of the Indochinese refugees who fled to China. Chaozhi Peng "laowo nanmin daqianfan (Repatriation of the Laotian Refugees)" shidai fengcai [Modern Elegance] (China, October 1994) at 40.

${ }^{461}$ Godley, above n 448, at 35. For background of the exodus, see ch I of this thesis. See also Chang, above n 353 , chs II and III.

${ }^{462}$ Spokesman of the Overseas Chinese Affairs Office of the State Council "Statement on Viet Nam's Expulsion of Chinese Residents" (2 June 1978) 22 Beijing Review 14, at 16.

${ }_{463}$ Godley, above n 448, at 50; Chang, above n 353, at 39.

${ }^{464}$ For discussions on dual nationality of the Chinese in Southeast Asia, see eg Tung-Pi Chen "The Nationality Law of the People's Republic of China and the Overseas Chinese in Hong Kong, Macao and Southeast Asia" (1984) 5 New York Law School Journal of International and Comparative Law 281; Leo Suryadinata "China's Citizenship Law and the Chinese in Southeast Asia" and Charles A Coppel "The Indonesian Chinese: "Foreign Orientals", Netherlands Subjects, and Indonesian Citizens in M Barry Hooker (ed) Law and the Chinese in Southeast Asia (Institute of Southeast Asian Studies, 2002, Singapore).
} 
region had become a source of constant tension and controversy between China and Southeast Asian countries. ${ }^{465}$

A consequence of these controversies and tension was the repatriation of the ethnic Chinese in Southeast Asian countries. In the early 1950s, Malaya deported about 19,000 Malayan Chinese who were deemed communists; they were well received and settled by China. ${ }^{466}$ China established ad hoc committees at national and local level to oversee and facilitate the reception and settlement of these Malayan Chinese; OCFs were established for the first time to settle them. In 1959 as well as in 1966 and 1967, China sent multiple ships to Indonesia to bring home about 136,000 Chinese expelled by Indonesia; ${ }^{467}$ more OCFs were opened to absorb these returners. Ships were also sent to India in 1963 to pick up the Chinese marginalised by the Indian government; ad hoc offices for reception and resettlement of Indian Chinese were established; most returners were again settled on OCFs. ${ }^{468}$ China regarded all of these ethnic Chinese returning from overseas as Chinese nationals. ${ }^{469}$

Prior to the refugee influx, the assimilation of the Chinese in Vietnam was still in process. China and North Vietnam agreed in 1955 that Chinese nationals residing in North Vietnam would be administered by Vietnam, ${ }^{470}$ and that on the condition that they enjoy the same rights with the Vietnamese, they might step by step adopt Vietnamese nationality after being given sustained and patient persuasion and ideological education. ${ }^{471}$ The 1955 agreement did not spell out the time needed for the process of naturalisation or whether the Chinese administered by Vietnam should be considered as Chinese nationals or fully-fledged Vietnamese citizens during the interim period. Neither did the 1955 agreement specify whether the Chinese in South Vietnam should be subject to the same principle of integration after the unification of North and South Vietnam. In 1961, China and Vietnam signed another agreement which allowed Vietnam to issue travel documents to the Chinese returning to China for short visits, but Vietnam was still not authorised to issue regular passports to them. ${ }^{472}$

As early as in June 1977, in his talks with Vietnamese Premier Pham Van Dong, Chinese Vice Premier Li Xiannian expressed China's concern of Vietnam's policy of forced naturalisation of and discrimination against the Chinese in Vietnam for the first time. ${ }^{473}$ The reasons for China's

\footnotetext{
${ }^{465}$ Chen, above $\mathrm{n} 464$, at 289.

${ }^{466}$ Shichao Deng and Lichang Huang "zhongguo yuenan guiguo nanqiao de anzhi yu shengchan shenghuo xianzhuang tanxi: yi Guangdong yangcun huaqiao ganjuchang weili [Analysis on Reception of Overseas Chinese in Difficulty Returning from Vietnam and Their Present Work and Life Conditions: a Case Study of Guangdong Yang Village Overseas Chinese Mandarin Farm]" (2010) 58 Ritsumeikan University Journal of Economics 87 at 88.

${ }^{467}$ Deng and Huang, above n 466, at 88.

${ }^{468}$ Guangxi Zhuang Autonomous Region Local Chronicle Commission "guangxi tongzhi: qiaowuzhi [Guangxi Chronicle: Overseas Chinese Affairs Chronicle]" (online ed, Guangxi People's Press, 1996), section 5 chapter 1 part 2, available at Guangxi Local Information Net $<$ http://www.gxdqw.com/bin/mse.exe?seachword=\&K=a\&A=55\&run=12> (accessed 23 April 2014).

${ }^{469}$ Guangxi Zhuang Autonomous Region Local Chronicle Commission, above $\mathrm{n} 468$, section 5 chapter 1 part 2.

${ }^{470}$ Paomin Chang "The Sino-Vietnamese Dispute over the Ethnic Chinese" (1982) 90 The China Quarterly 195 at 196.

${ }^{471}$ Renmin Ribao commentator "Lies Cannot Cover up Facts" (16 June 1978) 24 Beijing Review 17 at 17

${ }^{472}$ Chang, above n 470, at 197.

${ }^{473}$ Chang, above n 470, at 203.
} 
expressly raising the issue were multiple. Firstly, there had been small but continuous flows of ethnic Chinese returning from Vietnam since April 1977 due to discrimination against the Chinese in Vietnam. ${ }^{474}$ Secondly, the Sino-Vietnamese relation was rapidly deteriorating due to territorial disputes and Kampuchea. Thirdly, China's interest in ethnic Chinese abroad was reviving. Just months before the exodus, in February 1978, then Chairman of China, Hua Guofeng, emphasised that China opposed any attempt to compel the overseas Chinese to change their citizenship and was duty-bound to protect those who decided to keep their Chinese citizenship. $^{475}$

It should also be mentioned that from the 1940s through the 1970s, the ethnic Chinese living in Vietnam had frequently crossed into Guangxi, China from Vietnam due to wars in Vietnam. ${ }^{476}$ These people were all treated as returning Chinese nationals by the Chinese government and were locally settled.

In light of the above, it is, perhaps, not surprising that when the ethnic Chinese from Vietnam poured into China in April 1978, China immediately accused Vietnam of persecuting Chinese nationals, and took exactly the same measures to receive them as it did to receive the ethnic Chinese from Malaya, Indonesia and India in the 1950s and 1960s. At the national level, China established a Committee for the Reception and Settlement of Returned Overseas Chinese (jiedai anzhi guiqiao weiyuanhui). ${ }^{477}$ At the provincial level, Guangxi formed a Leading Group for Reception and Settlement of Overseas Chinese in Distress (jiedai anzhi nanqiao lingdao xiaozu) in May 1978; ${ }^{478}$ Guangdong also established the Guangdong Province Committee for Reception and Settlement of Returning Overseas Chinese (Guangdong sheng jiedai anzhi guiguo huaqiao weiyuanhui) in May 1978. ${ }^{479}$ On 15 June 1978, China sent two ships to Ho Chi Minh City and

\footnotetext{
${ }^{474}$ Beijing Review, 18 August, 1977, as cited in Chang, above n 470, at 203.

${ }^{475}$ Chang, above n 353 , at 26.

${ }^{476}$ From 1940 to 1945 , several thousand ethnic Chinese arrived in Guangxi from Vietnam to flee Japanese bombing. In 1947, upon the return of the French to Vietnam, more than 2,000 Chinese crossed into Guangxi, and the Kuomingtang government sent many planes to Hanoi to repatriate more Chinese; large numbers of Chinese fled to Guangxi as the French bombed northern Vietnam in the following two years. The flow continued well into the 1950s. In 1967, 25 Chinese sought asylum in Guangxi after the Chinese community in Vietnam protested and struke against the Vietnamese authorities which had forced the Chinese to learn Vietnamese and to close down Chinese schools. During the Vietnam War, many Chinese again entered Guangxi for refuge between 1968 and 1972 . Before and after the bombing of Haiphong in North Vietnam, more than 1,000 Chinese arrived each day at the tiny town of Fangcheng in Guangxi. Guangxi Zhuang Autonomous Region Local Chronicle Commission, above n 468, section 3 chapter 1 part 2.

${ }^{477}$ The Committee was later replaced by the Leaders' Group for Reception and Settlement for Indochinese refugees established in 1979. Jianfeng Wei "xinzhongguo guiqiao xuesheng jiaoyu wenti shuyao [Summary of the Education of Returning Overseas Chinese Students in New China]" (25 April 2011) Guangdong Overseas Chinese Web (Guangdong Province People's Government Office for Overseas Chinese affairs) $<$ http://gocn.southen.com/qwyj/201104/t20110425_155249.htm> (accessed 28 April 2014).

${ }^{478}$ The leaders' group was renamed as the Leaders' Group for Reception and Settlement of Indochinese Refugees in February 1979. Guangxi Zhuang Autonomous Region Local Chronicle Commission, above n 468, section 3 chapter 1 part 2. The Chinese term "nanqiao" is not defined by Chinese law. It can be translated as "overseas Chinese in distress". The term was used to refer to the overseas Chinese expelled by Malaya, Indonesia and India.

${ }^{479}$ The committee was transformed into the Guangdong Province Office of the Leaders' Group for Reception and Settlement of Indochinese refugees in October 1979. Xuezhi Li "anzhi guiqiao, nanqiao [Settling Returned Overseas Chinese and Overseas Chinese in Distress]" Guangdong Provincial Information Web $<$ http://210.76.65.23/books/301/10702.html > (accessed 28 April 2014).
} 
Haiphong to bring home "victimised Chinese nationals persecuted by the Vietnamese authorities", ${ }^{480}$ exactly as it did for the expelled ethnic Chinese in Indonesia and India in the 1950s and 1960s. Alas, this time the ships returned to China empty at the end of July in 1978 after Vietnam refused to let them dock. ${ }^{481}$ By the time the empty ships returned to China, more than 160,000 persons had fled to China from Vietnam, and tens of thousands had been promptly transported from temporary border shelters to settle on OCFs.

As a 2002 article published in a periodical under the auspices of the MCA pointed out, China had little idea of the concept of a refugee and international refugee protection regime at the beginning of the exodus, and thus treated them as huaqiao (Chinese nationals who had settled overseas) based on the fact that most of them were ethnic Chinese. ${ }^{482}$ Since they were considered Chinese nationals, the ethnic Chinese arriving from Vietnam had the right to stay in China, and it is only natural that they were settled on the OCFs, known as huaqiao nongchang in Chinese, which had been established for the exclusive purpose of accommodating returning overseas Chinese nationals, such as the expelled Chinese from Malaya, Indonesian and India.

This leads to another question: why did China later decide to recognise the ethnic Chinese from Vietnam as refugees? Despite China's desire to keep its promise to take care of huaqiao, a practical matter was that its absorptive capacity could by no means match the scale and the pace of the influx. Since May 1978, China had repeatedly demanded, in vain, that Vietnam act to stop the exodus in many rounds of bilateral negotiations with Vietnam. On 12 July 1978, China announced the closure of the Chinese-Vietnamese land border, probably hoping to slow the flow. ${ }^{483}$ But the influx continued. China then withdrew its technical aid to Vietnam and ordered the closure of three Vietnamese consulates in Nanning, Guangzhou, and Kunming. ${ }^{484}$ In February 1979, the month-long Sino-Vietnam war broke out. By then, Beijing probably had exhausted its diplomatic and economic measures to make Vietnam act on stopping the exodus. Perhaps it was not a coincidence that in Guangxi the Leading Group for Reception and Settlement of Overseas Chinese in Distress was renamed as the Leading Group for Reception and Settlement of Indochinese Refugees in February 1979, ${ }^{485}$ and that in Yunnan Province, the ethnic Chinese from Vietnam who came during after the war were called refugees (nanmin), while those who arrived before the Sino-Vietnam war were called overseas Chinese in distress

\footnotetext{
${ }^{480}$ Godley, above n 448, at 50 .

${ }^{481}$ Godley, above n 448, at 52 .

${ }^{482}$ Zhang, above $\mathrm{n} 448$, at 62 . The periodical is published by China Social News Publication Group under the MCA. According to the People's Republic of China Law on Protection of the Rights and Interest of Returned Overseas Chinese and Their Family Members (1990, amended in 2000), huaqiao is defined as Chinese nationals who have settled abroad (art 2); guiqiao (a short term for guiduo huaqiao) is defined as huaqiao who have returned to China for permanent residency. The English version of the law is available at Peking University Law Information Web $<$ en.pkulaw.cn>.

${ }^{483}$ Godley, above n 448, at 51; Jay Mathews "Refugees Worry South China: Thousands of Refugees from Vietnam Produce Uneasiness in South China" The Washington Post (Washington, 16 July 1978) at A18.

484 "China Compelled to Terminate Economic and Technical Aid to Viet Nam" (14 July 1978) 28 Beijing Review 27 at 27.

${ }^{485}$ Guangxi Zhuang Autonomous Region Local Chronicle Commission, above n 468, sec 5 ch 1 pt 2.
} 
(nanqiao). ${ }^{486}$ China probably began to realise that Vietnam could not care less about the fate of the ethnic Chinese and was determined to get rid of them anyway. By recognising the ethnic Chinese from Vietnam as refugees, China, who had suffered public humiliation as the professed protector of the overseas Chinese and had borne, and would continue to bear, social and economic burdens resulting from the influx, could at least seize the moral high ground in her bitter battle with Vietnam, because China was no longer just taking in its own citizens who were unwanted by Vietnam, but was generously offering asylum and humanitarian assistance to the homeless refugees. This perhaps explains why the recognition of the refugee status of the Indochinese at the 1979 Meeting came under a principle emphasising the promotion of publicity and reporting of the reception and settlement of the Indochinese refugees in China.

Additionally, having been unable to bring Vietnam to face the issue of ethnic Chinese at the negotiation table, China decided to promote international pressure on Vietnam from late June 1979. ${ }^{487}$ In July 1979, a Chinese delegation led by China's then Deputy Foreign Minister was sent to the Meeting on Refugees and Displaced Persons in South-East Asia convened by the Secretary-General of the UN at Geneva on 21 and 22 July. Less than three weeks later, China held the 1979 meeting in Beijing and officially announced its recognition of the status of the Indochinese as refugees.

Apart from the ethnic and historical connections between the Indochinese refugees and China, other factors probably have also contributed to China's receptivity towards the refugees. ${ }^{488}$ First, Sino-Vietnamese relations had been rapidly deteriorating since 1975. The Indochinese refugee crisis was only one of the multiple conflicts between China and Vietnam that eventually led to the Sino-Vietnamese war in February $1979 .{ }^{489}$ The ideological rift between China and Vietnam and the worsening Sino-Vietnamese relation, in combination with the pro-China sentiment openly demonstrated by the Chinese communities in Vietnam, ${ }^{490}$ were important reasons for Vietnam's hostility and maltreatment of the Chinese in Vietnam. China, which was not unaware of the pro-China sentiment of the ethnic Chinese in Vietnam given her close ties with them, might have felt somewhat obliged to come to the help of the refugees. ${ }^{491}$

Second, having just finally gained its seat at the UN in 1971 after many years of diplomatic battle with Taiwan, ended the extreme leftist Cultural Revolution in 1976, and began its opendoor policy and economic and political reform in late 1978, China was eager to improve its

\footnotetext{
${ }^{486}$ Ding, $\mathrm{Xu}$ and Liang, above $\mathrm{n} 79$.

${ }^{487}$ Chang, above n 353, at 58.

${ }^{488}$ Vietnam exercised significant influence on Laos which was a client state of Vietnam and occupied Kampuchea in January 1979. Of the about 270,000 Indochinese refugees Chinese accepted, about 4,000 were Laotian and Cambodian and they were mostly resettled from Thai refugee camps between 1980 and 1981. See Peng, above $n$ 460, at 41; Feith, above n 38, Appendix; Liang, above n 32, at 306.

${ }^{489}$ See Chang, above n 353.

${ }^{490}$ Chang, above n 353, at 62.

${ }^{491}$ Vietnam charged China for spreading rumours and enticing the Chinese to leave for China. Chang's opinion was that China was not likely to have the political appeal and the organisational resources to start a massive exodus from Vietnam to China but might have contributed to the exodus by alerting the Chinese of Vietnam's hostility resulting from the worsening Sino-Vietnamese relations and by speaking enthusiastically on behalf of the Chinese. Chang, above $\mathrm{n} 353$, at 34 .
} 
international image and be accepted in international society. By extending humanitarian assistance to the refugees expelled by Vietnam, and, as instructed in the fourth principle laid down by the 1979 Meeting, publicising and promoting its humanitarian work for the Indochinese refugees, China did enhance its international image and win praise from the outside world for what it had done for the Indochinese refugees.

China's good faith and humanitarian considerations in the course of receiving the Indochinese refugees should not be denied or underestimated. Precisely as China reminded the international community at a UN meeting in 1986, "despite its stringent economy and heavy population burden", it had taken 280,000 Indochinese refugees for local integration. ${ }^{492}$

\section{B The Impact of the Crisis}

The Indochinese refugee crisis was a milestone for China in terms of its legal, policy and institutional development relating to incoming refugees and asylum seekers. The crisis leaves rich and mixed legacies to China. First, the acceptance of more than a quarter million Indochinese refugees provided China the first hands-on experience of handling a massive influx of refugees. Unlike the return of the ethnic Chinese from Malaya, Indonesia and India, who were brought home by Chinese vessels, the arrival of the Indochinese refugees (except those brought back from Thai camps) was unplanned. China drew on its past experience with the ethnic Chinese expelled by other Asian countries and mobilised the local communities to provide relatively smooth reception and local settlement for the Indochinese refugees. It also gained experience in repatriation operations from the repatriation of Lao and Cambodian refugees in the 1990s. China won well-deserved recognition and applause for its assistance to the Indochinese refugees from the international community. In 2006, António Guterres, then United Nations High Commissioner for Refugees, praised the local integration of Indochinese refugees in China as "one of the most successful integration programs (of refugees) in the world". 493

In retrospect, although China's treatment of the Indochinese refugees was in line with the standards set by the Convention and Protocol, the majority of the Indochinese refugees were accepted and settled as returning overseas Chinese nationals. As mentioned above, China had little, if any, knowledge of the international refugee protection regime when it accepted and settled the majority of the Indochinese refugees. Rather than intentionally following the Convention and Protocol, China probably happened to provide the majority of the Indochinese, who were considered as returning overseas nationals at the time of their acceptance and settlement, the same protection afforded by the Convention and Protocol for refugees.

Second, the Indochinese refugee crisis introduced China to the contemporary international refugee regime, led to the establishment of a UNHCR office in Beijing in 1979 and paved the way for China's accession to the Convention and Protocol in 1982. China soon actively

\footnotetext{
${ }^{492}$ UNGA Summary Record of the 407th meeting on 9 October 1986, Executive Committee of the High Commissioner's Programme, Thirty-Seventh Session, A/AC.96/SR.407 (16 October 1986), at 6, as cited in Davies, above $\mathrm{n} 289$, at 184 .

${ }^{493}$ Song, above $\mathrm{n} 34$.
} 
participated in international discussions on the Indochinese refugees, and its refugee policy gradually took its initial shape during this time. For example, in 1979, China, along with the United States, Australia and Japan, defended Southeast Asian countries' demand for significant financial and resettlement assistance, arguing that the international community's assistance was essential. ${ }^{494}$ In 1984, China argued that the main problem with the lengthy Indochinese refugee crisis was that "none of the root causes of outflows had been eliminated". 495 Since UNHCR did not address pre-refugee issues, China's proposal was considered quite radical at that time. However, this proposal quickly gained support from other countries. China still repeatedly emphasises burden sharing and addressing the root causes when it addresses the international refugee problem today.

Third, an institutional network, ie the ORSIRs at national and provincial levels, for handling refugee matters was established. The ORSIRs, like the ad hoc committees established for the reception and settlement of returning overseas Chinese from Southeast Asia in the 1950s and 1960s, were established on an ad hoc basis. However, China later decided to keep them as permanent offices. These offices are still functioning nowadays, coordinating both domestic and international aid projects for the Indochinese refugee community. Though the ORSIRs have not been involved in non-Indochinese refugee matters, they would be a useful institutional resource, which China could make use of when China forms its national refugee status determination procedures.

Not all of the Indochinese refugee crisis' impacts on China are positive. The international responses to the Indochinese refugee crisis provided China a practical lesson on the art of handling refugee problems. China's Southeast Asian neighbours were a particularly negative example in treating refugees. Thailand, Malaysia, Indonesia and Singapore all systematically pushed refugees away from their borders at various points in the history of the exodus. ${ }^{496}$ All Southeast Asian countries, including the Philippines, which was the only Southeast Asian State party to the Convention and Protocol during the time of the Indochinese refugee crisis, consistently refused to allow Indochinese refugees to settle locally. ${ }^{497}$ By breaching international law and delivering ultimatums to the international community, Southeast Asian states successfully negotiated higher offers of resettlement places, received higher financial contribution, and were expected to do no more than offer temporary asylum. ${ }^{498}$ Though the international society condemned Southeast Asian countries' refugee policy and practice, more

\footnotetext{
${ }^{494}$ UNGA Summary Record of the 305th Meeting on 9th October 1979, Executive Committee of the High Commissioner's Programme, Thirtieth Session, A/AC.96/SR.305 (11 October 1979), at 9, as cited in Davies, above n 289, at 122 .

${ }^{495}$ Davies, above n 289, at 177.

${ }^{496}$ Robinson, above n 453, at 282.

${ }^{497}$ The Philippines, which acceded to the Convention in 1981, generally refused to offer local settlement for the refugees. It made only one exception under the strong advocacy of the Catholic Church to allow about 2,500 Vietnamese living in Palawan, who refused to return to Vietnam, to settle locally, however, the Philippino government suggested the offer of local settlement was an exceptional gesture to close the chapter on the Indochinese and was not necessarily permanent. Robinson, above n 453, at 282.

${ }^{498}$ Davies, above n 289, at 122.
} 
often than not they could do little but to provide financial assistance and resettlement quotas requested by Southeast Asian countries. Southeast Asian States learned that "hard hearts could drive hard bargains". ${ }^{499}$ It is likely that China has noticed and learned this from its Southeast Asian neighbours.

Somehow the puzzle of the nationality of the Indochinese refugees remains today. The deputy director of Guangxi provincial ORSIR, who also held the position of the head of the Settlement Department of Guangxi Overseas Chinese Affairs, mentioned in his 2006 article that: ${ }^{500}$

In the international context, we refer to this group [the Indochinese] as refugees, because this group fits in the UN definition of refugees. ... In the domestic context, we refer to them as nanqiao, they are huaqiao who returned to the motherland because of persecution.

More often than not, the Indochinese are known by the local communities as overseas Chinese who returned to China instead of as refugees, and it is not uncommon that they are referred to as nanqiao or guiqiao by government officials and State media as well as in academic articles. ${ }^{501}$ The Indochinese refugee whom I interviewed also referred to herself as huaqiao most of the time during the interview (see chapter VI). In Guangxi, a number of Indochinese refugees were even allowed to hold government positions. ${ }^{502}$ In Yunnan, officially the local authorities refer to the Indochinese as a whole as refugees, but in reality those who arrived before the Sino-Vietnam War are still known as nanqiao and those who arrived during or after the war are known as refugees. ${ }^{503}$ The equivocality of the status of the Indochinese refugees suggests that the Indochinese refugee crisis may have never been dealt with by China as a "pure" refugee matter. Notably, in Yunnan Province those categorized as nanqiao are mainly settled on OCFs and have been given household registration and Chinese ID cards in a timely manner; those categorised as refugees are mainly accommodated in border villages and ordinary farms, and 10,700 of them, which is about 28 per cent of total Indochinese population in Yunnan, had not been able to obtain Chinese ID cards or have household registration as recently as 2009 despite their repeated requests. ${ }^{504}$ This perhaps helps explain why China's generosity towards the Indochinese Chinese has not been shown again in its treatment of all other refugees and displaced foreigners in China.

\footnotetext{
${ }^{499}$ Davies, above n 289, at 122.

${ }^{500}$ Guohua Zeng "Guangxi nanqiao peixun gongzuo de lanshang xianzhuang he tiaozhan [Status Quo of and Challenges for Trainings of Nanqiao in Guangxi]" (2006) 2 bagui qiaokan [Overseas Chinese Journals of Bagui] 47 at 47.

${ }^{501}$ See eg Deng and Huang, above n 466; Han, above n 458, at 38, Huaquan Chen "cong nanmin dao guomin: chongxin Shenshi yuenan guiqiao jianit tequ 30nian [From Refugees to Nationals: Rethinking the Participation of Returned Overseas Chinese from Vietnamese in Developing the Special Zone in the Past 30 Years]" (20 August 2012) China National Radio <http://zh.cnr.cn/2100zhfw/syyw/201208/t20120820_510637382_1.shtml> (accessed 28 April 2014).

${ }^{502}$ Guangxi Zhuang Autonomous Region Local Chronicle Commission, above n 468, chapter I.4.

${ }^{503}$ Ding, Xu and Liang, above $\mathrm{n} 79$.

504 "duiwai hezuo chu 2009 nian gongzuo zongjie he 2010 nian gongzuo jihua [Office of External Cooperation 2009 Work Report and 2010 Work Plan]" (8 Mar 2010) Yunnan Civil Affairs
} 


\section{Developments: From North Korean Influx to Kokang Incident to Kachin Influx}

\section{A Wang's Four Point Proposal in 2001}

After the Indochinese refugee crisis and before the arrival of the North Koreans in the mid-1990s, China received few refugees and asylum seekers. During this period, China's attention to refugee matters was directed mainly toward the repatriation of the Lao and Cambodian refugees. Though China often prides itself on its outstanding work in settling the Indochinese refugees locally, it has never concealed its desire to repatriate them. Through cooperation with the Lao and Cambodian governments and coordination by UNHCR, China repatriated about 3,550 Lao refugees and 30 Cambodian refugees between 1991 and $1997 .{ }^{505}$ It has also sought to repatriate the Vietnamese refugees. A Chinese representative stated in 1996 at an UNHCR meeting that: ${ }^{506}$

China regarded voluntary repatriation as the most appropriate solution to the refugee problem, ... With the conclusion of the Comprehensive Plan of Action in South-East Asia and the resulting solution to the problem of Vietnamese refugees in Southeast Asia, the repatriation of the Vietnamese refugees in China had become a matter of urgency.

Negotiations were held between China and Vietnam regarding the repatriation, but according to Chinese media, Vietnam was unwilling to involve UNHCR ${ }^{507}$ Hence the repatriation of the Vietnamese refugees has never started.

In the post-Indochinese refugee crisis era, a notable change of the situation in China in the broader background is the increasing mobility of people across the border. In the 1980s, as China relaxed the restriction on foreigners' entry to China and its economic conditions began to improve, the number of aliens entering China increased greatly. China obviously had realised the need to curb illegal immigration as early as in 1992, when the MPS issued the 1992 Notice to require provincial public security authorities to take action against illegal entry and illegal stay of aliens. ${ }^{508}$ The notice highlighted the increasing problem of illegal Vietnamese and North Korean immigrants, who entered and stayed in China, and of Pakistanis, Iranians and Afghans overstaying in China after their Chinese visa expired. It also noted illegal immigrants from Myanmar.

China probably did not expect that the illegal North Korean border crossers would turn into a humanitarian crisis in less than 10 years' time and that displaced ethnic minorities from

\footnotetext{
$<$ http://yunnan.mca.gov.cn/article/ztzl/mzgzh/cszj/201003/20100300060711.shtml> (accessed 10 March 2014). The number of Indochinese refugees in Yunnan was 38, 009 in 2005. Xueju Li (ed) Minzheng 30 nian (Civil Affair in the Past 30 Years) (China Society Press, Beijing, 2008), at 344, cited from Liang, above n 32, at 281.

${ }^{505}$ Liang, above n 32, at 306.

${ }^{506}$ Executive Committee of the Programme of the United Nations High Commissioner for Refugees Forty-seventh Session Summary Record of the 509th Meeting, A/AC.96/SR.509 (1997).

507 “2012 Sun Yat-Sun University Model UN Meeting Background Document”, above n 62.

${ }^{508}$ GONGTONGZI[1992]NO39, above n 394.
} 
Myanmar would also challenge its asylum policy two decades later. From another angle, perhaps because China had noticed the flow of unauthorised border crossers from North Korea and Myanmar over the years and had perceived and had treated them as illegal economic migrants for years, China is less likely to be convinced that they are refugees.

In December 2001, China's then Vice Foreign Minister Wang Guangya proposed the following four points to address the refugee problem at a ministerial meeting of State parties to the Convention: (1) "to safeguard world peace, [and] promote common development" in order to prevent the emergence of refugees at the root; (2) "to effectively uphold the authority of the Convention and the existing regime for international protection and actively explore new ways and means for resolving the refugee problem"; (3) "to adhere to the principles of "international solidarity' and 'burden sharing' and carry out international cooperation effectively"; (4) "to draw a clear line between the refugee issue and others, preventing the abuse of the protection regime and asylum policies as prescribed in the Convention". 509

The first and the third points proposed by Wang were basically reiterating the principles of eliminating the root causes and burden sharing which China had adopted since the Indochinese refugee crisis. The second point may be seen as a general expression of China's support for the existing protection regime, but it also suggested China's preference of exploring new solutions within the existing protection regime rather than changing the regime.

The fourth point reflected China's conservative position toward the definition of a refugee in 2001. Under this point, Wang warned of negative impacts of "unrestrained expansion of the asylum procedures of the Convention" on the international refugee protection regime and urged UNHCR to "work strictly within its mandate". Though this statement was originally made to address the refugee problem in a global context, it is most likely that China's call for drawing a clear line between refugee issues and others was related to the North Korean escapees in China. On 26 June 2001, seven North Koreans sought asylum in UNHCR Beijing Office; it was the first time North Korean escapees reached UNHCR Beijing Office. ${ }^{510}$ Chinese authorities subsequently agreed in an arrangement with UNHCR and South Korea to allow these seven North Koreans to go to South Korea "on humanitarian grounds". 511

B Controversial Repatriation of the North Korean Escapees

$1 \quad$ China's Policy on the North Korean Escapees

As mentioned in previous chapters, while scholars and human rights groups have argued North Korean escapees are refugees, China has argued that they are illegal economic migrants, not

\footnotetext{
${ }^{509}$ Guangya Wang, Vice Foreign Minister of China "Statement at the Ministerial Meeting of States Parties to the 1951 Convention Relating to the Status of Refugees" (Geneva, 12 December 2001), available at Permanent Mission of the People's Republic of China to the UN Office at Geneva and Other International Organizations in Switzerland (Chinese Permanent Mission to Geneva) <http://www.china-un.ch/eng/rqrd/thsm/t85105.htm> (accessed 19 April 2014).

510 UNHCR "China: UNHCR Helping North Koreans" (26 June 2001) UNHCR $<$ http://www.unhcr.org/3b3889530.html $>$ (accessed 20 April 2014).

511 UNHCR "Seven North Korean asylum seekers arrive in Seoul" (30 June 2001) UNHCR $<$ http://www.unhcr.org/3b4049cb1.html $>$ (accessed 20 April 2014).
} 
refugees, describing criticisms on its repatriation of the North Koreans as "not acceptable". 512 China's argument is straight-forward and simple: the North Korean escapees enter China mainly for economic reasons and there are no sufficient grounds to establish their status as refugees; therefore they are illegal border crossers, not refugees. ${ }^{513}$ However, Chinese officials routinely declined to comment or offer any explanation of China's treatment of the North Korean escapees or whether China determined their status on group or individual basis, merely claiming that China has handled them in accordance with domestic law, international law, and the spirit of humanity. ${ }^{514}$

On 3 June 2013, MFA spokesman Hong Lei said at a news briefing that China "always opposes making it an international and political issue or an issue of refugees. ${ }^{, 515}$ Hong's comment summarised well China's policy towards the North Korean escapees.

First, China desires to avoid international attention and criticism regarding its treatment of North Korean escapees. Sceats and Breslin noted that China's approach to human rights matters had been "low-key, watchful and above all defensive". ${ }^{516}$ China's handling of North Korean escapees and relevant international criticism reflects that approach. An example is China's response to high-profile cases of North Korean escapees seeking asylum in foreign establishments in China and the immediate impact of these cases on North Korean escapees in China. The on-going North Korean escapee crisis is generally traced back to the mid-1990s, when large numbers of North Koreans entered China due to the famine in North Korea. China had tightened security on the Sino-North Korean border since then. However, up to 1999 it had not launched systematic crackdowns. ${ }^{517}$ In the early 2000 s, humanitarian workers and NGOs assisted North Korean escapees in breaking into the UNHCR Beijing Office and a series of foreign embassies and international schools in China, bringing the North Korean escapees in China under the international spotlight. ${ }^{518}$

\footnotetext{
512 "Press Conference by Minister of Foreign Affairs Li Zhaoxing during the Second Session of the 10th NPC" (6 March 2004) MFA <http://www.fmprc.gov.cn/eng/wjb/wjbz/2467/t71616.htm > (accessed 19 September 2012).

${ }^{513}$ Eg MFA press conference, Beijing, 16 January 2003, 25 December 2007, 22 January 2008, 22 February 2012, 28 February 2012.

${ }^{514}$ Eg MFA press conference, Beijing, 19 Mar 2002, 16 January 2003, 17 February 2004, 11 October 2005, 7 December 2006, 23 January 2007, 22 February 2008, 22 February 2012.

${ }_{515}$ Terril Yue Jones "China Warns U.N. against 'Irresponsible Remarks' on North Koreans" (3 June 2013) Reuter $<$ http://www.reuters.com/article/2013/06/03/us-korea-north-china-idUSBRE95209W20130603> (accessed 23 April 2014).

${ }^{516}$ Sonya Sceats and Shaun Breslin "China and the International Human Rights System" (October 2012) Chatham House

$<$ http://www.chathamhouse.org/sites/default/files/public/Research/International\%20Law/r1012_sceatsbreslin.pdf $>$ (accessed 28 April 2014) at 2.

${ }^{517}$ A 1999 USCRI report noted that "In January 1999, after years of generally tolerating the presence of thousands of North Korean 'illegal immigrants', China began expelling large numbers of North Koreans". USCRI, above n 414.

${ }^{518}$ See eg "Japan-China spat over North Koreans" (9 May 2002) BBC <http://news.bbc.co.uk/2/hi/asiapacific/1976702.stm> (accessed 20 April 2014); "Refugees Storm Beijing Embassy" (29 September 2004) BBC $<$ http://news.bbc.co.uk/2/hi/asia-pacific/3699786.stm> (accessed 20 April 2014); Elisabeth Rosenthal "North Koreans Get Asylum at Beijing Embassies" The New York Times (online ed, New York, 27 April 2002).
} 
Although North Koreans who made their way into the UNHCR Beijing Office, diplomatic compounds or even foreign schools were eventually allowed to leave China (mostly for South Korea via a third country), ${ }^{519}$ China emphasised repeatedly that those cases were dealt with on an ad hoc and case-by-case basis and that China never recognised them as refugees. As a result of these consulate asylum incidents, China quickly tightened the security around UNHCR and foreign embassies, making it more difficult for North Korean escapees to enter; a crackdown in border areas intensified. ${ }^{520}$ Few North Koreans even attempted to seek asylum in foreign establishments in China after 2006. On the contrary, it was noted in 2007 that China tolerated the inflows of North Korean escapees and the activities of foreign NGOs so long as such activities were carried out quietly. ${ }^{521}$ Humanitarian workers helping North Korean escapees also noticed that public attention could result in greater danger and intensified militarization in the border areas North Korean escapees frequented. ${ }^{522}$

Second, China has insisted on the economic nature of the illegal flow cross the Sino-North Korean border, and possibly follows this conclusion to address the problem in its own way. For example, China was reported to have been issuing 20,000 work visas to North Koreans amid a crackdown of illegal North Korean migrants in 2012. ${ }^{523}$ Analysts believed that China's motivation to issue work visas to North Koreans was to reduce illegal North Korean migrants and to introduce low-cost labour in Northeast China. ${ }^{524}$ Another source said that in 2013, China issued 93,000 work visas to North Korean citizens, 17 per cent up from the previous year. ${ }^{525}$

\section{Political and Security Consideration Underlying China's Policy on the North Korean Escapees}

China's resistance to recognising North Koreans as refugees may be primarily attributed to its fears of attracting more North Korean escapees and to North Korea's strategic location. ${ }^{526}$ Chinese officials and academics have expressed the view that if asylum is granted to one North Korean escapee today, thousands or millions could pour into China. At the very least, the influx per se could be a threat to the stability of China's border region. Given the pervasive fear of political instability amongst the political elite and the general public in China, ${ }^{527}$ the influx is anything but desirable to China. The potential of the exodus of North Koreans could be more devastating to China. Large scale departure of North Koreans could seriously shake the ruling of

\footnotetext{
${ }^{519519}$ See eg UNHCR, above n 511; HRW, above n 61, at 29.

${ }^{520}$ Seymour, above n 89 , at 15 .

${ }^{521}$ Margesson, Chanlett-Avery and Bruno, above n 59, at 11.

${ }^{522}$ Han, above $\mathrm{n} 89$, at 547.

523 "China Gives Work Visas for 20,000 N.Koreans” The Chosunilbo (online ed, Seoul, 28 May 2012).

524 "zhongguo nigei liangwan chaoxianren gongzuo qianzheng [China is to Issue Work Visa to 20,000 North Koreans]" (26 May $\quad$ 2012) BBC $<$ http://www.bbc.co.uk/zhongwen/simp/chinese_news/2012/05/120526_china_nkorea_workpermits.shtml > (accessed 25 April 2014).

${ }^{525}$ Oliver Hotham "Work Visas for North Koreans Going to China up 17.2\%" (21 January 2014) NK News $<$ http://www.nknews.org/2014/01/work-visas-for-north-koreans-going-to-china-up-17-2/> (accessed 8 April 2014).

${ }^{526}$ See eg Margesson, Chanlett-Avery and Bruno, above n 59, at 12; Seymour, above n 89, at 16.

${ }^{527}$ Katherine Morton "The Emergence of NGOs in China and Their Transnational Linkages: Implication for Domestic Reform” (2005) 59(4) Australian Journal of International Affairs 527.
} 
the North Korean regime and lead to the collapse of North Korea. The collapse of North Korea would not only add to the political instability in the East Asia region, but would also expose China directly to the large United States military force posted in South Korea.

Additionally, China's close relationship with North Korea is believed to affect China's policy towards the North Korean escapees. China is a formal ally of North Korea according to the SinoNorth Korean Treaty on Friendship and Mutual Assistance. ${ }^{528}$ Particularly, as mentioned in chapter III, China is obliged to hand over North Korean criminals to North Korea according to a bilateral agreement between the two countries. Since leaving North Korea without permission is a criminal offence according to North Korea criminal law, ${ }^{529}$ granting asylum to North Korean escapees would strain Sino-North Korea relations and consequentially weaken China's influence on North Korea's behaviour. Given North Korea's strategic location and its ability to destabilise the region through military provocation, China naturally would not want to antagonise North Korea. ${ }^{530}$

\section{The Contrast between the North Korean Escapees and the Indochinese Refugees}

There is obvious difference between the North Korean escapees and the Indochinese refugees in China in terms of the causes, the pace and the pattern of their exodus, their country of origin's relation with China, China's political and economic situations at the time of their arrival, and their ethnic, linguistic and cultural connection with the majority of China's population.

The situations of the North Korean escapees and the Indochinese refugees do resemble each other in one way. That is the movement of people is closely interlinked with and subordinated to the political and strategic interest, which somewhat pushed humanitarian issues to the background. ${ }^{531}$ For the Indochinese, it was China and Vietnam's disputes over territory and Kampuchea; for the North Korean escapees, it is China and North Korea's disagreement on North Korea's nuclear weapon and missile programme. It appears that the North Koreans escapees had been used as political currencies by state governments. In 2009, Beijing was reported to have temporarily suspended the repatriation of North Korean escapees after North Korea's launched a missile without prior notification to Beijing. ${ }^{532}$

The Importance of Meaningful Protection

As discussed in chapter II, the status of the North Korean escapees in China involves complex legal issues. It is clear, however, that the North Korean escapees in China are in need of international assistance and that it is a pressing issue for China and the international community.

\footnotetext{
${ }^{528}$ The treaty was established and entered into force on 10 September 1961.

${ }^{529}$ Democratic People's Republic of Korea, Criminal Code, art 117, cited from Seymour, above n 89, at 26.

${ }^{530}$ Margesson, Chanlett-Avery and Bruno, above n 59, at 12.

${ }^{531}$ Seymour, above $\mathrm{n} 89$, at 12; Chang, above n 353, at 54.

${ }^{532}$ Lan Lin "Beijing zanting qianfan chaoxian nanmin (Beijing Suspended Repatriation of North Korean Refugees)" (18 April 2012) Radio France International <http://www.chinese.rfi.fr/\%E4\%B8\%AD\%E5\%9B\%BD/20120418\%Е5\%8C \%97\%E4\%BA \%AC\%E6\%9A\%82\%E5\%81\%9C\%Е9\%81\%A3\%E8\%BF\%94\%E6\%9C\%9D\%Е9\%B2\% 9C\%E9\%9A\%BE\%E6\%B0\%91> (accessed 28 April 2014).
} 
Given the complex political and security implications of the issue, a viable solution for the North Korean escapees in China will not be realistic without political cooperation between and among countries concerned. This thesis calls for the Chinese government to start a constructive dialogue with UNHCR and other international stakeholders, including North Korea, on the issue of North Korean escapees in China as soon as possible. This thesis also calls for more scholarship and creative thinking on the situation of North Koreans crossing the Chinese-North Korean border and the means for creating meaningful protection space for the North Korean escapees in China.

\section{An Ambiguous Welcome: The Kokang Incident \\ $1 \quad$ China's Response to the Kokang Incident}

The points proposed by Wang Guangya in 2001 have been repeatedly expressed in one way or another by high-ranking Chinese officials. ${ }^{533}$ However, the call for a clear line between the refugee issue and other issues and adherence to the existing refugee protection regime rarely, if ever, reappeared. In statements made by high ranking Chinese officials in 2010 and 2011, China expressed its support for UNHCR to update and improve refugee protection mechanism in light of changes of international circumstances; it still called for prevention of abuse of international asylum system, but emphasised the balance between expanding the protection and preventing abuse of international asylum system and explicitly expressed that protection should be given to refugees and other displaced people. ${ }^{534}$ These changes can be regarded as positive signals from China that it is interested in dealing with the refugee issue in a less restrictive way, especially considering the fact that China had set up temporary camps to accommodate and feed thousands of ethnic Kokangs fleeing from Myanmar to China in 2009.

As mentioned in chapter I, during the so-called Kokang Incident in August 2009, approximately 37,000 displaced civilians flooded into Nansan town, Yunnan Province from Laukkai town of the Kokang Region in Myanmar in a few weeks as a result of the military standoff and clashes between the Myanmar government troops and Kokang's local army. The Chinese government quickly opened 7 camps to accommodate more than 10,000 displaced Kokangs and provided

\footnotetext{
${ }^{533}$ See Guangya Wang, Vice Foreign Minister of China "Remarks at the Opening Ceremony of The Third APC Mekong Sub-regional Meeting on Refugees, Displaced Persons and Migrants" (Beijing, 26 August 2002), available at Chinese Permanent Mission to Geneva <http://www.china-un.ch/eng/rqrd/xgwt/t85185.htm> (accessed 8 April 2014); Cheng Luo, Chinese Delegate to the UN "Statement at the Third Committee of the 64th Session of the UN General Assembly on Refugees" (New York, 3 November 2009), available at Chinese Permanent Mission to Geneva <http://www.china-un.org/eng/hyyfy/t624524.htm> (accessed 8 April 2014); "Dai Bingguo Meets UN High Commissioner for Refugees Guterres" (3 September 2010), MFA $<$ http://www.fmprc.gov.cn/chn/pds/gjhdq/gjhdqzz/lhg/xgxw/t737390.htm> (accessed 8 April 2014); Guixuan Zhang, Chinese Delegate to the UN "Statement at the Third Committee of the 67th Session of the UN General Assembly on Refugees" (New York, 7 November 2012), available at China Permanent Mission to Geneva <http://www.chinaun.org/eng/hyyfy/t987021.htm> (accessed 8 April 2014).

${ }^{534}$ Yafei He, Chinese Ambassador to UN, Statement on the 61st UNHCR Excom" (Geneva, 4 Oct 2010), available at Chinese Permanent Mission to Geneva <http://www.china-un.ch/eng/hom/t758725.htm> (accessed 8 April 2014); Yafei He, Chinese Ambassador to UN, Statement at the intergovernmental event at the ministerial-level of Member States of the United Nations to commemorate the 60th anniversary of the 1951 Convention relating to the Status of Refugees and the 50th anniversary of the 1961 Convention on the Reduction of Statelessness (Geneva, 9 December 2011), available at Chinese Permanent Mission to Geneva <http://www.china-un.ch/eng/hom/t885656.htm> (accessed 8 April 2014).
} 
them with food, blankets, drinking water, medicine and a small amount of daily allowance in cash. In addition to allowing civilians to take refuge in China, Chinese authorities also took in the remnants of the Kokang army, disarming them at the border and putting them in guarded camps. ${ }^{535}$ As the conflict in Kokang Region eased in early September 2009, the displaced Kokangs were voluntarily repatriated and the camps were removed.

The Kokang Incident was the first of its kind to receive wide publicity in China after the Indochinese influx. The Yunnan provincial government held a press conference to inform the public of the situation of the displaced Kokangs in Yunnan. ${ }^{536}$ Many mainstream Chinese media covered the incident. Government and semi-government organisations were mobilised to channel humanitarian assistance to the displaced Kokangs.

As to the status of the displaced Kokangs in China, the Chinese authorities acknowledged that the Kokangs came to China to escape military standoff and armed conflict in Kokang Region and consistently referred to them as "border residents", or in Chinese "bian min", from Myanmar. ${ }^{537}$ Despite actively and openly providing protection and assistance to the displaced Kokangs during the Kokang Incident, Chinese officials never publicly referred to the displaced Kokangs as "refugees". Notably, the Chinese authorities did not bother separating the ethnic Kokangs from Chinese nationals who were doing business in the Kokang Region when they provided the number of people fleeing the Kokang Region during the influx. The Chinese authorities only released the gross number of the incoming population which included both ethnic Kokang civilians fleeing into China and the returning Chinese citizens who were doing business in Kokang Region; Chinese citizens returning from Kokang Region were also referred to as "border residents". 538

\section{$2 \quad$ Possible Legal Grounds and Political Motivations}

A possible explanation for China's choice of word is that the Kokangs were admitted on the ground of 1997 China-Myanmar bilateral protocol on border management and cooperation. ${ }^{539}$ As mentioned in chapter III, art 20 of the protocol allows border residents of one Party to travel to designated border areas of the other Party through designated border towns with a border pass. Laukkai, the capital town of Kokang Region in Myanmar is a designated border town according to the protocol. As will be discussed in chapter VI, it is relatively easy for border residents from Myanmar to apply for a border pass at Myanmar immigration offices near the border and it is not uncommon for people living near the Chinese-Myanmar border to have a border pass. As will be discussed below, the Kokang Region is known for its close economic and cultural link to China. It is very likely that many ethnic Kokangs in the region had a border pass, which would enable them to enter China during the Kokang Incident. Even though the 1997 Sino-Myanmar protocol was not referred to by Chinese official in response to the influx, art 20 of the protocol probably

\footnotetext{
535 Thompson, above n 378, at 13; SCIO, above n 64.

${ }^{536}$ See Chapter I.

${ }^{537}$ MFA press conference, 1 Sep 2009; SCIO, above n 64.

${ }^{538}$ SCIO, above n 64.

${ }^{539}$ Concluded in Yangon, Myanmar on 25 Mar 1997, entered into force on 29 September 1997. See ch III.
} 
served as a main legal ground for the admission of the displaced Kokangs as China never challenged the legitimacy of the displaced Kokangs' entry into China.

The 1997 China-Myanmar protocol, as stated in its preamble, aims to provide convenience for cross-border human and goods movement, in contrast to the 1998 Sino-North Korean Protocol on Cooperation in the Work of Maintaining National Security and Social Orders at Border Areas, which focuses on safeguarding national security and social order and was based on the desire to "further develop the friendly relations between the public security department and security safeguarding department of the two countries" (preamble). The different focus of the two protocols perhaps suggests that China is more confident in handling people movements across the Chinese-Myanmar border than those on the Chinese-North Korean border. This confidence may have contributed to China's willingness to accommodate, at least temporarily, the displaced Kokangs in the border area where the Kokangs had been allowed to enter with little restriction anyway.

In fact, the Yunnan local authorities claimed that they provided humanitarian assistance to the displaced Kokangs from the standpoint of maintaining friendly relations between the two countries and stability in the border area. ${ }^{540}$ China has been a major supporter of the militarycontrolled government of Myanmar for decades, and Myanmar is usually described as a brother of China in domestic Chinese media. However, precisely because of the good relations between China and Myanmar, China's hospitality to the Kokangs seems unusual, especially considering that China not only took in displaced civilians but also soldiers of the Kokang army routed by the Myanmar government troops. ${ }^{541}$

\section{Common Characteristics between the Displaced Kokangs and the Indochinese Refugees}

Though it may not be obvious at first glance, the Kokangs have a lot in common with the Indochinese refugees. The ethnic Kokang in Myanmar, like most Indochinese refugees, is of the same ethnicity as the majority of Chinese population, who are known as Han people in China. ${ }^{542}$ The historical and cultural links between the Kokang Region and China are remarkably strong. The Kokang Region, which is now part of Myanmar, was once ceded to China on 1 March 1894 when frontiers were first demarcated in Southeast Asian history, but later returned to Myanmar according to an 1897 agreement between the British and the Chinese. ${ }^{543}$ The region, however, maintained high autonomy prior to the 2009 clash. The Kokangs were very conscious of and cherish their ethnic and cultural heritage and had strongly maintained the language and cultural

\footnotetext{
540 “miandian guogan diqu fasheng zhanshi daliang bianmin yongru wojing [Clashes Took Place in Myanmar's Kokang Region, Large Numbers of Border Residents Poured into China]” (27 August 2009) Yunnan Net $<$ http://yn.yunnan.cn/html/2009-08/27/content_887539.htm> (accessed 26 April 2014).

${ }^{541}$ A possible reason for China's acceptance of the military persons is that commander of the Kokang Army, Peng Jiasheng, who were also the administrative head of the Kokang Region prior to the clash, had maintained good relations with the Chinese government.

542 The Kokang regard themselves as the descent of the Ming Dynasty royal family and scholar-official who fled to the Kokang region some 350 years ago. "guogan gaikuang [Basic Facts of Kokang]" Righteous Kokang $<$ www.righteouskokang.com> (access 8 August 2013).

${ }^{543}$ Sai Kaham Mong Kokang and Kachin in the Shan State (Institute of Asian Studies, Bangkok, 2005) at 31; "Basic Facts of Kokang”, above n 542.
} 
traditions of their Chinese ancestors. ${ }^{544}$ Chinese was the primary spoken and written language in the Kokang Region and many Kokangs did not speak Burmese. ${ }^{545}$ Television, publication, and school education in the Kokang Region were all in Chinese. The region also had very close economic ties with China. The Chinese Yuan instead of the Burmese Kyat was the trading currency in the Kokang Region. ${ }^{546}$ The local government favoured Chinese investments and many businessmen from China had been doing business in the Kokang Region for years.

Interestingly, there was also ambiguity in the nationality status of the ethic Kokangs. Prior to the 2009 clash, the Myanmar central government issued identity cards to the ethnic Kokangs, but a note on the back of their identity cards stated that the holder of the card was not a national of Myanmar and that the card was invalid for entry to areas administered by the Burmese military government. ${ }^{547}$ The ethnic Kokangs consider themselves as having no nationality. ${ }^{548}$

In addition, one shall not forget that a proportion of the Indochinese refugees entered China via Yunnan Province, and the province is still hosting nearly 40 thousand of Indochinese refugees. The common characteristics shared by the ethnic Kokangs and the native Chinese probably mitigated China's fear of the destabilising effect of the influx, and the similarity between the displaced Kokangs and successful integration of the Indochinese refugees might have also increased China's confidence in handling the Kokang Incident.

D Where is China's Refugee Policy Going: the Kachin Influx

\section{$1 \quad$ China's Response to the Kachin Influx}

On 9 June 2011, less than two years after the Kokang Incident, tens of thousands of ethnic Kachins uprooted by armed conflicts between the Myanmar government troops and the ethnic Kachin military group, the KIA, started to flee to areas near the Chinese-Myanmar border. Initially, China only let in a small number of women and children, ${ }^{549}$ but later generally permitted the entrance of displaced Kachins. By late June 2011, more than 5,000 displaced Kachins had entered China, many to temporary camps provided by the local community, others in relatives' homes or rented rooms. ${ }^{550}$ The number was estimated to be between 7,000 and 10,000 in August 2012. The Chinese government provided almost no assistance to the displaced

\footnotetext{
${ }^{544}$ After the 2009 clash, the Burmese central government gained control of the region and forced Burmese education in school and replacement of the Chinese language by the Burmese language in daily life in the Kokang Region.

${ }^{545}$ Hongwei Ying "Guogan jiannan rongru miandian (Kokang Painfully Integrate into Myanmar)" Time Weekly (online ed, China, 17 Jan 2013).

${ }^{546}$ The dominance of foreign currency in Myanmar's border towns is not uncommon. For example, in Tachilek on the Myanmar-Thai border, the Thai Baht instead of Burmese Kyat is used as trading currency.

${ }^{547}$ Liangfei Chen "Guogan 350 nian: shiluo de shijie (350 Years of Kokang: the Lost World)" (9 Sep 2009) Sina News <http://news.sina.com.cn/w/sd/2009-09-09/181518615604_3.shtml> (accessed 6 September 2013).

${ }^{548}$ Myint Myint Kyu "Spaces of Exception and Shifting Strategies of the Kokang Chinese along the Myanmar/China Border" (Master's Dissertation, Chiang Mai University, 2011), at 84; Border Girl, Fu Chen and Gui Chen (dirs) (independent documentary, 2012).

${ }^{549}$ Saw, above $\mathrm{n} 70$.

550 "War Snowballs: Kachin Refugees Influx to China Border" (24 June 2011) Kachin News Group $<$ http://www.kachinnews.com/news/1955-war-snowballs-kachin-refugees-influx-to-china-border.html $>$ (accessed 9 January 2012). The number was estimated to be higher than 8,000 in August 2012 before China returned more than 5,000 displaced Kachins to Myanmar.
} 
Kachins, though several local Chinese NGOs and religious groups as well as Myanmar-based relief groups to access and assist them. ${ }^{551}$ In August 2012, China requested more than 5,000 Kachins in camps to leave China. ${ }^{552}$ Those staying with relatives seem to have been allowed to stay. ${ }^{553}$

The MFA admitted that ethnic Kachins came to China for reasons of safety, but denied that they were "refugees", referring to them as border residents. ${ }^{554}$ The MFA asserted that "Some of them return to Myanmar for work during the day and reside in China temporarily during the night," and that "China has, in the spirit of humanitarianism, devoted a large amount of human resources, money and other materials to supplying humanitarian assistance to these Myanmar border inhabitants." $" 555$

\section{$2 \quad$ Similarities and Differences between the Displaced Kokangs and Kachins}

On the surface, the Kachin influx resembles the Kokang Incident. The two influxes took place within two years of each other, from August 2009 to present. Both displaced groups were from ethnic minority dominated regions with a certain degree of autonomy in Myanmar. Both groups were displaced by military standoff or armed conflicts between the Burmese government troops and local ethnic military forces. Both fled to mid to small size towns close to the ChineseMyanmar border in China's Yunnan Province. Both arrived in large numbers during a short period. Both were referred to by Chinese officials as "border residents". Both were allowed to take refuge in China temporarily, though the length of the time they spent in China varied. In both cases, China declined UNHCR's requests to access the displaced minorities from Myanmar.

Yet the treatment they received in China was different in two significant ways. First, the Chinese government did not provide any assistance to the Kachins except for limited medical service. ${ }^{556}$ Second, unlike the Kokangs, many Kachins encountered difficulties in entering China, and many of them were eventually requested to leave China against their will. Why did China treat them differently?

Above all, it should be noted that the scale of military conflict in Kachin State is much larger than that in the Kokang Region. As of March 2013, more than 100,000 persons have been uprooted by the conflicts in Kachin State, which has a total population of more than 1,200,000, whereas the total population of Kokang Region is less than 150,000, of whom 37,000 took refuge in China in 2009. In terms of civil administration in Myanmar, the Kokang Region is equivalent to a prefecture within Shan State, while Kachin State is equivalent to a province. The Kachin State conflicts uprooted people from several different regions in Kachin State. Not all these regions are as well connected with China as the Kokang Region. Residents in Kachin State

\footnotetext{
${ }^{551}$ Interview conducted by the author (April 2013). See also HRW, above $\mathrm{n} 73$, at 11.

${ }^{552}$ UNHCR "UNHCR Reaches Kachins Sent Back from China”, above n 53.

${ }^{553}$ Interview conducted by the author (April 2013).

${ }^{554}$ MFA press conference, Beijing, 16 June 2011.

${ }^{555}$ MFA's statement released to The New York Times, as cited in Edward Wong and Patrick Zou "Chinese Deny Forcing Refugees to Myanmar" The New York Times (online ed, New York, 25 August 2012).

${ }^{556}$ Interview conducted by the author (April 2013). See Chapter VI.
} 
are eligible to apply for border a pass under the 1997 China-Myanmar protocol. However, many people from remote areas did not apply for it because they did not need to go to China, could not afford the expenses related to the application, or could not provide relevant documents required by the Burmese authorities. ${ }^{557}$ Consequently, not only was the population displaced by the conflicts in Kachin State much larger than in the conflicts in the Kokang Region, but many of the displaced Kachins did not have a border pass. Interviews with ethnic Kachins who crossed into China confirmed that Chinese border security forces did not prevent border pass holders from cross the border, but persons without a border pass encountered difficulties when attempting to enter China. ${ }^{558}$ This suggests that China probably had also relied on the 1997 China-Myanmar protocol to deal with the displaced Kachins. But the large scale of the displacement and the possibly high number of people without a border pass probably significantly reduced China's willingness to open its door to the displaced Kachins.

Notwithstanding the above, many Kachins without a border pass were allowed in later, and many others managed to enter China via the many unofficial pathways along the ChinaMyanmar border. ${ }^{559}$ From June 2011 to August 2012, Chinese authorities generally tolerated their presence in Yunnan Province. According to the Yunnan Province Administrative Rules for Entry-Exit of Foreign Border Residents in Chinese-Myanmar Border Areas, border pass holders, except those who are employed, studying, maintaining a business or receiving medical treatment in Yunnan, are normally allowed to stay in China for 15 days and, subject to approval, to apply for an extension of up to 90 days. ${ }^{560}$ In practice, prior to the clashes in June 2011, border pass holders normally were allowed to stay in China for up to seven days. ${ }^{561}$ It is probably reasonable to say that China has provided temporary protection to the displaced Kachins based on the 1997 China-Myanmar protocol and humanitarian considerations.

Secondly, the cultural and ethnic links between the ethnic Kachins and the native Chinese are weaker than those between the ethnic Kokangs and the Chinese. The Kachin, known as ethnic Jingpo in China, is one of China's 56 officially recognised ethic minority groups. In this sense, the Kachins are similar to the North Koreans, who have their Chinese Korean counterpart in China. The Kachins have a different language from the majority Chinese, the Han Chinese. The Kachins are mostly Christian. These differences could have been seen by China as destabilising elements.

Thirdly, China's strategic and economic interests in the conflicts are believed to have contributed to China's different treatment of the two displaced ethnic groups. ${ }^{562}$ On the one hand, China has bigger investment in Kachin State. Both the Kokang Region and the KIA

\footnotetext{
${ }^{557}$ Interview conducted by the author (April 2013). See ch VI.

${ }^{558}$ Interview conducted by the author (April 2013).

${ }^{559}$ See ch VI.

${ }^{560}$ Article 6 and art 15. The 1997 China-Myanmar bilateral protocol does not mention how long a Border Pass holder can stay after crossing the border.

${ }_{561}$ Interview conducted by the author (April 2013).

562 David Cohen "China's Myanmar Problem" (17 Jan 2013) The Diplomat $<$ http://thediplomat.com/2013/01/chinas-myanmar-problem/> (accessed 19 February 2013).
} 
controlled areas in Kachin State are on the route of the Chinese invested multi-million dollar project, the China-Myanmar oil and gas pipelines, but Kachin State hosts several large hydropower station projects invested in by Chinese state-owned companies, while the Kokang Region is known for the gambling industry. On the other hand, the good relations between the Kokang local army and China in the Kokang Incident is absent between the KIA and China in the Kachin influx. The KIA had expressed dissatisfaction about the biggest Chinese-invested hydropower station project in Kachin State and was reported to have threatened attacking the oil and gas pipelines. Given the close relations between China and the Burmese government, China has mainly relied on the Burmese government to protect its investment interests in Kachin State. In light of the above, China probably was reluctant to assist the displaced Kachins in the same way it assisted the displaced Kokangs.

\section{Conclusion}

Generally speaking, China has been very cautious in recognising the refugee status of displaced foreigners in mass influx situations. In the situation of the North Korean escapees, the displaced Kokangs, and the displaced Kachins, China's security, political, and strategic interests have overshadowed the commitment of China under relevant international treaties. The relations between the Chinese government and the ruling authorities in the country/region of origin of the displaced foreigners concerned have usually been an important consideration in this regard.

Ethnic and cultural links between the displaced foreigners and the majority Chinese population probably have also been an important factor affecting China's receptivity towards displaced foreigners. A likely explanation is that the Chinese government probably considers foreigners who have strong ethnic and cultural links with China as a lesser threat to social stability, which is a top priority of the Chinese government.

China's policy on recognition of refugee status lacks certainty and predictability. This has undermined refugee protection in China. China should develop a consistent policy in line with relevant legal framework. 


\section{Chapter V Procedures and Institutional Framework}

There is no reason to believe that a rigorous but fair refugee determination procedure geared to the present and not hostage to the past should not be in line with China's principles.

- Alexander Casella, former director for Asia at UNHCR ${ }^{563}$

As mentioned above, China has not established any national RSD mechanism. Asylum seekers applying for refugee status in China must make their claims to the UNHCR Office in Beijing. UNHCR is the only organisation that processes individual refugee status applications in China. On several occasions, the Chinese government declined UNHCR's requests to access and conduct RSD for certain groups of displaced persons who were regarded as non-refugees by the Chinese government. In such cases, the Chinese government de facto determined the displaced persons' status through policy decisions. Therefore, it can be said that there are two parallel RSD procedures in China, one implemented by UNHCR, the other one implemented by the Chinese government. Both are discussed below.

\section{RSD Conducted by UNHCR}

\section{A Relations between UNHCR and China}

At present, the operation of the UNHCR Beijing Office includes advocating for respect for the principle of non-refoulement, undertaking RSD under its mandate, identifying durable solutions for all persons of concern, and lobbying for the enactment of national refugee legislation and policies in accordance with international refugee law; the office is also responsible for providing life-sustaining assistance to refugees pending the implementation of appropriate durable solutions, including accommodation, living allowances and access to basic health care. ${ }^{564}$ It highlights the requirement of sustained advocacy efforts and technical advice to promote the enactment and implementation of national asylum legislation as the challenge it faces in China. ${ }^{565}$

The Chinese government claims to have maintained a cooperative relation with UNHCR. ${ }^{566}$ Since the 1980s, China and UNHCR have worked together to support the Indochinese refugees. UNHCR has been involved in the training of relevant government officials and has jointly held several symposiums with the Chinese government on enacting China's national refugee regulation. China has made contributions to UNHCR every year since 1990 (see Chart 8). It contributed USD 250,000 in most years after 1996. There was in a slight increase in 2001 and 2002 and then a sharp increase 2008. It is notable that China successfully entered the World

\footnotetext{
${ }^{563}$ Alexander Casella "Time for China to make legal preparations for acceptance of refugees" (28 May 2013) Global Times <http:/www.globaltimes.cn/content/785010.shtml\#.U1tSpSgoyZY> (accessed 28 April 2014).

${ }^{564}$ UNHCR, above n 41.

${ }^{565}$ UNHCR, above n 290.

566 "China's Relationship with UNHCR", above n 279.
} 
Trade Organisation in December 2001, and hosted the Summer Olympic Games in Beijing in 2008. These two events are widely regarded as milestones of China's integration into the international society and establishing itself as a emerging world power. It is possible that these two events motivated China to make higher contributions to UNHCR in 2001 and 2002 and 2008.

Ironically, China deported 15 UNHCR refugees during "security sweeps" before the 2008 Olympic in Beijing. ${ }^{567}$ In response, UNHCR expressed its concerns, but did not directly criticise the deportations as a violation of the Convention. ${ }^{568}$ In 2008 , the number of asylum seekers registered with UNHCR in China dropped for the first time since 2001 (see Chart 2). UNHCR refugee population also decreased sharply from 180 in 2007 to 70 in 2008 . It was the first time the figure dropped below 100 since 2004 (see Chart 2). This again suggests that refugee protection has not been a priority for Chinese authorities and may be compromised for what Chinese authorities prioritise.

Chart 8 Chinese Government Contributions to UNHCR (USD)

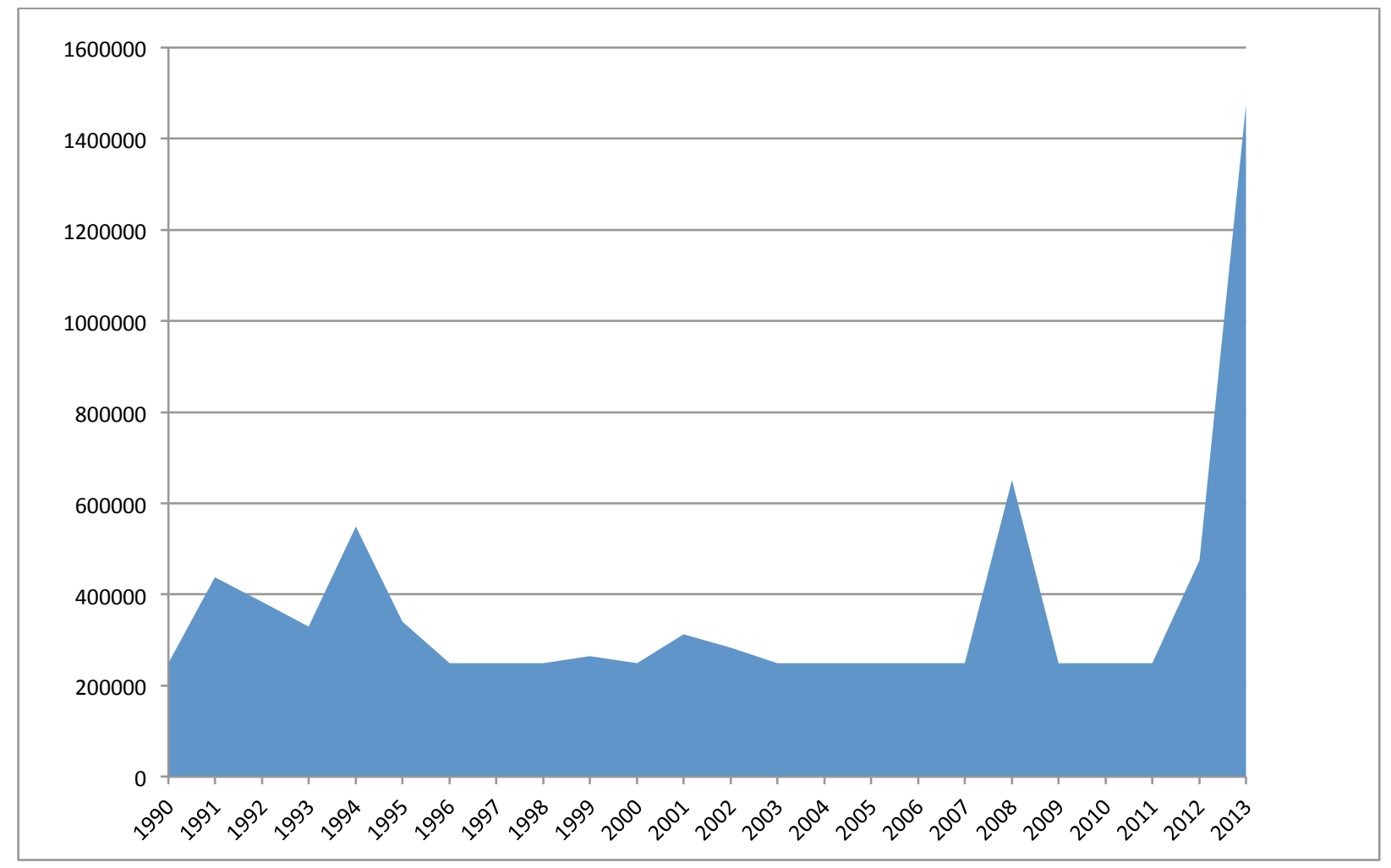

Source: www.unhcr.org; Liang, above n 32, footnote 1 at 254.

567 Stephanie Nebehay "China Deports Refugees Ahead of Olympics: U.N." (8 April 2008) Reuters $<$ http://www.reuters.com/article/2008/04/08/us-china-un-refugees-idUSL086328120080408> (accessed 18 April 2014); UNHCR "China: Concerns over Deportation” (8 April 2008) UNHCR $<$ http://www.unhcr.org/47fb4ed42.html > (accessed 18 April 2014).

568 "On this occasion as always in the past with similar cases, UNHCR has made it clear to China that any deportation of refugees must scrupulously observe the relevant articles of the 1951 Refugee Convention, to which the People's Republic of China is a party, and depending on the circumstances may well constitute a violation of the non-refoulement provision of the Convention." UNHCR, above n 567. 
Most notably, China's contribution increased significantly in the past two years. As at 9 December 2013, China's contribution to UNHCR was nearly USD 1.5 million, representing a more than 210 per cent increase from 2012 and a nearly 500 per cent increase from $2011 .^{569}$ The increase may be linked to the passage of the Exit-Entry Law, which includes the first provisions on refugee treatment in domestic Chinese law, and to the Kachin influx. Although refugee protection is not likely to become a priority for the Chinese leadership in the near future, the increase in China's contribution to UNHCR in the past two years, together with China's response to displaced minorities from Myanmar in recent years as mentioned in chapter IV, may be interpreted as indicating an increasing awareness of the refugee problem and an emerging interest in a more cooperative approach to refugee issues.

The relations between China and UNHCR are not always free from tensions. For example, as mentioned above, more than 30 UNHCR refugees were repatriated in $1992,{ }^{570}$ and 15 UNHCR refugees have been deported before the 2008 Summer Olympic Games in Beijing. In the 1992 Notice, the MPS emphasised that UNHCR had no right to intervene in China internal affairs. ${ }^{571}$ In 2013, China openly warned UNHCR not to make "irresponsible comments" on China's treatment of North Korean escapees. ${ }^{572}$ According to a United States Congressional Research Service report, China was suspicious of UNHCR's intentions and UNHCR could not provide assistance to the North Koreans in an open, transparent manner. ${ }^{573}$

The relations between China and UNHCR could be better understood in the context of China's relations with international organisations. China had been excluded from the UN for 22 years from its establishment in 1949. Although it began to adopt a favourable view of multilateral institutions in the 1980s, concerns about the potential harm to Chinese sovereignty as a result of deeper engagement in the international regime remain. ${ }^{574}$ China was wary of the UN as a rubber stamp of the Western powers at first. It is slow in embracing the traditional human rights values and cautious about UN human rights agencies and other international human rights organisations. ${ }^{575}$ Given China's general attitude towards international organisations, especially international human rights organisations, and the sensitivity of refugee issues in China, its suspicion of UNHCR is not surprising. As mentioned in chapter III, China has drafted a national asylum regulation. When China's national refugee regulation is passed, China will inevitably deal with RSD and other matters relating to refugee protection itself, and hence the role of UNHCR in China is bound to change. Nevertheless, winning the trust and cooperation of Chinese authorities will remain a challenge for UNHCR in China.

\footnotetext{
569 UNHCR "Government Contributions to UNHCR" UNHCR <http://www.unhcr.org/cgibin/texis/vtx/page?page=49e487cd6\&submit=GO> (accessed 23 April 2014).

${ }^{570}$ Liu, above n 359 , at 47.

${ }^{571}$ MPS Notice, above n 394.

572 Jones, above n 515.

${ }^{573}$ Margesson, Chanlett-Avery and Bruno, above n 59, at 11.

${ }^{574}$ Marc Lanteigne China Foreign Policy: An Introduction (Routledge, New York, 2013) at 61.

${ }^{575}$ See generally Sceats and Shaun Breslin, above n 516.
} 
The Chinese government and UNHCR had mutually agreed that RSD should be jointly conducted by both parties. ${ }^{576}$ However, due to the lack of clear legal or administrative provision on responsibilities of each party, in practice the Chinese government has not been substantially involved in refugee status determinations conducted by UNHCR. ${ }^{577}$

According to the UNHCR Procedural Standards for Refugee Status Determination Under UNHCR's Mandate (UNHCR Procedural Standards), each UNHCR office is responsible to develop and implement RSD procedures which should incorporate the UNHCR Procedural Standards and reflect the size of the particular RSD operation, the staffing and other resources available in the UNHCR office, as well as the conditions in the particular country. ${ }^{578}$ In principle, applicants applying for refugee status with UNHCR are required to register with UNHCR, lodge their application forms, and attend an interview with a qualified UNHCR Eligibility Officer in person. Generally, the UNHCR Beijing Office conducts RSD at its premises located in central Beijing for asylum seekers who approach it. Considering the vastness of Chinese territories and that UNHCR only has one office in China's mainland, it can be a challenge for some refugees and asylum seekers to reach the UNHCR Beijing Office. Beijing is by no means close to China's land or sea borders where most refugees and asylum seekers are likely to enter China. Since refugees and asylum seekers often arrive without proper entry documents and with limited financial resources, it would be difficult for them to make their way to Beijing, because they would be subject to identity document checks on the train, at the airport and at hotels.

Alternatively, when it is necessary, UNHCR allows the registration and application form submission procedures to be conducted by approved implementing partners on the condition that it is possible for UNHCR to exercise effective monitoring and supervision and that the approval of relevant UNHCR RSD supervisors is obtained. ${ }^{579}$ Usually, NGOs serve as implementing partners in UNHCR RSD procedures. In China, there are very few, if any, locally-operated NGOs providing assistance to refugees and asylum-seekers in relation to refugee status application (see chapter VI). Therefore, it is difficult for refugees and asylum-seekers to reach UNHCR's RSD service.

In the UNHCR RSD process, interviews of the applicant, however, must be conducted by qualified UNHCR Eligibility Officers and must not be conducted by implementing partners. ${ }^{580}$ Therefore, UNHCR is to "take all feasible steps" to conduct RSD outside UNHCR offices when conditions in the host country make it difficult for asylum-seekers to reach a UNHCR office. ${ }^{581}$ Officials of the UNHCR Beijing Office have travelled to areas outside Beijing, such as Yunnan

\footnotetext{
${ }^{576}$ Wang, above n 373 , at 47.

${ }^{577}$ UNHCR, above n 48; Wang, above n 48.

${ }^{578}$ UNHCR "Procedural Standards for Refugee Status Determination under UNHCR's Mandate" (2003) UNHCR $<$ http://www.unhcr.org/4317223c9.html > (accessed 28 April 2014), at 1-2.

${ }^{579}$ UNHCR, above n 578, at 3-16.

${ }^{580}$ UNHCR, above n 578, at1-6.

${ }^{581}$ UNHCR, above n 578, at 3-16.
} 
and Guangzhou, to conduct RSD. ${ }^{582}$ Where the applicant is identified as a refugee by UNHCR, the person will obtain a permit from the Chinese government which allows him or her to travel within China; the applicant then travels to Beijing. ${ }^{583}$

In reality, the UNHCR Beijing Office does not always have access to refugees and asylum seekers. In 1999, UNHCR sent a team to northeast China near the Chinese-North Korean border; the team assessed the situation of North Korean escapees and determined that some of them qualified as refugees. ${ }^{584}$ China reprimanded UNHCR for this action, ${ }^{585}$ and has not allowed UNHCR to access the Chinese-Korean border area since then. More notably, after North Koreans entered the UNHCR Beijing Office to seek asylum in the early 2000s, the Chinese authorities tightened security around the UNHCR Beijing Office, intentionally making it more difficult for North Koreans to approach UNHCR. The Chinese government also declined UNHCR's repeated requests to access the displaced Kokangs and Kochins in Yunnan in 2009 and 2011 respectively.

UNHCR is sometimes criticised for not confronting the Chinese government about greater protection of the refugees in China. UNHCR officials said that they had worked behind the scenes with Chinese officials to assist with the challenges posed by refugees and asylum seekers and believed this was the most productive way forward. ${ }^{586}$

\section{Refugee Status Determination Conducted by the Chinese Government \\ A Procedures, or the lack Thereof}

China has not established any formal procedures for RSD. Where the Chinese government determined the status of certain displaced persons, the status of the displaced was determined through policy decisions. As mentioned in previous Chapters, Chinese authorities have determined, in effect, the status of at least four displaced groups, namely the Indochinese refugees, the North Korean escapees, the Kokangs, and the Kachins. Except the Indochinese refugees, who were recognised as refugees before UNHCR established its office in Beijing, China did not recognise any of these displaced groups as refugees and generally declined UNHCR's requests to access these groups.

Opacity features in China's decision-making process relating to RSD. The Chinese government never specified which government departments were responsible for processing applications for asylum or assessing the displaced persons' eligibility for refugee status. It typically avoided elaborating the grounds for its decisions and usually did not provide data or detailed information of the displaced persons. For example, when a MFA spokesman was asked at a press conference

\footnotetext{
582 Jing Wan "nanmin wenti yizhi zai fasheng, bushi zhe jiushi na [Refugee Problems always happen, either here or elsewhere]" Southern Weekly (online ed, China, 8 July 2011), available at $<\mathrm{http}: / / w w w . i n f z m . c o m / c o n t e n t / 61090>$ (accessed 8 August 2013). This article includes the transcript of an interview with Choosin Ngaotheppitak, then Head of UNHCR Hong Kong Office, who served for four years in UNHCR Beijing Office between 2003 and 2007.

${ }^{583}$ Wan, above n 582.

${ }^{584}$ USCRI "U.S. Committee for Refugees World Refugee Survey 2002 - China (Including Tibet)" (10 June 2002) Refworld < http://www.refworld.org/docid/3d04c14c10.html> (accessed 25 April 2014).

${ }^{585}$ USCRI, above n 584.

${ }^{586}$ Margesson, Chanlett-Avery and Bruno, above n 59, at 11.
} 
on 27 April 2004 whether Chinese authorities identified North Korean illegal border crossers as economic migrants on a prima facie basis or after investigating individual situations, he replied, "They entered China because of economic reasons. I think that, if their life was not difficult, they would not have left their home country". 587

Whereas Chinese authorities routinely declined to comment on how they determined the status of the North Korean escapees and the displaced Kokangs and Kachins, it is highly likely that the decisions were made on a general basis. There is no evidence that Chinese authorities have conducted interviews with the North Koreans or ethnic minorities from Myanmar or investigated situations of displaced individuals in order to determine their status, although Chinese officials obtained basic information, such as name, age and the name of their home village, about the displace Kachins in Yunnan during the Kachin influx. Given the scale of these displacements, it is not unreasonable for China to determine their status prima facie as a group for initial emergency response. However, whenever circumstances permit, individuals should be given the opportunity to make claims for refugee status and to have their situation assessed by competent parties. This does not seem to have been the case in terms of China's treatment of the North Korean escapees and the displaced Kokangs and Kachins (see chapter VI). For example, as mentioned above, UNHCR has generally been prevented from accessing the North Korean escapees and the Kokangs and Kachins, and North Korean escapees who attempted to apply for refugee status with the MFA was taken away arbitrarily by the Chinese authorities.

There may be a few reasons for China's adoption of the "group approach" in determination of these groups' status. One possible explanation is that the displaced persons' individual situation would make little difference to China's decision on the status of a certain group when China's political, strategic and security considerations outweighed its commitment to the Convention and Protocol and its humanitarian considerations. In other words, factors other than a displaced person's specific situation were decisive in China's decision-making process. Therefore, investigation into a displaced person's individual situation would become unnecessary and even undesirable to Chinese authorities. The experience of North Korean escapees in China is a case in point. For example, on 26 August 2002, seven North Korean escapees (known as the MoFA Seven) attempted to apply for refugee status at MFA. ${ }^{588}$ They were immediately taken away and then investigated by Chinese public security authorities. ${ }^{589}$ A MFA spokesperson later referred to them as demonstrators with unknown identity and said that their behaviour severely violated Chinese law regarding assembly and demonstration. ${ }^{590}$ In February 1996, when a North Korean escapee identified himself to the Chinese security officials as a North Korean army captain although Chinese officials obtained basic information, such as name, age, and the name of the home village, of the displaced Kachins in Yunnan during the Kachin influx seeking political

\footnotetext{
${ }_{587}^{587}$ MFA press conference, Beijing, 27 April 2004.

${ }^{588}$ MOUonekorea "Exploring the Connection between China and North Korea: Seoul Train Part 1" (20 January 2012) One Korea <https://mouonekorea.wordpress.com/2012/01/20/exploring-the-connection-between-china-andnorth-korea-seoul-train-part-1/\#more-899> (accessed 17 March 2014).

${ }_{589}$ MFA press conference, Beijing, 5 September 2002.

${ }^{590}$ MFA, above n 589.
} 
asylum, he was only to be told by an official that "we do not recognize political asylum seekers". 591

Another factor needs to be considered is that China is unlikely to be well equipped with RSD techniques to conduct individual screening at present, not to mention the lack of clarity as to which government body is responsible for RSD. Chinese officials probably have little experience, if any, in assessing individual application for asylum. As mentioned in previous Chapters, the Indochinese refugees were granted refugee status on a prima facie basis. Chinese authorities do not seem to show good understanding of the Convention and Protocol. Additionally, despite of the arrangement between the Chinese government and UNHCR on cooperation in RSD procedures, the Chinese government has essentially refrained from being involving in the RSD conducted by UNHCR. Of course, technical difficulties should by no means serve as an excuse for preventing the displaced persons from accessing UNHCR to use their RSD service.

Several Chinese government bodies are involved in refugee administration in practice, including the MFA, the MCA (in particular ORSIRs), the MPS and certain provincial governments (see discussion below). It is clear that the ORSIRs only deal with the Indochinese refugees and have not been involved in handling non-Indochinese refugees. However, there are no established guidelines defining the other departments' roles and responsibilities regarding refugee matters.

Examination of China's handling of the Indochinese refugees, the North Korean escapees and displaced ethnic minorities from Myanmar may cast light on who the decision makers actually are. In terms of the Indochinese refugees, the recognition of their status as refugee was officially announced at the 1979 Conference, which was presided by then Chairman of China, Li Xiannian and then Vice Premier of the State Council (the Central Government of China), Chen Muhua. Officials from 18 ministries and departments as well as provincial leaders from Guangxi, Guangdong (Hainan was part of Guangdong at the time), Yunnan, Jiangxi and Fujian were present at the conference. ${ }^{592}$ It showed that the matter was taken care of by the central government at a top level. In comparison, the repatriation of the Lao and Cambodian refugees was organised and implemented by the local authorities in Yunnan Province according to a joint decision by the MCA and the MFA. ${ }^{593}$

In the case of North Korean escapees, the Chinese government primarily channels its policy on North Korean escapees to the public through the MFA's regular press conferences. This does not necessarily mean the decision comes from or solely comes from the MFA. As exemplified by the case of MoFA Seven, it was usually public security authorities that directly dealt with North Korean escapees in China. North Korean escapees reported having been questioned, denied opportunity of being assessed for refugee status and repatriated by Chinese public security

\footnotetext{
${ }^{591}$ HRW, above n 59.

${ }^{592}$ Liang, above n 32, at 273. Hainan Province was part of Guangdong Province at that time.

${ }^{593}$ Liang, above n 32, at 303; Li, above n 426.
} 
bureaus (PSBs). ${ }^{594}$ According to art 31 of the Convention, refugees should be exempted from measures against general illegal border crossers. In other words, the MPS is given the task of handling the North Korean escapees assuming they are not exempted from these measures.

During the Kokang Incident in 2009, then Minister of MPS, Meng Jianzhu was sent to Yunnan in response to the Incident. The Yunnan PSB held a special press conference on 31 August 2009 to comprehensively explain the situation of the displaced Kokangs in China. The fact that the press conference was held by a local level authority rather than a national level authority suggests that the Incident was treated with relatively low importance by the China government. In comparison, no special conference press was held regarding the Kachin influx. The MFA mentioned that the Kachins were not refugee at its regular press conferences in reply to questions raised by journalists. The local authorities in Yunnan were quoted as sources of information in mainstream Chinese media. It is believed that the Kachin influx was dealt with by local authorities of border towns hosting the displaced Kachins, but higher level authorities took charge later. ${ }^{595}$

\section{B Institutional Framework}

The background for understanding the institutional framework for refugee management in China is that there is no unified immigration administrative authority in China. Immigration administrative functions are distributed between the MPS and the MFA (art 4, Exit-Entry Law). These ministries operate at various central and local government levels. Border Control Troops under the leadership of the MPS are responsible for preventing illegal border-crossing and human trafficking. ${ }^{596}$

Three government bodies officially have the responsibility to deal with refugee matters: the MCA, the MFA, and the MPS, although their respective roles in handling refugee matters probably have not been clearly defined at present.

\section{Ministry of Civil Affairs and Offices of Reception and Settlement of Indochinese Refugees}

The MCA was established in 1978. The predecessor of the MCA is the Ministry of Internal Affairs established in 1949, which was mainly responsible for providing disaster relief and strengthening the institutional system of the newly founded People's government. The Ministry of Internal Affairs was removed during the Cultural Revolution in 1969, and the MCA was given similar responsibilities when it was established in 1978.

The MCA shouldered a leading role from a very early stage of China's reception of the Indochinese refugees. The MCA continues to play a major role in supporting the Indochinese refugees nowadays. It is also responsible for drafting China's national refugee regulation.

According to the MCA website, two of the MCA's main functions are to "participate in drafting administration rules on international refugees in China, and jointly take charge of temporary

\footnotetext{
${ }^{594} \mathrm{HRW}$, above $\mathrm{n} 59$, at 16.

${ }_{595}^{5}$ Interview conducted by the author (April 2013).

${ }^{596}$ Liu, above n 15 , at 17.
} 
settlement and repatriation of international refugees in China with other relevant departments". ${ }^{597}$ As mentioned in Chapter III, the MCA is involved in drafting China's national refugee regulation. Specifically, this function is performed by the International Cooperation Sector and the Policy and Regulation Sector of the MCA. ${ }^{598}$

The refugee settlement and repatriation function of the MCA is performed through the State Council ORSIR and its branches at local level. The State Council ORSIR was established in 1979. At the 1979 conference, the task of settling the Indochinese was transferred from the State Council Overseas Chinese Affairs Office to the then newly established State Council Leading Group for Reception and Settlement of Indochinese Refugees. The Group was headed by then Minister of Civil Affairs; persons in charge of the State Council Overseas Chinese Affairs Office, MFA, Ministry of Agriculture and China Red Cross served as deputy heads. ${ }^{599}$ The Group established an office under the MCA, which is known as the State Council ORSIR. Branches of the State Council ORSIR were soon established in autonomous regions and provinces where Indochinese refugees were hosted.

Nowadays, ORSIRs operate at national, provincial and municipal levels. At the national level, the State Council ORSIR is placed under the MCA International Cooperation Sector. There are ORSIRs in Guangxi, Yunnan, Guangdong, Hainan, Fujian and Jiangxi at the provincial level. In cities and counties where there are large numbers of Indochinese refugees, such as Nanning, Beihai and Pingxiang in Guangxi, ORSIRs were also set up at municipal level; in cities and counties where no ORSIR is established, the local Overseas Chinese Affair Office (OCAO) takes charge of the reception and settlement of the Indochinese refugees. ${ }^{600}$ In Guangxi, Guangdong, Hainan, Fujian and Jiangxi, the provincial ORSIR either doubles with a department of the provincial OCAC or is under the leadership of the provincial OCAO. This probably suggests that, to some extent, the Indochinese refugees in China are still treated as returned overseas Chinese.

As their name suggests, ORSIRs only deal with Indochinese refugees. They have not been involved in non-Indochinese refugee matters. ORSIRs are given a wide range of responsibilities relating to the Indochinese refugees in China, including protecting the rights and interest of the Indochinese refugees, researching and studying new circumstances and issues relating to refugee work, accepting assistance from UNHCR and other international organisations, implementing and managing assistance programs, accepting and accessing Indochinese refugees' application for family reunion or resettlement in third countries, assisting in repatriation and naturalisation

\footnotetext{
597 "minzhengbu zhuyao zhize [Main Duties and Responsibilities of Ministry of Civil Affairs]" MCA, $<\mathrm{http}$ ://www.mca.gov.cn/article/zwgk/jggl/zyzz/> (accessed 2 August 2012).

${ }^{598}$ MCA Administration Office Notice regarding Circulation of MCA Legistative Work Plan (29 July 2013), Chinese version available at $\quad$ MCA $<$ http://210.73.66.144:4601/law? $\mathrm{fn}=$ chl394s435.txt\&truetag=846\&titles $=\&$ contents $=\& \mathrm{dbt}=\mathrm{chl}>($ accessed 25 April 2014)

${ }^{599}$ Liang, above n 32, at 275.

${ }^{600}$ Liang, above n 32, at 275.
} 
of Indochinese refugees, taking charge of skill training and employment of the Indochinese refugees, and supervising the usage of refugee related funds. ${ }^{601}$

ORSIRs are UNHCR's implementing partners for local settlement and voluntary repatriation of the Indochinese refugees. ${ }^{602}$ UNHCR assistance to Indochinese refugees in China is channelled through the MCA, and ORSIRs are responsible for the overall implementation of relevant projects. ${ }^{603}$

Although the majority of the Indochinese refugees in China have become self-sufficient, ORSIRs provide continuous support to the Indochinese refugee community, such as occupational training and small loans to needy refugees. Officials of ORSIRs at national and provincial levels meet yearly, usually in one of the six provinces or autonomous regions hosting Indochinese refugees. ORSIR meetings consider matters relating to supporting the Indochinese refugee community in China and finding durable solutions for them. For example, the meeting in 2013 was held in Hainan and focused on potential issues relating to permanent settlement of the Indochinese refugees in China and relevant possible plans.

Besides ORSIRs' work with the Indochinese refugees, the MCA provided assistance to the displaced Kokangs in 2009. The tents and blankets provided to the Kokangs by Chinese authorities were printed with characters "China Civil Affairs Disaster Relief”. Considering that the MCA is given the task of drafting China's national refugee regulation, it is likely to become an important player in China's national RSD mechanism in the future. In particular, ORSIRs' operation network and their staff with experience of dealing with Indochinese refugees and implementing UNHCR assistance programmes would be valuable sources upon which the Chinese government can draw to build its national refugee protection system.

\section{$2 \quad$ Ministry of Foreign Affairs}

The MFA is responsible for foreign relations between China and other countries as well as international organisations. It is stated on the MFA's website that one of the MFA's main functions is to "handle global and regional security, political, economic, human rights, social, refugee and other diplomatic affairs in the United Nations and other multilateral fora"; it is also responsible for assisting "in examining foreign-related draft laws and regulations" and for organising and coordinating "the work of fulfilling international conventions and agreements". 604

Generally speaking, all matters involving a foreign element may fall under the MFA's authority in China. Due to the international nature of refugees, the MFA's involvement is natural. Like the

\footnotetext{
601 "Hainansheng jiedai anzhi yinzhi nanmin bangongshi [Hainan Province Office of Reception and Settlement of Indochinese Refugees]" (14 November 2007) The People's Government of Hainan Province $<\mathrm{http} / / / \mathrm{www}$.hainan.gov.cn/data/kstd/2007/11/147/> (accessed 1 September 2013).

${ }^{602}$ UNHCR "Activities Financed by Voluntary Funds: Report for 1993-1994 and Proposed Programmes and Budget for 1995 Part II. Asia and Oceania Section 4 - China”, A/AC.96/825/Part II/4 (1994) at [9].

${ }^{603}$ UNHCR "Update on Regional Developments in Asia and Oceania”, EC/46/SC/CRP.44 (1986) at [78].

604 "Main Responsibilities of the Ministry of Foreign Affairs of the People's Republic of China", MFA $<$ http://www.fmprc.gov.cn/eng/wjb/zyzz/> (accessed 2 August 2012).
} 
MCA, the MFA assumed a major role during the Indochinese refugee crisis. The Foreign Minister at that time was appointed as one of the four deputy heads of the Leading Group for Reception and Settlement of Indochinese Refugees in 1979. It also made the decision, jointly with the MCA, to entrust the task of repatriating Lao and Cambodian refugees to the Yunnan provincial government.

Nowadays, the MFA, through its regular press conferences, serves as the main source of China's policy towards displaced foreigners in China and, perhaps because of that, is usually perceived as a major Chinese government body responsible for refugee protection in China. For instance, as mentioned above, seven North Korean escapees who hoped to acquire refugee status through official procedures attempted to lodge their applications at the MFA.

Indeed, the MFA is a key player in handling refugees in China. This is perhaps because China has generally relied on non-public diplomatic negotiations to tackle the refugee problem on an ad hoc and case-by-case basis. For instance, the MFA was involved in negotiations with relevant foreign embassies and consulates with respect to the departure of North Korean escapees who entered these embassies and consulates for asylum. China also exercised influence via diplomatic channels on the government of Myanmar during the Kachin influx. ${ }^{605}$

In addition, the MFA's role involves liaising with the Office of UNHCR in China. For example, as mentioned above, the MFA has organised a number of symposia on asylum legislation jointly with UNHCR in China in the past few years.

Since the Chinese government mainly interacts with the UNHCR Beijing Office through the MFA, the MFA probably is the Chinese government department best informed of the international refugee protection regime. Besides, it is in the position to provide the information of the country of origin of the refugees. Therefore, it is most likely that the MFA will also be an important player in China's future national RSD mechanism.

\section{Ministry of Public Security}

The MPS is China's principle police and security authority, responsible for a broad spectrum of matters ranging from public order administration, criminal investigation and counter-terrorism to border control, household registration and identity card administration. The MPS operates the nationwide system of PSBs, which serve as police stations in China and perform many of the MPS duties on a day-to-day basis at different local levels. There are a number of bureaus and departments under the MPS, such as the Bureau of Exit and Entry Administration (BEEA), the Border Control Department (BCD) and Fire Departments; many of these departments operate outside the PBS system at local levels.

The legal ground of the MPS involvement in refugee matters is two-fold. First, public security authorities are responsible for issuing refugee identity cards to refugees and temporary identity cards to asylum seekers (art 46, Exit-Entry Law). PSBs are in charge of the issuance and

${ }^{605}$ Interview conducted by the author (April 2014). 
administration of identity cards. Normally, a person's identity card is issued by the district PSB with which the person's household registration is maintained. ${ }^{606}$

Second, public security authorities are in charge of border control. This function is performed through the BEEA, the BCD, their local branches and the PSBs. The BEEA primarily takes care of border control at nine major cities (Beijing, Shanghai, Tianjin, Guangzhou, Shenzhen, Zhuhai, Shantou, Haikou and Xiamen), ${ }^{607}$ while the border control troops under the BCD's leadership are responsible for guarding land and costal border elsewhere. ${ }^{608}$ The border control troops are part of the People's Armed Police, and are stationed at border areas to, among other things, prevent illegal border crossing, human trafficking and smuggling of goods and drugs. BEEA, $\mathrm{BCD}$ and PSBs at county level or above are authorised to investigate, detain and repatriate illegal border crossers (art 58, Exit-Entry Law).

\section{Conclusion}

Generally speaking, UNHCR processes individual applications for refugee status in China, whereas the Chinese government has de facto determined the status of displaced foreigners who arrived in China in large numbers through policy decisions.

The Chinese government's decision-making process relating to the status of relevant displaced foreigners lacks transparency and predictability. China should establish a national RSD mechanism as soon as possible. Before the Chinese national RSD mechanism is established, asylum seekers should have unrestricted access to UNHCR's RSD service.

\footnotetext{
${ }^{606}$ Identity Card Administration Law 2003 (China), art 7.

607 "churujing bianfang jiancha zongzhan ji xiashu churujing bianfang jianchazhan [Exit-Entry Inspection Head Station and Exit-Entry Stations under It" (3 July 2008) Bureau of Exit and Entry Administration of the MPS $<$ http://www.mps.gov.cn/n16/n84147/n84165/1291480.html > (accessed 19 October 2013).

${ }^{608}$ Liu, above n 15 , at 18.
} 


\section{Chapter VI Reality at the Border and Voices from Refugees and Humanitarian Workers}

We had little money, but we put our money together to buy gifts and went to the police station to apply for refugee status.

- A Kachin interviewee

\section{Methodology}

As refugees remain a highly sensitive topic in China, the Chinese government has disclosed little information of its decision making process regarding RSD or the treatment of refugees and other displaced foreigners. UNHCR is generally barred by the Chinese government from accessing the North Korean escapees, the displaced Kokangs, and the displaced Kachins, and hence is unable to provide first-hand information of the treatment of these groups. Journalists in China, both foreign and Chinese, either pay inadequate attention to or are restricted from covering refugees. Therefore, refugees and other displaced foreigners become a valuable and relatively accessible source - they are by no means easy to reach - of information regarding RSD procedures and methods employed by the Chinese authorities and how refugees and other displaced foreigners are treated during the process.

Given the small volume of literature on refugees and other displaced foreigners in China, it is unsurprising that very little empirical research has been conducted with refugees and other displaced foreigners in China. In 2011 and 2012, HRW interviewed displaced Kachins in Yunnan, China and revealed in its report that the local authorities in Yunnan conducted "some sort of interview" with the displaced Kachins to gather basic information about them. ${ }^{609} \mathrm{~A}$ number of researchers and organisations have managed to interview North Korean escapees who were living or had lived in China. ${ }^{610}$ Interviews with Vietnamese refugees in China can be seen in Chinese media occasionally, but most of them, if not all, were not conducted or documented in a manner that facilitates academic analysis. Interviews conducted by Lam with Vietnamese refugees and people working with them in Guangdong and Guangxi were a rare effort of empirical investigation on the settlement of the Vietnamese refugees and China's refugee settlement strategy, although he did not look at the decision making process relating to the refugees status of the Vietnamese. ${ }^{611}$

The primary aims of my field research were, on the one hand, to obtain first-hand information of interactions between refugees and other displaced foreigners and the Chinese authorities with a

\footnotetext{
${ }^{609}$ HRW, above n 73 .

${ }^{610}$ Eg Mikyoung Kim Securitization of Human Rights: North Korean Refugees in East Asia (Praeger, Santa Barbara (CA), 2012); Haggard and Marcus, above n 59; Han, above n 89; HRW, above n 59.

${ }^{611}$ Lam, above n 36.
} 
focus on refugee status determination procedures and, on the other hand, to make the voice of the often silenced refugee community heard. From 26 March to 30 April 2013, I conducted interviews with two North Koreans, one Vietnamese, and seven Kachins (collectively Category I participants). Complementarily, six employees of international organisations and nongovernmental working with Category I participants (collectively Category II participants) were also interviewed for their observations of interaction between Category I participants and the Chinese authorities, including an employee of an NGO working with North Koreans, two employees of an aid group working with displaced Kachins, two persons helping displaced Kachins as independent humanitarian workers, and an employee of an international organisation working with displaced population.

As acknowledged by Sawyer and Blitz: ${ }^{612}$

[c]onducting research on refugees, asylum seekers ... is notoriously difficult. Not only are such populations often out of reach, ... but there is little official information recorded on the population of interest.

This is particularly true with refugees and other displaced foreigners in the Chinese context given the sensitivity of the issue and the vulnerable condition of the refugees and other displaced foreigners in China. As mentioned in previous chapters, North Korean escapees in China are in an extremely vulnerable situation. They are considered to be illegal economic migrants in China and have to live in hiding. They face deportation if their identity is revealed to the Chinese authorities. In addition, humanitarian workers assisting North Korean escapees may also face penalty or expulsion from China if they attract attention from the Chinese authorities. Because of security considerations, North Korean escapees interviewed were those who no longer live in China at the time of the interview. Likewise, the interviewed humanitarian worker assisting North Korean escapees was not based in China.

In terms of the displaced Kachins who remain in China, ${ }^{613}$ they do not have a legal status and therefore do not have a guaranteed right to stay in China. They are still at risk of removal. Considering that Chinese authorities have tried to avoid public attention on the displaced Kachins, the displaced Kachins remaining in China were not approached. Instead, interviews were conducted with those who had been pushed back to Myanmar. With only one exception, all humanitarian workers interviewed, who were helping the displaced Kachins, were not based in China.

Regarding the ethnic Kokangs who were provided refuge in China in 2009, they voluntarily returned to the Kokang Region, Myanmar in September 2009. Entry to the Kokang Region from

${ }^{612}$ Caroline Sawyer and Brad Blitz Statelessness in European Union (Cambridge University Press, Cambridge, 2011) at 141.

${ }^{613}$ After the Chinese authorities repatriated about 5,000 displaced Kachins who were living in camps in August and September 2012, there remain estimated 2,000 to 3,000 displaced Kachins in Yunnan. Most of them stay with relatives. See Ch IV. 
both China and inside Burma was heavily restricted at the time of the interview. ${ }^{614}$ Due to security concerns as well as the time and budget limitations of the project, the Kokangs were not interviewed.

Although the Indochinese refugees have been officially recognised as refugees by the Chinese government, they remain a community that the Chinese government much prefers to be invisible to the Chinese society, as demonstrated by my experience with the Guangxi Provincial ORSIR below. Since ORSIRs are responsible for taking enquiries regarding Indochinese refugees from the public, I contacted Guangxi provincial ORSIR twice by phone to enquire if they could assist in putting me in contact with Indochinese refugees residing in or around Nanning, the capital city of Guangxi or give information such as the name of Overseas Chinese farms where the Indochinese refugees reside. ${ }^{615}$ On both occassions, the officer who answered the phone declined to offer assistance or give any information of the Indochinese refugees locally integrated. One officer said that they were not authorised to release information of the Indochinese refugees and that, in order to acquire information of the Indochinese refugees from ORSIR in Guangxi, one needed to obtain approval from the State Council. Another officer said she had to ask her supervisor's approval on the matter and came back with the advice for me to not write about the Indochinese refugees.

Apart from the general difficulties in accessing refugees and other displaced foreigners, budget and time limitations resulting from the scale of this research further restricted options for selecting participants. For example, I did not have the budget to pursue interviews with North Korean escapees who may require monetary or material compensation for the interview. ${ }^{616}$ I did not have the time and budget to go through the procedures for applying a special permit for foreigners to visit Kokang Region which can be lengthy and nearly inevitably involves "tea money" (bribes) to the Burmese officials in Yangon.

Sixteen participants were eventually recruited, mainly through personal contacts. Ten were Category I participants; six were Category II participants. I also spoke with a number of independent humanitarian workers and Kachin officials although did not formally interview them. Seven Kachin Category I participants and two Category II participants were recruited with the help of the IDPs \& Refugees Relief Committee of the Kachin Independent Organisation (KIO) which I contacted through a Category II participant. ${ }^{617}$ Except the Vietnamese refugee and

\footnotetext{
${ }^{614}$ On the Chinese side, the Nansan (China)-Kokang (Myanmar) crossing does not open to foreigners except citizens of Myanmar with a border pass; Chinese citizens who do not reside in the border area are not allowed to exit from Nannan unless they are going to the Kokang Region for business and can provide an invitation letter from business partners in the Kokang Region. In Myanmar, the Kokang Region is located in the so-called "black area" where foreign visitors are generally forbidden.

${ }^{615}$ Unlike many Chinese government departments, ORSIRs do not have an official website. No contact emails could be found for Guangxi Provincial ORSIR.

${ }^{616}$ It is a common practice for North Korean escapees living in South Korea to request monetary or material compensation for interviews with them.

${ }^{617}$ The Kachin Independent Organisation (KIO) is the civilian wing of the Kachin Independent Army (KIA). The IDPs \& Refugees Relief Committee was established by the KIO in 2009 with the responsibility of looking after displaced Kachins.
} 
an independent humanitarian worker assisting displaced Kachins, none of the participants were residing in China.

Generally, except the Vietnamese participant, all Category I participants entered China between 2005 and 2012. The length of their stay in China varied from more than 30 years to five months, but 70 per cent of the participants spent between six years to ten months in China.

Representativeness are not at issue in this fieldwork. The main object is to illustrate interactions between the Chinese authorities and displaced foreigners and how relevant law and policy is implemented on the ground. The benefit of this fieldwork, first and foremost, is to allow the freedom of articulating often silenced thoughts of the displaced persons who sought refuge in China.

Most of the interviews were one-on-one face-to-face interviews which generally followed an interview schedule designed for each category. One group interview was conducted with five Kachin Category I participants due to lack of suitable venue for individual interviews. One interview with a Category II participant was conducted by email after attempted phone interview became difficult due to unstable mobile signals in the region of the participant.

Interviews were conducted in a number of languages, including English, Mandarin Chinese, Cantonese, Korean and Kachin. Most of the Category I Participants were interviewed in their native language. The two North Korean participants both spoke Korean and Mandarin Chinese and were both offered the opportunity to choose the language they prefer to speak during the interview. One of them chose to speak Mandarin Chinese. The other preferred to speak Korean and a Korean-English interpreter was present during the interview. The Vietnamese participant was interviewed in Cantonese. All Category I Kachins participants were interviewed in Kachin with Kachin-Chinese or Kachin-English interpreters. In terms of the Category II Participants, all interviews were conducted in English, except one interview in Mandarin Chinese.

Interviews with Category I participants were mostly conducted in a semi-formal atmosphere, set in school or hotel meeting rooms or hotel rooms; exceptionally, one Category I participant was interviewed at her home and at a garden within the private residence compound where she was living. Interviews with Category II participants (except an email interview) were set in meeting rooms as well as more casual places, such as quiet cafes and private dining rooms suggested by the participants. When interviews were not conducted in a private space, careful measures were taken to ensure the content of the interview remain confidential. No participants received any payment or reimbursement for the interview.

The length of the interviews varied from 25 minutes to one hour and 35 minutes, mainly depending on the number of participants involved, whether an interpreter was used and whether the interview was conducted in a semi-formal or casual atmosphere.

The interviews were semi-structured. An interview schedule was prepared for Category I and Category II participants respectively and was generally followed. Interviews normally started with a few preliminary questions relating to the general information of the participants, such as 
how long he or she stayed in China (in terms of Category I participants) or had been working with refugees (in terms of Category II participants), followed by questions regarding the Chinese authorities' treatment of displaced foreigners at the international border, during their stay in China and during their departure from China. Additionally, Category I participants were also asked if they tried to contact the office of UNHCR in China and their preference on repatriation, local settlement and third country resettlement, whereas Category II participants were asked if there was any particularly pressing issue that they would like to comment on. However, taken into consideration of participants' varying background and reactions during the interview, not every Category I or Category II participant was necessarily asked the same questions.

Section II of this chapter, based on my visit to Nabang (China)/Laiza (Myanmar) and Zhangfeng (China)/Mai Ja Yang (Myanmar) in mid April 2013, illustrates how cross-border movements were controlled along the Chinese-Myanmar border. This section provides background for understanding the response of the displaced Kachins in sec III.

The response of the participants is presented below in sec III largely following the above mentioned sequence of clusters of interview questions. Where the interview was conducted in English or through an English interpreter, participants are quoted in their original words or as per the interpreter's interpretation. Most of the participants interviewed in English as well as one Kachin-English interpreter are not native English speakers; when they are quoted, grammatical errors, if any, are retained. Where the interview was conducted in Mandarin or Cantonese, the translation is done by the author and rendered in a manner as faithful as possible to the original response of the participants, showing repeated words and unfinished sentences contained in the original conversation. The intention for presenting the quote in this way is to relay the voices of the participants as intact as possible. In several quotes, however, a few words are added in square brackets to include important information which was clear in the original context of the interview but is otherwise not shown in the quote. It should also be mentioned that sometimes interpreters used third person rather than first person when interpreting participants' reply; in this case, the third person is replaced with first person when the participant is quoted.

\section{Reality at the Chinese-Myanmar Border: Nabang/Laiza and Zhangfeng/Mai Ja Yang}

I visited four border towns on the Chinese-Myanmar border between 10 April and 14 April 2013, namely Nabang and Zhangfeng in the Yunnan Province, China and Laiza and Mai Ja Yang in Kachin State, Myanmar. Nabang lies within Yingjiang County, Dehong Dai and Jingpo Autonomous Prefecture in the west of Yunnan Province. It has a population of around 1,600. Across the Chinese-Myanmar border river from Nabang is Laiza, the headquarters of the KIA. Zhangfeng is located within Longchuan County, Dehong Dai and Jingpo Autonomous Prefecture. Its population is about 12,800. Zhangfeng connects with Mai Ja Yang, Kachin State, Myanmar.

Both Nabang and Zhangfeng looked peaceful and orderly during my visit. There was, however, a check point guarded by armed soldiers near Nabang on the main road linking Nabang and 
Yingjiang County's administration centre. Local residents said that the check point was established after the conflict. The check point looked basic and temporary, merely a couple of military-looking dark green tents erected on the side of the road, equipped with a few desks and computers. Each vehicle entering or exiting Nabang via the main road had to stop at the check point. In my case, an armed young soldier came on the public mini bus I was taking and politely required all passengers on board to produce their identity cards. A few passengers who did not bring their identity card with them were requested to report the name of their tribe or village instead. The soldier collected and took away the identity cards to the tent. The soldier returned shortly to hand the ID cards back to the passengers and requested two passengers to leave the bus for "checking". One of the passengers later returned in handcuffs. His belongings, contained in a small plastic bag, were taken away by the soldiers. According to the bus driver and the local passengers on the bus, that passenger was charged with drug trafficking which is not uncommon in the area. Our bus was allowed to pass shortly after.

The check point near Nabang seemed to perform some drug control functions which were believed to be the main purposes of the check point by local residents. Drug trafficking and usage is one of China's concerns which undermine its hospitality towards the displaced Kachins. ${ }^{618}$ In addition, the check point is probably used to control the movement of people; a Category II participant mentioned that displaced Kachins who attempted to leave the border town to go to cities were intercepted by the Chinese authorities.

The Chinese-Myanmar borders at Nabang and Zhangfeng were not heavily guarded. At many places, the border is inhabited on both sides and residents on both sides form a close community, where many people cross the border on a daily basis to visit friends and relatives or to purchase groceries. ${ }^{619}$ For example, the busy business and residential area of Nabang town lies right next to the Chinese-Myanmar border river. When I visited Nabang in mid-April 2013, the water in the border river was ankle high. There is an official crossing near a bridge (known as guomen (national gate) by local residents) at Nabang, but people from both side frequently waded the river near their home for convenience instead of going through the official crossing. The river per se is also a popular playground of local children. A resident of Nabang said that border police rarely - only two or three days in a month - patrol along the river to prevent unofficial crossings.

A local resident said that there had been no massive influx of displaced Kachins into Nabang. He was aware of the camps built by the Chinese government although he declined to take me to where they were. In comparison, camps built by the KIA were more visible and accessible. There are nine IDP camps at and around Laiza. Most of them were very close to the border, some visible from Nabang.

\footnotetext{
${ }^{618}$ HRW, above n 73 .

${ }^{619}$ This is at least partly due to the historical reasons. This part of Myanmar historically has close links with China. There are about 132 thousand Kachins (known as ethnic Jingpo in China) people living in Yunnan Province. The border line was first survey by the British and China in the late 1800s. China and Burma exchanged lands under the 1897 bilateral agreement and under the 1960 bilateral agreement. For more information, see Mong, above n 543.
} 
One of these camps was built on the bank of the border river near a wooden bridge. Neither end of the bridge was guarded. Opposite to the overcrowded bamboo shelters on the Myanmar side of the river, the Chinese side of the river was quiet and wild, largely uninhabited. People living in the camp had no difficulty in crossing the bridge to go to the Chinese side of the river. I was near the bridge for about 10 minutes and saw a few people cross the bridge from Laiza to Nabang.

It is said that, in the case of Nabang and Lazai, China achieved a mutual agreement with the KIO that the displaced Kachins should be kept on the Myanmar side. China had promised to the KIO that China would let displaced Kachins in when Laiza is seriously threatened by the Burmese army. Since Laiza is the headquarters of the KIO, it had been well defended and had not been severely attacked by the Burmese army. It is perhaps why the displaced Kachins were willing to stay in Laiza where they were taken care of by the KIO rather than going to China where they would receive no support from the Chinese authorities and the living cost is much higher. ${ }^{620}$ If China's promise to the KIO was sincere, it probably echoes China's strategy in the Kokang incident. China is said to have been receptive to the Kokangs because the Kokang army was completely defeated by the Burmese army. If Laiza falls, chances are the KIO is completely defeated; only in that situation would China open its door to the displaced Kachins. As long as Laiza is under the KIO's control, there is no way to tell whether China will keep its promise or not. Yet, it shows again that it was not the refugee criteria but rather political considerations that were decisive in China's receptivity towards the displaced Kachins.

Zhangfeng is a much larger town than Nabang and used to be a prominent gateway between China and the British colony of Burma. Zhangfeng town is divided into several smaller areas. The official border crossing point is in Laying area and thus known as Laying Passage. Laying camps mentioned by Kachin participants (see sec III) were located in Laying area in Zhangfeng. In Zhangfeng, the Chinese-Myanmar border is at many parts mere an invisible line going right through agricultural fields and is very close to residential areas. There are many unofficial crossings and pathways along the border. It is a semi-open business for local motor bike drivers to bring people across the border via unofficial pathways. It is somehow ironic that at some of these unofficial pathways, local villagers set up their "unofficial" checkpoint with a bamboo pole to charge a small amount of "crossing fees".

A substantial proportion of the displaced Kachins repatriated in August 2012 from Laying were accommodated in camps at Ma Ja Yang. Although attacks from the Myanmar government army resumed soon after the repatriation and Mai Ja Yang was heavily shelled in January 2013, there has been no report of large scale cross-border movement from Mai Ja Yang area to Zhangfeng.

The situation in Nabang and Zhangfeng showed that border control was not tight in mid-April 2013. It seemed that the flow of the displaced Kachins was, to some extent, controlled by both sides. By achieving a mutual agreement with the KIA to keep most of the displaced Kachins on the Myanmar side of the border and tolerating a certain degree of freedom of border-crossing,

${ }^{620}$ KIO provides rice and basic health services to the IDPs. 
China has avoided the dilemma of how to balance its legal and humanitarian responsibilities to the displaced Kachins and its need to maintain good relations with the Myanmar government to protect Chinese investments in Myanmar.

\section{Voices from Refugees and Humanitarian Workers \\ A Absence of Assessment of Individual Situations}

Participants confirmed that, as far as they knew, Chinese authorities did not conduct individual interviews or collect detailed individual information of the displaced persons in the case of the Vietnamese refugees, the Kachins, or North Koreans. The Vietnamese and Kachin participants said that there was, however, some form of registration, where basic information of the incomers, such as hometown and occupation, was collected by Chinese authorities.

\section{$1 \quad$ Vietnamese}

The Vietnamese participant said that upon arrival at Dongxing town, Guangxi Zhuang Autonomous Region, China, which was a main entry point for the refugees from Vietnam between 1978 and 1982, refugees registered with the Dongxing local authority:

Right! We registered. Collectively. We told them where we came from.

However, due to the quick arrival rate and the large number of the incomers, it was impossible to investigate the situation of all incomers one by one:

They asked some people [for more details], but not everyone. The local residents in Dongxing had vouched for many people [refugees from Vietnam] ${ }^{621}$ They [Chinese officials] did not have enough time to ask every person. There were too many people.

\section{$2 \quad$ North Koreans}

In the case of the North Koreans, a humanitarian worker interviewed, who worked with North Korean escapees, said that the Chinese authorities usually did basic investigations with North Koreans caught to obtain their identify information, although he was not sure whether the Chinese authorities kept a record of such information. For obvious reasons, the two North Korean participants avoided contact with Chinese authorities.

\section{$3 \quad$ Kachins}

The Kachin participants admitted that basic information of the displaced Kachins living in the self-established camps, including name, age, gender, home village, and the total number of people living in the camp, was submitted to Chinese authorities. There were different accounts of how and why the information was collected. According to one participant who stayed in a

\footnotetext{
${ }^{621}$ Many ethnic Chinese living in Vietnam originally emigrated from Guangxi and had relatives and friends in Guangxi.
} 
camp in Laying town, the information was gathered and submitted to the local Chinese public security bureau by the village headmen at the camp:

The headman of each village wrote down ... our names, gender and age and handed it [the information collected] to the local public security bureau.

She saw it as both a custom and an attempt to obtain the local authorities approval of their stay:

On the one hand, in Myanmar when people have guests [from outside the village], they have to register the guests with village head. With that in mind, we registered with the local public security bureau when we were in Laying. It was a voluntary act, not a requirement from the local public security bureau. On the other hand, it was part of our attempt to apply for their approval of letting us remain at the refugee camps.

Another Kachin participant, who also stayed in a camp in Laying town, ${ }^{622}$ recalled that Chinese officials came to the camp at least four times to collect information about residents at the camp:

They [the Chinese officials] collect like gender, male or female. ... They just come [to the camp] and take the record and detail in the compound. ... At least I remember, four times. They are like checking, these people are still staying in this camp or where did it go.

She said that the information was required by two local Chinese government bodies:

Police and another administration department. ... Administration just means they are township, regional administration department.

A third Kachin participant mentioned that Chinese officials also checked their room and tried to obtain information of organisations supporting the Kachins:

When the police come, they investigate everywhere. Every room. And when they saw even rice bag, who support you? Which organisation come and support you? They ask this kind of question.

However, a Kachin participant who was previously in a camp in Nongdao town said that Chinese officials did not register her information:

${ }^{622}$ There were four unofficial refugee camps in Laying. See below interviews with humanitarian workers. 
No, they did not register my name. Government officials only came to take photos when the houses [shelters] were built.

Two aid workers interviewed, who worked with the displaced Kachins in China, were aware that basic information of the displaced Kachins living in camps was submitted to the Chinese authorities. According to one of them, the data was required by the Chinese authorities:

They asked the information, the data, the people, names, age, how many people, they asked to the camp committee and they gave. ${ }^{623}$

The other one held that the requirement for residents of Myanmar to register with local Chinese authorities after their entry into China had existed before the conflict:

It is a long-established practice. ... Most border residents ... normally follow that practice, because according to the Chinese government's provisions, they would provide this information to register with the local [authorities].

Indeed, according to arts 11, 12 and 13 of the 1990 Yunnan Province Administrative Rules for Entry-Exit of Foreign Border Residents in Chinese-Myanmar Border Areas, ${ }^{624}$ border residents from Myanmar are required to register with Chinese public security authorities if they want to stay in China overnight or longer.

B Reasons for fleeing

All Category I participants were asked why they went to China.

\section{$1 \quad$ Vietnamese}

The Vietnamese participant said that she was forced to leave by the Vietnamese authorities:

I was born in Vietnam and grew up in China. My family had lived in Vietnam for four generations. Despite this, I was marginalised in Vietnam. The Vietnamese government had summoned me to the police station in 1977. They asked me why I lived in Vietnam. Not only us. All huaqiao, ${ }^{625}$ even those with a passport. ${ }^{66}$

\footnotetext{
${ }^{623}$ The camp committee is a self-governance team formed by the displaced Kachins at the camp.

624 See chapter III.

${ }^{625}$ The term huaqiao is legally defined as Chinese nationals settled overseas, but may not necessarily be used in the strict legal sense in a casual context, see above $n$ 482. From the context of this interview with the Vietnamese refugee, it is clear that she referred to person with Chinese nationality who settled in Vietnam.

${ }^{626}$ A passport probaly was not required by either China or Vietnam for Chinese or Vietnamese citizens travelling between the two countries for many years. A special arrangement in 1955 betwwen China and Vietnam allowed citizens of each country to travel across the border with a number of documents other than passport, Guangxi Local Chronicles Editorial Committee Guangxi tongzhi - waishi zhi [Guangxi Local Chronicles - Foreign Affairs Chronicles] (online ed 1996) Guangxi Local Information Web $<\mathrm{http}: / /$ www.gxdqw.com/bin/mse.exe?seachword=\&K=a\&A=25\&rec=16\&run=13> (accessed 18 February 2013).
} 
Her response illustrates the complex nationality issue of the ethnic Chinese fleeing to China during the Indochinese refugee crisis. She said:

I was huaqiao. Vietnam marginalised huaqiao. Vietnam wanted us to take Vietnamese nationality.

Later in the interview, she brought the issue up again:

In 1966, they [the Vietnamese authorities] forced all of us to take Vietnamese nationality. Local [Chinese] intellectuals stood up. They were heroes. huaqiao went on the streets to demonstrate. They said: "No Vietnamese nationalities! Huaqiao is huaqiao!"

When asked if she would be allowed to stay in Vietnam if she was willing to take Vietnamese nationality, she exclaimed in protest:

I would not take [Vietnamese nationality]!

She also recalled:

China issued passport. There were witnesses and other certificates. Real passport! [Vietnam] still charged us of [illegally] crossing the border and being spies. Why?

This appears to confirm that Vietnam was still not authorised to issue regular passports to the ethnic Chinese in Vietnam prior to the exodus. ${ }^{627}$

\section{$2 \quad$ North Koreans}

Both North Korean participants said they left North Korea for China mainly to meet family members who had escaped to China before them. Both crossed the border as minors without the company of adults. For example, one of them said:

[I went to China] to unite with my mother. She had been in China for a few years. My uncle is a Chinese citizen in China.

She added that her mother left North Korea for "economic freedom".

The other North Korean gave similar reasons for her departure from North Korea:

${ }^{627}$ See Chang above n 470, at 197; chapter IV.I.A The Crisis and China's Response. 
For family reasons. My stepfather's sibling is a Chinese citizen and was living in China. I went to Chinese to meet my family. Life was very difficult in North Korea. I left North Korea alone for China.

Their experience illustrates that there are close connections (in their cases, family ties) between North Koreans and China, which is usually considered as one of the "pull factors" for North Koreans to China, and that economic hardship was one of the push factors for North Korean escapees. Their experience also indicates that unaccompanied minors may not be an exceptional or rare phenomenon in the situation of the North Korean escapees. The situation of unaccompanied North Korean minors demands urgent attention and humanitarian response.

\section{$3 \quad$ Kachins}

Attributing their departure to the armed conflict between the Myanmar government troops and the KIA, the Kachin participants commonly highlighted their fear of Burmese soldiers:

I was afraid if we are staying in the village or in this [Kachin State] side, if they find, if the Burmese soldier found me or us, they will hit or, hit us, or ask many question or, instead, in case, I could die, instead. One day, when they push the Burmese frontline, then I decided I would be more suitable to cross to China side and stay in the China side. (Kachin participant A)

Our village was close to the Burmese controlled area. We heard that the Burmese soldiers were evil, like the Japanese. We were scared when we heard that Burmese soldiers were coming, therefore, we fled to Laying. When we arrived in Laying, we felt that we were no longer in danger. We felt relieved. (Kachin participant B)

Burmese soldiers, when they meet with women, they rape; and when they meet with men, hit them and even sometime kill. That is why I am afraid of this kind of situation. That is why I left my village and enter into the China side. (Kachin participant $\mathrm{C}$ )

The response of the Kachin participants clearly illustrates the inter-ethnic group tension between the Burmese, who control the central government and government army, and the ethnic Kachins. They demonstrated a unmistakable fear of the "coming of Burmese soldiers", rather than merely a fear of gunfire. Description of harsh treatment by the Burmese-controlled Myanmar government also came abundantly from the ethnic Kachins I met in Laiza and Mai Ja Yang.

C Unavailability of Refugee Status Determination Services for North Koreans and Kachins

Responses of the North Korean and Kachin participants illustrate that RSD procedures were generally not available for the North Korean escapees and the displaced Kachins in China.

\section{$1 \quad$ North Koreans}

One North Korean participant said she heard "nothing" about applying for refugee status in China. The other North Korean participant believed that China did not accept refugees: 
I know [the word "refugee"]. Refugees are given a status. I did not hear anything about applying for refugee status in China. I only heard that China did not accept [refugees]. Therefore, we bought our fake identity papers.

They did not hear of UNHCR in China either. One of them asked:

Is that [UNHCR] an embassy? ... That [UNHCR] I did not heard of, really. I only heard that there was South Korean embassy in Beijing. If one gets in there, one can go directly to South Korea. But it would be very dangerous. I do not like taking risk.

\section{Kachins}

Most of the Kachin participants said that they did not apply for refugee status or any other legal status in China or had never heard of refugee status. One mentioned that she was warned by the Chinese border securities not to claim to be a refugee:

No[, I did not apply for refugee status]. At the border, the Chinese border authorities did not allowed us to admit that we were refugees. We were afraid to say the word "refugee".

One asserted that people at her camp did not apply to the Chinese authorities for a legal status because they thought it was obvious that the Chinese authorities did not want them to stay anyway:

It seems, they [the Chinese authorities] do not want to, they do not want [us] to legally stay. They do not want to allow, in my point of view. When I was staying in Laying, many authority come, many reason, and they push, many times they push to return back.

Another one did not know about refugee status:

As for me, I do not know about that refugee status, ... But I do not know, I do not know about the refugee status when we are, while we are staying in the Laying camp.

She and other displaced Kachins at the camp, however, did try to optimise their chance to stay in China by cleaning up the camp, after knowing that sanitation at the camp was a concern to the local Chinese officials: 
[I]f we are dirty, our environment, then, if we do like these bad habits, the authority they do not want [us] to stay. So we will try as good as we can, clean the environment, we do by themselves, without any person pushing us.

Notably, one Kachin participant said the displaced Kachins at her camp tried to obtain refugee status through the local Laying police station:

We made an attempt to obtain a status. We had little money, but we put our money together to buy gifts and went to the police station to apply for refugee status.

Judging from her description, what they did probably was more like a plea or negotiation for approval for their stay than an application for a legitimate status. No assessment or investigation was consequently carried out by the police who did not take their gift and dismissively told them higher authorities had instructed them to return to their home country:

They did not accept and told us "the above" ordered us to go back to Myanmar.

None of the Kachin participants knew about the office of UNHCR in China. For example, one Kachin participant said:

No[, I did not hear of the UNHCR in China]. We heard that the Chinese government denied the existence of the refugees after refugees entered China.

Another Kachin participant, when asked if she tried to contact UNHCR in China, replied:

I have never heard about it.

Aid workers interviewed also confirmed that Kachin community leaders negotiated with the local Chinese authorities to enable the displaced Kachins to stay in China longer. One aid worker mentioned that a friend of hers working in a camp wrote a letter to the local Chinese government to ask for their approval of the stay of the displaced Kachins: 
They have been try to write, how you call that, letter to local authority to let them to stay at that time they have to leave, forced to leave. Before they are forced to leave, they also write a letter to local government.

Another aid worker believed that leaders among the displaced Kachins had tried to obtain a legal status or a status whatsoever approved by the Chinese authorities:

One core member of the camp committee said to me at that time that the [Chinese] government was driving them out and they were negotiating with the local government. Therefore, I think this to some extent demonstrates that they made an effort.

He also indicated that if the Kachin leaders did not work to gain approval from the Chinese authorities, many Kachins would not have been able to force their way into China against armed Chinese border securities or to stay in China for more than a year. He further offered his insight as to why China denied the existence of "Kachin refugees" on its territory:

If China admits the existence of refugees, it will have to shoulder the moral and humanitarian responsibilities to the refugees. ... In that case, the investments of both parties will be affected. Chinese investment in Myanmar is rather sizable. ... Probably there are many complicated factors in this situation. There was no way to actually achieve [an agreement].

At the same time, however, he expressed his doubt on how informed Beijing might have been of what had been happening on the Chinese-Myanmar border:

I am not sure, whether [Beijing] really did not know or because of this kind of, because, you know, it is really difficult to know what actually happened if a person does not come here.

Indeed, unlike in 2009 during the Kokang Incident, no officials were sent from Beijing to Yunnan Province to lead the work of handling the incoming displaced Kachins.

\section{Legal Basis for China's Treatment of Displaced Kachins}

Kachin participants had different experiences at the Myanmar-Chinese border in the course of their escape to China. Generally, their experiences illustrate that those who had the so-called "passport" (a travel document issued by Myanmar immigration offices along the MyanmarChinese border) were allowed to enter China with no problem at any time. Those who did not have a "passport" were sometimes denied entry, but it appears that, although China tightened up security along the Yunnan-Kachin border, it did not enforce a strict no-entry policy on those without a proper entry document during the Kachin influx. 
For example, a Kachin participant, who had a "passport" and fled to Nongdao town, China in July 2011, reported that she was allowed to cross the border by Chinese border securities but those without a "passport" and taking a lot of things with them were pushed back:

Some people had passport. Those from the mountains did not have passport. They were questioned. Some of them were pushed back but others were allowed to enter. If one brought a lot of things, [the Chinese border securities] asked the person to go back.

She added that:

They only asked us if there was war at our home town. We said there was war. But the Chinese border security blocked the border. They said if the war became worse, they would let everyone in. They said many people did not need to entered China now and they drove them back. They did not really give reasons. They just did not let them in. After the war broke out, the border control was really tightened by the Chinese border authorities.

A Kachin participant, who fled to China in mid-June 2011 with her baby, said that she and her fellow fleeing villagers did not have a "passport" and that they were initially barred from crossing the border:

There were many people at the border area. The Chinese border security does not allow to enter many people because they do not have, no passport.

While no one else was allowed in on that day, she and another woman, who also had a baby with her, were later waved in by a Chinese border security officer:

Just wave. Just waving. I and a friend of mine, also the baby. ... I think the police, one of the police is like a little bit young, and he hear the baby was crying. This police just called me like this [waving].

Two other Kachin participants, neither of who had a "passport", had a more curious experience. They, along with many other displaced Kachins, pushed against Chinese securities, who tried to prevent them from crossing, and forced their way into China. One of them escaped with fellow villagers from their village in the mountains to the Chinese border near Laying town around mid-June 2011: 
Many people rushed to the border from the mountain villages when they hear the gunfires. Some escaped with nothing except the clothes they were wearing. Others came by motorbike, four or five people on one motorbike. ... We were really frightened. The Chinese border securities asked us not to enter China. We desperately pushed our way through across the border. ... The Chinese border securities were not able to stop us.

She estimated that there were several hundred people with her at the border at that time: ${ }^{628}$

Several hundred at a time. Totally more than 3,000 people crossed to Laying.

The other one entered China near Nongdao town in April 2012:

On the bridge, there is many [Chinese] police are waiting. These policemen are waiting, not allow to cross. The people, even though the policemen are waiting and not allow to cross, but they are trying, pushing. ... Chinese policemen are also pushing, the IDP [displaced Kachins] also pushing, and they are enter.

They said that after they pushed their way into China, they did not have difficulty in going further from the border area to the camp in Laying and Nongdao.

Two other Kachin participants, who crossed into China in June and November 2011 respectively, voluntarily described how they avoided the Chinese border checkpoints to enter China via "unofficial" paths:

On that day, there are many people, many IDP [displace Kachins], coming down, want to flee to the China side. Same situation, many policemen, many soldier, are waiting around the border area. He is hiding, waiting in the bush. I was hiding and cross that bush. And entered Laying. (Kachin participant D)

I was the, like, division, like, hiding with too, close the border, I need to rent a motorbike or I had to pay 150 Yuan on that day. Although I illegally crossing. (Kachin participant E)

The experiences of the Kachin participants indicates that the 1997 Chinese-Myanmar bilateral protocol and the 1990 Yunnan Entry-Exit Rules for of Foreign Border Residents in ChineseMyanmar Border Areas are likely to have served as the legal basis for China's treatment of the displaced Kachins. As mentioned in chapter III, art 20(2) of the 1997 Chinese-Myanmar bilateral

\footnotetext{
${ }^{628}$ It is perhaps not unusual that fear and desperation drove the whole village to flee together during the conflict in Kachin state. I heard similar stories from people internally displaced in camps in Laiza, Kachin State.
} 
agreement allows border residents of either party to the agreement to cross the border with a border pass at designated crossings, exempting them from a normal visa. The 1990 Yunnan Entry-Exit Rules allow holders of the "exit-entry pass for foreign border residents" to enter and stay in Yunnan for from 15 days to up to two years (including extension). ${ }^{629}$

Kachin participants, as well as aid workers supporting displaced Kachins in China, confirmed that the so-call "passport", obtained from Myanmar immigration office along the border, normally enables them to enter and stay up to seven days in China without a visa:

[The border pass] enables us to stay in China for up to seven days per entry. After seven days, we had to go back. We went back and forth. (participant F)

We hold border pass document, you know, the one that like this. People from Burma have to hold temporary pass, border pass document. We crossed with this, no problem. ... We got seven days, like a visa, you know. We got seven days to stay in China. After seven days, we can, we should leave China. (participant G)

Article 20(2) of the 1997 Chinese-Myanmar bilateral agreement also specifies that the border pass is valid for travel within border areas agreed on by both parties and that holders of the border pass is allowed to take with them persons under 16 years of age as long as the number of persons they are taking as well as their name and age are specified on the border pass. Kachin participants reported that each holder of the border pass was able to take one person without a border pass, regardless of age, with him or her until the conflict broke out in June 2011:

Previously, the holder of a border pass was allowed to bring an extra person. At that time [during the Kachin influx], the holder were allowed to enter but not allowed to bring an extra person.

In light of the above, it is likely that China admitted the displaced Kachins according to with the 1997 Chinese-Myanmar bilateral agreement and the 1990 Yunnan Exit-Entry Rules, although China's current practice seems to be slightly different from the provisions of the two documents.

It should be pointed out that, in the absence of relevant bilateral arrangements and national legal provisions, China's admission of displaced Kachins who did not hold a border pass is a plausible effort to respond to the urgent protection needs of the displaced in the situation of mass influx.

\section{E Lack of Assistance from Chinese Authorities}

The Kachin participants confirmed that there was very limited or no assistance from the Chinese government. For example, one participant who stayed in Nongdao town recalled that a medical team visited the camp once in April or May 2012:

${ }^{629}$ Article 6. See above n 419. 
When I was staying in the Nongdao camp, I get, I remember, some medical treatment team come and they do medical treatment. I remember only one time.

Another participant who stayed in Laying town said that medical treatment was provided around June or July 2012 shortly before their repatriation in August 2012:

When the children or women also some people get the disease, a disease, or some skin disorder, skin disorder that time, three day, two day, get medical treatment, after that they had to return back.

Two participants' family members were treated for skin disorder:

In my family, my grandson, only their grandson. Skin disorder and he get medical treatment.

My children, like, young two, very young, very young two, around 14, boy, just skin disorder, they get medical treatment.

One Kachin participant was of the opinion that the Chinese authorities used the medical treatment as part of their tactic to kick out the displaced Kachins at the camp. Her opinion seems to coincide with another participant who said that there was no assistance from the Chinese government:

They [the Chinese authorities] also came when there was disease, for example malaria or severe illness [at the camp]. Their purpose was to take that chance to push us back.

It should be pointed out that the Kachin participants who denied having received any help from the Chinese government often emphasised their gratitude for the assistance from the Chinese civilian society. One participant who stayed at a camp in Nongdao town said:

No government assistance. I have never heard of that. There were kind Chinese residents and charity groups [who helped us]. The strongest support came from the brothers and sisters of our church.

Another participant who stayed at a camp in Laying said: 
No government assistance. The brothers and sisters from our church helped us. The World Health Organisation as well.

Instead, she added, the Chinese authorities intervened in their setting up of the shelters:

The Chinese border authorities asked us not to build [shelters]. We first lived in a warehouse owned by a timber businessman. Later, we went to Laying's rubbish dumping ground, cleaned it and built tents.

Aid workers working with the displaced Kachins confirmed that there was some but very limited assistance from the local Chinese authorities. For example, an aid worker from Myanmar mentioned that the health departments of Ruili City and Longchuan County provided vaccinations to the displaced Kachins in Nongdao and Laying respectively:

I know they [the displaced Kachins in Nongdao] got health assistance, health care. Like vaccine from Ruili health department. ... Laying camp they also got the vaccine ... from Longchuan.

Yet, she saw the assistance more as a result of China's fear for disease spreading from the displaced Kachins than genuine willingness to help the displaced. She laughed politely and gently:

Maybe it is because they [Chinese authorities] were afraid of, just to prevent, prevention of the diseases.

Obviously, she, to some extent, shared the view of some of the Category I Kachin participants who, as mentioned above, regarded the medical assistance from the Chinese authorities as part of China's effort to push away unwanted guests.

A Chinese independent humanitarian worker, however, offered a different interpretation of China's treatment of the displaced Kachins. He agreed that China's limited assistance was largely health-related:

Within their jurisdiction, they [local authorities] sent health workers to sanitize [the camps], or prevent epidemics. In addition, some village clinics also provided relevant medical services for the refugees from Myanmar. 
Additionally, he mentioned police service as a form of assistance provided by the local government:

A small portion of the services [provided to the Kachins by the Chinese authorities], of course, included local police service. Their work in maintaining the public security is crucial, because the location [of the camps] is on the border, very sensitive.

However, he emphasised the humanitarian characteristics of China's assistance:

I think the Chinese government shouldered some responsibilities from humanitarian aspect. ... After all, the Chinese government provided some help unofficially. ... It just did not do it too obviously, but did provide some assistance.

He believed that the Chinese government opted to remain low key and not to officially assist the displaced Kachins in order to protect China's economic interest in Myanmar:

It really has no other ways to deal with the government of Myanmar, because the government of Myanmar is actually controlled by the military authorities. ... China and Myanmar has, the government has many business projects [in Myanmar].

\section{F $\quad$ Repatriation of the Displaced Kachins}

Accoridng to the Kachins interviewed, Chinese authorities had persistently persuaded them to return to Myanmar prior to their repatriation in August and September 2012.

For example, a participant previously in Nongdao town recalled that Chinese officers used to come to the camp almost every day:

They came to negotiate with us and told us that we were given one year [and that] we would be kicked out after one year. They came almost every day at that time.

Another participant previously at Laying recalled that during her six-month stay at the camp, Chinese officers visited the camp eight to ten times:

I remember nearly ten time, eight time, authority come and [said] why are you staying until now? 
According to the participants, two main reasons used by the Chinese officers to persuade them to return Myanmar were: (1) there was no more fighting in Kachin State, and (2) residents at the camp would spread diseases to Chinese civilians:

The reason, the main reason is right now fighting is stopped. Go back. Go back. Another one is that you are like living in a compound, very crowded, very crowded and the environment is dirty. So in case some disease or some virus spread, we are afraid, we are afraid to spread into our civilian. So that is why you must return back. That is the one reason. (participant $\mathrm{H}$ )

They said, you Myanmar have such and such disease and have brought [in China] such and such disease. (participant I)

Several Chinese authorities, including the Chinese border securities, the police, and the local municipal government, were involved:

Yes, they came. Not only border securities. Some from Mangshi city. We did not know exactly where they all were from. Many departments. ... We just say those people were from "the above". (participant J)

Mostly regional administration and sometime police. (participant K)

Most Kachin participants confirmed that many of the displaced Kachins in the self-established camps were forcibly repatriated in August and September 2012:

When we were pushed back, we left with our heart filled with sadness. During the process, at 6 in the morning, more than 100 border securities and police. Several trucks were also came. Some people were cooking. There were children. The Chinese police torn down the house and drove us out like cattle. We came back with great sadness.

In the end, we who remained in China were kicked out. They [the Chinese authorities] tore down our houses [shelters] and burned them down.

One Kachin participant, who stayed in a camp in Laying town, said he returned to Myanmar voluntarily:

As for me, I want, do not want to stay longer in Laying, China side. That is why [when officials went] check, who, now, who like to come, return back, I mentioned my name. 
An aid worker interviewed believed that the Chinese government had asked for coorporation from the KIO to persuade the Kachins to return home:

Some says from the Yunnan government officially announced, officially tell to the Kachin local authority, "Hey call your people." But they are not ready. At that time, the local Kachin leader was not ready, not prepared for the IDP/refugee to stay at the camp. Since that time, they forced many times, the Chinese government forced the refugees to return to this side.

Another aid worker mentioned that the intervention from the higher level of the Chinese government might have significantly contributed to the abrupt repatriation of the displaced Kachins in August and September 2012:

I understand that some local authorities of nearby border towns were handling it for a few months. However, due to the growing number of the displaced persons and political concerns, the handling [of the displaced Kachins] was centralised later on, hence the more rigid attitude and repatriation.

\section{G Blurred Identity of Indochinese Refugees in China}

The Vietnamese participant referred to herself as huaqiao most of the time and as refugee only twice during the 45 minute long interview. She emphasised several times that she, as well as "tens of thousands" of people whom she fled with from Vietnam had Chinese nationality.

She recalled that she and her family, along with many others fleeing from Vietnam to China, were received by officers from overseas Chinese affairs organisations:

[We were received by] huqiao organisations. They were awaiting us. Once we crossed the border, they met with us.

When asked why they were called refugees nowadays, she paused, looking confused, and said hesitantly that:

They [the Vietnamese authorities] expelled us.

When asked if she knew the ORSIRs, she again looked puzzled and was hesitant:

Indochinese? It [Vietnam] was French Indochinese. Then it is us, the huaqiao. I think so. But I only know, [pause] there was no such a name at that time. 
The response of the Vietnamese participant appears to confirm that the Vietnamese refugees were initially received as returning Chinese nationals and that they are, as mentioned in chapter IV ${ }^{630}$ probably still regarded by the Chinese government as Chinese nationals for domestic purpose.

\section{Conclusion}

The voices of the participants are a strong cry for meaningful and humanitarian protection as well as clear and regulated criteria for refugee status and predictable and fair RSD procedures in China, in particular criteria and procedures suitable for mass influx situations. The experience of the Kachin and North Korean participants illustrates that the protection needs of some persons, who may well qualify for refugee status under the Convention and Protocol, are left unmet as a result of China's current policy.

China mainly relied on the 1997 Chinese-Myanmar bilateral protocol and the 1990 Yunnan Entry-Exit Rules for of Foreign Border Residents in Chinese-Myanmar Border Areas to respond to the displaced Kachins entering China. Nevertheless, China's tolerance of the entry and stay of the displaced Kachins not covered by these two documents reflects the growing willingness of Chinese authorities to deal with refugees and other displaced foreigners in a less restrictive and more humanitarian manner.

The status quo of the border towns I visited illustrates the fluidity along the Chinese-Myanmar border. Border crossing has long been accepted by the local people, and probably also by the local authorities, as a normal practice in everyday life. This acceptance to a large extent explains China's relatively tolerant stance on the displaced Kachins.

${ }^{630}$ See above n 500 . 


\section{Conclusion}

China is in an opportune position to further enhance refugee protection in China and play a leading role in the region.

- Veerapong Vongvarotai, former UNHCR Regional Representative for China \& Mongolia ${ }^{631}$

\section{Chinese Refugee Law and Policy at a Crossroad}

China is at a critical juncture in advancing its refugee law and policy. On the one hand, the rapidly increasing number of displaced foreigners calls for predictable, regulated responses. On the other hand, China has clearly demonstrated a growing interest in addressing the refugee issue within a more formalised framework.

In the present situation, Chinese law falls short of providing a sufficient legal framework for assessing refugee claims and safeguarding the principles of non-refoulement and nonpenalisation. First, there is a gap between the criteria for asylum contained in art 32 of the 1982 Chinese Constitution and the criteria for refugee status contained in the Convention Refugee Definition. Second, Chinese law in general contains very few provisions which distinguish refugees from other migrants. Third, as the provisions of the Convention and Protocol have not been incorporated into Chinese law, the Chinese legal system cannot provide effective implementation of the provisions of the Convention and Protocol, which themselves are known for the limitations in their supervision mechanisms and the lack of refugee status determination procedures.

Traditionally, the Chinese government has associated the concept of asylum mainly with political concerns. In general, it has perceived refugees as a threat to social stability and national security. Such perception essentially is rooted in the mistrust of foreigners by the Chinese government since 1949. It is also because China's experience with refugees and other displaced foreigners is characterised by large-scale inflows from neighbours.

The scale of the inflows is a key factor affecting the Chinese government's response to displaced foreigners entering China. China's current policy on refugee status determination, in effect, distinguishes between displaced foreigners who are part of a large-scale inflow and those who are not. While the latter are allowed to access RSD procedures administered by UNHCR, the former depend on the policy decisions of the Chinese government.

In mass influx situations where the Chinese government determines the status of the displaced foreigners concerned, the security, political, and strategic interests of China have overshadowed the commitment of China under relevant international treaties. The relations between the Chinese government and the ruling authorities in the place of origin of the displaced foreigners have usually been an important consideration in this regard. The Chinese government has also

${ }^{631}$ Veerapong Vongvarotai "Forward" in Liang, above n 32, at 2. 
favoured bilateral agreements with the place of origin of the displaced foreigners over multilateral treaties. As a result, the protection needs of some displaced foreigners, who may well qualify as refugees under the Convention and Protocol, have been left unmet.

The displaced foreigners' ethnic and cultural links with the majority Chinese population are likely to have been another key factor affecting China's receptivity towards displaced foreigners. A likely explanation is that the Chinese government probably considers foreigners who have strong ethnic and cultural links with China as a lesser threat to social stability, which is a top priority of the Chinese government.

Generally speaking, China has been cautious about recognising displaced foreigners as refugees. Non-recognition of refugee status does not necessarily exclude protection by the Chinese government. On the other hand, refugee status in China does not entail the full range of rights afforded by the Convention and Protocol or entitlement to the same rights among persons with refugee status.

China has not involved itself to substantial and constructive conversation on refugee recognition issues with the international community. However, China has demonstrated a growing interest in engaging in the international refugee protection regime, especially at the regional level, in recent years. As China's engagement in the international refugee protection regime deepens, it will have more dialogue and greater cooperation with the key stakeholders in the regime. It is inevitable that China's conception of refugees will evolve through these dialogues and cooperation.

Essentially, the advances of Chinese law and policy on refugee status are part of, and depend on, the broader processes China is going through as it emerges as a world power. These processes include the strengthening of the rule of law, its gradual, inevitable, and sometimes painful integration with the international human rights system, and the evolution of China's perception of "self" and "others" in the era of globalisation. As China is vigorously working towards the better rule of law, the improvement of human rights, and a harmonious and tolerant society, there are reasons to believe that a predictable and fair national mechanism for refugee status determination is in line with China's interest.

\section{Towards a Predictable and Fair National Mechanism}

In the past few years, China has made progress in formalising its protection for refugees and asylum seekers through legislation. In particular, the national refugee regulation that is being drafted will, when passed, undoubtedly have a profound and positive impact on refugee status recognition in China.

The recommendation in this thesis is that China pass the draft national refugee regulation as soon as possible. The national refugee regulation needs to provide a definition of a refugee. That definition must be in accordance with the Convention Refugee Definition. In establishing the definition, consideration should be given to the humanitarian response needed in mass influx 
situations and, ideally, also to regional instruments relating to refugees such as the Bangkok Principles.

Further, the national regulation needs to include clear and fair RSD procedures, which specify the authorities responsible for processing applications for refugee status, set out a reasonable time frame for responses and decision making, and include review or appeal mechanisms. In particular, the RSD procedures to be established by the national refugee regulation should contain mechanisms - usually group determination on a prima facie basis - suitable for RSD in mass influx situations. Applicants should have access to legal assistance and should be given reasons for the decision on their status.

Establishing a predictable and fair mechanism for refugee status determination would be the first step, not the last, for China to enhance refugee protection. A RSD mechanism, however welldesigned, is not a guaranteed solution for all issues relating to forced cross-border displacement for any country. The main challenge for China in determining refugee status, as for many other countries, is to find a balance between its international legal obligations and the State interest.

China's political will to accept and protect refugees and China's economic capacity to accommodate the protection needs of refugees are two decisive factors of Chinese refugee law and policy. As reforms in China continue to yield remarkable achievements, there is every reason to be confident that China's political will and economic capacity to accept and protect refugees on its territory will increase in the years to come. 


\section{BIBLIOGRAPHY}

\section{A Cases}

\section{New Zealand}

Zaoui NZRSAA Refugee Appeal No 74540, 1 August 2003.

$S$ v. Chief Executive of the Department of Labour [2007] NZCA 182.

\section{Australia}

Ozmanian v MIMA [1997] FCA 256.

Lay Kon Tji v. Minister for Immigration \& Ethnic Affairs [1998] FCA1380.

Minister for Immigration and Multicultural Affairs v Khawar [2002] HCA 14.

3 Canada

Vahe Salibian v Canada (Minister for Employment and Immigration) (1990) 3 FC 250.

Rizkallah v Canada (Minister for Employment and Immigration) (1992) 156 NR 1.

Ward v Canada (Attorney General) (1993) 2 SCR 689.

Hersi v Canada (Minister for Employment and Immigration) (1993) FTR 226.

Chan v Canada (Ministry of Employment and Immigration) (1995) 3 SCR 593.

Win v. Canada (Ministry of Citizenship and Immigration) 2008 FC 398.

4 Germany

W9 K 92.30416 446.11 Ger VG Würzburg [German Administrative Court, Würzburg], 5 March 1994.

5 South Korea

Young Soon Lee SC 96 Nu 1221, 12 November 1996.

6 United Kingdom

Horvath v Secretary of State for the Home Department [2001] 1 AC 489 (HL). 
$R v$ Secretary of State for the Home Department; Ex parte Adan [2001] 2 AC 477 (HL).

KK and ors (Nationality: North Korea) Korea CG [2011] UT 92 (IAC).

GP and others (South Korean citizenship) North Korea CG [2014] UT 00391 (IAC).

\section{B Legislation}

1 New Zealand

Immigration Act 2009.

2 Australia

Immigration Act 1958.

\section{China}

Household Registration Regulations 1958.

Regulations on the Administration of Entry, Exit, Transit, Residence and Travel of Aliens in China 1964.

Nationality Law 1980.

Constitution 1982.

Law on Administration of Entry and Exit of Chinese Citizens 1985.

Law on Administration of Entry and Exit of Border by Foreigners 1985.

Law on Protection of the Rights and Interest of Returned Overseas Chinese and Their Family Members 1990.

Yunnan Province Administrative Rules for Entry-Exit of Foreign Border Residents in ChineseMyanmar Border Areas in 1990.

Law on Protection of the Interests of Women and Children 1992.

Ministry of Public Security Notice on Taking Legal Actions Against Illegal Entry and Illegal Stay of Aliens 1992.

Regulations on Management of Employment of Foreigners in China 1996. 
Identity Card Administration Law 2003.

Administrative Rules on Approval of Permanent Residence of Foreigners in China 2004.

National Emergency Plan on Sudden Incidents Involving Foreign Factors 2005.

Passport Law 2006.

Yunnan Province Wenshan Prefecture Emergency Response Plan on Sudden Incidents Involving Foreign Factors 2006.

Yunnan Province Office of Lushui County People's Government Notice on Circulation of Lushui County Emergency Response Plan on Sudden Incidents Involving Foreign Factors 2007.

Yunnan Province Nujiang Prefecture Emergency Response Plan on Sudden Incidents Involving Foreign Factors 2007.

Ministry of Finance Interim Implementation Rules for Management of State-owned Assets by Institutes Functioning Abroad 2007.

Mengla County Emergency Response Plan on Sudden Incidents Involving Foreign Factors 2008.

Shigatse Prefecture Emergency Response Plan on Sudden Incidents 2008.

Exit and Entry Administration Law 2012.

Hong Kong Ordinance Chapter 115 Immigration Ordinance 1997.

Macau Law No. 1/2004.

4 European Union

Directive 2011/95/EU of the European Parliament and of the Council on standards for the qualification of third-country nationals or stateless persons as beneficiaries of international protection, for a uniform status for refugees or for persons eligible for subsidiary protection, and for the content of the protection granted (recast) 2011.

5 North Korea

Criminal Code 2009

6 South Korea 
Constitution of the Republic of Korea 1987

Nationality Act 1948

Protection of North Korean Residents and Support of Their Settlement Act 1997

\section{International Treaties and Declarations}

Convention concerning the Status of Refugees coming from Germany (adopted on 10 February 1938).

Universal Declaration of Human Rights (adopted on 16 December 1949).

Geneva Convention (IV) Relative to the Protection of Civilian Persons in Time of War (opened for signature 12 August 1949, entered into force on 21 October 1950).

Convention relating to the Status of Refugees (opened for signature 28 July 1951, entered into force on 22 April 1954).

Protocol relating to the Status of Refugees (opened for accession 31 January 1967, entered into force on 4 October 1967).

Convention on Elimination of Racial Discrimination (adopted 21 December 1965, entered into force 4 January 1969).

International Covenant on Civil and Political Rights (adopted on 16 December 1966, entered into force 23 March 1976).

Organization of African Unity Convention Governing the Specific Aspects of Refugee Problems in Africa (adopted 10 September 1969, entered into force 20 June 1974).

Covenant on Economic, Social and Cultural Rights (opened for signature 19 December 1966, entered into force 3 January 1976).

Vienna Convention on the Law of Treaties (concluded on 23 May 1969, entered into force on 27 January 1980).

Convention on the Elimination of All Forms of Discrimination against Women (adopted on 18 December 1979, entered into force on 3 September 1981). 
Cartagena Declaration on Refugees, Colloquium on the International Protection of Refugees in Central America, Mexico and Panama (adopted on 22 November 1984).

The United Nations Convention against Torture and Other Cruel, Inhuman or Degrading Treatment or Punishment (adopted 10 December 1984, entered into force 26 June 1987).

Convention on the Rights of the Child (adopted 20 November 1989, entered into force 2 September 1990).

The People's Republic of China Ministry of Civil Affairs and Lao People's Democratic Republic Ministry of Social Welfare and Former Soldiers Protocol on the Repatriation of Lao Refugees (concluded on 10 April 1991).

The Government of People's Republic of China and the Government of the Union of Myanmar Protocol on Chinese-Myanmar Border Management and Cooperation (concluded 25 March 1997, entered into force 29 September 1997).

The Ministry of Public Security of the People's Republic China and The Ministry of National Security of the Democratic People's Republic of Korea Protocol on Cooperation in the Work of Maintaining National Security and Social Orders at Border Areas (concluded 8 July 1998, entered into force 28 August 1998).

AALCO Bangkok Principles on Status and Treatment of Refugees, AALCO/43/BALI/2004/SD/S 3 (adopted on 31 December 1966, amended on 24 June 2001).

ASEAN Human Rights Declaration (19 November 2012).

\section{United Nations Documents}

UN General Assembly Meeting on Refugees and Displaced Persons in South-East Asia, Convened by the Secretary-General of the United Nations at Geneva, on 20 and 21 July 1979, and Subsequent Developments: Report of the Secretary-General, A/34/627 (1979).

UNGA Summary Record of the 305th Meeting on 9th October 1979, Executive Committee of the High Commissioner's Programme, Thirtieth Session, A/AC.96/SR.305 (11 October 1979).

UNHCR Excom Conclusion on Protection of Asylum-Seekers in Situations of Large-Scale Influx, No. 22 (XXXII) - 1981 (21 October 1981). 
UNHCR Excom Note on the Protection of Refugees in Armed Conflict Situations, EC/SCP/25 (4 October 1982).

UNHCR Update on Regional Developments in Asia and Oceania, EC/46/SC/CRP.44 (1986).

UNGA Summary Record of the 407th meeting on 9 October 1986, Executive Committee of the High Commissioner's Programme, Thirty-Seventh Session, A/AC.96/SR.407 (16 October 1986).

UNHCR Handbook on Procedures and Criteria for Determining Refugee Status under the 1951 Convention and the 1967 Protocol relating to the Status of Refugees, HCR/IP/4/Eng/REV.1 (January 1992).

UNHCR Activities Financed by Voluntary Funds: Report for 1993-1994 and Proposed Programmes and Budget for 1995 Part II. Asia and Oceania Section 4 - China, A/AC.96/825/Part II/4 (1994).

UNHCR Comprehensive and Regional Approaches to Refugee Problems, EC/1994/SCP/CRP.3 (3 May 1994).

UNHCR Excom General Conclusion on International Protection, A/AC.96/839 (11 October 1994).

UNHCR The Scope of International Protection in Mass Influx, EC/1995/SCP/CRP.3 (2 June 1995).

UNHCR Note on International Protection, A/AC.96/850 (1 September 1995).

UNHCR Excom General Conclusion on International Protection, No. 79 (XLVII) - 1996 (11 October 1996).

UNHCR Excom Forty-seventh Session Summary Record of the 509th Meeting, A/AC.96/SR.509 (8 January1997).

UN General Assembly Resolution 51/75 Office of the United Nations High Commissioner for Refugees, A/RES/51/75 (12 February 1997).

UN General Assembly Resolution 52/132 Human Rights and Mass Exodux, A/RES/52/132 (27 February 1998).

UNHCR Protection of Refugees in Mass Influx Situations: Overall Protection Framework, EC/GC/01/4 19 (19 February 2001). 
UNHCR Global Consultations on International Protection Mechanisms of International Cooperation to Share Responsibilities and Burdens in Mass Influx Situations, EC/GC/01/7 (19 February 2001).

Concluding Observations of the Committee on the Elimination of Racial Discrimination: China, A/56/18 (9 August 2001).

UN Human Rights Committee Concluding Observations and Recommendations of the Human Rights Committee: Democratic People's Republic of Korea, CCPR/ CO/72/PRC (2001).

UNHCR Ensuring International Protection and Enhancing International Cooperation in Mass Influx Situations: Advance Summary Findings in the Study Commissioned by UNHCR, EC/54/SC/CRP.11 (June 2004).

UNHCR Excom Conclusion on International Cooperation and Burden and Responsibility Sharing in Mass Influx Situations, No. 100 (LV) - 2004 (8 October 2004).

Committee on the Rights of the Child Concluding Observations: China (including Hong Kong and Macau Special Administrative Regions), CRC/C/CHN/CO/2 (24 November 2005).

Vitit Muntarbhorn Report of the Special Rapporteur on the Situation of Human Rights in the Democratic People's Republic of Korea E/CN.4/2005/34 (2005).

Concluding Comments of the Committee on the Elimination of Discrimination against Women China, CEDAW/C/CHN/CO/6 (25 August 2006).

Vitit Muntarbhorn Report of the Special Rapporteur on the Situation of Human Rights in the Democratic People's Republic of Korea E/CN.4/2006/35 (23 January 2006).

Concluding Observations of the Committee against Torture: China, CAT/C/CHN/CO/4 (21 November 2008).

Vitit Muntharborn Report of the Special Rapporteur on the situation of human rights in the Democratic People's Republic of Korea, A/HRC/7/20 (15 February 2008).

Concluding Observations of the Committee on the Elimination of Racial Discrimination: China (including Hong Kong and Macau Special Administrative Regions), CERD/C/CHN/CO/10-13 (15 September 2009).

Ministerial Communiqué, HCR/MINCOMMS/2011/6 (8 December 2011). 
Committee on the Rights of the Child Concluding Observations on the Combined Third and Fourth Periodic Reports of China, adopted by the Committee at its Sixty-Fourth Session (16 September-4 October 2013), CRC/C/CHN/CO/3-4 (29 October 2013).

UNHCR Expert Roundtable Summary Conclusions on the Interpretation of the Extended Refugee Definition in the 1984 Cartagena Declaration (15 and 16 October 2013).

UN Human Rights Council Report of the Detailed Findings of the Commission of Inquiry on Human Rights in the Democratic People's Republic of Korea, A/HRC/25/CRP.1 (7 February 2014).

UN Human Rights Council Report of the Commission of Inquiry on Human Rights in the Democratic People's Republic of Korea, A/HRC/25/63 (7 February 2014).

\section{E Government Materials}

\section{Australia}

Australian Department of Immigration and Multicultural Affairs "Protection of Refugees in Mass Influx Situations: An Australian Contribution to UNHCR's Global Consultations on International Protection" (2001) Australian Government $<$ http://www.immi.gov.au/media/publications/refugee/unhcr/mass_influx.htm $>\quad$ (accessed 18 October 2013).

\section{China}

State Council Public Announcement 1982 NO14 Proposal on Reviewing, Discussing the Decision to accede to the Convention relating to the Status of Refugees and the Protocol relating to the Status of Refugees, 10 June 1982.

Ministry of Public Security, Security Management Bureau Reply to Jiangxi Province Resident ID Issuance Office's Enquiry about Whether to Issue ID Card to Refugees Returning to China 1989, GONGSAN[1989]NO350.

Ministry of Civil Affairs Administration Office Notice regarding Circulation of MCA Legislative Work Plan (29 July 2013), Chinese version available at MCA $<$ http://210.73.66.144:4601/law? fn=chl394s435.txt\&truetag $=846 \&$ titles $=\&$ contents $=\& \mathrm{dbt}=\mathrm{chl}>$ (accessed 25 April 2014). 
People's Republic of China 10th to 13th Periodic Reports on the Implementation of the International Convention on the Elimination of All Forms of Racial Discrimination, CERD/C/CHN/13 (24 June 2008).

People's Republic of China 3rd and 4th Combined Report on the Implementation of the Convention on the Rights of the Child, CRC/C/CHN/3-4 (6 June 2012).

People's Republic of China Combined 7th and 8th Periodic Reports on the Implementation of the Convention on the Elimination of All Forms of Discrimination against Women, CEDAW/C/CHN/7-8 (17 January 2013).

People's Republic of China 2nd Periodic Report on the Implementation of the Covenant on Economic, Social and Cultural Rights, E/C.12/CHN/2 (6 July 2012).

\section{South Korea}

Ministry of Unification "Peace and Prosperity: White Paper on Korean Unification" (2005), available at $<$ http://eng.unikorea.go.kr/content.do?cmsid=1819> (accessed 8 July 2013).

\section{F Books and Chapters in Books}

Alexander Betts et al UNHCR: The Politics and Practice of Refugee Protection (3rd ed, Routledge, London, 2012).

Sam Blay "Regional Developments: Asia" in Andreas Zimmermann (ed) The 1951 Convention Relating to the Status of Refugees and its 1967 Protocol: A Commentary (Oxford University Press 2011) 145.

Mary P Callahan Political Authority in Burma's Ethnic Minority States: Devolution, Occupation, and Coexistence (East-West Centre, Washington, 2007).

Nergis Canefe "The Fragmented Nature of the International Refugee Regime and Its Consequences: A Comparative Analysis of the Applications of the 1951 Convention" in James C Simeon (ed) Critical Issues in International Refugee Law (Cambridge University Press, Cambridge, 2010) 174.

Jean-Yves Carlier et al (eds) Who is a Refugee - A Comparative Case Law Studies (Kluwer Law International, the Hague, 1997).

Paomin Chang Beijing, Hanoi, and the Overseas Chinese (University of California Institute of East Asian Studies, Berkeley, 1982). 
Jianfu Chen "Constitutional Judicialisation and Popular Constitutionalism in China: Are We There Yet?" in Guanghua Yu (ed) The Development of the Chinese Legal System (Routledge, Oxon, 2011) 3.

Eunyoung Christina Choi "Everyday Practices of Bordering and the Threatened Bodies of Undocumented North Korean Border-Crossers" in Doris Wastl-Walter (ed) The Ashgate Research Companion to Border Studies (Ashgate, Farnham(UK), 2011) 507.

Michael P Colaresi Scare Tactics: The Politics of International Rivalry (Syracuse University Press, Syracuse, 2005).

Charles A Coppel “The Indonesian Chinese: 'Foreign Orientals', Netherlands Subjects, and Indonesian Citizens" in M Barry Hooker (ed) Law and the Chinese in Southeast Asia (Institute of Southeast Asian Studies, Singapore, 2002) 131.

Mary Crock, Ben Saul and Azadeh Dastyari Future Seekers II (The Federation Press, Annandale (NSW), 2006).

Sara Davies Legitimising Rejection: International Refugee Law in Southeast Asia (Martinus Nijhoff, Leiden, 2008).

Erika Feller, Volker Türk and Frances Nicholson (ed) Refugee Protection in International Law : UNHCR's Global Consultations on International Protection (Cambridge University Press, Cambridge, 2003).

David Feith Stalemate: Refugees in Asia (Asian Bureau Australia, Parkville, 1988).

Stephen Fitzgerald China and the Overseas Chinese A Study of Peking's Changing Policy 19491970 (Cambridge University Press, Cambridge, 1972).

Michelle Foster International Refugee Law and Socio-Economic Rights: Refuge from Deprivation (Cambridge University Press, Cambridge, 2009).

Guangxi Zhuang Autonomous Region Local Chronicle Commission "guangxi tongzhi: qiaowuzhi [Guangxi Chronicle: Overseas Chinese Affairs Chronicle]" (Guangxi People's Press, Nanning (China), 1996).

Matthew J Gibney The Ethics and Politics of Asylum: Liberal Democracy and The Response To Refugees (Cambridge University Press, Cambridge, 2004). 
Guy S Goodwin-Gill and Jane McAdam The Refugee in International Law (3rd ed, Oxford University Press, Oxford, 2007).

Atle Grahl-Madsen The Status of Refugees in International Law (Sijthoff, Leyden, 1966).

Guangxi Local Chronicles Editorial Committee Guangxi tongzhi - waishi zhi [Guangxi Local Chronicles - Foreign Affairs Chronicles] (online ed, 1996) Guangxi Local Information Web $<\mathrm{http}: / /$ www.gxdqw.com/bin/mse.exe?seachword=\&K=a\&A=25\&rec=16\&run=13 $>\quad$ (accessed 18 February 2013).

Stephan Haggard and Marcus Noland Witness to Transformation: Refugee Insights into North Korea (Peterson Institute for International Economics, Washington DC, 2011).

James C Hathaway and Michelle Foster The Law of Refugee Status (2nd ed, Cambridge University Press, Cambridge, 2014).

James C Hathaway The Rights of Refugees under International Law (Cambridge University Press, Cambridge, 2005).

Ralph Hassig and Kongdan Oh The Hidden People of North Korea: Everyday Life in the Hermit Kindom (Rowman \& Littlefield Publishers, Lanham (MD), 2009).

Stephan Haggard and Marcus Noland Witness to Transformation: Refugee Insights into North Korea (Peterson Institute for International Economics, Washington DC, 2011).

Taya Hunt and Nikola Errington "The Search for Protection in Southeast Asia" in Angus Francis and Rowena Maguire (ed) Protection of Refugees and Displaced Persons in the Asia Pacific Region (Ashgate, Farnham(UK), 2013) 53.

Ivor C Jackson The Refugee Concept in Group Situations (Martinus Nijhoff Publishers, The Hague, 1999).

Martin Jones and Sasha Baglay Refugee Law (Irwin Law, Toronto, 2007).

Susan Kneebone "ASEAN and the Conceptualisation of Refugee protection" in Ademola Abass and Francesca Ippolito (ed) Regional Approaches to the Protection of Asylum Seekers: An International Legal Perspective (Ashgate, Farnham(UK), 2014) 295.

Susan Kneebone and Felicity Rawlings-Sanaei (eds) New Regionalism and Asylum Seekers: Challenges Ahead (Berghahn Books, Oxford, 2007). 
Susan Kneebone "Introduction: Refugees and Asylum Seekers in the International Context Rights and Realities" in Susan Kneebone (ed) Refugees, Asylum Seekers and the Rule of Law (Cambridge University Press, 2009) 1.

Susan Kneebone "The Legal and Ethical Implications of Extra-territorial Processing of Asylum Seekers: the Safe Third Country Concept" in Jane McAdam (ed) Moving On: Forced Migration and Human Rights (Hart Publishing, Oxford, 2008) 129.

Susan Kneebone and Maria O'Sullivan “Article 1 C” in Andreas Zimmermann (ed) The 1951 Convention relating to the Status of Refugees and its 1967 Protocol: A Commentary (Oxford University Press, Oxford, 2011) 481.

Mikyoung Kim Securitization of Human Rights: North Korean Refugees in East Asia (Praeger, Santa Barbara (CA), 2012).

V K Wellington Koo The Status of Aliens in China (Longman, Green \& Co, London, 1912).

Pirkko Kourula Broadening the Edges: Refugee Definition and International Protection Revisited (Martinus Nijhoff Publishers, The Hague, 1997).

David Kranzler Japanese, Nazis and Jews, the Jewish Refugee Community of Shanghai 19381945, (Yeshiva University Press, New York, 1976).

Andrei Lankov "North Korean Refugees in Northeast China" (2004) 44 Asian Survey 856.

Marc Lanteigne China Foreign Policy: An Introduction (Routledge, New York, 2013).

Jerry Z Li and Sanzhuan Guo "China” in Dinah Shelton (ed) International Law and Domestic Legal Systems: Incorporation, Transformation, and Persuasion (Oxford University Press, Oxford, 2011) 158.

E R Leach Political Systems of Highland Burma: A Study of Kachin Social Structure (G Bell and Sons, London, 1970).

Xueju Li (ed) minzheng 30 nian [Civil Affair in the Past 30 Years] (China Society Press, Beijing, 2008).

Lee et al Changes in North Korea as revealed in the Testimonies of Saetomins (Korea Institute of National unification, Seoul, 2008). 
Shuying Liang guoji nanmin fa [International Refugee Law] (Intellectual Property Publishing House, Beijing, 2009).

Liang Shuying "Refugee Protection in China: The Issue of Citizenship and Potential Solutions" in Angus Francis and Rowena Maguire (ed) Protection of Refugees and Displaced Persons in the Asia Pacific Region (Ashgate, Farnham(UK), 2013) 67.

Guofu Liu Chinese Immigration Law (Ashgate, Farnham(UK), 2011).

Gil Loescher, Alexander Betts and James Milner The United Nations High Commissioner for Refugees: the politics and practice of refugee protection into the twenty-first century (Routledge, London, 2008).

Gil Loescher Beyond Charity: International Cooperation and the Global Refugee Crisis (Oxford University Press, Oxford, 1993).

Sylvie Da Lomba “The EU Qualification Directive and Refugees Sur Place" in Flora A N J Goudappel and Helena S Raulus (eds) The Future of Asylum in the European Union-Problems, Proposals and Human Rights (T M C Asser Press, The Hague, 2011) 43.

Kelley Loper "The Protection of Asylum Seekers in East Asian State Parties to the 1951 Convention Relating to the Status of Refugees and its 1967 Protocol” in Ademola Abass and Francesca Ippolito (ed) Regional Approaches to the Protection of Asylum Seekers: An International Legal Perspective (Ashgate, Farnham(UK), 2014) 347.

Michael Marrus The Unwanted European Refugees in the Twentieth Century (Oxford University Press, Oxford, 1985).

Jane McAdam "Interpretation of the Refugee Convention" in Andreas Zimmermann (ed) The 1951 Convention Relating to the Status of Refugees and its 1967 Protocol: A Commentary (Oxford University Press, Oxford, 2011) 75.

Sai Kaham Mong Kokang and Kachin in the Shan State (Institute of Asian Studies, Bangkok, 2005).

David Mozingo Chinese Policy toward Indonesia, 1949-1067 (Cornell University Press, Ithaca, 1976).

Vitit Muntarbhorn The Status of Refugees in Asia (Clarendon Press, Oxford, 1992). 
Vitit Muntarbhorn "Identifying Creative Entry Points for Refugee Protection: Recent Lessons from the Asia-Pacific Region" in James C Simeon (ed) The UNHCR and the Supervision of International Refugee Law (Cambridge University Press, Cambridge, 2013) 257-272.

Nïraj Nathwani Rethinking Refugee Law (Martinus Nijhoff, The Hague, 2003).

Anthony M North and Joyce Chia "Towards Convergence in the Interpretation of the Refugee Convention: A Proposal for the Establishment of an International Judicial Commission for Refugees" in Jane McAdam (ed) Forced Migration, Human Rights and Security (Hart Publishing, Oxford, 2008) 225.

Randall Peerenboom China's Long March toward Rule of Law (Cambridge University Press, Cambridge, 2002).

Maria Redei "Hungary" in Solon Ardittis (ed) The Politics of East-West Migration (St. Martin's Press, New York, 1994) 89.

Refugee Status Appeals Authority New Zealand Ahmed Zaoui: Refugee Status Appeals Authority New Zealand, Refugee Appeal NO. 74540, 1 August 2003 (Human Rights Foundation, Auckland, 2005).

Dallal Stevens "Shifting Conceptions of Refugee Identity and Protection: European and Middle Eastern Approaches" in Kneebone, Stevens, and Baldassar (eds) Refugee Protection and the Role of Law: Conflicting Identities (Routledge, Oxon, 2014) 73.

W C Robinson Terms of Refuge: the Indochinese Exodus \& the International Response (Zed Books, London, 1998).

Pamela Rotner Sakamoto Japanese diplomats and Jewish refugees: a World War II dilemma (Praeger, Westport(Conn), 1998).

Marina Sharpe "The Impact of European Refugee Law on the Regional, Sub-Regional and National Planes in Africa" in Helene Lambert, Maryellen Fullerton and Jane McAdam (eds) The Global Reach of European Refugee Law (Cambridge University Press, 2013) 178-200.

Hazel Smith "North Koreans in China: Sorting Fact from Fiction" in Tsuneo Akaha and Anna Vassilieva (ed) Crossing National Borders: Human Migration Issues in Northeast Asia (United Nations University Press, Tokyo, 2005) 165. 
Daniel Steinbock “The Refugee Definition as Law: Issues of Interpretation” in Nicholson and Twomey (ed) Refugee Rights and Realities (Cambridge University Press, Cambridge, 1999) 13.

Leo Suryadinata "China's Citizenship Law and the Chinese in Southeast Asia" in M Barry Hooker (ed) Law and the Chinese in Southeast Asia (Institute of Southeast Asian Studies, Singapore, 2002) 169.

Jerzy Sztucki "Who is a Refugee? The Convention Definition: Universal or Obsolete?" in Nicholson and Twomey (ed) Refugee Rights and Realities (Cambridge University Press, Cambridge, 1999) 55.

Doug Tennent Immigration and Refugee Law (LexisNexis, Wellington, 2010).

UNHCR The State of the World's Refugees 2012: In Search of Solidarity (Oxford University Press, Oxford, 2012).

UNHCR Refugee Protection: A Guide to International Refugee Law (UNHCR and InterParliamentary Union, Geneva, 2001), available at Refworld $<$ http://www.refworld.org/docid/3cd6a8444.html > (accessed 1 September 2014).

John Vrachnas, Mirko Bagaric, Penny Dimopoulos and Athula Pathinayake Migration and Refugee Law: Principles and Practice in Australia (3rd ed, Cambridge University Press, Melbourne, 2012).

Andreas Zimmermann and Claudia Mahlet "Article 1 A, para. 21951 Convention” in Andreas Zimmermann(ed) The 1951 Convention Relating to the Status of Refugees and its 1967 Protocol: A Commentary (Oxford University Press, Oxford, 2011) 1.

Andreas Zimmermann (ed) The 1951 Convention Relating to the Status of Refugees and its 1967 Protocol: A Commentary (Oxford University Press, Oxford, 2011).

\section{G Journal Articles}

Matthew Albert "Governance and Prima Facie Refugee Status Determination: Clarifying the Boundaries of Temporary Protection, Group Determination and Mass Influx" (2010) 29(1) Refugee Survey Quarterly 61.

Eduardo Arboleda "Refugee Definition in Africa and Latin America: The Lessons of Pragmatism" (1991) 3(2) International Journal of Refugee Law 185. 
Alexander Betts "Towards a 'Soft Law' Framework for the Protection of Vulnerable Irregular Migrants" (2010) 22(2) International Journal of Refugee Law 209.

Alice Bloch "Carrying Out a Survey of Refugees: Some Methodological Considerations and Guidelines" (1999)12 Journal of Refugee Studies 367.

Elim Chan and Andreas Schloenhardt "North Korean Refugees and International Refugee Law" (2007) 19 International Journal of Refugee Law 215.

Shibing Cao "The Legal Status of Decisions and Judicial Interpretations of the Supreme Court of China" (2008) 3(1) Frontiers of Law in China 1.

Paomin Chang "The Sino-Vietnamese Dispute over the Ethnic Chinese" (1982) 90 The China Quarterly 195.

Tung-Pi Chen "The Nationality Law of the People's Republic of China and the Overseas Chinese in Hong Kong, Macao and Southeast Asia" (1984) 5 New York Law School Journal of International and Comparative Law 281.

Joyce Chia and Susan Kenny "The Children of Mae La: Reflections on Regional Refugee Cooperation" (2012) 13 Melbourne Journal of International Law 838.

B S Chimni "Reforming the International Refugee Regime: A Dialogic Model” (2001) 14(2) Journal of Refugee Studies 151.

Lawrence Cox “The Failure of the People's Republic to Extend the Refugee Convention to Hong Kong: the Contemporary Use of the Colonial Clause by a Non-Colonial Power to Circumvent Human Rights Obligations” (2008) 4(2) Journal of Migration and Refugee Issues 80.

Cara Cutler "China's Provision of Temporary Visas to North Koreans - Reconsidering the Protection of migrants in the 21st Century" (2006) Stanford Journal on East Asia Affairs, winter, 63.

Shichao Deng and Lichang Huang "zhongguo yuenan guiguo nanqiao de anzhi yu shengchan shenghuo xianzhuang tanxi: yi Guangdong yangcun huaqiao ganjuchang weili [Analysis on Reception of Overseas Chinese in Difficulty Returning from Vietnam and Their Present Work and Life Conditions: A Case Study of Guangdong Yang Village Overseas Chinese Mandarin Farm]" (2010) 58 Ritsumeikan University Journal of Economics 87. 
Jean-François Durieux "The Many Faces of Prima-Facie Group-Based Evidence in Refugee Status Determination" (2009) 25 (2) Refuge 151.

Jean-François Durieux and Jane McAdam "Non-Refoulement through Time: The Case for a Derogation Clause to the Refugee Convention in Mass Influx Emergencies" (2004) 16(4) International Journal of Refugee Law 4.

Angus Francis “China’s Refugee Policy: Pathways to Reform” (2011) 17(1) Australian Journal of Human Rights 29.

Kaipeng Gan "woguo nanmin baohu falü zhidu de queshi ji goujian [The Lack of Legal System of Refugee Protection and its Establishment]" (2010) 1 Science Economy Society 151.

Michael Godley "A Summer Cruise to Nowhere: China and the Vietnamese Chinese in Perspective" (1980) 4 The Australian Journal of Chinese Affairs 35.

Guy Goodwin-Gill “The Politics of Refugee Protection” (2008) 27 Refugee Survey Quarterly 8.

Atle Grahl-Madsen "International Refugee Law Today and Tomorrow" (1982) 20 Archiv des Völkerrechts 411.

Felix Gruenberger "The Jewish Refugees in Shanghai" (1950) 12 Jewish Social Studies 329.

Sanzhuan Guo "Implementation of Human Rights Treaties by Chinese Courts: Problems and Prospects" (2009) 8(1) Chinese Journal of International Law 161.

Tristan Harley "Regional Cooperation and Refugee Protection in Latin America: A 'South-South' Approach" (2014) 26(1) International Journal of Refugee Law 22.

James C Hathaway “The Evolution of Refugee Status in International Law: 1920-1950” (1984) 33 International and Comparative Law Quarterly 348.

Xiaorong Han "Exiled to the Ancestral Land: the Resettlement, Stratification and Assimilation of the Refugees from Vietnam in China" (2013) 10 International Journal of Asian Studies 25.

Nicholas van Hear "Forcing the Issue: Migration Crises and the Uneasy Dialogue between Refugee Research and Policy” (2011) 25(1) Journal of Refugee Studies 2. 
Jianhua Huang and Wenhua Ma "Yang Zhengxin yu eguo nanmin cuanrao Xinjiang shijian [Yang Zhengxin and the Influx of Russian Refugees in Xinjiang]" (1994) 4 Yili shifan xueyuan xuebao [Journal of Yili Teachers' College] 74.

Ju Hui Judy Han "Beyond Safe Haven - A Critique of Christian Custody of North Korean Migrants in China" (2013) 45(4) Critical Asian Studies 533.

Jianhua Huang and Wenhua Ma "Yang Zhengxin yu eguo nanmin cuanrao Xinjiang shijian [Yang Zhengxin and the Influx of Russian Refugees in Xinjiang]" (1994) 4 Yili shifan xueyuan xuebao [Journal of Yili Teachers' College] 74.

Martin Jones and France Houle "Building a Better Refugee Status Determination System" (2008) 25(2) Refuge 3.

Stephane Jaquemet "The Cross-Fertilization of International Humanitarian Law and International Refugee Law” (2001) 83(843) International Review of the Red Cross 651.

Yuan Ji "Crafting a Multilateral Solution for North Korean Refugee Settlement: What American Policymakers can Learn from the Indochinese Refugee Crisis” (2011) 6 Journal of International Law \& International Relations 53.

Ronald C Keith and Zhiqiu Lin “Judicial Interpretation of China's Supreme People's Court as ‘Secondary Law’ with Special Reference to Criminal Law” (2009) 23 China Information 223.

Byung-yeon Kim and Dongho Song "The participation of North Korean Households in the Informal Economy: Size, Determinant, and Effect” (2008) 21 Seoul Journal of Economics 361.

Melissa Kim "North Korean Escapees in China: Granting Prima Facie Refugee Status Based on a Group Determination” (2010) 2 Journal of East Asia and International Law 423.

Koichi Koizumi "Refugee Policy Formation in Japan: Developments and Implications" (1992) 5(2) Journal of Refugee Studies 123.

Khalid Koser and Richard Black "Limits to Harmonization: The 'Temporary Protection' of Refugees in the European Union” (1999) 37 (3) International Migration 521.

Tom Lam "The Exodus of Hoa Refugees from Vietnam and Their Settlement in GuangxiChina's Refugee Settlement Strategies” (2000) 13 Journal of Refugee studies 374. 
Helene Lambert "The Next Frontier: Expanding Protection in Europe for Victims of Armed Conflict and Indiscriminate Violence" (2013) 25(2) International Journal of Refugee Law 207.

Lihong Lan and Xiuxia Shi "Reflection on the Latest Progress in Chinese Legislation on International Migration" (2013) 8(3) Frontiers of Law in China 618.

Andrei Lankov "North Korean Refugees in Northeastern China” (2004) 44(6) Asian Survey 856.

Andrei Lankov and Seok-hyang Kim "North Korea Market Vendors: The Rise of Grassroots Capitalists in a Post Stalinist Society (2008) 81 Pacific Affairs 53.

Chen Chen Lee "Refugee Policy is a Realist's Nightmare: The Case of Southeast Asia" (2006) 3(2) Migration Letters 137.

Eric Yong Joong Lee "National and International Legal Concerns over the Recent North Korean Escapees" (2001) 13 International Journal of Refugee Law 142.

Defu Li "kaizhan qianfan nanmin gongzuo de chubu tihui [Preliminary Reflection on Works of Repatriating Refugees]" (1994) 10 zhongguo minzheng (Chinese Civil Affairs) 26.

Yongwei Liu "guoij tiaoyue zai zhongguo shiyong xinlun [Some New Thoughts on Application of Treaties in China]" (2007) 2 Jurists Review 143.

Chengdu Liu "dui gongan churujing guanli bumen jiaqiang nanmin guanli de jidian sikao [Several Thoughts on Improving Refugee Administration by Border Exit and Entry Administration Department of Public Security System]" (2000) 4 Journal of Beijing People's Police College 46.

Yongwei Liu "guoji tiaoyue zai zhongguo shiyong xinlun [New Thoughts on Application of International Treaties in China]" (2007) 2 Faxuejia [Jurists Review] 143.

Kelley Loper "Human Rights, Non-Refoulement and the Protection of Refugees in Hong Kong" (2010) 22(3) International Journal of Refugee Law 404.

Campbell McLachlan "The Principle of Systemic Integration and Article 31(3)(c) of The Vienna Convention" (2005) 54(2) International and Comparative Law Quarterly 279.

Katherine Morton "The Emergence of NGOs in China and Their Transnational Linkages: Implication for Domestic Reform” (2005) 59(4) Australian Journal of International Affairs 527. 
David Mozingo “The Sino-Indonesian Dual Nationality Treaty” (1961) 1(10) Asian Survey 25.

Benjamin Neaderland "Quandary on the Yalu: International Law, Politics, and China's North Korean Refugee Crisis” (2004) 40 Stanford Journal of International Law 143.

Katie O'Byrne "Is There a Need for Better Supervision of the Convention?" (2013) 26(3) Journal of Refugee Studies 330.

Pia Oberei "Regional Initiatives on Refugee Protection in South Asia" (1999) 11(1) International Journal of Refugee Law 193.

Yeo Hoon Julie Park "China's 'Way Out' of the North Korean Refugee Crisis: Developing a Legal Framework for the Deportation of North Korean Migrants" (2010) 25 Georgetown Immigration Law Journal 515.

Glen Peterson "The Uneven Development of the International Refugee Regime in Postwar Asia: Evidence from China, Hong Kong and Indonesia" (2012) 25 Journal of Refugee Studies 326, at 328.

Drew Thompson “Border Burdens: China's Response to the Myanmar Refugee Crisis" (2009) 5 China Security 11.

Suzanne Rutland "Waiting Room Shanghai': Australian Reactions to the Plight of the Jews in Shanghai after the Second World War" (1987) 32 Year book - Leo Baeck Institute 407.

Andrew E Shacknove "Who is a Refugee?" (1985) 95(2) Ethics 274.

Quancheng Song "ouzhong yu zhongguo: feifa yimin jiqi shihui kongzhi zhengce zhibijiao [A Comparasion of Illegal Migrants and Relevant Social Control in Europe and China] (2011) 8 Shandong Social Science 23.

Andrew Shacknove "Who is a Refugee?” (1985) 95 Ethics 274.

Sung An Tai "Vietnam: the Defection of Hoang Van Hoan” (1980) 7 Asian Affairs 288.

Yuanjun Wang "guanyu jianli woguo nanmin baohu falv zhidu de jidian sikao [Several Thoughts on Establishment of Refugee Protection Mechanism in China]"(2005) 12 Public Security Research 46. 
Jinrong Wang “On the Judicial Interpretation of China's supreme People's Court" (1995) 3 China L 9, cited from Li Wei "Judicial Interpretation in China" (1997) 5 Willamette Journal of International Law and Dispute Resolution 87.

Lin Wen "xinzhongguo shouci daguimo cheqiao shimo [New China's First Large-scale Evacuation of Overseas Chinese]" (2012) 5 Wenshi Chunqiu [Literature and History] 17.

Andrew Wolman "North Korean Asylum Seekers and Dual Nationality" (2012) 24(4) International Journal of Refugee Law 793.

Dayou Xiang "rang shiren liaojie guangxi jiedai anzhi yinzhi nanmin de zhenxiang [Let People around the World Know about the Truth of Guangxi's Reception and Settlement of Indochinese Refugees]" (2011) 1 Overseas Chinese Journal of Bagui 3.

Hanqin Xue and Qian Jin "International Treaties in the Chinese Domestic Legal System” (2009) 8(2) Chinese Journal of International Law 299.

Zhigang $\mathrm{Yu}$ "chengshi guojia de guojihua yu toudufanzui de xingshi zhengce [The Internationalisation of States and Cities and the Criminal Policy regarding Illegal Border Crossing” (2014) 2 Qinghua University Journal 101.

Guohua Zeng “Guangxi nanqiao peixun gongzuo de lanshang xianzhuang he tiaozhan [Status Quo of and Challenges for Trainings of Nanqiao in Guangxi]" (2006) 2 bagui qiaokan [Overseas Chinese Journals of Bagui] 47.

\section{H Dissertations}

Yun Cheng "nanmin diwei guoji gongyue ji chaoxian 'nanmin' wenti zhi yanjiu [The International Convention relating to the Status of Refugees and the Issue of North Korean 'Refugees']" (Master dissertation, Dalian Maritime University, 2007).

Myint Myint Kyu "Spaces of Exception and Shifting Strategies of the Kokang Chinese along the Myanmar/China Border” (Master’s Dissertation, Chiang Mai University, 2011).

Nhi Ky Luong "The Chinese in Vietnam: a Study of Vietnamese-Chinese Relations with Special Attention to the Period 1862-1961" (PhD Thesis, University of Michigan, 1963).

\section{Internet Resources}

"2012 nian zhongshan daxue moni lianheguo dahui nanmin anzhi yu nanmin quanli baozhang beijing wenjian [2012 Sun Yat-Sun University Moot UN Meeting on Refugee Settlement and 
Rights Protection Background Document]" (19 April 2012) School of Asian Pacific Study of Sun Yat-Sen University <http://saps.sysu.edu.cn/xsyd/zsdxmnlhg/96477.htm> (accessed 9 March 2013).

"About the Bali Process" Bali Process <http://www.baliprocess.net/> (accessed 9 April 2014).

"Aid Groups Say China is Expelling Kachin Refugees" (23 June 2011) VOA $<$ http://blogs.voanews.com/breaking-news/2011/06/23/aid-groups-say-china-is-expellingkachin-refugees/> (accessed 28 April 2014).

“APC's focus" Asia-Pacific Consultations on Refugees, Displaced Persons and Migrants (APC) $<$ http://www.apcprocess.net/aboutus.htm> (accessed 9 April 2014).

"APC" International Organization for Migration $(\mathrm{IOM})$

$<$ https://www.iom.int/cms/en/sites/iom/home/what-we-do/regional-processes-1/rcps-byregion/apc.html > (accessed 9 April 2014).

"Canada to Deport Chinese Fugitive Lai Changxing" (22 July 2011) BBC $<$ http://www.bbc.co.uk/news/world-us-canada-14245141> (accessed 28 April 2014).

"chaoxian tuobeizhe laihua jing dongnanya fuhan xiangxi luxian baoguang [Revealing Detailed Route Used by North Korean Escapees to Go to South Korea from China via Southeast Asia]" (26 December 2013) Sina <http://news.sina.com.cn/c/2013-12-26/015629082245.shtml> (accessed 28 April 2014).

"China Pro Bono Directory" Fahamu Refugee Programme $<$ http://www.refugeelegalaidinformation.org/china-pro-bono-directory $>$ (accessed 17 April 2014).

"China's Current Legislation Structure" (2003) China Net $<$ http://www.china.org.cn/english/kuaixun/76212.htm> (accessed 12 April 2014).

“China's Relationship with United Nations High Commissioner for Refugees (UNHCR)" (16 Apr 2004) Chinese Permanent Mission to Geneva <http://www.chinaun.ch/eng/rqrd/jblc/t85094.htm> (accessed 12 March 2013).

“churujing bianfang jiancha zongzhan ji xiashu churujing bianfang jianchazhan [Exit-Entry Inspection Head Station and Exit-Entry Stations under It” (3 July 2008) Bureau of Exit and 
Entry Administration of the MPS <http://www.mps.gov.cn/n16/n84147/n84165/1291480.html> (accessed 19 October 2013).

“Dai Bingguo Meets UN High Commissioner for Refugees Guterres” (3 September 2010), MFA <http://www.fmprc.gov.cn/chn/pds/gjhdq/gjhdqzz/lhg/xgxw/t737390.htm> (accessed 8 April 2014).

"duiwai hezuo chu 2009 nian gongzuo zongjie he 2010 nian gongzuo jihua [Office of External Cooperation 2009 Work Report and 2010 Work Plan]" (8 Mar 2010) Yunnan Civil Affairs $<$ http://yunnan.mca.gov.cn/article/ztzl/mzgzh/cszj/201003/20100300060711.shtml $>$ (accessed 10 March 2014).

"Edward Snowden 'Broadens Asylum Requests' - Wikileaks" (2 July 2013) BBC $<$ http://www.bbc.com/news/world-europe-23139980> (accessed 28 April 2014).

"Explaining North Korean Migration to China-North Korea International Documentation Project E-Dossier" $\quad$ (September 2012) Wilson $\quad$ Center $<$ http://www.wilsoncenter.org/publication/explaining-north-korean-migration-to-china> (accessed 2 September 2014).

'guogan gaikuang [Basic Facts of Kokang]' Righteous Kokang <www.righteouskokang.com> (access 8 August 2013).

"Hainansheng jiedai anzhi yinzhi nanmin bangongshi (Hainan Province Office of Reception and Settlement of Indochinese Refugees" (14 November 2007) The People's Government of Hainan Province <http://www.hainan.gov.cn/data/kstd/2007/11/147/> (accessed 1 September 2013).

"Japan-China spat over North Koreans" (9 May 2002) BBC <http://news.bbc.co.uk/2/hi/asiapacific/1976702.stm> (accessed 20 April 2014).

"jiaoda zhiyuanzhe zai Yunnan bianchun anquan duguo guogan zhanshi [Jiaotong University Volunteers Survived Kokang War]" (24 September 2009) Shanghai Jiaotong University $<$ http://topics.sjtu.edu.cn/newsnet/shownews.php?id=22669> (accessed 23 April 2014).

"Kachin IDPs Reach over 40,000 due to Civil War in Northern Burma" (2 September 2011) Kachin News <http:/www.kachinnews.com/news/2040-kachin-idps-reach-over-40000-due-tocivil-war-in-northern-burma.html> (accessed 28 April 2014). 
"Kokang Capital Falls: 'Not Shoot First' Policy under Fire" (26 August 2009) Shan Herald Agency for

News

$<$ http://www.shanland.org/index.php?option=com_content\&view=article\&id=2695:kokangcapital-falls-not-shoot-first-policy-under-fire\&catid=86:war\&Itemid=284> $\quad$ (accessed 14 September 2011).

"lianheguo nanmin lifa yantaohui zai pingyao gucheng juxing [UN Symposium on Legislation of Refugee Law Held in Ancient Pingyao County]" (2006) People's Government of Pingyao County $<$ www.pingyao.gov.cn $>$ (accessed 8 August 2012).

"Main Responsibilities of the Ministry of Foreign Affairs of the People's Republic of China" MFA <http://www.fmprc.gov.cn/eng/wjb/zyzz/> (accessed 2 August 2012).

"Malayan People's Army. 10th Regiment Archives" International Institute of Social History $<$ http://www.iisg.nl/archives/en/files/m/ARCH02799.php> (accessed 11 April 2014).

"Macau (Special Administrative Region of China) Statistical Snapshot" (2014) UNHCR $<$ www.unhcr.org/pages/49e488436.html > (accessed 7 April 2014).

"miandian guogan diqu fasheng zhanshi daliang bianmin yongru wojing [Clashes Took Place in Myanmar's Kokang Region, Large Numbers of Border Residents Poured into China]" (27 August 2009) Yunnan Net <http://yn.yunnan.cn/html/2009-08/27/content_887539.htm> (accessed 26 April 2014).

"miandian keqin dulijun qingqiu zhongguo tiaojie yu junzhengfu chongtu [Burmese Kachin Independent Army Seeks China's Intercession in Conflicts with Government Force]" (17 June 2011) Yahoo China < http://news.cn.yahoo.com/ypen/20110617/421652.html> (accessed 6 July 2011).

"Miandian keqin wuzhuan zan bu pohuai zhongmian youqi guandao deng zhongguo huiying [Burma's Kachin Army Has not Ruined China-Myanmar Oil and Gas Pipes, Awaiting China's Response]" (6 June 2011) China News <http://www.chinanews.com/gj/2011/0616/3115812.shtml $>$ (accessed 28 April 2014).

"minzhengbu zhuyao zhize [Main Duties and Responsibilities of Ministry of Civil Affairs]" MCA, <http://www.mca.gov.cn/article/zwgk/jggl/zyzz/> (accessed 2 August 2012).

"nanmin lifa yantaohui zai lijiang juxing [Symposium on Legislation of Refugee Law was Held in Lijiang City]" (2007) Ministry of Foreign Affairs of PRC < www.mfa.gov.cn>. 
"No Refugee Status Ever Granted" (29 September 2014) Macau Daily Times $<$ http://www.macaudailytimes.com.mo/macau/30055-no-refugee-status-ever-granted.html> (accessed 7 April 2014).

"Press Conference by Minister of Foreign Affairs Li Zhaoxing during the Second Session of the 10th NPC" (6 March 2004) MFA <http://www.fmprc.gov.cn/eng/wjb/wjbz/2467/t71616.htm> (accessed 19 September 2012).

“qingyi wuxian xihanuke 'liuwang' zhongguo wunian jishi [Infinite Friendship: True Stories of Sihanouk's 5 Years of 'Exile' in China]" China Net (21 July 2010) $<$ http://culture.china.com/zh_cn/history/files/11022841/20100721/16035891_1.html> (accessed 28 April 2014).

"Regional Support Office” Bali Process < http://www.baliprocess.net/regional-support-office> (accessed 23 April 2014).

"Refugees Storm Beijing Embassy" (29 September 2004) BBC < http://news.bbc.co.uk/2/hi/asiapacific/3699786.stm> (accessed 20 April 2014).

"shewai jiazheng, waiguoren feifa jiuye duofa [Foreigners Frequently Found Illegally Working as Housemaids]" (26 April 2012) Xinhua <http://www.npc.gov.cn/huiyi/cwh/1126/201204/26/content_1719376.htm> (accessed 28 April 2014).

"Tacheng de waiguo qiaomin [Foreign Sojourners in Tacheng]" (20 July 2011) Tacheng Municipality

$<$ http://www.xjtcsh.gov.cn/tcgk/rwsl/201107/t4028a8ab3145442001314701c94f04dd.html> (accessed 28 April 2014).

“tongjiju fabu 2011 nian woguo renkou zongliang ji jiegou bianhua qingkuang [Statistic Bureau Released Information of Our Country's Population and Its Structural Changes]" (18 January 2012) The Central People's Government of China <http://www.gov.cn/gzdt/201201/18/content_2047892.htm> (accessed 16 April 2014).

“Tokuda, Kyuichi” National Diet Library, Japan $<$ http://www.ndl.go.jp/portrait/e/datas/407.html?cat=119> (accessed 11 April 2014).

“waiguoren ruhe dedao zhongguo 'bihu' [How Can Foreigners Receive Asylum in China]" (18 December 2013) Sohu News <http://news.sohu.com/s2013/dianji-1291/> (accessed 11 April 2014). 
"waijiaobu yu lianheguo nanminshu lianhe juban nanmin lifa yantaohui [Ministry of Foreign Affairs and UNHCR Jointly hold Symposium on Legislation of Refugee Law]" (2004) MFA $<$ http://www.fmprc.gov.cn/chn/gxh/mtb/sjhd/t140393.htm> (accessed 19 September 2011).

"War Snowballs: Kachin Refugees Influx to China Border" (24 June 2011) Kachin News Group $<$ http://www.kachinnews.com/news/1955-war-snowballs-kachin-refugees-influx-to-chinaborder.html $>$ (accessed 9 January 2012).

"xinshiji yilai waiguoren rujing renshu meinian dizeng 10\% [Number of Foreigners Entering China Increases 10 Per Cent Each Year Since Year 2000]" (25 April 2013) Xinhua $<$ http://news.xinhuanet.com/legal/2012-04/25/c_111842921.htm> (accessed 20 February 2014).

"yafei falü xieshang zuzhi (AALCO) [Asian-African Legal Consultative Organization (ALLCO)]" (30 March 2006) People Web <http://world.people.com.cn/GB/8212/60991/60995/4254971.html> (accessed 6 April 2014).

"Yunnansheng zhengfu jiu danqian zhongmian bianjing jushi juxing xinwen fabuhui [Yunnan Government Holds Press Conference on Situation on China-Myanmar Border]" (2009) SCIO $<$ http://www.scio.gov.cn/xwfbh/gssxwfbh/xwfbh/yunnan/200908/t398584.htm> (accessed 9 January 2012).

"zhongmian bianjing jianwen: liuqian miandian bianmin yi luxu huiguo [News from ChinaMyanmar Border: 6,000 Myanmar Border People Have Returned to Myanmar Gradually]" (2009) China News <http://www.chinanews.com/gn/news/2009/09-01/1844364.shtml> (accessed 24 September 2011).

"zhongguo yi canjia 27 xiang renquan tiaoyue [China has Participated in 27 International Human Rights Treaties]" (2011) China Human Rights <www.humanrights-china.org> (accessed 9 January 2012).

"zhongguo yu yafei falü xieshang zuzhi [China and AALCO]" MFA $<$ www.fmprc.gov.cn/tyfls/bjzl/t84239.html> (accessed 6 April 2014).

"zhongguo 'nigei liangwan chaoxianren gongzuo qianzheng' [China is to issue work visa to 20,000 North Koreans]” (26 May 2012) BBC China $<$ http://www.bbc.co.uk/zhongwen/simp/chinese_news/2012/05/120526_china_nkorea_workper mits.shtml> (accessed 25 April 2014). 
“ $<$ zhongmian bainjing guanli hezuo xieding $>$ di shierlun sijuji huiwu zaimian juxing $\left[\right.$ The $12^{\text {th }}$ Department and Bureau Level Meeting on the Implementation of the China-Myanmar Protocol on Border Management and Cooperation Held in Myanmar]" (25 February 2014) MFA $<$ http://www.fmprc.gov.cn/mfa_chn/wjb_602314/zzjg_602420/t1131797.shtml> (accessed 7 April 2014).

"zhuanjia cheng zhongguo weilai chengwei xin yiminguojia kenengxing da [Expert Says It Is Highly Possible that China Would Become a New Immigration Country in the Future]" (30 June 2010) Sina <http://news.sina.com.cn/c/sd/2010-06-30/115120579697.shtml> (accessed 28 April 2014).

Ad Hoc Committee on Statelessness and Related Problems, Status of Refugees and Stateless Persons - Memorandum by the Secretary-General, 3 January 1950, available at UNHCR $<$ http://www.unhcr.org/3ae68c280.html> (accessed 19 Mar 2014).

Jamil Anderlini "China presses Thailand to return Uighur refugees" Financial Times (Online ed, 3 April 2014), available at <http://www.ft.com/intl/cms/s/0/35bbf33a-bb1d-11e3-948c00144feabdc0.html\#axzz3I4pBroPA> (accessed 20 June 2014).

Kaung Ba "Kachin State Refugees Face Uncertain Future" (1 July 2011) The Irrawaddy $<$ http://www2.irrawaddy.org/article.php?art_id=21612> (accessed 28 April 2014).

Ruobing Chen (ed) 'yige 'tuobei' jiating de 10 nian [Ten Years of a 'North Korean Escapee' Family]” (5 January 2012) Tengxun <http://news.qq.com/zt2011/shijie/nkrefugee.htm> (accessed 28 April 2014).

Liangfei Chen "Guogan 350 nian: shiluo de shijie (350 Years of Kokang: the Lost World)" (9 Sep 2009) Sina News <http://news.sina.com.cn/w/sd/2009-09-09/181518615604_3.shtml> (accessed 6 September 2013).

David Cohen "China's Myanmar Problem" (17 Jan 2013) The Diplomat $<$ http://thediplomat.com/2013/01/chinas-myanmar-problem/> (accessed 19 February 2013).

Roberta Cohen "Legal Grounds for Protection of North Korean Refugees" (12 September 2010) Brookings $\quad<$ http://www.brookings.edu/research/opinions/2010/09/north-korea-human-rightscohen $>$ (accessed 28 April 2014). 
China Human Rights Studies Association "zhongguo jiaru le naxie guoji renquan gongyue he yidingshu [Which International Human Rights Treaties and Protocols Has China Ratified]" (27 March 2006) People Web <http://theory.people.com.cn/GB/49150/49152/4239175.html> (accessed 28 April 2014).

Yiwen Deng "shifang tuobeizhe bingfei Beijing gaibian lichang [Releasing North Korean Escapees Does not Mean Beijing Has Changed its Position" Financial Times Chinese Edition (online ed, 18 August 2014), available at <http://www.ftchinese.com/story/001057773?full=y $>$ (accessed 20 October 2014).

Emergency Response Management Office of the People's Government of Yunnan Province "jiceng yingji guanli shifan danwei Tengchong xian yingji guanli gongzuo shijian [Emergency Response Practice of Tengchong, A Model Grassroot Unit in Emergency Response]" (26 October 2012) Environment Protection Department of Hunan Province $<$ http://www.hbj.hunan.gov.cn/hjjc/hjyj/content_32894.html > (accessed 2 April 2014).

Euro-Burma Office (EBO) “The Kokang Clashes - What Next?” (September 2009) EBO $<$ http://euro-burma.eu/doc/EBO_Analysis_No_1_(Kokang).pdf $>$ (accessed April 2014).

Susanna Fischer "A Brief Introduction to the Legal System of China" (2002) The Catholic University of America <http:/faculty.cua.edu/fischer/ComparativeLaw2002/bauer/Chinamain.htm> (accessed 12 April 2014).

Fund for Peace Failed States Index (2013), Fund for Peace <http://ffp.statesindex.org/rankings2013-sortable > (accessed 10 March 2014).

Jianan Ge "chaoxian tuobeizhe jiangshu chutao jingji: dongtian dujiang dao zhongguo [North Korean 'Escapees' Tell Their Fleeing Stories: Crossing Rivers to China in Winter]” (24 January 2014) NetEase <http://news.163.com/14/0124/18/9JCGBCKK0001121M_all.html> (accessed 12 February 2014).

Guy S Goodwin-Gill "Convention Relating to the Status of Refugees \& Protocol Relating to the Status of Refugees" UN Audiovisual Library of International Law $<$ http://legal.un.org/avl/ha/prsr/prsr.html> (accessed 28 April 2014).

Guy S Goodwin-Gill “The Refugees Convention: Why not Scrap it?” (2005) Chatham House $<$ https://www.chathamhouse.org/sites/files/chathamhouse/public/Research/International\%20Law /ilp201005.pdf $>$ (accessed 20 June 2013). 
Brian Gorlick "Human Rights and Refugees: Enhancing Protection through International Human Rights Law" (2000) UNHCR New Issues in Refugee Research Working Paper No. 30 $<$ http://www.unhcr.org/3ae6a0cf4.html> (accessed 1 September 2014).

Government of Hong Kong "Commencement of unified screening mechanism for claims for non-refoulement protection" (7 February 2014), available at Hong Kong Government Information Web <http:/www.info.gov.hk/gia/general/201402/07/P201402070307.htm> (accessed 16 April 2014).

Claudia He and Zhao Lin "China is not ready for refugees" (15 September 2009) The Interpreter $<$ http://www.lowyinterpreter.org/post/2009/09/15/China-is-not-ready-for-refugees.aspx> (accessed 1 September 2014).

Kato Hiroshi “China May Recognize Some NK Refugees” (15 March 2009) Life Funds for North Korean Refugees <http://www.northkoreanrefugees.com/2009-03-china-change.htm> (accessed 29 August 2014).

Oliver Hotham "Work visas for North Koreans going to China up 17.2\%" (21 January 2014) NK News <http://www.nknews.org/2014/01/work-visas-for-north-koreans-going-to-china-up-17-2/> (accessed 8 April 2014).

Human Rights Watch "Isolated in Yunnan: Kachin Refugees from Burma in China's Yunnan Province" (June Human 2012) Rights Watch $<$ http://www.hrw.org/sites/default/files/reports/china0612_forinsertForUpload.pdf $>$ (accessed 28 April 2014).

Human Rights Watch (Dinah PoKempner, Tae-Ung Baik and Mike Jendrzejczyk) "The Invisible Exodus: North Koreans in the People's Republic of China” (November 2002) Human Rights Watch < www.hrw.org/reports/2002/northkorea/norkor1102.pdf > (accessed 1 September 2014).

Human Rights Watch “World Report 2012: China” (2012) HRW <http://www.hrw.org/worldreport-2012/world-report-2012-china> (accessed 15 August 2013).

International Detention Coalition "Annual Report 2013" (2013) International Detention Coalition $<$ http://idcoalition.org/publications/2013-annual-report/> (accessed 25 April 2014). 
Terril Yue Jones “China Warns U.N. against 'Irresponsible Remarks' on North Koreans” (3 June 2013) Reuter $\quad<$ http://www.reuters.com/article/2013/06/03/us-korea-north-chinaidUSBRE95209W20130603> (accessed 23 April 2014).

Korea Institute for National Unification "White Paper on Human Rights in North Korea" (1998) $\begin{array}{llll}\text { Korea Institute } & \text { for } & \text { National }\end{array}$ $<$ http://www.kinu.or.kr/eng/pub/pub_04_01.jsp?page=2\&num=6\&mode=view\&field $=\&$ text $=\& 0$ rder $=\& \operatorname{dir}=\& b i d=$ DATA04\&ses $=>($ accessed 4 September 2014$)$

Jasmin Lam “China’s Refugee Policy in Comparison” (25 Aug 2013) E-International Relations Students <http://www.e-ir.info/2013/08/25/chinas-refugee-policy-in-comparison/> (accessed 3 September 2014).

Hansen Li (ed) "jiena guoji nanmin: chuyu liyi, yuanyu daoyi [Acceptance of International Refugees: out of Interest, Originated in Humanity]" (27 February 2012) China Network Television $<$ http://news.cntv.cn/special/thinkagain/refugee/index.shtml $>$ (accessed 28 April 2014).

Dong Li "jiemi zhongchao bianjing wanglaizhe: chuanyue shengsi [Deciphering Border Crossers on the Chinese-North Korean Border: Going between Life and Death" (30 June 2009) China Net <http://www.china.com.cn/news/txt/2009-06/30/content_18036076_2.htm> (accessed 27 April 2014); interview conducted by the author (April 2013).

Daming Li et al 'zhonghan yin 'tuobeizhe' gekong duizhi [Tension between China and South Korea Due to 'North Korean Escapees']" (23 February 2012) Xinhua $<$ http://news.xinhuanet.com/world/2012-02/23/c_122744929.htm> (accessed 20 June 2012).

Lan Lin "Beijing zanting qianfan chaoxian nanmin (Beijing Suspended Repatriation of North Korean Refugees)" (18 April 2012) Radio France International $<$ http://www.chinese.rfi.fr/\%E4\%B8\%AD\%E5\%9B\%BD/20120418\%Е5\%8C \%97\%E4\%BA\%AC\%E6\%9A \%82\%E5\%81\%9C\%Е9\%81\%A3\%E8\%BF\%94\%E6\%9 C\%9D\%E9\%B2\%9C\%E9\%9A\%BE\%E6\%B0\%91> (accessed 28 April 2014).

Jun Liu "30,000 ming guogan nanmin tashang miandian guitu [30,000 Kokang Refugees on Their Way Home]" (16 September 2009) China Weekly $<$ http://www.chinaweekly.cn/bencandy.php?fid=60\&id=4491> (accessed 14 September 2011). 
Yibin Liu “zhou zongli waijiao jingcai shoubi: yinni 'jiusanling shijian' fashenghou [Excellent Diplomatic Work of Prime Minister Zhou: After Indonesia's 'September 30 Incident']” Xinhua Net $<$ www. xinhuanet.com $>$.

Guofu Liu "zhongguo weilai raobuguo nanmin yiti [China Cannot Avoid Refugee Issues in the Future]" (23 February 2012) Xinhua Net <http://news.xinhuanet.com/world/201202/23/c_122744895.htm> (accessed 28 April 2014).

Rhoda Margesson, Emma Chanlett-Avery and Andorra Bruno "North Korean Refugees in China and Human Rights Issues: International Response and U.S. Policy Options" (26 Spetember 2007), United States Congressional Research Service Report for Congress $<$ https://www.fas.org/sgp/crs/row/RL34189.pdf $>$ (accessed 28 April 2014).

Penelope Mathew and Tristan Harley "Refugee Protection and Regional Cooperation in Southeast Asia: A Fieldwork Report" (March 2014) $<$ https://digitalcollections.anu.edu.au/bitstream/1885/11662/1/Mathew\%20\%26\%20Harley\%20 Refugee\%20protection\%202014.pdf >(accessed 4 September 2014).

Jeewon Min "Surrogate Protection in Canada and Potential Nationality in South Korea: Does a North Korean Asylum-Seeker Have a 'Genuine Link' to South Korea?' (2013) CARFMS $<$ http://carfms.org/sites/default/files/North\%20Korean\%20Refugee\%20Status\%20In\%20Canada \%202013\%20Essay\%20Contest\%20CARFMS\%20web.pdf > (accessed 12 February 2014).

MOUonekorea "Exploring the Connection between China and North Korea: Seoul Train Part 1" (20 January 2012) One Korea <https://mouonekorea.wordpress.com/2012/01/20/exploring-theconnection-between-china-and-north-korea-seoul-train-part-1/\#more-899> (accessed 17 March 2014).

Shan Nan "Beijing chaichu yingdi qianfan guogan nanmin [Beijing removed camps and repatriated Kokang Refugees]" (1 September 2009) Asia News <http://www.asianews.it/newszh/\%E5\%8C\%97\%E4\%BA\%AC\%E6\%8B\%86\%E9\%99\%A4\%E8\%90\%A5\%E5\%9C\%B0\%Е9 \%81\%A3\%Е8\%BF\%94\%E6\%9E\%9C\%E6\%95\%A2\%E9\%9A\%BE\%E6\%B0\%91-16205.html> (accessed 13 September 2011).

Nang Mya Nadi and Naw Noreen “Aid Shortage Hits Kachin Refugees” (19 April 2014) Democratic Voice of Burma <http://www.dvb.no/news/aid-shortage-hits-kachin-refugeesburma-myanmar/39734> (accessed 10 September 2014). 
Stephanie Nebehay "China Deports Refugees Ahead of Olympics: U.N." (8 April 2008) Reuters $<$ http://www.reuters.com/article/2008/04/08/us-china-un-refugees-idUSL086328120080408> (accessed 18 April 2014).

Guang Pan "Shanghai: a Haven for Holocaust Victims" United Nations $<$ http://www.un.org/en/holocaustremembrance/docs/paper15.shtml> (accessed 28 April 2014).

Santhosh Persaud "Protecting Refugees and Asylum Seekers under the International Covenant on Civil and Political Rights" (2006) UNHCR New Issues in Refugee Research Working Paper No. $132<$ www.unhcr.org/4552f0d82.html> (accessed 14 September 2014).

Jianyi Piao and Zhipei Li “chaoxian 'tuobeizhe' wenti de guojihua yanbian jiqi yingxiang [The Internationalization of the issue of North Korean 'Escapees' and Its Influence]” (13 August 2012) China Network for the Asian-Pacific Research < http://iaps.cass.cn/news/523644.htm> (accessed 15 August 2013).

Piaobotanggula "guogan, jinye wumian weini qidao [Kokang, Praying for You in This Sleepless Night]" (28 August 2009) Tianya Forum <http://bbs.tianya.cn/post-news-141112-1.shtml> (accessed 14 February 2014).

Tomas Ojea Quintana "Statement of the Special Rapporteur on the Situation of Human Rights in Myanmar" (21 August 2011) Reliefweb <http://reliefweb.int/report/myanmar/statement-specialrapporteur-situation-human-rights-myanmar-3> (accessed 20 August 2014).

Refugee International "Act of Betrayal: the Challenge of Protecting North Koreans in China" (April 2005) Refworld <http://www.refworld.org/docid/47a6eba50.html > (accessed 29 August 2014).

Olivier Rukundo "China's New Exit-Entry Law” (1 October 2012) Fahamu Refugee Legal Aid Newsletter $<$ http://frlan.tumblr.com/post/32664470835/chinas-new-exit-entry-law $>$ (accessed 19 April 2014).

Yan Naing Saw "Kachin Conflict Sparks Refugee Situation" (15 June 2011) The Irrawaddy $<$ http://www2.irrawaddy.org/article.php?art_id=21495> (accessed 28 April 2014).

Sonya Sceats and Shaun Breslin "China and the International Human Rights System" (October 2012)

Chatham House $<$ http://www.chathamhouse.org/sites/default/files/public/Research/International\%20Law/r1012 sceatsbreslin.pdf $>$ (accessed 28 April 2014)

SCIO "Yunnan itng zhengfu jiu dangqian zhongmian bianjing jushi juxing xinwen fabuhui [Yunnan Government Holds Press Conference on Situation on China-Myanmar Border]" (31 August 2009) SCIO $<$ http://www.scio.gov.cn/xwfbh/gssxwfbh/xwfbh/yunnan/200908/t398584.htm> (accessed 28 April 2014). 
SCIO “2012 zhongguo renquan shiye de jinzhan [2012 Progress of Human Rights in China]” (14 May 2012) Xinhua <http://news.xinhuanet.com/politics/2013-05/14/c_115758619.htm> (accessed 28 April 2014).

James D Seymour "China: Background Paper on the Situation of North Koreans in China" (2005) Refworld $<$ http://www.refworld.org/docid/4231d11d4.html $>$ (accessed 28 April 2014) at 15.

Jing Song "Vietnamese refugees well settled in China, await citizenship" (10 May 2007) UNHCR < http://www.unhcr.org/464302994.html > (accessed 28 April 2014).

Mark Stone "N Korean Defectors Held on Laos Border" (15 August 2014) Sky News $<$ http://news.sky.com/story/1317909/n-korean-defectors-held-on-laos-border $>\quad$ (accessed 20 August 2014).

Hiroyuki Tanaka "North Korea: Understanding Migration to and from a Closed Country" (7 January 2008) Migration Policy Institute <http://www.migrationpolicy.org/article/north-koreaunderstanding-migration-and-closed-country $>$ (accessed 1 September 2014).

Duanfang Tao "nanmin: zenyang bangzhu guojia de lingju? [Refugees: How to Help Our Country's Neighbours?]" NetEase <http://news.163.com/special/reviews/refugees.html> (accessed 20 April 2014).

UNHCR "UNHCR Regional Representation in China" UNHCR $<$ http://www.unhcr.org.hk/unhcr/en/about_us/China_Office.html $>$ (accessed 28 April 2014).

UNHCR "Note on International Protection" (1 September 1995), A/AC.96/850, at [11]; UNHCR "Interpreting Article 1 of the 1951 Convention relating to the Status of Refugees" (2001), $<$ http://www.unhcr.org/refworld/docid/3b20a3914.html> (accessed 15 July 2012).

UNHCR “China: UNHCR Helping North Koreans" (26 June 2001) UNHCR $<$ http://www.unhcr.org/3b3889530.html> (accessed 20 April 2014).

UNHCR "Seven North Korean Asylum Seekers Arrive in Seoul” (30 June 2001) UNHCR $<$ http://www.unhcr.org/3b4049cb1.html> (accessed 20 April 2014).

UNHCR "UNHCR Seeks Access to North Koreans Detained in China" (21 January 2003) UNHCR <http://www.unhcr.org/3e2d81b94.html> (accessed 28 April 2014).

UNHCR "Self-Study Module 1: An Introduction to International Protection. Protecting Persons of Concern to UNHCR" (1 August 2005) UNHCR $<$ http://www.unhcr.org/publ/PUBL/3ae6bd5a0.pdf > (accessed 28 April 2014). 
UNHCR "Self-Study Module 2: Refugee Status Determination: Identifying Who is a Refugee" (1 September 2005) UNHCR <http://www.unhcr.org/pub1/PUBL/43144dc52.pdf> (accessed 28 April 2014).

UNHCR "Fair and Efficient Asylum Procedures: A Non-Exhaustive Overview of Applicable International Standards" (2 September 2005) Refworld $<$ http://www.refworld.org/docid/432ae9204.html> (accessed 1 September 2014).

UNHCR "China: Concerns over Deportation" (8 April 2008) UNHCR $<$ http://www.unhcr.org/47fb4ed42.html> (accessed 18 April 2014).

UNHCR "China: UNHCR Calls for Access to Myanmar Refugees" (4 September 2009) UNHCR < http://www.unhcr.org/4aa108159.html> (accessed 28 April 2014).

UNHCR "Introductory Note to the Convention and Protocol relating to the Status of Refugees" (2011) UNHCR <www.unhcr.org/3b66c2aa10.pdf> (accessed 16 October 2014).

UNHCR "UNHCR Reaches Kachins Sent back from China" (7 September 2012) UNHCR $<$ http://www.unhcr.org/5049cdba9.html> (accessed 28 April 2014).

UNHCR "How UNHCR is Run and Structured" UNHCR $<$ http://www.unhcr.org/pages/49c3646c80.html> (accessed 28 April 2014).

UNHCR "Submission by the United Nations High Commissioner for Refugees For the Office of the High Commissioner for Human Rights' Compilation Report - Universal Periodic Review: People's Republic of China" (March 2013), Refworld $<$ http://www.refworld.org/pdfid/5135b0cb2.pdf > (accessed 28 April 2014).

UNHCR "Procedural Standards for Refugee Status Determination under UNHCR's Mandate" (2003) UNHCR <http://www.unhcr.org/4317223c9.html > (accessed 28 April 2014).

UNHCR Regional Representation for China and Mongolia "Fact Sheet" (March 2014) UNHCR $<$ http://www.unhcr.org/5000187d9.html> (accessed 28 April 2014).

UNHCR "EXCOM Membership by Admission of Members" UNHCR $<$ http://www.unhcr.org/40112e984.html> (accessed 17 April 2014).

UNHCR Bureau for Asia and the Pacific "Regional Update" (March 2014) UNHCR $<$ http://www.unhcr.org/5000139a9.pdf> (accessed 23 April 2014).

UNHCR "2013 Regional Operations Profile - East Asia and the Pacific" UNHCR $<$ http://www.unhcr.org/ pages/49e45b276.html> (accessed 14 July 2013).

UNHCR "Unified Screening Mechanism" (26 March 2014) UNHCR $<$ http://www.unhcr.org.hk/unhcr/en/news_and_updates/news_list/news_details.html?id=1115> (accessed 16 April 2014).

UNHCR "Hong Kong (Special Administrative Region of China) Statistical Snapshot" (2014) $<$ http://www.unhcr.org/cgi-bin/texis/vtx/page?page=49e488026\#> (accessed 7 April 2014). 
UNHCR "Government Contributions to UNHCR" (2014) UNHCR <http://www.unhcr.org/cgibin/texis/vtx/page?page $=49 \mathrm{e} 487 \mathrm{~cd} 6 \&$ submit $=\mathrm{GO}>$ (accessed 23 April 2014).

USCRI "U.S. Committee for Refugees World Refugee Survey 1999 - China, (including Hong Kong and Tibet)" (1999), USCRI <http://www.refworld.org/docid/3ae6a8a61f.html> (accessed 27 April 2014).

USCRI "U.S. Committee for Refugees World Refugee Survey 2002 - China (Including Tibet)" (10 June 2002) Refworld < http://www.refworld.org/docid/3d04c14c10.html $>$ (accessed 25 April 2014).

USCRI "World Refugee Survey" (2009) USCRI <http://www.refugees.org/resources/refugeewarehousing/archived-world-refugee-surveys/2009-wrs-country-updates/china.html> (accessed 28 April 2014).

Zheng Wang "zhongguo zhengfu gei ruantingyin zhengzhi bihu li [Example of Asylum: Asylum granted by Chinese Government to Ruan Tingying]" China-ASEAN Law <www. zgdmlaw.com>.

Jianfeng Wei "xinzhongguo guiqiao xuesheng jiaoyu wenti shuyao [Summary of the Education of Returning Overseas Chinese Students in New China]" (25 April 2011) Guangdong Overseas Chinese Web (Guangdong Province People's Government Office for Overseas Chinese affairs) $<$ http://gocn.southen.com/qwyj/201104/t20110425_155249.htm> (accessed 28 April 2014).

Xiaoqing Zhu "guoji tiaoyue zai zhongguo guonei de shiyong yanjiu [Study on Application of International Treaties in China]" (20 June 2001) Bureau of International Cooperation of China Academy of Social Science $<$ http://bic.cass.cn/info/Arcitle_Show_Study_Show.asp?ID $=2257 \&$ Title $=\%$ B9\%FA $\%$ BC $\%$ CA $\%$ CC\%F5\%D4\%BC\%D4\%DA\%D6\%D0\%B9\%FA\%B9\%FA\%C4\%DA\%B5\%C4\%CA\%CA\%D $3 \% \mathrm{C} 3 \% \mathrm{D} 1 \% \mathrm{D} 0 \% \mathrm{BE} \% \mathrm{BF} \&$ strNavigation $=\% \mathrm{CA} \% \mathrm{D} 7 \% \mathrm{D} 2 \% \mathrm{~B} 3-$ $\% 3 \mathrm{E} \% \mathrm{BF} \% \mathrm{BC} \% \mathrm{~B} 2 \% \mathrm{EC} \% \mathrm{D} 1 \% \mathrm{D} 0 \% \mathrm{BE} \% \mathrm{BF}-\% 3 \mathrm{E} \% \mathrm{CE} \% \mathrm{C} 4 \% \mathrm{BB} \% \mathrm{AF}>\quad$ (accessed 22 September 2011).

\section{J Newspaper and Magazine Articles}

"A Hypocritical, Hollow Critique" The Australian (online ed, 22 February 2014) $<$ http://www.theaustralian.com.au/opinion/editorials/a-hypocritical-hollow-critique/storye6frg71x-1226834198413?nk=435b3b55a6999c3aea51f56645fd3005> (accessed 20 March 2014).

"China Compelled to Terminate Economic and Technical Aid to Viet Nam" (14 July 1978) 28 Beijing Review 27. 
“China Gives Work Visas for 20,000 N.Koreans" The Chosunilbo (online ed, Seoul, 28 May 2012).

"wo youguan bumen genju zhongguo falü guiding yunxu qiaoqinglu deng shiren zai woguo juliu [Chinese Governing Department Allowed Ten Persons including Qiao Qinglu to Reside in China according to Chinese Legal Provisions]" Remin Ribao (China, 16 October 1981).

“Why Lai Changxing's Appeal to Canadian Court Rejected?” People’s Daily (online ed, Beijing, 9 February 2004).

Jamil Anderlini "China presses Thailand to return Uighur refugees" Financial Times (Online ed, 3 April 2014), available at <http:/www.ft.com/intl/cms/s/0/35bbf33a-bb1d-11e3-948c00144feabdc0.html\#axzz3I4pBroPA > (accessed 20 June 2014).

Yinghong Cheng "magong zongshuji Chen Ping de chuanqi rensheng [The Legendary Life of the Former Secretary General of the Malayan Communist Party, Chen Ping]" Phoenix Weekly (online ed, Hong Kong, 16 October 2013).

Buzhi Ding, Zhen Xu and Jialin Liang "yige yi cunzai 30 nian de chenmo qunti: 30 wan nanmin zai zhongguo [A Silent Community that Have Existed for 30 Years: 300 Thousand Refugees in China]" (2009) Nanfang zhoumo (Southern Weekly) (online ed, Guangzhou, 15 Oct 2009).

$\mathrm{Bi} \mathrm{Hu}$ "ruhe jie 'nanmin' zhedao ti [How to Solve the Problem of 'Refugees']" Southern Weekly (online ed, Guangzhou, 3 September 2009).

Michael Jendrzejczyk “A Refugee Travesty: From Eating Rats in North Korea to Sex Abuse in China” The New York Times (online ed, New York, 19 November 2002).

Xiaokun Li "China Issues 20,000 Work Visas to DPRK" China Daily (online ed, China, 28 May 2008), available at <http://usa.chinadaily.com.cn/world/2012-05/28/content_15404632.htm> (accessed 29 August 2014).

Meilian Lin "Home away from home" Global Times (online ed, China, 22 December 2013).

Jay Mathews "Refugees Worry South China: Thousands of Refugees from Vietnam Produce Uneasiness in South China" The Washington Post (Washington, 16 July 1978) at A18.

Chaozhi Peng "laowo nanmin daqianfan (Repatriation of the Lao Refugees)" shidai fengcai [Modern Elegance] (China, October 1994) at 40.

Renmin Ribao commentator "Lies Cannot Cover up Facts" (16 June 1978) 24 Beijing Review 17. 
Elisabeth Rosenthal "North Koreans Get Asylum at Beijing Embassies" The New York Times (online ed, New York, 27 April 2002).

Xiao Shao "Shenghuo zai zhongguo de waiguo nanmin [Foreign Refugees Living in China]" Baixing [Ordinary People] (China, March 2004) at 50.

Spokesman of the Overseas Chinese Affairs Office of the State Council "Statement on Viet Nam's Expulsion of Chinese Residents" (2 June 1978) 22 Beijing Review 14.

United States Congressional-Executive Commission on China "2013 Annual Report" (10 October 2013), United States Congressional-Executive Commission on China $<$ http://www.cecc.gov/publications/annual-reports/2013-annual-report $>$ (accessed 28 April 2014).

United States Congressional-Executive Commission on China "The Rising Stakes of Refugee Issues in China" (1 May 2009), United States Congressional-Executive Commission on China $<$ http://www.cecc.gov/events/roundtables/the-rising-stakes-of-refugee-issues-in-china $>$ (accessed 29 August 2014).

Jing Wan "nanmin wenti yizhi zai fasheng, bushi zhe jiushi na [Refugee Problems always happen, either here or elsewhere]" Southern Weekly (online ed, China, 8 July 2011).

Edward Wong and Patrick Zou "Chinese Deny Forcing Refugees to Myanmar" The New York Times (online ed, New York, 25 August 2012).

Hongwei Ying "Guogan jiannan rongru miandian (Kokang Painfully Integrate into Myanmar)" Time Weekly (online ed, China, 17 Jan 2013).

Li Zhang "Ta zenyang maoxian laidao zhongguo - fangwen yuenan ganbu ruantingyin [How He Risked to Come to China-Interview with VietnameseOfficer Ruan Tingyin]" Remin Ribao (China, 2 December 1978).

Jing Zhang "Zhongguo weishenme bushe nanminying [Why China Did Not Establish Refugee Camps]" Zhongguo shehui daokan [China Society] (China, May 2002) at 58.

Xiong Zhang "guogan nanmin zai zhongguo [Kokang Refugee in China]" xinshiji zhoukan [Century Weekly] (online ed, China, 28 September 2009) at 28.

Yinan Zhao "Legal Status for Seekers of Asylum" (2012) China Daily (online ed, China, 2 July 2012).

\section{K Speeches}

Erika Feller, Assistant High Commissioner - Protection, UNHCR "Humanitarian Space" (Oxford, 22 September 2009), available at <http://www.unhcr.org/4ad49ed29.pdf $>$ (accessed 1 September 2014). 
Yafei He, Ambassador, Permanent Representative of PRC to the United Nations Office at Geneva and Other International Organizations in Switzerland "Statement on the $61^{\text {st }}$ UNHCR Excom" (Geneva, 4 October 2010).

Yafei He, Chinese Ambassador to UN, Statement at the intergovernmental event at the ministerial-level of Member States of the United Nations to commemorate the 60th anniversary of the 1951 Convention relating to the Status of Refugees and the 50th anniversary of the 1961 Convention on the Reduction of Statelessness (Geneva, 9 December 2011).

Prince Sadruddin Aga Khan "Oral Statement of Prince Sadruddin Aga Khan, United Nations High Commissioner for Refugees, to UNHCR headquarters staff on 1 February 1972" (Geneva, 1 February 1972), available at UNHCR <http://www.unhcr.org/3ae68fb314.html > (accessed 20 August 2014).

Cheng Luo, Chinese Delegate to the UN "Statement at the Third Committee of the 64th Session of the UN General Assembly on Refugees” (New York, 3 November 2009).

Sadako Ogata, United Nations High Commissioner for Refugees "Statement at the intergovernmental consultations on asylum, refugee and migration policies in Europe, North America and Australia" (Washington DC, May 1997).

Guangya Wang, Vice Foreign Minister of the People's Republic of China "Statement at the Ministerial Meeting of States Parties to the 1951 Convention Relating to the Status of Refugees” (Geneva, 12 December 2001).

Guangya Wang, Vice Foreign Minister of PRC "Remarks at the Opening Ceremony of The Third APC Mekong Sub-regional Meeting on Refugees, Displaced Persons and Migrants" (Beijing, 26 August 2002).

Guixuan Zhang, Chinese Delegate to the UN "Statement at the Third Committee of the 67th Session of the UN General Assembly on Refugees” (New York, 7 November 2012).

\section{Other Resources}

Border Girl, Fu Chen and Gui Chen (dirs) (independent documentary, 2012).

MFA press conferences, Beijing, 19 March 2002, 5 September 2002, 7 January 2003, 16 January 2003, 17 February 2004, 27 April 2004, 11 October 2005, 7 December 2006, 23 January 2007, 25 December 2007, 22 January 2008, 22 February 2008, 1 September 2009, 16 June 2011, 22 February 2012, 28 February 2012. 
Bonaventure Rutinwa "Prima Facie Status and Refugee Protection" (2001) UNHCR New Issues in Refugee Research Working Paper No 69.

Vanessa Holzer "The 1951 Refugee Convention and the Protection of People Fleeing Armed Conflict and Other Situations of Violence" (September 2012) UNHCR Legal and Protection Policy Series, PPLA/2012/05, available at <http://www.refworld.org/docid/50474f062.html> (accessed 8 September 2014).

The Inter-Governmental Asia-Pacific Consultation on Refugees, Displaced Persons and Migrants “Chair's Summary” (Eleventh Plenary Session, Xiamen, 23-25 November 2006). 